RENATA DE PAULA OROFINO SILVA

Análise da argumentação e de seus processos formadores em uma aula de Biologia 


\title{
Análise da argumentação e de seus processos formadores em uma aula de Biologia
}

\author{
Dissertação apresentada ao \\ Instituto de Física, ao Instituto de \\ Química, ao Instituto de Biociências e à \\ Faculdade de Educação da \\ Universidade de São Paulo, para a \\ obtenção do título de Mestre em Ciências.
}

Área de concentração: Ensino de Biologia

Orientadora: Prof. $\underline{\text { D }}$. $\underline{\text { a }}$ Sílvia Luzia Frateschi Trivelato 
Autorizo a reprodução e divulgação total ou parcial deste trabalho, por qualquer meio convencional ou eletrônico, para fins de estudo e pesquisa, desde que citada a fonte.

FICHA CATALOGRÁFICA

Preparada pelo Serviço de Biblioteca e Informação do Instituto de Física da Universidade de São Paulo

Orofino, Renata de Paula

Análise da argumentação e de seus processos

formadores em uma aula de Biologia - São Paulo, 2011.

Dissertação (Mestrado) - Universidade de São Paulo.

Faculdade de Educação, Instituto de Física, Instituto de

Química e Instituto de Biociências.

Orientador: Profa. Dra. Silvia Luzia Frateschi Trivelato

Área de Concentração: Biologia

Unitermos: 1. Biologia - Estudo e ensino; 2. Métodos de ensino; 3. Linguagem científica; 4. Ensino

e aprendizagem; 5 . Ensino médio. 
Nome: OROFINO, Renata de Paula

Título: Análise da argumentação e de seus processos formadores em uma aula de Biologia

Dissertação apresentada ao

Instituto de Física, ao Instituto de Química, ao Instituto de Biociências e à

Faculdade de Educação da

Universidade de São Paulo, para a obtenção

do título de Mestre em Ciências.

Aprovado em:

Banca examinadora

Prof. Dr.: Instituição:

Julgamento: Assinatura:

Prof. Dr.: Instituição:

Julgamento: Assinatura:

Prof. Dr.: Instituição:

Julgamento: Assinatura: 


\section{Agradecimentos}

Agradeço primeiramente à minha orientadora, pela liberdade de criação, pela confiança, por estar sempre presente e por ser brilhante profissional e pessoalmente.

Aos colegas de laboratório, integrantes do GEPEB, por me fazerem crescer profissionalmente e pelos ótimos momentos de descontração.

À Coordenação de Aperfeiçoamento de Pessoal de Nível Superior e Fundação de Amparo à Pesquisa do Estado de São Paulo, pelo apoio financeiro.

Aos professores de disciplinas e de monitorias que contribuíram em diferentes aspectos para a minha formação.

Aos funcionários da Secretaria de Pós-graduação Interunidades em Ensino de Ciências, por salvarem a minha pele uma dezena de vezes, sempre muito solícitos e pacientes.

Às amigas mais próximas: Sarah, que eu só conheci no mestrado, mas que convive tanto comigo que é quase inseparável; Roberta, Marília, Fer e Vivi, que me aturaram nos momentos de péssimo humor no decorrer desses dois anos e sempre estavam lá pra me apoiar ou me dar broncas quando era necessário; Julinha e Jundi, que mesmo mais distantes sempre serão muito queridas.

Aos amigos da Bio, pelas horas de descontração e diversão. Amigos que reconquistei depois de me tornar uma pessoa mais sociável.

Ao Rafael Gonçalves, à Daniela Scarpa e à Escola de Aplicação, por fazerem a sequência didática ser viável. Sem vocês nada disso estaria escrito.

Ao Guguinho, Julinha e Maroca que revisaram o texto com muito amor e carinho.

Ao time de handebol que garantiu minha sanidade mental durante esses dois anos além das risadas e emoções compartilhadas.

À minha família por me aturar em casa até hoje, pelo amor e compreensão.

Finalmente, ao Rodrigo. Sempre ao meu lado, inteligente, divertido e especial. Se um dia eu for metade do que você é profissionalmente já estarei feliz. 


\section{Resumo}

OROFINO, R.P. Análise da argumentação e de seus processos formadores em uma aula de Biologia. 2011. 186 f. Dissertação (Mestrado) - Instituto de Física, Universidade de São Paulo, São Paulo, 2011.

Dentre os diversos elementos que compõem a alfabetização científica, este trabalho se fixa sobre a argumentação em uma aula de genética. Analisamos uma sequência de três aulas de Biologia para o 3o ano do Ensino Médio para identificar e classificar argumentos científicos fornecidos em aula pela professora e pelo material didático bem como argumentos escritos produzidos pelos alunos sobre a função do DNA nos seres vivos. Analisamos os dados tomando como base o trabalho de Simon, Erduran e Osborne (2006) e Toulmin (2006). As análises apontaram para a existência de ações próargumentação da professora durante as aulas teórico-explicativas. Os argumentos fornecidos pela professora e pelo texto base foram considerados simples e embasados apenas em dados, ao invés de usarem também garantias e apoios. A questão proposta pela professora foi compreendida por 30 dos 35 alunos da amostra. Aproximadamente metade da amostra apresentou alguma justificativa para suas conclusões e a maioria dos argumentos foi considerada válida. Porém, apenas sete alunos conseguiram responder a questão utilizando todos os conceitos que deveriam, enquanto a maioria dos alunos usou apenas parte dos conceitos exigidos ou apresentou conceitos errados na tentativa de responder a questão. Fica o indício de que práticas comuns de sala de aula podem ser modificadas de forma a estimularem a argumentação dos alunos em aulas de ciências.

Palavras chave: educação, métodos de ensino, linguagem científica. 


\section{Abstract}

OROFINO, R.P. Argumentation and its processes in biological classes. 2011. 186 f. Dissertação (Mestrado) - Instituto de Física, Universidade de São Paulo, São Paulo, 2011.

Among the several elements of scientific literacy this study attempted to analyze argumentation in a Genetic class. Three Biology classes (15-17 years) were audio and video recorded and analyzed to identify the arguments present in the teacher's speech and also in the text given by the teacher. Students' argumentation about DNA's function in live organisms was also analyzed. To assess teacher's oral contribution to argumentation we used Simon, Erduran and Osborne (2006) research method, and to analyze the students' and teacher's argumentation we used Toulmin's argument pattern (TAP). We have identified that the teacher's speech represents oral contribution to the students' argumentation. The text given by the teacher and the teacher's arguments are poor, using mostly data to justify their claims, instead of using also warrants and backings. The task suggested by the teacher was well understood by 30 out of 35 students, almost all of them used scientifically valid arguments and more than half of the sample justified their conclusions. However, only seven of them were able to answer the question using all the content required. Most of the students failed to mention all the required information or presented misconceptions in their answers. Our work demonstrates that different pedagogical strategies may be useful to develop scientific argumentation among students.

Keywords: education, education methods, scientific language. 


\section{Sumário}

APRESENTACÃ

1- INTRODUCẼ̃O

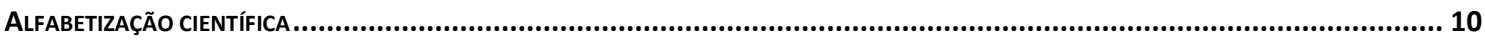

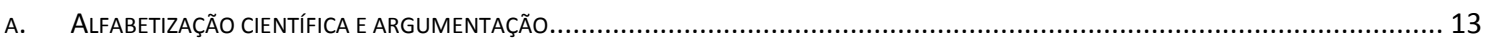

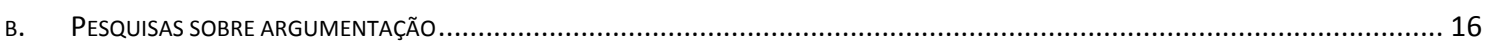

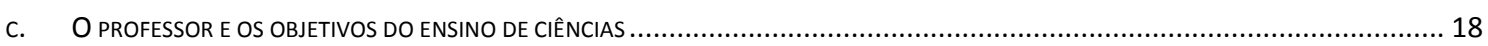

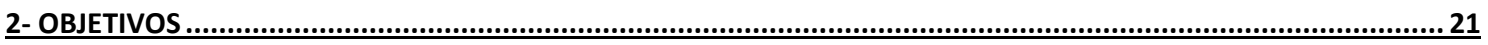

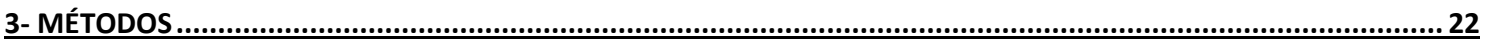

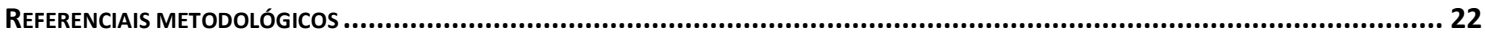

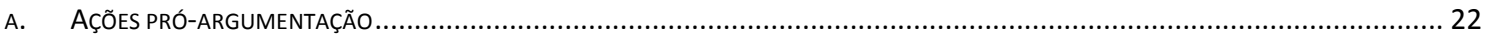

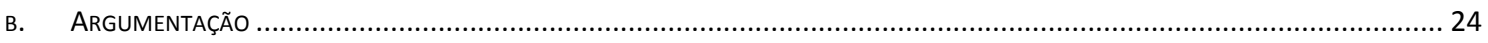

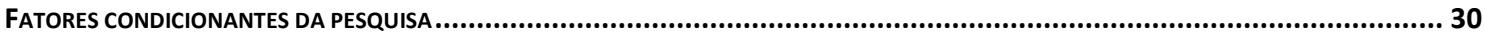

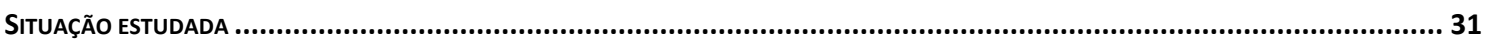

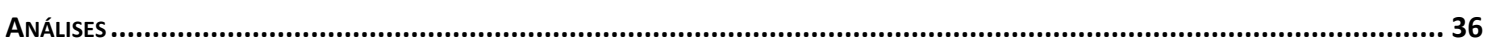

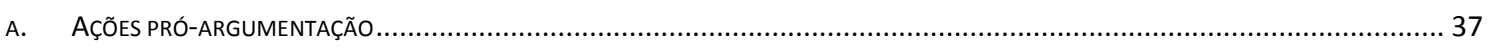

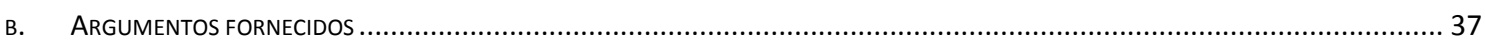

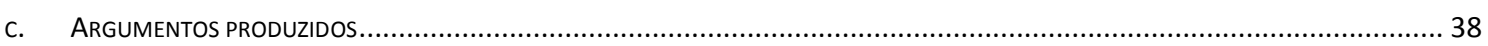

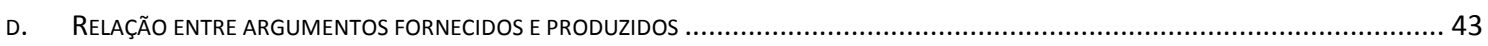

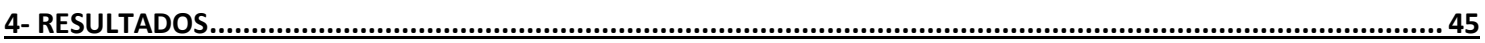

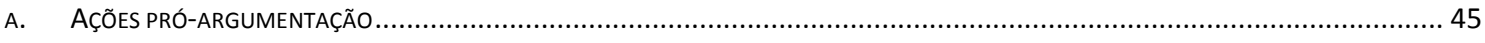

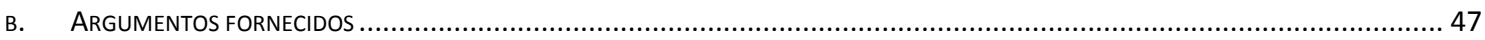

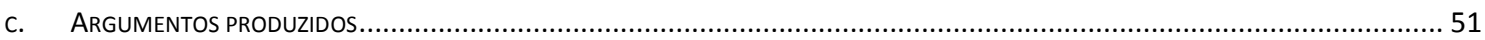

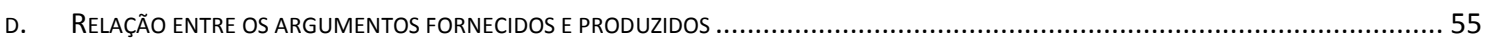

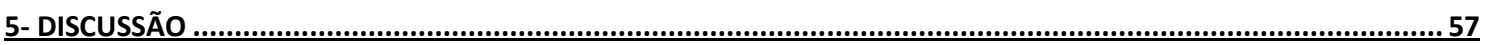

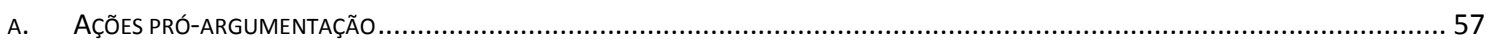

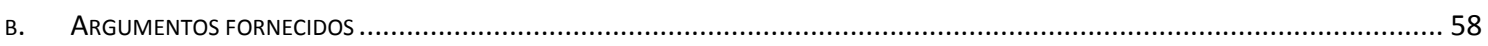

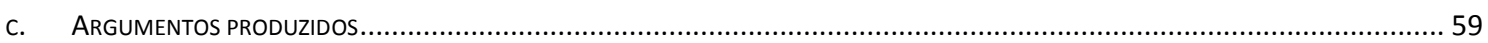

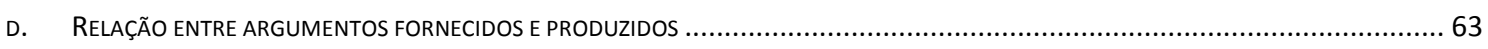

6- CONCLUSÃO

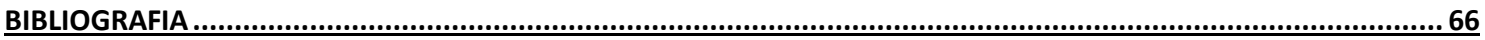

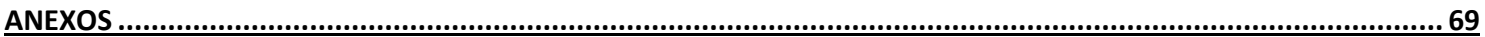

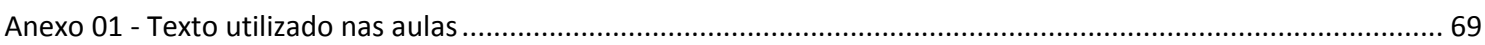

Anexo 02 - Questão proposta pela professora e respostas dos alunos (originais e argumentos) .............................. 72

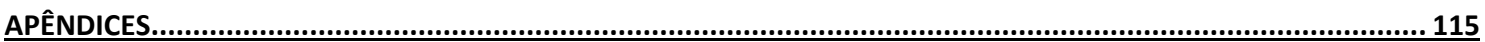

Apêndice 01 - Análises dos argumentos produzidos pelos alunos ....................................................... 115

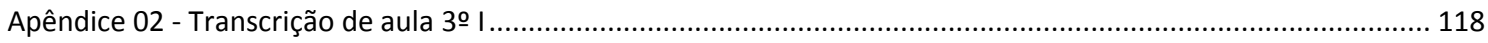

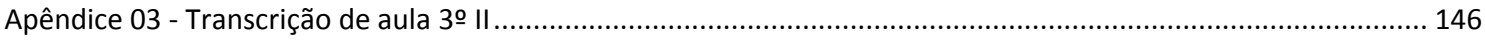

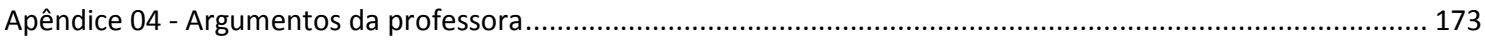

Apêndice 05 - Relação entre argumentos fornecidos e produzidos................................................................. 185 


\section{Apresentação}

Este trabalho se encerra quase três anos após as filmagens de duas turmas de $3^{\circ}$ ano do Ensino Médio. Na época, eu estava planejando um projeto de Iniciação Científica e acompanhava as filmagens como apoio técnico ao colega de laboratório que registrava uma sequência didática para seu trabalho de mestrado. A professora responsável pelas turmas era também colega de grupo de discussões e estudos. A sequência seria usada também por ela em seu trabalho de doutorado.

Nas segundas e quartas passávamos parte da manhã arrumando materiais e filmando as aulas de Biologia das duas turmas de $3^{\circ}$ ano da Escola de Aplicação. Posicionávamos as câmeras de vídeo e os gravadores pela sala e assistíamos à aula. Ao final de cada aula, recolhíamos os gravadores e nos instalávamos em nosso laboratório para copiar os dados para o computador. As fitas de vídeo eram nosso maior problema, pois não conseguíamos digitalizar diretamente.

Naquele ano utilizei uma das aulas da sequência didática que gravamos como objeto de análise do projeto de Iniciação científica - A argumentação em uma aula prática de Biologia: a estrutura do DNA. Quase um ano depois do término desse trabalho, resolvemos usar essa mesma sequência como objeto de estudo de mais uma pesquisa - a de mestrado.

Os interesses já estavam amadurecidos, tínhamos mais preocupações nos tipo de atividade que poderiam ou não estimular a argumentação dos alunos e queríamos analisar uma sequência bastante simples, a leitura de um texto de forma dialogada. Esse tipo de sequência ocorre com mais frequência em salas de aula do que sequências de investigação, com experimentos ou saídas a campo. Estaríamos tratando, portanto, da realidade da maioria dos professores de Ciências e Biologia.

O foco inicial era identificar se os alunos argumentavam em um exercício escrito ao final da sequência. Analisamos extensamente os argumentos dos alunos. Mas o que no fazer da professora analisada e no planejamento da sequência pode ter servido de estímulo para a argumentação dos alunos? Como a correção conceitual dos alunos pode ser avaliada no exercício proposto? Essas dúvidas nos levaram a analisar outros elementos que compunham a sequência didática. 
A apresentação deste trabalho se pretende linear para facilitar a compreensão dos fatos, apesar do caminho da pesquisa ter sido na ordem inversa. Discutimos inicialmente as ações pró-argumentação da professora, seguido pelos argumentos fornecidos em aula, ambos como possíveis estímulos à argumentação dos alunos. Passamos à análise dos argumentos produzidos pelos alunos, tanto em forma quanto em conteúdo. Por fim, relacionamos os argumentos fornecidos com os produzidos, para identificar semelhanças ou diferenças na utilização das informações pela professora e pelos alunos.

O primeiro capítulo apresenta uma revisão bibliográfica que esperamos dar base para as discussões travadas neste trabalho. Inserimo-nos na área de pesquisas sobre a alfabetização científica e sobre o papel da argumentação no ensino de ciências. Em seguida, sumarizamos nossos objetivos específicos.

No terceiro capítulo apresentamos melhor a situação estudada, as nuances de cada aula, o referencial teórico específico de análise e como foram tratados os registros feitos nas aulas. Explicamos, nesse capítulo, como categorizamos cada grupo de informações registradas para que pudéssemos analisá-los.

O quarto capítulo contém a exposição dos resultados de nossas análises, sumarizados em tabelas e gráficos, acompanhados de explicações que deixam claras as nuances qualitativas de nossas análises. A situação estudada é complexa e entendemos que apenas a quantificação não dá conta de explicitar as análises pretendidas.

No quinto capítulo confrontamos os resultados de nossas análises com os resultados de análises de outros autores em situações diferentes ou similares à estudada. Por fim, resumimos nossas conclusões em um último capítulo que se pretende sucinto, com as breves afirmações que podemos fazer a partir de nossos dados e embasamentos teóricos.

Ao pensarmos esse trabalho como um argumento, o último capítulo apresenta nossa afirmação central e esta é defendida pelos fatos (resultados) e sustentados por nossa revisão bibliográfica e referencial teórico de análise. As discussões com outros autores compõem ora os qualificadores de nosso argumento, dando força à conclusão, ora como refutação para alguma garantia anteriormente exposta.

Esta dissertação apresenta anexos, textos de outra autoria que servem de fundamentação para o trabalho e, em seguida, apresenta apêndices, textos de minha elaboração que complementam minha argumentação. 


\section{1- Introdução}

\section{Alfabetização científica}

A sociedade atual é fruto dos avanços científico-tecnológicos acumulados ao longo do tempo. Os conceitos científicos interferem cotidianamente na vida dos cidadãos, que precisam escolher entre consumir alimentos orgânicos ou transgênicos, decidir sobre a compra de um carro "flex", ou até mesmo votar em plebiscito sobre o uso de células-tronco embrionárias em pesquisas. Pensando nessa influência que a ciência tem sobre o cotidiano das pessoas, a área de Ensino de Ciências começou a defender a alfabetização científica, um novo entendimento de como a ciência deveria ser ensinada. A relevância dessa nova visão sobre o ensino de ciências está na influência que a ciência tem sobre o nosso dia-a-dia, desde a reciclagem do lixo até as mudanças climáticas globais ou ainda a decisão sobre em quais fontes energéticas investir.

Em muitos dos casos, a ciência é tanto fonte causadora, por ser responsável pelos avanços tecnológicos e consequências do uso dos recursos naturais, quanto possível fonte de resolução, por possibilitar criar mitigações a efeitos nocivos ou ainda proporcionar avanços úteis ao uso dos recursos naturais. A sociedade seria a maior beneficiada se os cidadãos fossem capazes de adotar posturas realistas frente às ciências e se usassem esses conhecimentos na resolução dos conflitos diários (ALBE, 2008). As escolhas acerca da ciência e suas consequências envolvem questões éticas e científicas e os cidadãos precisam ser capazes de avaliar a integridade das informações antes de tomar suas decisões (DAWSON e VENVILLE, 2009).

De acordo com a ideia de alfabetização científica (scientific literacy; OCDE, 2007; BYBEE; MCCRAE; LAURIE, 2009), devemos ensinar o conteúdo científico e as outras características que compõem a natureza científica. Esse conhecimento mais global, mais completo da ciência, permitirá ao cidadão que seja mais crítico e que saiba se posicionar frente a questões científicas (KRASILCHIK e MARANDINO, 2007). Ou seja, o indivíduo alfabetizado cientificamente é aquele que tem conhecimentos intelectuais e práticos da ciência, além da compreensão de ideias e valores (DAWSON e VENVILLE, 2009). 
Sob o nome alfabetização científica temos diversas compreensões (NORRIS e PHILLIPS, 2003; DAWSON e VENVILLE, 2009). Algumas pesquisas indicam que alfabetização significa apenas saber ler e escrever enquanto outras pesquisas defendem que um indivíduo alfabetizado em ciências sabe utilizar o conhecimento científico nos momentos necessários, compreende eventos e informações científicas veiculadas no cotidiano e sabe a influência da ciência em sua vida pessoal e social. Essa última interpretação de alfabetização científica seria a almejada no ensino de ciências (HURD, 1998; AULER e DELIZOICOV, 2001; NORRIS e PHILLIPS, 2003; SASSERON e CARVALHO, 2008; SANTOS, 2007; GUTIÉRREZ, 2008).

As pesquisas sobre esse tema ganharam importância entre os anos de 2003 e 2007, identificando a formação científica de futuros cidadãos como um tema cada vez mais investigado (LEE; WU; TSAI, 2009). Vemos uma linha de pesquisa bastante clara e estabelecida, rica em temas a serem tratados em sala de aula (p.ex. a atribuição de significado aos conceitos científicos e sua articulação nos momentos necessários). Esse objetivo tem sido endossado não só por pesquisas sobre Ensino de Ciências, mas também por diferentes currículos ao redor do mundo que têm adaptado essas ideias ao programa de ciências (ALBE, 2008; HENAO e STIPCICH, 2008; CLARK e SAMPSON 2008).

Em língua portuguesa vemos uma diferenciação entre alfabetização e letramento. Muito dessa discussão se baseia em uma obra que caracteriza alfabetizar como ensinar a ler e a escrever, já letrar, caracteriza como tornar letrado, erudito, versado em (SOARES, 1998). Ao ser transportada para a área de ensino de ciências, tal distinção fez nascer o termo letramento científico. O uso desse termo implica em subentender as consequências sociais, culturais, políticas, econômicas, cognitivas e linguísticas da ciência (MAMEDE e ZIMERMANN, 2005).

Além desses dois termos, também encontramos na literatura o termo enculturação científica, igualmente encontrado em língua inglesa (enculturation; DRIVER; NEWTON; OSBORNE, 2000; CAPECCHI; CARVALHO; SILVA, 2002; ERDURAN; SIMON; OSBORNE, 2004; SADLER e FOWLER, 2006; SIMON; ERDURAN; OSBORNE, 2006; MARTIN e HAND, 2009). Tais autores entendem que a ciência é uma cultura diferente da cultura corrente da vida do aluno, sendo assim, ensiná-la envolveria ensinar todos os elementos que compõem tal cultura, um processo de socialização das práticas particulares da ciência (MORTIMER, 1996).

Todos os termos citados acima são guiados por uma ideia central, que o ensino de ciências não pode ser composto apenas dos conceitos prontos, descontextualizados e com 
caráter de verdade incontestável com os quais conta o ensino de ciências atualmente. Existem valores que os estudantes devem ter independente de suas carreiras futuras (DAWSON e VENVILLE, 2009), ou seja, o ensino de ciências deve se preocupar em formar cidadãos mais críticos e participativos nos assuntos de sua sociedade, sejam eles culturais, econômicos ou que envolvam a ciência de alguma forma (McNEILL, 2009). A escola que compartilhe dessas ideias deve promover uma visão mais coerente de ciência, a contextualização de conceitos na vida real, um relato histórico mais verossímil sobre os conceitos construídos, a valorização do papel das evidências na construção da ciência e o uso da linguagem corrente na ciência (NEWTON; DRIVER, OSBORNE, 1999).

Escolhemos usar neste trabalho o termo alfabetização científica em detrimento dos outros termos possíveis. Segundo Krasilchik e Marandino (2007) as congruências entre as diferentes linhas de pensamento podem sim ser colocadas sob o nome alfabetização, basta deixarmos de entender a alfabetização apenas como saber ler e escrever. 0 termo, discutido também na alfabetização em línguas, é abrangente e engloba as ideias centrais que pretendemos defender.

Enquanto, de um lado, a recomendação de como o ensino deveria ser cresce no sentido da alfabetização científica, de outro, trabalhos atuais ainda atestam um ensino de ciências distante desses objetivos, estanque e limitado aos conhecimentos conceituais estabelecidos pela ciência ao longo dos séculos (CARVALHO, 2004; MUNFORD e LIMA, 2009). Resta-nos a dúvida sobre o sentido da manutenção do modo dogmático de ensinar ciências, uma escola com uma quantidade muito grande de informações e de conceitos estanques que só se mantém na cabeça dos alunos até a hora da prova (CAZELLI e FRANCO, 2001).

Os estudantes, mesmo aqueles que não vão seguir carreira acadêmica científica, devem sentir-se confortáveis ao enfrentarem assuntos científicos, sendo assim, devem conhecer as tradições, convenções e práticas científicas (YORE e HAND, 2010). Os conhecimentos científicos participam da tomada de decisões, mas a ética da ciência e o valor desses conhecimentos também são importantes para relativizar o peso que a informação científica tem na vida dos cidadãos. 
a. Alfabetização científica e argumentação

Quando o cientista inscreve a realidade na forma de resultados de um projeto, quando estes resultados vão ser confrontados com as teorias vigentes, quando o cientista publica seus resultados e discussões no formato de artigo científico, quando ele defende esses resultados perante a comunidade científica, ele se utiliza da linguagem. Mais especificamente, grande parte dessa linguagem é persuasiva, argumentativa, de forma a estabelecer os conhecimentos elaborados em um longo caminho de investigação (DRIVER; NEWTON; OSBORNE, 2000).

A linguagem argumentativa está presente no cotidiano do cientista desde as reuniões de laboratório, em que os pesquisadores de um mesmo grupo verificam resultados de pesquisa e constroem conclusões, até encontros regionais ou internacionais (p.ex. simpósios, congressos), nos quais os profissionais de diferentes laboratórios e linhas de pesquisa discutem e colocam suas conclusões à prova (OSBORNE; ERDURAN; SIMON, 2004; SAMPSON e CLARK, 2008; MCNEILL, 2009). Essa linguagem também está presente nos artigos publicados que pressupõem uma avaliação anônima por pares, aumentando o rigor do processo de validação de conclusões científicas.

Podemos ainda analisar a produção científica de maneira histórica. 0 estabelecimento de teorias e conceitos científicos ocorre em uma escala temporal que envolve dezenas ou centenas de anos. Também nesses casos, o acúmulo de pesquisas, congressos e artigos a favor de uma teoria faz com que ela se estabeleça na comunidade científica. Esse processo mais longo também é persuasivo e depende da argumentação conjunta que o acúmulo de trabalhos proporciona. A escrita nessa forma específica da ciência é dominante no trabalho do cientista e ocupa aproximadamente dois terços do tempo do cientista em suas atividades (LATOUR e WOOLGAR, 1997).

Retomando a ideia de alfabetização científica, em que mais elementos da ciência devem ser apresentados aos alunos, uma atividade de ocupa dois terços do tempo do cientista não poderia ser ignorada em seu ensino. Se o cientista constrói seus conhecimentos na forma de argumentos persuasivos, o ensino de ciência deveria contemplar essa prática. Ao ensinar o conceito pronto e com status de verdade, o papel das evidências e justificativas teóricas usadas para defender esses conceitos é ignorado. $\mathrm{O}$ aluno 
recebe informações prontas e incontestáveis, quando, na verdade, essas informações são resultado da soma de fatores que levaram alguém a concluir tal conceito.

A ideia de "Ensino de Ciências como argumentação" vem sendo levantada por diversos autores (DRIVER; NEWTON; OSBORNE, 2000; SIMON; ERDURAN; OSBORNE, 2006; SAMPSON e CLARK, 2008; KUHN, 2010). Um dos primeiros trabalhos na área que analisou a argumentação em aulas de ciências defendeu que o professor deve contar ao aluno o porquê dos conceitos serem aceitos e da mesma forma que o cientista faz com seus pares, convencer seu aluno sobre esse conceito (RUSSEL, 1983). Com o foco na argumentação, fica mais fácil demonstrar a construção do conhecimento científico e aproximar os estudantes dessa prática (BRICKER e BELL, 2008).

Segundo as ideias acima, a prática argumentativa é um objetivo das aulas de ciências (SIMON; ERDURAN; OSBORNE, 2006). Argumentação é o processo de construção de um argumento. Argumento, como produto, é uma asserção acompanhada de justificativa ou ainda, conclusão suportada por pelo menos uma razão (DAWSON e VENVILLE, 2009). processo de construir um argumento inclui uma afirmação e as razões que estabelecem essa afirmação.

Alguns autores defendem que quem argumenta considera hipóteses contrárias (SIMON; ERDURAN; OSBORNE, 2006). Isso é válido para um processo argumentativo em que uma opinião contrária é colocada em relação à outra, por exemplo, a criação ou não de um zoológico. Nesse exemplo já se dá as duas possibilidades. Em contrapartida, há questões em que a opinião do aluno é considerada a defesa de um ponto de vista (DAWSON e VENVILLE, 2009). Nesses casos, não é necessário levar em consideração a opinião contrária, basta dar a sua opinião. A primeira situação explicita uma comparação e pede que o sujeito se posicione em relação a essa comparação, enquanto o segundo tipo de situação apenas pergunta o que o sujeito acha certo. Neste trabalho, entendemos a argumentação como proposto por Toulmin (2006), argumentamos ao tentar justificar afirmações, ou ainda argumentamos ao construir afirmações justificadas a partir de conhecimento usando ideias teóricas e evidências empíricas (McNEILL, 2009).

De qualquer forma, para que o argumento seja persuasivo e convincente cientificamente, deve ser consistente com os critérios epistemológicos da comunidade científica (SAMPSON e CLARK, 2008), ou seja, deve estar embasado em evidências e teorias aceitas pela ciência. A argumentação poderia ser utilizada em outros campos do 
conhecimento, como política ou direito (KUHN, 2010), mas para que seja aceito como científico, deve conter os conceitos típicos das práticas específicas da ciência. Portanto, o leque de informações que podem ser veiculadas nesse meio é restrito.

O "Ensino de Ciências como argumentação" pode ser um meio de atingir metas epistêmicas, cognitivas e sociais da ciência, bem como aumentar e facilitar o aprendizado de conceitos científicos. Visto desta forma, ensinar argumentação não se encerra na prática argumentativa. A prática argumentativa ajuda o aluno a pensar cientificamente, a entender como os conhecimentos da ciência são construídos e estabelecidos pela comunidade científica, facilita o aprendizado dos conteúdos conceituais escolarizados a partir do conhecimento científico (OSBORNE; ERDURAN; SIMON, 2004; VONAUFSCHNAITER et al., 2008).

Concordamos, portanto, com a importância da alfabetização científica e defendemos a abrangência que as práticas discursivas da ciência têm em sala de aula para atingir as metas colocadas pela alfabetização científica (KUHN, 2010). Não pretendemos negligenciar os outros objetivos do ensino de ciências (ZEMBAL-SAUL, 2009; KUHN, 2007), mas queremos tratar especificamente da argumentação científica no espaço escolar.

É preciso ressaltar também que a prática argumentativa científica não é intuitiva nem direta, pois para que o aluno seja capaz de construir argumentos ele deve apresentar conhecimentos nas áreas científicas e também deve apresentar habilidades linguísticas (TOULMIN, 2006; JIMÉNEZ e DÍAZ, 2003). Trata-se de um desenvolvimento abrangente em que todas as facetas devem ser valorizadas, tanto o domínio dos conhecimentos construídos pela ciência (VONAUFSCHNAITER et al., 2008), como a articulação desses conhecimentos de forma persuasiva.

A partir das ideias abordadas pretendemos analisar como a argumentação é usada em uma aula de ciências. Estamos interessados nos processos que estimulam a argumentação dos alunos e na argumentação dos alunos como indicativo de que outras características das ciências, além de seus conhecimentos, estão sendo tratadas. 
b. Pesquisas sobre argumentação

As pesquisas sobre a argumentação em sala de aula aumentaram na última década pelas áreas de ensino de ciências e estão entre os trabalhos mais citados (ex. NEWTON; DRIVER; OSBORNE, 1999; DRIVER; NEWTON; OSBORNE, 2000). Além disso, há uma recente internacionalização das pesquisas, verificada por meio do aumento dos trabalhos de outros países em revistas de língua inglesa (LEE; WU; TSAI, 2009). O conhecimento construído pela área sustenta a importância da argumentação como componente da ciência e por isso, muitas pesquisas atuais incentivam o seu uso em sala de aula (CHAMIZO, 2007).

A variedade de estudos realizada reflete também uma variedade de perspectivas de análise (McNEILL, 2009). Os trabalhos de pesquisa sobre argumentação abrangem desde como os alunos argumentam em diferentes situações até quais conceitos são ou não veiculados pelos alunos durante suas discussões (JIMÉNEZ; PÉREZ; CASTRO, 1998; JIMÉNEZ e DÍAZ, 2003; ERDURAN; SIMON; OSBORNE, 2004; SIMON; ERDURAN; OSBORNE, 2006; CARVALHO, 2008; ZEMBAL-SAUL, 2009).

A análise do discurso argumentativo é considerada uma das maneiras de se acessar as questões relacionadas com o conhecimento (raciocínio e aporte teórico). Também identificamos pesquisas que defendem a argumentação como forma de aprender a importância da linguagem na ciência, como possível método a ser usado para aumentar compreensão de conceitos e promover o raciocínio científico.

Jiménez e Díaz (2003) discutem diferentes metodologias usadas na literatura para analisar o aporte teórico dos alunos, dentre elas, a argumentação. Bricker e Bell (2008) discutem o papel da argumentação no ensino de ciências, problematizam as metodologias de pesquisa e indicam a importância da argumentação como prática central da ciência. Os autores defendem que a argumentação em sala de aula deve ser usada com múltiplos fins: o aprendizado de conceitos, o discurso científico e o funcionamento da ciência.

Nascimento e Vieira (2008) apresentam as contribuições e limites de um modelo específico de análise da argumentação, o modelo de Toulmin (2006). Os autores indicam a necessidade de aperfeiçoamento da ferramenta, mas indicam como vantagem do modelo a possibilidade de identificar os elementos lógicos do argumento. Zembal-saul (2009) se utiliza do modelo de argumentação de Toulmin (2006) para analisar trabalhos da educação infantil. 
A autora indica o uso da argumentação em sala de aula como a atenção ao discurso de sala de aula e o papel do professor em monitorar e auxiliar o raciocínio dos alunos.

Von Aufschnaiter e colaboradores (2008) investigaram as práticas argumentativas em situações científicas e sócio científicas e relataram a importância da argumentação no desenvolvimento do conhecimento científico. Os autores afirmam que quando os alunos se engajam nesse tipo de atividade eles se apoiam em seus conhecimentos anteriores, consolidam e elaboram o seu conhecimento sobre a ciência e conseguem atingir níveis de abstração relativamente altos.

Grace (2009) discute a importância da argumentação no desenvolvimento do raciocínio sobre conservação biológica e se há características típicas dos argumentos às quais o professor deve estar atento. $\mathrm{O}$ autor afirma que a argumentação ajuda os alunos a melhorarem seu raciocínio e indica elementos da argumentação como indicadores de boa qualidade na tomada de decisão. Além das vantagens pedagógicas explicitadas por essas pesquisas e outras pesquisas (LEMKE, 1990; MORTIMER e SCOTT, 2002), em diversos países as diretrizes curriculares começaram a indicar a argumentação como importante personagem nas aulas de ciências (SIMON; ERDURAN; OSBORNE, 2006; NASCIMENTO e VIEIRA, 2008; ZEMBAL-SAUL, 2009).

Apesar da importância dada à argumentação, não é clara a forma como estudantes se tornam fluentes nessa linguagem (CHANG e CHIU, 2008). O estudo mostra que pessoas formadas em disciplinas não científicas têm o mesmo desempenho que estudantes do ensino básico em questões científicas a partir da análise de outra ferramenta argumentativa. O estudo indica ainda que existem ideias difíceis de serem superadas pelos alunos e ressalta a necessidade de ampliar as pesquisas nessa área.

Dawson e Venville (2009) publicaram um dentre muitos trabalhos que revelam que a habilidade argumentativa dos alunos é baixa. Porém, a partir da análise de diferentes pesquisas sobre argumentação, mostrou-se difícil comparar métodos de análise e, por isso, afirmar seguramente a capacidade argumentativa dos alunos. Cada pesquisa usa parâmetros de análise diferentes, o caráter das análises é, de certa forma, subjetivo e comparações diretas ficam impossibilitadas (CLARK e SAMPSON, 2008; SAMPSON e CLARK, 2008).

Alguns pesquisadores usam a argumentação no ensino de ciências a partir da proposição de problemas autênticos ou questões controversas aos alunos (JIMÉNEZ e DÍAZ, 2003; ERDURAN; SIMON; OSBORNE, 2004). Há também na área de pesquisa trabalhos que 
investigam a argumentação sobre conceitos científicos (VONAUFSCHNAITER et al., 2008; RUSSEL, 1983; JIMÉNEZ; PÉREZ; CASTRO, 1998; ZEMBAL-SAUL, 2009). Sampson e Clark (2008) indicam três principais tipos de pesquisas feitas sobre argumentação. O primeiro tipo se interessa pela estrutura e complexidade dos argumentos, o segundo tipo se interessa pelo conteúdo dos argumentos quando avaliados por uma perspectiva científica. Por fim, o terceiro tipo se interessa pela natureza das justificativas apresentadas.

Considerando as classificações feitas acima, o trabalho apresentado aqui se aproxima daqueles que tratam de problemas científicos e que analisam a estrutura, complexidade e conteúdo dos argumentos. Estamos interessados em estabelecer se os alunos são capazes de construir argumentos científicos para justificar uma afirmação, se são capazes de reunir o conhecimento veiculado nas aulas em forma de justificativa para embasar seus argumentos.

c. O professor e os objetivos do ensino de ciências

A figura do professor em sala de aula é uma das marcas da escola. Mais do que uma autoridade por ser professor, esta figura que fica à frente da sala de aula é a fonte do conhecimento na área em que atua. No caso das ciências ocorre o mesmo e o professor é o representante do conhecimento científico (RUSSEL, 1983). Considerando a maneira como a ciência se estabelece, o professor de ciências deve conseguir justificar os conceitos científicos com base nas evidências e teorias que o embasam (RUSSEL, 1983).

Sem perder o foco dos nossos objetivos, nos aproximamos da visão construtivista de ensino de ciências que prevê que a função do professor é a mesma de um pesquisador orientador que guia seus alunos em seus estudos e os ajuda a entender, complementar ou até mesmo questionar resultados de experimentos (GIL-PÉREZ et al., 2002). O professor não dá todas as respostas ao aluno, mas também não o deixa desamparado na resolução dos problemas.

Por outro lado, num esforço de não condenar categoricamente nenhuma estratégia didática, consideramos as vantagens da instrução direta. Dependendo dos objetivos de cada instrução, uma mesma estratégia didática pode ter sucessos diferentes (KUHN, 2007). Os objetivos do ensino de ciências compreendem mais do que só os conteúdos ou só o utilitário 
da ciência, ou seja, devemos examinar os objetivos e conteúdos de cada prática antes de aplicarmos nossos juízos de valor.

Kischner, Sweller e Clark (2006) escreveram um artigo em certa medida polêmico sobre o assunto, em que colocaram à prova a maneira correta de se ensinar. Os autores tentam demonstrar que alguns tipos de ensino por resolução de problemas deixam o aluno perdido e sem instrução o suficiente para avançar em seu aprendizado e defendem que a instrução direta (quando o professor fala e os alunos ouvem) é a melhor didática de ensino. $\mathrm{O}$ argumento apresentado por esses autores foi rebatido em um volume especial do periódico em que fora publicado, principalmente porque se entende que não há uma maneira única de ensinar, nem tampouco um único objetivo para as práticas de sala de aula (KUHN, 2007). A escola tem funções éticas e sociais e o ensino que tente atingir esses objetivos não pode assumir que o acúmulo de conhecimentos conceituais dará conta de práticas e procedimentos da ciência.

Se tivermos como objetivo a alfabetização científica dos alunos, devemos planejar as sequências de aula de forma a contemplar elementos da ciência e aproximar os alunos desses elementos. O discurso argumentativo, um dos elementos de interesse da alfabetização científica, requer treino, não é uma tarefa fácil. O professor deve, não só conseguir argumentar, mas também conseguir provocar nos alunos comportamento semelhante (CARLSEN, 2007).

Os alunos não podem simplesmente ser informados de como é a ciência e que papel a argumentação tem em sua construção (KUHN, 2010). Tem sido relatada uma distância entre o que se pesquisa e como se atua no ensino básico. As práticas argumentativas são omitidas em sala de aula e alguns autores indicam que os cursos de formação inicial dos professores são distanciados das pesquisas sobre Ensino de Ciências (NASCIMENTO e VIEIRA, 2008).

Existem características específicas na atividade de um professor para provocar e proporcionar a argumentação científica dos alunos. A própria postura do professor frente ao conhecimento científico é uma forma de passar imagens sobre a natureza da ciência. Professores de ciências deveriam usar evidências e argumentos racionais para ensinar os conceitos da disciplina (RUSSEL, 1983).

Perguntas interessantes a serem usadas em atividades que envolvam argumentação seriam: por que você acha isso? Você consegue pensar em outro argumento para o seu 
ponto de vista? Você consegue pensar em um argumento contrário ao seu? (SIMON; ERDURAN; OSBORNE, 2006). Professores com postura reflexiva geralmente estão envolvidos com inovações educativas e se destacam da maioria (JIMÉNEZ e DÍAZ, 2003), o que nos leva a crer que os estímulos à argumentação também são parte do treino e reflexão da profissão de professor.

É importante que os professores construam estratégias de ensino que tenham como objetivo a argumentação (JIMÉNEZ e DÍAZ, 2003). As perguntas feitas pelo professor em sala de aula podem ser decisivas. Perguntas de memorização são menos interessantes que perguntas como as citadas acima, pois dão muito foco aos nomes de conceitos sem exigir a compreensão do aluno (KRASILCHIK, 2008). Além disso, é importante que o professor consiga mostrar ao aluno, a partir de argumentos, como os conceitos científicos são articulados e quais as justificativas para o conhecimento científico estabelecido hoje (RUSSEL, 1983).

Tendo em vista o que foi abordado nesse resgate bibliográfico, pretendemos analisar a argumentação em uma sequência de aulas de biologia. Gostaríamos de entender como a professora estimula os alunos a argumentarem, se a professora fornece argumentos, seja em sua fala, seja no material didático usado, se os alunos produzem argumentos em um exercício escrito e se é possível relacionar a argumentação fornecida nas aulas com os exercícios escritos dos alunos. 


\section{2- Objetivos}

A partir da união das ideias deste trabalho, pretendemos analisar a argumentação científica em uma aula de ciências, nos momentos em que é fornecida aos alunos pelos materiais expostos e nos momentos em que os alunos se apropriam desse gênero de linguagem. Como fora dito anteriormente, a argumentação é um elemento dominante da cultura científica, sendo assim, sua prática em aulas de ciências se torna imperativa. Propomos como objetivos específicos:

a. Identificar ações pró-argumentação pela professora durante as aulas;

b. Identificar os argumentos fornecidos pela professora e pelo texto lido em sala durante as aulas;

c. Identificar e classificar os argumentos produzidos pelos alunos nas respostas escritas ao exercício proposto pela professora;

d. Relacionar os argumentos fornecidos em aula (professora e texto) com os argumentos produzidos pelos alunos. 


\section{3- Métodos}

\section{Referenciais metodológicos}

a. Ações pró-argumentação

Para a análise da argumentação como ferramenta de ensino, as falas da professora foram correlacionadas com a tabela criada por Simon, Erduran e Osborne (2006). O trabalho dos autores foi escrito com base nas novas propostas de currículo na Inglaterra, que colocava o inquiry como novo foco das aulas de ciências no país. O trabalho desenvolvido ao longo de um ano com doze professores voluntários resultou em uma hierarquização de estratégias pedagógicas para a prática argumentativa.

O trabalho se insere na mesma linha de ensino de ciências como argumentação e defende que o ensino da argumentação promove a melhoria de vários aspectos do conhecimento. $\mathrm{O}$ argumento e seu processo de montagem dependem de instrução explícita e os professores precisam dominar as práticas argumentativas e trabalhá-las em sala de aula de forma gradativa (SIMON; ERDURAN; OSBORNE, 2006).

O objetivo do trabalho era identificar quantas vezes os professores se engajavam na prática argumentativa, quão complexos foram os argumentos construídos e quantas vezes se posicionaram frente ao argumento dos alunos. A análise dos professores foi feita a partir de uma tabela previamente criada com base em outro trabalho dos mesmos autores. Por meio dela é possível entender a hierarquização das estratégias pedagógicas próargumentação (Tabela 01). Estamos interessados em classificar as falas da professora durante as aulas segundo os códigos propostos por esses autores.

A coluna um expressa os códigos que representam tipos de objetivos para o ensino de argumentação. Os códigos podem ser inseridos em categorias mais amplas sobre os objetivos do Ensino de ciências. A categoria falar e escutar apresenta dois códigos: "encorajar a discussão", quando o professor indica que haverá discussão sobre o assunto e "encorajar a ouvir", quando o professor ressalta explicitamente a importância de ouvir a opinião do outro para poder discutir sobre as suas ideias. 
Algumas categorias (coluna dois) parecem óbvias quando o intuito é estimular a argumentação, como saber o que significa um argumento, construir e avaliar argumento, mas as outras categorias também são importantes, como refletir sobre o processo argumentativo ou justificar com evidências. As categorias estão dispostas em ordem hierárquica, ou seja, a prática argumentativa deve ser inserida gradativamente pela ordem hierárquica (SIMON; ERDURAN; OSBORNE, 2006).

Tabela 01: Códigos e categorias de ação do professor consideradas pró-argumentação. Baseada na tradução de Simon; Erduran e Osborne (2006).

\begin{tabular}{|c|c|}
\hline $\begin{array}{l}\text { Códigos para as falas do professor que têm como } \\
\text { objetivo a argumentação }\end{array}$ & $\begin{array}{l}\text { Categorias de processos argumentativos refletidos nas } \\
\text { falas do professor }\end{array}$ \\
\hline Encorajar a discussão & Falar e escutar \\
\hline \multicolumn{2}{|l|}{ Encorajar ouvir } \\
\hline Definir argumento & Saber o que significa argumento \\
\hline \multicolumn{2}{|l|}{ Exemplificar argumento } \\
\hline Encorajar ideias & Posicionar-se \\
\hline \multicolumn{2}{|l|}{ Encorajar o posicionamento } \\
\hline \multicolumn{2}{|l|}{ Valorizar posições diferentes } \\
\hline Conferir evidências & Justificar com evidências \\
\hline \multicolumn{2}{|l|}{ Fornecer evidências } \\
\hline \multicolumn{2}{|l|}{ Incitar o uso de justificativa } \\
\hline \multicolumn{2}{|l|}{ Enfatizar a justificativa } \\
\hline \multicolumn{2}{|l|}{ Encorajar melhores justificativas } \\
\hline \multicolumn{2}{|l|}{ Fazer-se de advogado do Diabo } \\
\hline Usar ou preparar exemplos escritos & Construir argumento \\
\hline \multicolumn{2}{|l|}{ Oferecer/dar papéis a serem seguidos } \\
\hline Encorajar a avaliação & Avaliar de argumentos \\
\hline \multicolumn{2}{|l|}{ Avaliar argumentos } \\
\hline \multicolumn{2}{|l|}{ Processo - usar de evidências } \\
\hline \multicolumn{2}{|l|}{ Conteúdo - natureza da evidência } \\
\hline Encorajar a antecipar contra-argumentos & Contra argumentar/debater \\
\hline \multicolumn{2}{|l|}{ Encorajar o debate (através de papéis) } \\
\hline Encorajar a reflexão & Refletir sobre o processo argumentativo \\
\hline Perguntar sobre mudanças de opinião & \\
\hline
\end{tabular}

Os códigos criados serão usados de acordo com a natureza da atividade proposta. Questões que apresentam controvérsia possibilitam o estímulo de habilidades mais complexas como contra argumentar ou antecipar contra-argumentos, mas questões de resposta única não chegarão a essas etapas. O professor estimula a argumentação dos alunos e são as suas ações que são enquadradas segundo a tabela proposta. 
b. Argumentação

Os trabalhos recentes sobre argumentação em salas de aula se utilizam de uma ferramenta de análise trazida da filosofia (TOULMIN, 2006). O modelo de argumento, posteriormente nomeado modelo de Toulmin, foi sugerido na obra Os usos do argumento (TOULMIN, 2006) tem como função quebrar as amarras da lógica formal que distanciam o pensamento cotidiano do status de argumentação (HENAO e STIPCICH, 2008). Apesar da obra ter sido originalmente escrita no contexto da argumentação legal (BRICKER e BELL, 2008), para Toulmin, argumentamos ao tentar justificar afirmações, seja sobre a possibilidade de um jogador estar ou não estar na seleção, seja sobre quais evidências levaram o cientista a concluir como algum hormônio age no organismo.

Como resultado do ataque à lógica formal, quando lançada, a obra foi criticada pelos filósofos. Entretanto, ao mesmo tempo em que foi criticada dentro da filosofia, outras áreas do conhecimento, como comunicação e direito, consideraram a obra interessante e aplicável. Em 1981, o modelo de argumento proposto na obra foi usado para caracterizar a autoridade conceitual na fala de professores de ciências (RUSSEL, 1983). Desde então vem crescendo o número de trabalhos que utilizam essa ferramenta analítica.

Jiménez e Díaz (2003) concordam com a utilização da argumentação tal como Toulmin propôs (2006), e afirmam que, apesar das falas dos alunos não serem corretas conceitualmente ou serem falaciosas segundo a lógica formal, nos servem para identificar os processos de construção do conhecimento. A argumentação em um contexto educativo não segue os mesmos padrões que a argumentação em filosofia, pois os alunos ainda não estão treinados o suficiente para apresentarem o nível de precisão e abstração exigidas na filosofia (JIMÉNEZ e DÍAZ, 2003; HENAO e STIPCICH, 2008).

Trabalhos na área revelam usos relativamente aprofundados da ferramenta, partindo do uso do padrão argumentativo de Toulmin para ressaltar a necessidade de justificar afirmações com base em evidências e teorias científicas (ZEMBAL-SAUL, 2009), chegando a analisar elementos particulares (p.ex. refutação) do modelo de argumentação para estabelecer o grau de elaboração dos argumentos dos alunos (ERDURAN; SIMON; OSBORNE, 2004). Atualmente, esse modelo de argumentação tem sido endossado inclusive por documentos curriculares europeus (MARTIN e HAND, 2009). 
Muitos trabalhos se fixam na possibilidade de construção de argumentos em grupo, momentos em que professor e aluno ou um grupo de alunos discute e organiza conclusões e justificativas em mais de uma pessoa (ZEMBAL-SAUL, 2009; ERDURAN; SIMON; OSBORNE, 2004; JIMÉNEZ e DÍAZ, 2003; SIMON; ERDURAN; OSBORNE, 2006; VONAUFSCHNAITER et al., 2008). Nesses casos uma pessoa faz uma afirmação e as outras enumeram as justificativas. Também se faz possível a análise de argumentos dos alunos em trabalhos escritos. Estes consideram o argumento construído por um aluno individualmente. Em ambas as situações, entendemos que o argumento construído carrega a influência do professor e dos outros alunos durante as discussões (OROFINO et al., 2009).

O padrão argumentativo de Toulmin (2006) é formado por elementos distinguíveis (Figura 01). Ao fazer uma afirmação (Conclusão - C), posso ser convidado a justificá-la. Para isso, utilizo um fato (Dado - D) que me permite tal conclusão devido a uma justificativa (Garantia - W). Tal justificativa é embasada em conceitos, leis gerais (Apoio - B). Posso ainda dizer em quais condições minha afirmação é falsa (Refutação - R) e ainda delimitar qual é a força da conclusão a partir da justificativa apresentada (Qualificador - Q).

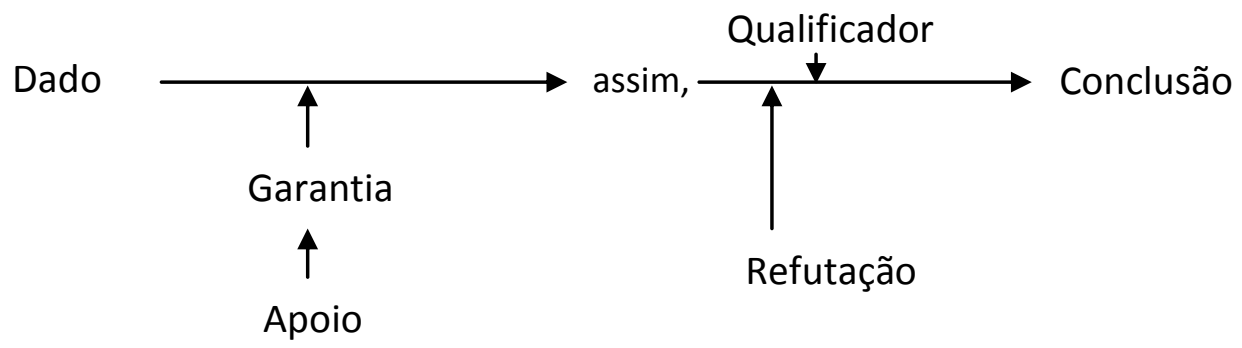

Figura 01. Esquema de argumento segundo o padrão de Toulmin (2006).

Quando construímos um argumento segundo esse padrão conseguimos evidenciar os elementos descritos. De forma ilustrativa: afirmo que não sairei de casa hoje (Conclusão). Ao me perguntarem por que, respondo: pois chove lá fora (Dado). Se meu interlocutor não se sentir satisfeito com minha resposta, Ihe digo: Já que sei que se sair, certamente me molharei (Garantia), uma vez que a chuva é feita de água e a água molha (Apoio). Consigo dizer convicta que certamente (Qualificador) não sairei de casa devido à certeza de que a água molha, a menos que ache um guarda-chuva, uma capa e um par de galochas (Refutação). 
Da forma como descrita, fica implícito que argumentar é um processo de justificar asserções a partir de dados, garantias e apoios para convencer um determinado público. Sendo assim, quanto mais elementos combinados um argumento apresentar, mais forte ele será (SAMPSON e CLARK, 2008). Ao lermos a explicação dada pelo autor (TOULMIN, 2006), podemos identificar melhor cada elemento do padrão.

Os dados são os fatos que relacionamos a uma afirmação (Pp. 140), "Em cada caso, uma asserção original apoia-se em fatos apresentados que se relacionam a ela". As garantias são informações adicionais que permitem a ligação do fato à afirmação feita (Pp. 141): "Temos sim de apresentar proposições de um tipo bem diferente: regras, princípios, licenças de inferência [...] desde que não sejam novos itens de informação"; ou ainda (Pp. 140) "Pode acontecer de alguém nos pedir não que acrescentemos novas informações factuais, além das que apresentamos, mas que indiquemos a relação que os dados já apresentados têm com nossa conclusão.".

O apoio são as regras gerais que permitem a construção da garantia (Pp. 148): “[...] por trás de nossas garantias normalmente haverá outros avais, sem os quais nem as próprias garantias teriam autoridade ou vigência". Os qualificadores são responsáveis pela força desse argumento construído (Pp. 145): “[...] pode ser preciso acrescentar alguma referência explícita ao grau de força que nossos dados conferem à nossa alegação em virtude de nossa garantia". Por fim, a refutação é responsável pelo descrédito da garantia apresentada (Pp. 145): "[...] indicam circunstâncias nas quais se tem de deixar de lado a autoridade geral da garantia".

Ou seja, há algo expresso nos dados ou na garantia que delimita a amplitude do argumento. Quando a garantia dá tom de certeza à afirmação construída devido a uma lei geral positiva, o qualificador será "certamente". Haverá casos em que essa certeza não poderá ser expressa, logo, o locutor deve expressar o termo que caiba à garantia dada, como possivelmente, provavelmente, certamente não, etc.

Em outro momento, a distinção entre o apoio, o qualificador e a refutação, respectivamente, também nos ajuda a compreender melhor o papel desses elementos:

[...] uma coisa são os motivos para considerar aceitável uma garantia, outra coisa é a força que a garantia empresta a uma conclusão e uma terceira coisa são os tipos de circunstâncias excepcionais que, em casos específicos, podem refutar as suposições criadas pela garantia. (Pp. 153). 
O uso do padrão de argumentação de Toulmin permite uma análise quantitativa e qualitativa dos argumentos (DRIVER; NEWTON; OSBORNE, 2000; SIMON; ERDURAN; OSBORNE, 2006). Porém, ao considerar a referência de análise dos argumentos percebemos que a identificação dos mesmos é dificultada na análise (ERDURAN; SIMON; OSBORNE, 2004), pois muitas vezes se faz confusão sobre o que seriam dados, garantias ou apoios na fala dos alunos. Em sua obra, Toulmin reconhece tal dificuldade, mas indica uma forma de tentarmos resolvê-la:

Será que sempre percebemos claramente se um homem que desafia uma asserção pede que o adversário the apresente ou os dados ou as garantias que autorizam os passos? Em outras palavras: há meios para distinguirmos claramente entre a força de (a) 'o que você tinha pra seguir em frente?' e (b) 'como você chegou aí?' [...] De qualquer modo, temos de entender que é possível, em algumas situações, distinguir claramente entre duas funções

lógicas diferentes; e pode-se começar a perceber a natureza desta distinção, se se comparam duas sentenças como (a) 'sempre que $A$, alguém constatou B' e (b) 'sempre que A, pode-se assumir que B'. (pp. 142)

Sobre a dificuldade de diferenciar garantias de apoios, o autor comenta que (Pp. 151) "[...] estas confusões só surgem quando as diferenças são mascaradas pelas nossas formas de expressão".

O autor dá o seguinte exemplo:

Petersen é sueco;

A proporção de suecos católicos romanos é zero;

Logo, com certeza, Petersen não é católico romano.

Petersen é sueco;

Um sueco não é, com certeza, católico romano;

Logo, com certeza, Petersen não é católico romano. (Pp. 158)

Enquanto o primeiro argumento é expresso na forma " $D, B$, logo $C$ ", o segundo é expresso na forma " $D, W$, logo C", pois se trata de uma generalização a partir do apoio, que, por sua vez, é o próprio conceito:

Afirmar o apoio para nossa garantia, neste caso, envolve, inevitavelmente, a menção a Atos do Parlamento e coisas semelhantes, e essas referências destroem a elegância formal do argumento. Também em outros campos, mencionar explicitamente o apoio para a nossa garantia - quer assuma a forma de relatórios estatísticos, apelos aos resultados de experiências ou referências a sistemas taxonômicos - nos impedirá de escrever o argumento de forma tal que ele seja evidentemente válido só pelas propriedades formais. (Pp.176). 
O modo "D, W logo C" expressa, quando comparado ao modelo de argumento silogístico, a premissa menor, a premissa maior, logo a conclusão. Como consequência, atende às necessidades para ser considerado válido em forma. Quando se apresenta $D, B$ logo $C$, isso se perde, e mesmo que conceitualmente o argumento seja correto, perde a elegância e a validade formais. O modelo apresentado (Figura 02), portanto, não deixa espaços para ambiguidades entre garantia e apoio:

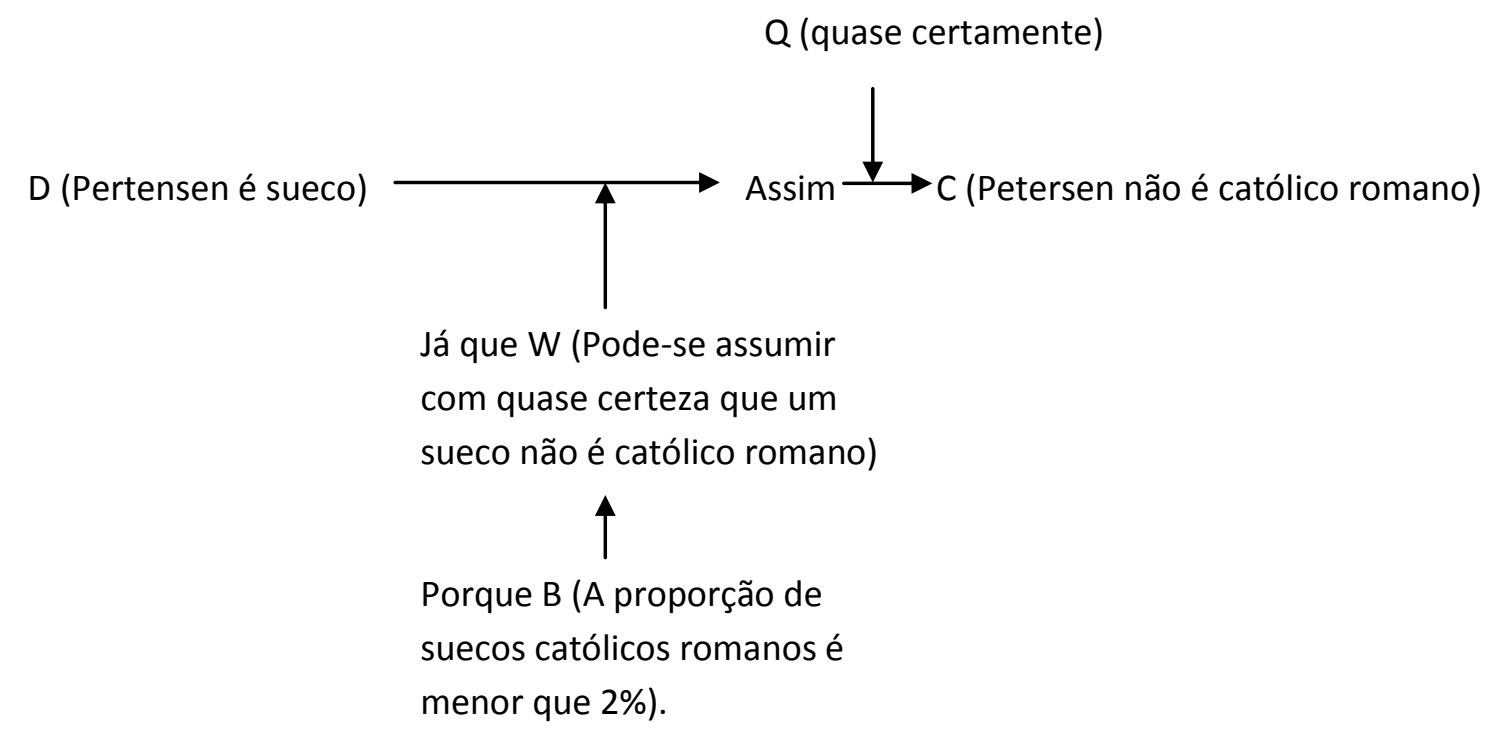

Figura 02: Exemplo de como o uso completo do argumento de Toulmin (2006, Pp. 159) evita confusões formais.

Quando o autor critica o silogismo por que (Pp. 170) “[...] a conclusão resulta simplesmente de se embaralhar as partes das premissas e de rearrumá-las num outro molde", faz uma crítica ao modelo de argumentação tradicional. Porém, na área de educação essa discussão não cabe. A ideia proposta acima é válida no momento de construção de um argumento, quando o locutor tem consciência de que está construindo um argumento embasado em conceitos ou leis gerais e generalizações a partir desses conceitos e leis.

O formato linguístico do argumento proposto por Toulmin (2006) não é nem único nem consensual. Esse modelo foi usado inicialmente por possibilitar uma análise crítica das afirmações científicas (RUSSEL, 1983). A argumentação é importante não só para os contextos científicos, mas para todos os contextos da vida do aluno (OSBORNE; ERDURAN; SIMON, 2004) e é desenvolvida na escola em diferentes momentos e disciplinas, não cabendo às aulas de ciências a sistematização linguística de argumentos. 
Seria suficiente se conseguíssemos identificar se os alunos conseguem justificar suas afirmações e não restringirmos à figura da garantia, pois alguns alunos utilizam o apoio ao invés da garantia ou se limitam a explicitar o dado que permite determinada conclusão. Tal movimento é compreensível se relembrarmos que os alunos não aprendem esse modelo de argumentação. No nível linguístico que utilizamos a ferramenta estabelecida por Toulmin (2006), independe se consideraremos a fala do aluno como garantia ou apoio. Estamos preocupados em entender se o aluno é capaz de justificar suas afirmações a partir de conhecimentos científicos, independente se ele o fará pela generalização de um conceito ou pelo próprio conceito.

Apesar da explicação acima sobre o significado de cada elemento do argumento deixar aparentemente clara a diferença entre a garantia e o apoio, muitos pesquisadores relatam a dificuldade de diferenciá-las no momento da análise de uma fala ou de um texto escrito (cf. JIMÉNEZ e DÍAZ, 2003; SIMON; ERDURAN; OSBORNE, 2006, HENAO e STIPCICH, 2008). Propusemos, para esse estudo em particular, uma simplificação do modelo de argumento utilizado para a análise, unindo garantia e apoio em um só elemento, chamado de justificativa (Figura 03). Dessa forma, assim como diversos autores fizeram (DRIVER; SIMON; OSBORNE, 2000; JIMÉNEZ; PÉREZ; CASTRO, 1998; DRIVER; NEWTON; OSBORNE, 2000; VILLANI e NASCIMENTO, 2003), adaptamos o modelo às nossas necessidades refletindo o desenho experimental e os objetivos dessa pesquisa (SAMPSON e CLARK, 2008).

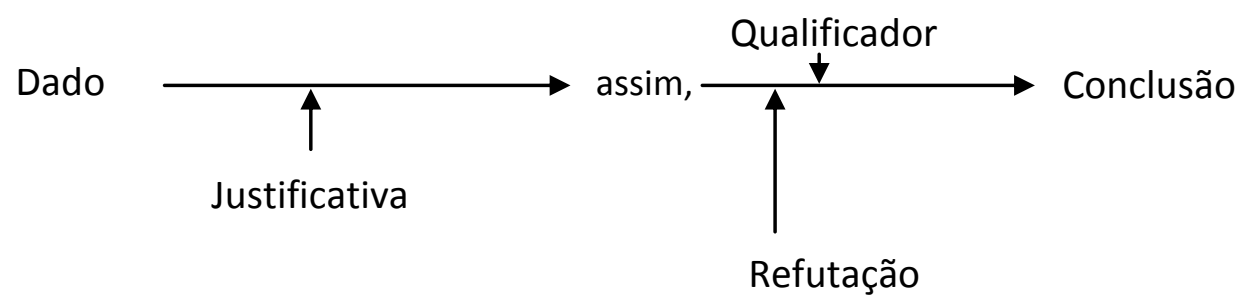

Figura 03: proposta de modelo de análise de argumento para a situação estudada. Modelo derivado o modelo proposto por Toulmin (2006), com simplificações que ignoram a natureza da justificativa.

A literatura sobre argumentação aponta como principal crítica ao modelo de Toulmin a desconsideração do contexto de produção dos argumentos e a falta de precisão para julgáIos (NASCIMENTO e VIEIRA, 2008). A obra compreende uma discussão sobre a "campodependência" dos elementos do argumento, mas segundo Sampson e Clark (2008), o modelo em si nos dá poucas informações sobre essa característica dos elementos. Sendo 
assim, nos restam dúvidas de como as informações conceituais se relacionam (SAMPSON e CLARK, 2008).

Segundo alguns autores, o modelo nos permite encaixar informações independente de sua relevância ou coerência (SAMPSON e CLARK, 2008; HENAO e STIPCICH, 2008; ERDURAN; SIMON; OSBORNE, 2004; SIMON; ERDURAN; OSBORNE, 2006). Porém, autores que se debruçaram sobre a epistemologia e filosofia das ciências afirmam que isso se deve a um esvaziamento do conteúdo da obra de Toulmin (2006) que nos leva a usar incorretamente o modelo como um quebra-cabeça (BRICKER e BELL, 2008).

Concordamos com a importância da argumentação na ciência e queremos entender como o aluno consegue veicular os conhecimentos de aula, sem nos preocuparmos se o aluno é capaz de seguir regras formais de argumentação, sejam essas regras quais forem. Além disso, concordamos com Bricker e Bell (2008) sobre a contextualização das análises. Sendo assim, propomos abaixo o uso da ferramenta de acordo com nossos objetivos de pesquisa.

\section{Fatores condicionantes da pesquisa}

Neste trabalho usamos como corpo de dados a transcrição de seis aulas de genética e exercícios escritos pelos alunos do 30 ano do Ensino Médio. Os dados foram coletados no primeiro semestre de 2008, na Escola de Aplicação da Universidade de São Paulo. Na época da coleta, eu atuava como estagiária de Iniciação Científica pela Faculdade de Educação da Universidade de São Paulo. A sequência didática acompanhada material de análise para três pesquisas: o projeto de doutorado da professora de Biologia, um projeto de mestrado em andamento e o meu projeto de iniciação científica.

Minha participação nas aulas foi neutra, auxiliando nas gravações de áudio e vídeo, junto com o pesquisador do projeto de mestrado em curso. Acompanhamos duas turmas de 3ำ ano do Ensino Médio ao longo do semestre e arquivamos os registros de áudio e vídeo. $\mathrm{O}$ projeto de iniciação científica teve fim no ano de 2009 e tratou sobre o uso de modelos em aulas de ciências como auxiliador à argumentação. 
A professora de Biologia era também aluna de doutorado integrante do laboratório de pesquisa. As discussões quinzenais sobre a argumentação em sala de aula eram embasadas na literatura corrente sobre o assunto e os projetos de pesquisa surgiam influenciados pelas discussões. A professora, naquela época também pesquisadora, teve sua prática didática influenciada pelas leituras e discussões do grupo.

O projeto de pesquisa apresentado neste trabalho de mestrado é resultado da análise posterior da sequência didática e da identificação do potencial que essa sequência tinha para ser analisada. Logo, a construção do projeto foi posterior à coleta de dados. Isso torna o caminho do tratamento e da análise dos dados limitado ao existente e impossibilita algumas abordagens comuns na área de educação, como entrevistas com os sujeitos de pesquisa ou testes pré e pós-sequência.

\section{Situação estudada}

A sequência de interesse se passou na Escola de Aplicação da Universidade de São Paulo. Na ocasião da coleta de dados, a Escola de Aplicação atendia a cerca de 740 alunos distribuídos por todas as séries do ensino básico. Cada nível escolar era composto de duas turmas de aproximadamente 30 alunos cada. A duração normal de cada aula, independente da disciplina, era de 50 minutos e eram ministradas duas aulas semanais de biologia para cada turma.

Registramos uma sequência de aulas de genética no 3o ano do Ensino Médio (Tabela 02), em ambas as turmas (I e II), totalizando aproximadamente 60 alunos. No ensino médio os alunos são responsáveis por se deslocarem até as salas de aula específicas, sendo que cada disciplina tem uma sala própria. A sala de biologia é chamada de sala ambiente, composta por uma parte de sala de aula tradicional (com carteiras enfileiradas de frente para uma lousa) e outra parte com duas bancadas de laboratório, o que permite maior integração entre os ambientes, pois a professora pode mesclar as aulas em ambos os locais sem precisar deslocar os alunos pela escola. As paredes opostas da sala têm lousas, o que permite à professora utilizar recursos visuais em ambos os locais da sala. 
Tabela 02: Sequência de aulas das duas turmas de $3^{\circ}$ ano do Ensino Médio registradas.

\begin{tabular}{|c|c|c|}
\hline Data & № & Conteúdo de aula \\
\hline $02 / 04 / 2008$ & 1 & Texto: “A descoberta da célula". Discussão das questões propostas para casa. \\
\hline 07/04/2008 & 2 & $\begin{array}{l}\text { Discussão sobre o texto (continuação). Discutir a ideia de que todos os seres vivos são } \\
\text { formados por células. }\end{array}$ \\
\hline 09/04/2008 & 3 & $\begin{array}{l}\text { Aula expositiva (em multimídia): ciclo celular, estrutura do núcleo celular, organização dos } \\
\text { cromossomos durante o ciclo celular. }\end{array}$ \\
\hline $14 / 04 / 2008$ & 4 & $\begin{array}{l}\text { Aula expositiva (em multimídia): classificação dos cromossomos, cariótipo e idiograma, } \\
\text { doenças cromossômicas. Exercício para casa: montagem de idiogramas. }\end{array}$ \\
\hline $16 / 04 / 2008$ & 5 & Aula de leitura e discussão: "A descoberta do DNA", estrutura do DNA. \\
\hline $21 / 04 / 2008$ & 6 & Feriado de Tiradentes. \\
\hline 23/04/2008 & 7 & $\begin{array}{l}\text { Aula de leitura e discussão: DNA como material hereditário, por que o DNA foi considerado } \\
\text { o portador das informações hereditárias? }\end{array}$ \\
\hline 28/04/2008 & 8 & $\begin{array}{l}\text { Aula de leitura e discussão: DNA como material hereditário, "por que o DNA foi } \\
\text { considerado o portador das informações hereditárias?"; Aula expositiva (em multimídia): } \\
\text { ciclo celular (fase S, duplicação do DNA). Por que ocorre a duplicação do DNA no ciclo } \\
\text { celular? Por que ocorre a duplicação do DNA na meiose? }\end{array}$ \\
\hline $30 / 04 / 2008$ & 9 & Montagem do modelo estrutural de DNA e RNA. \\
\hline 05/05/2008 & 10 & Aula de revisão. Resolução de dúvidas dos alunos. \\
\hline 07/05/2008 & 11 & Avaliação individual. \\
\hline
\end{tabular}

As aulas de biologia nesse período foram registradas em áudio e vídeo. Em todas as aulas foram utilizadas duas câmeras fixas opostas em uma das diagonais da sala e diversos equipamentos de captação de áudio espalhados por entre as carteiras. As aulas foram transcritas na íntegra por meio dos registros de áudio e vídeo, de forma a garantir uma maior acuidade nas transcrições (Apêndices 02 e 03) ${ }^{1}$. As transcrições foram literais, o mais próximo da linguagem oral usada. Trechos inaudíveis na transcrição foram indicados com a expressão "inaudível" para que fique claro que algo foi dito, mas a qualidade do registro não permitiu a transcrição. A fala muitas vezes é entrecortada, logo usamos “(...)" para indicar longas pausas e reproduzimos as hesitações da professora com as expressões "Éhh" e "Ãhh". O foco das transcrições foi a fala da professora. Optamos pela esquematização em turnos de fala e apresentamos a contagem em minutos de cada aula.

O tema da sequência didática foi citologia, compreendendo desde as funções celulares, o núcleo celular, o ciclo celular, os cromossomos até a estrutura do DNA. O registro das aulas teve início no dia 02/04/2008, quando a professora introduziu o tema citologia e terminou em 05/05/2008, na última aula antes da avaliação individual (ver Tabela 02). As seis aulas escolhidas para análise foram um grupo de aulas de leitura dialogada de um texto formulado pela professora.

\footnotetext{
${ }^{1}$ Nas transcrições, para preservar a identidade dos alunos, todos os alunos do sexo masculino foram renomeados João e todas as alunas do sexo feminino foram renomeadas Maria. Essa escolha metodológica foi feita porque as análises que realizamos neste trabalho não consideraram a fala dos alunos durante as aulas um dado relevante para nossos objetivos.
} 
Estamos interessados nas aulas em que a professora trata da importância e da função do material genético nas células (aulas 5, 7 e 8; Tabela 02). 0 dia 21/04/2008 foi nomeado como aula 6 apesar de ser feriado comemorativo do Dia de Tiradentes, logo, as aulas analisadas são a 5, 7 e 8, mas representam uma sequência direta das aulas das turmas analisadas. Para facilitar a leitura e a diferenciação das aulas analisadas, renomeamos as aulas de interesse dessa pesquisa (Tabela 03).

Tabela 03: Renomeação das aulas de interesse para facilitar a identificação. Cada aula foi ministrada na turma I e na turma II, totalizando seis aulas para as análises aqui propostas.

\begin{tabular}{ll}
\hline Dia da aula e turma & Nome \\
\hline Aula $16 / 04-3^{\circ}$ ano I & $5 \mathrm{I}$ \\
Aula $16 / 04-3^{\circ}$ ano II & $5 \mathrm{II}$ \\
Aula $23 / 04-3^{\circ}$ ano I & $7 \mathrm{I}$ \\
Aula 23/04 $-3^{\circ}$ ano II & $7 \mathrm{II}$ \\
Aula 28/04 $-3^{\circ}$ ano I & $8 \mathrm{I}$ \\
Aula 28/04 $-3^{\circ}$ ano II & $8 \mathrm{II}$ \\
\hline
\end{tabular}

O esquema das aulas é parecido nas duas turmas, mas há pequenas diferenças de organização das aulas devido ao uso do tempo. As aulas foram divididas em etapas para facilitar a identificação dos trechos de interesse para análise (Tabela 04). A aula 5 (tanto na turma I como na turma II) começa com o fechamento da aula anterior. A professora recolhe e corrige oralmente os exercícios que passou para os alunos sobre idiogramas ${ }^{2}$. Após recolher e corrigir oralmente os exercícios, a professora distribui um novo texto aos alunos, intitulado "A descoberta do DNA" (Anexo 01).

O texto composto pela professora era estruturado em três tópicos de frases curtas que faziam referências a diversos eventos históricos acompanhados do ano em que ocorreram, formando uma linha do tempo (Anexo 01), além de sintetizar resultados de experimentos. A elaboração do texto foi a partir do livro didático utilizado naquele ano e de uma apostila do curso de Biologia Molecular para a graduação em Ciências Biológicas da Universidade de São Paulo.

A sua leitura, tanto na aula 51 como na aula 511 é iniciada pela leitura e explicações do item 1 seguida pela leitura e explicações do item 3. O texto é lido pela professora que

\footnotetext{
${ }^{2}$ Idiograma: A representação diagramática do cariótipo de um organismo, conjunto dos cromossomos de um organismo organizados por número, tamanho e forma dos tipos de cromossomos presentes. É utilizado para identificar anormalidades no número ou morfologia dos cromossomos (MCENTYRE e OSTELL, 2006).
} 
completa as informações de cada tópico oralmente. Toda a leitura é feita de forma dialogada, a professora pergunta aos alunos conhecimentos explicados anteriormente e fornece informações novas.

Tabela 04: organização e divisão do tempo nas aulas de interesse. Cada aula é composta de etapas parciais que compõem aulas de 50 minutos. A aula 5I é exceção e apresenta um total de 55 minutos de aula.

\begin{tabular}{|c|c|c|}
\hline Aula & Tempo (minutos) & Fase da aula \\
\hline \multirow[t]{4}{*}{51} & 10 & Correção de exercício - recolhe e corrige em voz alta. \\
\hline & 20 & Leitura de texto - itens 1 e 3. \\
\hline & 5 & Encenação da molécula de DNA pelos alunos. \\
\hline & 20 & Leitura de texto - item 2.1. \\
\hline \multirow[t]{3}{*}{511} & 20 & Correção de exercício - recolhe e corrige em voz alta. \\
\hline & 25 & Leitura de texto - itens 1 e 3. \\
\hline & 5 & Encenação da molécula de DNA pelos alunos. \\
\hline \multirow[t]{2}{*}{ 7I } & 30 & Leitura de texto - item 2.2 . \\
\hline & 20 & Discussão entre os alunos. \\
\hline \multirow[t]{2}{*}{ 7II } & 15 & Revisão de conceitos das aulas anteriores. \\
\hline & 35 & Leitura do texto - item 2. \\
\hline \multirow[t]{3}{*}{81} & 20 & Discussão em sala sobre as respostas dos exercícios. \\
\hline & 10 & Tempo para reformulação das respostas individualmente. \\
\hline & 20 & Início do próximo trecho da sequência didática \\
\hline \multirow[t]{2}{*}{811} & 30 & Discussão da questão em grupos de quatro alunos. \\
\hline & 20 & Discussão em roda sobre as respostas dos exercícios. \\
\hline
\end{tabular}

Após a leitura desses dois tópicos, a professora propõe uma encenação aos alunos. Os alunos se levantam e se deslocam ao outro ambiente da sala de aula. Formam duas filas paralelas e os alunos participam como nucleotídeos de uma molécula de DNA. Nessa fase da aula percebe-se bastante agitação por parte dos alunos. A professora aumenta o tom de voz para ser ouvida, precisa chamar a atenção da turma e acaba explicando apenas para um grupo de alunos mais atentos à sua fala.

A aula 5II acaba logo após a encenação do DNA, enquanto que na aula 5I, após a encenação ainda restam quase 20 minutos da aula. A professora decide seguir com a leitura passando para o item 2.1 do texto. Na leitura desse item a professora explica uma sequência de experimentos de biologia molecular da primeira metade do século XX. A professora, da mesma forma que nos outros itens, intercala a leitura dos tópicos com explicações de cunho histórico e narrativo e com perguntas aos alunos. Ao final da explicação do item 2.1 do texto, a professora propõe uma questão para ser entregue na aula seguinte. A questão proposta 
nesse momento da aula é restrita ao primeiro experimento relacionado ao tema, pois a leitura do texto avançou apenas até ele. Os alunos copiam a questão e a aula acaba.

$\mathrm{Na}$ aula 7I, os alunos chegam e se organizam. A professora comenta que a questão não será entregue naquele momento e retoma a leitura do texto. A professora faz a leitura do texto da mesma forma que na aula anterior, mesclando narrativas com perguntas aos alunos. Após a leitura do item 2.2, a professora propõe uma nova questão, mais geral, que envolve os trechos de todo o item 2. Os alunos são instruídos a se juntarem com até três colegas para discutir e responder uma nova questão, mais abrangente e que envolve os dois experimentos relacionados ao tema. A professora circula entre os grupos e auxilia a discussão dos alunos. Ao final da aula, a professora indica que essa nova questão deve ser respondida individualmente e entregue na aula seguinte pelos alunos.

A aula 7II é diferente da aula 7I devido ao tempo utilizado na aula 5II. A professora lê o item 2 do texto na íntegra e propõe direto a questão mais abrangente aos alunos: "Por que as conclusões dos experimentos 1 e 2 (que o DNA é o princípio transformante e que o DNA do vírus penetra na bactéria) permitem afirmar que o DNA é o portador das informações hereditárias?". Os alunos copiam a questão e têm como tarefa, responder a questão para a aula seguinte.

A aula 81 tem seu início dedicado à discussão da questão. A professora mantém as carteiras em fileiras, mas pergunta aos alunos quem gostaria de ler a questão em voz alta. Alguns alunos leem suas respostas, a professora reexplica alguns conceitos e dá tempo aos alunos para que reformulem suas questões escritas. Após a reformulação das respostas, a professora recolhe os exercícios e muda o assunto da aula, seguindo para o próximo tema da sequência geral.

A aula 811 é inteiramente dedicada à discussão da questão. A professora organiza os alunos em grupos de quatro alunos e dá aproximadamente 30 minutos para que discutam a questão. Após esse tempo, a professora reestrutura a sala em uma grande roda de discussão e chama os alunos pontualmente para mostrarem suas respostas e incita a discussão. Após a discussão a professora indica aos alunos que entreguem suas respostas.

Os exercícios escritos feitos pelos alunos foram recolhidos pela professora e contavam pontos, valiam nota na média do semestre. Estes foram reproduzidos (Anexo 02) para evitar que a análise fosse contaminada por julgamentos subjetivos como: letra, 
tamanho e estado de conservação da folha. Os erros de português (ortografia e gramática) foram mantidos, pois nossa intenção é avaliar exatamente o que foi escrito pelo aluno.

A análise em trabalhos sobre situações de ensino e discurso geram questões metodológicas que vão desde como organizar os dados até como representá-los por meio de inscrições (cf. JIMÉNEZ e DÍAZ 2003). Estamos interessados em três pontos da sequência registrada: as ações pró-argumentação da professora ao longo das aulas de interesse, os argumentos fornecidos pela professora e pelo texto ao longo das aulas e os exercícios escritos entregues pelos alunos à professora ao final das aulas de interesse.

Análises

Ao fim do processo de seleção dos dados a serem analisados neste projeto somam-se seis aulas de 50 minutos cada, o texto original usado pela professora em sala durante as aulas e as respostas dos alunos à questão proposta pela professora. As aulas foram transcritas a partir dos arquivos de áudio e vídeo, conforme apresentaram melhor qualidade. A transcrição das aulas (Apêndices 02 e 03) foi organizada em uma tabela dividida em minutos. As falas foram separadas em turnos, estabelecidos de acordo com a pausa entre falas ou mudança de locutores. As falas da professora foram identificadas com a letra $\mathrm{P}$ e as falas de alunos foram identificadas com a letra A. Uma coluna de observações compõe a tabela e indica informações sobressalentes que podem ser de interesse. Por fim, a coluna ações pró-argumentação identifica quais as falas da professora foram consideradas ações pró-argumentação.

O texto fornecido em aula não sofreu nenhuma mudança estrutural, gramatical ou conceitual para que fosse analisado (Anexo 01). As respostas dos alunos foram reproduzidas em meio digital para evitar parcialidades nas análises, a gramática, ortografia e concordância do texto foram mantidas conforme seus originais. As respostas são apresentadas no Anexo 02 e são acompanhadas de suas reestruturações segundo o modelo de Toulmin (2006).

As transcrições das aulas serviram a dois objetivos: a identificação das ações próargumentação da professora e os argumentos construídos por ela durante as aulas. $O$ texto original lido em aula foi usado para identificar os argumentos fornecidos por esse texto nas 
aulas. As respostas escritas pelos alunos foram usadas na identificação de argumentos e sua complexidade estrutural e conceitual. A relação entre argumentos fornecidos e produzidos foi feita posteriormente às análises dos argumentos.

a. Ações pró-argumentação

Para o primeiro objetivo deste trabalho, identificar ações pró-argumentação da professora, quantificamos quais ações a professora apresentou segundo a tabela (página 23) criada por Simon, Erduran e Osborne (2006). As falas da professora foram analisadas para identificar se ela agia segundo os códigos propostos pelos autores. Cada fala foi contabilizada como uma ocorrência, podendo haver mais de uma ocorrência de cada código durante o tempo de uma aula (Apêndices 02 e 03). Apresentamos nos resultados deste trabalho a quantificação das ações identificadas seguidas por exemplos de cada uma das ações.

b. Argumentos fornecidos

Para o segundo objetivo deste trabalho, identificar com o modelo de Toulmin os argumentos fornecidos pela professora e pelo texto lido em sala durante as aulas analisadas, quantificamos e qualificamos os argumentos fornecidos. Os dados representativos para esse trecho da análise são as transcrições das falas da professora (Apêndices 02 e 03) durante as aulas da sequência e o texto usado durante a mesma.

Os argumentos produzidos pela professora foram identificados na leitura das transcrições. Toda afirmação defendida por dado ou justificativa foi considerada um argumento, porém, afirmações sem justificativa não foram contabilizadas. A identificação dos argumentos fornecidos pela professora foi individual e seguiu o padrão indicado na literatura de identificar a afirmação principal como conclusão e a partir dela elencar o que seriam dados, garantias ou apoios (cf. ERDURAN; SIMON; OSBORNE, 2004). 
Os argumentos da professora foram categorizados por tema e quantificados. Os temas são os assuntos sobre os quais a professora fala em seus argumentos. Por exemplo, diferenciamos momentos em que a professora fala sobre a estrutura molecular do DNA de momentos em que a professora fala sobre a função do DNA na célula. Os dois assuntos citado são diferentes, logo, formam categorias temáticas diferentes.

Essa categorização permite explorar os trechos das explicações em que a professora forma argumentos (Apêndice 04). A divisão por temas nos permite identificar qual assunto é mais estruturado em forma de argumentos e que tipo de informação entra na aula da professora como afirmação baseada em evidência. Essa categorização também permite a relação entre os temas que a professora fala e os temas que o aluno usa em suas respostas.

A mesma categorização por temas foi seguida na análise do texto. Os argumentos do texto foram identificados da mesma maneira que os argumentos da professora e os temas dos argumentos encontrados foram incorporados à categorização por temas feita para as falas da professora. Temas presentes no texto e ausentes nas falas da professora nos fizeram adicionar categorias para podermos, da mesma forma, identificar quais informações foram veiculadas em forma de afirmações baseadas em evidências.

Apresentamos nos resultados a quantificação dos argumentos da professora separados por categoria e por turma, além de um exemplo de cada categoria. Os argumentos do texto são apresentados na íntegra nos resultados, uma vez que o texto é curto.

c. Argumentos produzidos

Para o terceiro objetivo deste trabalho, identificar com o modelo de Toulmin os argumentos produzidos pelos alunos nas respostas escritas ao exercício proposto pela professora, os dados representativos são as respostas a uma pergunta após a sequência didática que os alunos deveriam fazer individualmente e entregar para a professora. Ignoramos a avaliação feita pela professora, uma vez que a avaliação naquele momento tinha objetivos diferentes dos objetivos de análise presentes. A avaliação escolar tem múltiplas funções (KRASILCHIK, 2008) e não cabe a nós, neste momento, discutirmos as notas dadas pela professora naquela ocasião. 
Em alguns trabalhos de pesquisa da área que apresentam análises de textos produzidos pelos alunos os autores indicam o uso aliado das transcrições com os áudios e vídeos para identificar, no tom de voz, a força persuasiva das afirmações (ERDURAN; SIMON; OSBORNE, 2004; SIMON; ERDURAN; OSBORNE, 2006). Na sequência didática analisada, as discussões de aula fazem parte do processo de formação das respostas e podem não ser coerentes com a resposta final escrita pelos alunos, portanto, as discussões de sala de aula não serão levadas em consideração na análise das respostas dos alunos.

Analisamos, portanto, as resposta escritas dos alunos (Anexo 02). Essa análise é vantajosa, pois a linguagem escrita tende a ser mais objetiva quando comparada com a linguagem oral (OLIVEIRA e CARVALHO, 2005). Nas discussões orais a fala é entrecortada, com sobreposições dos colegas e do professor, enquanto que na linguagem escrita o aluno faz um monólogo pensado, mais elaborado (CARLSEN, 2007). Além disso, o trabalho individual é mais fácil de ser examinado, pois o "argumento" ${ }^{3}$ construído pelo aluno é individual, evitando discutir aqui se é possível ou não a construção de argumentos em grupo ou apenas sozinho.

As respostas dos alunos foram reestruturadas segundo o padrão de argumento de Toulmin (2006) para que fossem analisadas. A reestruturação das respostas em argumentos no formato de Toulmin (2006) significa a transformação das sentenças que compõem a resposta do aluno na ordem dos elementos propostos pelo autor.

Em um trabalho de revisão sobre as diferentes análises de argumentação, Sampson e Clark (2008) analisam um argumento hipotético sob diferentes óticas de pesquisa. Fica claro nesse trabalho que existe uma reestruturação da fala dos alunos em argumentos no formato de Toulmin e que essa reestruturação respeita as relações sintáticas indicadas pelo aluno. Optamos pela mesma abordagem e reestruturamos os argumentos de acordo com as relações explicitamente marcadas no texto do aluno.

A estruturação dos argumentos levou em consideração as relações sintáticas presentes no texto dos alunos. Só estruturamos as frases em dado e conclusão caso fosse identificada uma relação de causa e consequência. Relações desse tipo são marcadas por conjunções específicas, por exemplo: porque, já que, pois, uma vez que, visto que ou

\footnotetext{
${ }^{3}$ A palavra argumento foi colocada entre aspas nesse contexto para deixar explícito que os alunos não tomam conhecimento do padrão de argumento usado na análise. Porém, argumentar é uma ação maior, na qual justificamos nossas decisões e atitudes. Nesse trecho, a palavra argumentar tem esse sentido.
} 
outras ${ }^{4}$. Quando houve enumeração de fatos sem nenhuma relação de causa e efeito explicitada pelo uso das conjunções corretas, não reestruturamos o argumento.

Esse processo de reestruturação é bastante interpretativo (JIMÉNEZ e DÍAZ, 2003; SIMON; ERDURAN; OSBORNE, 2006; VONAUFSCHNAITER et al., 2008), podendo gerar dúvidas quando feito individualmente. Tais confusões são explicitadas em exercícios plenamente gramaticais, pois em português, assim como no inglês, uma mesma sentença pode servir a mais de uma função - dado, garantia ou apoio (TOULMIN, 2006 pp.142). Alguns autores se utilizam de pessoas que atuam como codificadores independentes e comparações entre as classificações dos codificadores (ERDURAN; SIMON; OSBORNE, 2004), porém, para este trabalho, fizemos uma codificação em dupla.

A codificação em dupla foi consensual, ou seja, os codificadores discutiram cada argumento formulado até que chegassem a um acordo sobre a estruturação do argumento. Este método permite aos codificadores discutirem suas escolhas, possibilitando um refinamento na análise (cf. DAWSON e VENVILLE, 2009). Os argumentos foram analisados independentemente por dois codificadores, duas vezes (codificação, discussão, nova codificação após um mês) Os argumentos discrepantes foram discutidos até um consenso. Apesar desse e outros trabalhos (cf. SIMON; ERDURAN; OSBORNE, 2006) mostrarem uma porcentagem de similaridade, porém, não há explicação sobre como essa similaridade é medida. Dessa forma, optamos por utilizar apenas a fase consensual.

O processo de reestruturação das respostas dos alunos ocorreu de maneira diferente da reestruturação dos argumentos da professora e do texto. Os argumentos em textos mais longos apresentam mais de uma afirmação e são considerados mais subjetivos. Diferentes trabalhos apresentam propostas de codificação (SAMPSON e CLARK, 2008) para textos como as respostas dos alunos.

A reestruturação era iniciada sempre a partir da identificação da conclusão do argumento (cf. ERDURAN; SIMON; OSBORNE, 2004), de forma a clarificar o papel das outras sentenças de um mesmo parágrafo da resposta em torno da afirmação. Os dados geralmente são precedidos no argumento por palavras como 'por que', 'uma vez que' e 'como'. Já as garantias, quando presentes, são frases ou sentenças que ligam os dados à conclusão (SIMON; ERDURAN; OSBORNE, 2006). Como afirmado anteriormente, adaptamos o modelo proposto por Toulmin (2006). Consideramos o modelo mais simplificado (Figura

\footnotetext{
${ }^{4}$ Para maiores esclarecimentos sobre as relações sintáticas buscadas no texto, indicamos Neves (2000).
} 
03, pp. 20), em que garantia e apoio aparecem unidos em um elemento chamado justificativa.

Para facilitar a leitura, criamos alguns códigos de estruturação dos argumentos. Trechos entre colchetes significam adições nossas ao texto do aluno para que este se torne inteligível. Quando cortamos o texto do aluno, colocamos o símbolo '(...)' indicando tal corte. Finalmente, trechos em negrito são identificações pontuais de erros conceituais (Figura 04).

$$
\begin{aligned}
& \text { D - [Dado que] a bactéria S estava morta } \\
& \text { (...) Houve uma transformação fazendo } \\
& \text { com que as bactérias } R \text { virassem } S \text {. }
\end{aligned}
$$

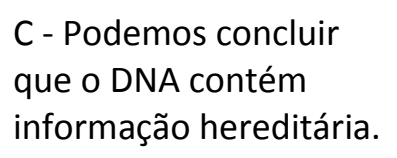
que o DNA contém informação hereditária.

Figura 04:Argumento hipotético para ilustrar os códigos usados. Informações entre colchetes são inserções nossas, o símbolo (...) indica corte na escrita do aluno e trechos em negrito apontam erros conceituais.

Com o intuito de validar a reestruturação dos argumentos, fizemos um esforço de contextualização de nossas análises (BRICKER e BELL, 2008). Após a reestruturação dos argumentos dos alunos, as relações conceituais existentes em tais argumentos foram colocadas à prova. Se um argumento fosse composto por dado e conclusão, mas o dado proposto não fosse coerente conceitualmente com a conclusão que ele tentava defender, esse argumento foi considerado inválido em nossa análise. Se o argumento fosse composto por dado, justificativa e conclusão, tanto a relação entre dado e conclusão quanto a relação entre dado e justificativa foi colocada à prova. Todo argumento, mesmo reestruturado, correu então o risco de ser considerado inválido conceitualmente.

A proposta acima é uma tentativa de resolver uma demanda na área de pesquisa em ensino de ciências: a necessidade de desenvolvimento de estudos que busquem criar e aperfeiçoar as devidas adaptações do padrão para os contextos de salas de aula de ciências (NASCIMENTO e VIEIRA, 2008). Entendemos que, com essa forma de análise, nos livramos do risco de usar o modelo de Toulmin como um quebra-cabeça e passamos a considerar apenas os argumentos que condizem com o contexto de sua produção.

Após as duas primeiras etapas de análise, direcionamos nossa atenção ao conteúdo da questão que gerou os exercícios. Esta apresenta uma resposta esperada, ou seja, é possível indicar quais alunos entenderam a pergunta e souberam respondê-la, 
diferentemente de trabalhos que analisam questões sócio científicas (temas controversos e que não apresentam resposta única, cf. DAWSON e VENVILLE, 2009; GRACE, 2009; ALBE, 2008).

Partindo do enunciado da pergunta: "Por que as conclusões dos experimentos 1 e 2 (que o DNA é o princípio transformante e que o DNA do vírus penetra na bactéria) permitem afirmar que o DNA é o portador das informações hereditárias?", os alunos deveriam entender que "o DNA é o portador das informações hereditárias" é uma afirmação que deve ser justificada com base nos "experimentos 1 e 2 ". Os alunos que conseguissem entender essa indicação do enunciado teriam entendido o exercício proposto pela professora (Tabela 05).

Tabela 05: chaves dicotômicas que ilustram a categorização dos argumentos produzidos pelos alunos em suas respostas.

\section{USO DE LINGUAGEM CIENTÍFICA}

1. Compreensão da questão:

Argumento não apresenta conclusão esperada pelo enunciado

Argumento apresenta conclusão esperada pelo enunciado

Argumento que não responde a pergunta

\section{Natureza do dado:}

Citação simples do experimento 1 e/ou 2; Narrativa do experimento 1

e/ou 2; Apresentação dos resultados do experimento 1 e/ou 2

Qualquer explicação diferente das opções acima aluno não cumpre a tarefa

3. Presença de justificativa:

Argumento sem justificativa

Argumento com justificativa

4. Validade do argumento:

Argumento válido

argumento simples e pouco complexo

Argumento inválido argumento com relações conceituais erradas

5. Validade do argumento:

Argumento válido

argumento que contempla a tarefa

Argumento inválido argumento considerado incorreto

\section{COMPREENSÃO DA TAREFA}

1. Execução da tarefa:

Argumento que apresenta apenas um dos experimentos como evidência para a afirmação

Argumento que apresenta os dois experimentos como evidências para a

afirmação

2. Quantidade de argumentos na resposta:

Aluno que escreve apenas um argumento

aluno que não contempla plenamente a tarefa

Aluno que escreve mais de um argumento

3. Soma dos argumentos de um mesmo aluno:

Apenas um argumento responde a tarefa

aluno que não contempla plenamente a tarefa

A somatória dos argumentos embasa a conclusão esperada nos dois experimentos 
Identificamos nos argumentos dos alunos o conteúdo das diferentes conclusões e separamos aquelas que correspondiam ao enunciado da pergunta. Consideramos que os alunos que mostrassem em suas conclusões a informação sobre "o DNA ser o portador das informações hereditárias" compreenderam parcialmente a tarefa.

Relacionamos o conteúdo apresentado por esses alunos nos dados para defender tal conclusão. Consideramos que o grupo de alunos que conseguiu articular nos dados as informações sobre os "experimentos 1 e 2 " compreenderam plenamente a tarefa.

Por fim, analisamos dentre os alunos que entenderam a tarefa qual a profundidade de articulação dos conhecimentos, pois entendemos que um aluno que cita o experimento articula menos informações do que aquele que consegue mostrar os resultados dos experimentos. Investigamos também quais alunos usaram garantia, como indício de melhor apropriação dos conceitos científicos pelo aluno; quais alunos estabelecem argumentos válidos, pois estamos em um contexto específico e o campo de argumentos permitido é restrito.

d. Relação entre argumentos fornecidos e produzidos

Finalmente, para o quarto objetivo deste trabalho, relacionar os argumentos fornecidos em aula (professora e texto) com os argumentos produzidos pelos alunos, os dados de interesse são todos os argumentos analisados: os da professora, os do texto e os dos alunos. Gostaríamos de verificar se há coincidências entre os argumentos fornecidos e os construídos e se é possível criar relações entre eles.

O professor atua como criador e gerenciador dos discursos implementados nas aulas de ciências (JIMÉNEZ E DÍAZ, 2003). De acordo com autores e pesquisas recentes, a argumentação deve estar presente em sala de aula (ERDURAN; SIMON; OSBORNE, 2004) e a prática desse discurso depende do tipo de instrução dada em sala de aula (JIMÉNEZ; PÉREZ; CASTRO, 1998). Dessa forma, podemos concluir que os discursos conduzidos pelo professor são importantes para o desenvolvimento desse discurso por parte dos alunos.

A partir do momento que alguns autores entendem que o discurso argumentativo deve ser explicitamente ensinado em sala de aula (SIMON; ERDURAN; OSBORNE, 2006), e a 
partir das evidências trazidas por alguns trabalhos sobre a influência conceitual e argumentativa que o professor tem sobre os alunos (DAWSON e VENVILLE, 2009) é justificável analisar os argumentos fornecidos em aula e os argumentos produzidos pelos alunos na tentativa de identificar similaridades. O padrão de Toulmin (2006), a partir do estabelecimento de elementos do argumento, possibilita a comparação entre as falas do professor e os argumentos expressos pelos alunos ao longo dos exercícios (NASCIMENTO e VIEIRA, 2008).

Os argumentos expostos em aula foram relacionados com os argumentos construídos nas respostas dos alunos. Usamos para essa comparação as categorias temáticas criadas para os argumentos da professora e do texto. As conclusões dos argumentos fornecidos foram comparadas com as conclusões dos argumentos produzidos pelos alunos. Seguida essa fase, as categorias temáticas dos argumentos da professora foram procurados em qualquer elemento dos argumentos dos alunos. As ocorrências foram listadas e quantificadas (Apêndice 05). As categorias fornecidas que aparecem com mais frequência nos argumentos dos alunos são destacadas nos resultados, como indício de informações mais relevantes. 


\section{4- Resultados}

a. Ações pró-argumentação

Seguindo a categorização feita neste trabalho (Tabela 01, página 23) foram identificados seis códigos pró-argumentação nas falas e ações da professora ao longo das seis aulas analisadas. Os códigos identificados pertencem às categorias Falar e escutar, Posicionamento e Justificar com evidências. No total das seis aulas a professora somou 78 ações pró-argumentação, sendo que a maior parte das ações se enquadra na categoria Justificar com evidências (Tabela 06).

Tabela 06: Número de ocorrências dos códigos pró-argumentação nas falas e ações da professora.

\begin{tabular}{lll}
\hline Categoria de ação pró-argumentação & Código de ação pró-argumentação & Número de ocorrências \\
\hline Falar e escutar & Encorajar a ouvir & 2 \\
Posicionar-se & Valorizar posições diferentes & 1 \\
Justificar com evidências & Conferir evidências & 23 \\
& Fornecer evidências & 46 \\
& Incitar o uso de justificativa & 4 \\
& Enfatizar a justificativa & 2 \\
\hline
\end{tabular}

As ações mais frequentes da professora em sala de aula se encaixam nos códigos conferir e fornecer evidências, que ocorrem em todas as seis aulas analisadas. Durante a leitura do texto, a professora enfatiza como os cientistas usam as evidências para construir conclusões e os resultados de seus experimentos. Essas ações estão relacionadas com a leitura do texto, que a professora faz em voz alta completando as informações do texto com explicações conceituais.

Os outros códigos apareceram com menor frequência, pontuais em alguma das aulas. Valorar posições diferentes, incitar e enfatizar justificativas são identificados também relacionados à leitura e discussão do texto de base para as aulas da sequência, enquanto que encorajar a ouvir acontece exclusivamente na última aula, em que as turmas discutem em um grande grupo sobre a questão proposta. É importante ressaltar que todos os códigos foram identificados em ambas as turmas (Tabela 07). 
Tabela 07: Exemplos de falas da professora que foram considerados códigos e categorias na proposta de Simon, Erduran e Osborne (2006).

\begin{tabular}{|c|c|c|c|}
\hline Fala & Código & Categoria & Aula - Linha \\
\hline $\begin{array}{l}\text { "A composição química e a resistência à pepsina. Então } \\
\text { vamos primeiro analisar a resistência à ação da pepsina. } \\
\text { O que é que é a pepsina?" }\end{array}$ & Fornecer evidências & Justificar com evidências & $5 I-60$ \\
\hline $\begin{array}{l}\text { “Naquela época, já se conhecia, estavam começando a } \\
\text { entender as proteínas. Se encontravam proteínas em } \\
\text { várias estruturas celulares, né? Então, sabia-se que a } \\
\text { proteína estava na membrana sabiam que existiam } \\
\text { várias proteínas no citoplasma da célula, né? Proteínas } \\
\text { estavam em todos os lugares da célula. Então, inclusive, } \\
\text { acreditava-se que eram as proteínas, né? Elas fazem } \\
\text { tudo, elas estão em todas as estruturas celulares, então, } \\
\text { talvez também sejam as proteínas as responsáveis por } \\
\text { guardar a informação hereditária, a informação que } \\
\text { passa (...) de uma geração para outra, né?” }\end{array}$ & $\begin{array}{l}\text { Enfatizar as } \\
\text { justificações }\end{array}$ & & $5 I I-58$ \\
\hline $\begin{array}{l}\text { "Então, com essas ideias em mente (...). Na verdade, } \\
\text { naquela época também não davam muita importância } \\
\text { para o núcleo da célula. Eles acreditavam que o núcleo } \\
\text { não tinha muita função, né? Mas (...) esse pesquisador } \\
\text { aqui começou a pesquisar o composto do núcleo e até } \\
\text { achou que descobriu uma nova substância que não era } \\
\text { proteína, por quê? Por que não era a proteína?" }\end{array}$ & $\begin{array}{l}\text { Incitar a } \\
\text { argumentação dos } \\
\text { alunos }\end{array}$ & & $511-59$ \\
\hline $\begin{array}{l}\text { "Que a amilase vai destruir o amido. Então,se for amido. } \\
\text { Se quando eu pegar esse princípio e juntar com } \\
\text { bactérias R, a bactéria R vai se transformar em S?" }\end{array}$ & $\begin{array}{l}\text { Evidenciar } \\
\text { justificação }\end{array}$ & & $51-341$ \\
\hline $\begin{array}{l}\text { “Então isso é um ponto. Outro ponto que a Maria falou } \\
\text { lá é a composição química. Composição química ácida, } \\
\text { rica em fósforo. Proteína tem pouco fósforo, não tem } \\
\text { fósforo. Tem nitrogênio, mas fósforo é pobre em } \\
\text { fósforo. E essa substância tinha fósforo. Desprovida de } \\
\text { enxofre e proteínas geralmente tem bastante (?) } \\
\text { enxofre. Então também a composição química, os } \\
\text { elementos químicos encontrados nessa substância são } \\
\text { diferentes (?) das proteínas, mesmo assim, muitos } \\
\text { pesquisadores não acreditam nesse (inaudível) Richard. } \\
\text { E falaram: "não, isso são proteínas que estão } \\
\text { contaminadas com grupos fosfatos, né”?" }\end{array}$ & $\begin{array}{l}\text { Valorizar posições } \\
\text { diferentes }\end{array}$ & Posicionamento & $5 I-77$ \\
\hline $\begin{array}{l}\text { "Bom pessoal, quero que cada grupo exponha } \\
\text { rapidamente pra gente poder ter a discussão, né? É (...) } \\
\text { João começa." }\end{array}$ & Encorajar a ouvir & Falar e escutar & $8 I 1-16$ \\
\hline
\end{tabular}


b. Argumentos fornecidos

\section{Argumentos da professora}

Ao longo das aulas a professora constrói uma série de relações causais entre evidências e conclusões. Enumeramos um total de 73 argumentos nas seis aulas analisadas, dos quais 16 apresentaram justificativa. No total, os argumentos puderam ser agrupados em 24 categorias temáticas (Tabela 08; Apêndice 04). Demonstramos, por meio da categoria 1, como a reconstrução das falas da professora foi feita e como categorizamos os argumentos (ver Apêndice 04).

A categoria 1 agrupa argumentos sobre doenças cromossômicas. Tais afirmações só aparecem, pois a professora corrige alguns exercícios das aulas anteriores no começo da sequência alvo. Esta categoria é composta de quatro argumentos, sendo apenas um na turma I.

Da frase construída originalmente pela professora: "Síndrome de Down! Tinha um que era Síndrome de Down, que tinha três cromossomos 21, estava sobrando um!" a reestruturação em proposição resultou em: [Dado] que tinha três cromossomos 21, estava sobrando um [cromossomo], [assim], tinha uma que era síndrome de Down.

Tabela 08: Categorias temáticas dos argumentos da professora.

\begin{tabular}{|c|c|c|c|c|}
\hline \multirow[t]{2}{*}{ Categoria } & \multirow[t]{2}{*}{ Tema } & \multicolumn{2}{|c|}{$\begin{array}{l}\text { Número de } \\
\text { ocorrências }\end{array}$} & \multirow[t]{2}{*}{ Exemplo } \\
\hline & & 31 & 311 & \\
\hline 1 & Doenças cromossômicas & 1 & 3 & $\begin{array}{l}\text { [Dado] que tinha três cromossomos } 21 \text {, estava } \\
\text { sobrando um [cromossomo], [assim], tinha uma } \\
\text { que era síndrome de Down. }\end{array}$ \\
\hline 2 & $\begin{array}{l}\text { Natureza da substância identificada na } \\
\text { célula em meados de } 1800\end{array}$ & 1 & 3 & $\begin{array}{l}\text { [Dado] que o composto estava presente no núcleo, } \\
\text { [assim], o pesquisador o chamou de nucleína. }\end{array}$ \\
\hline 3 & $\begin{array}{l}\text { Possibilidade das proteínas serem o } \\
\text { material hereditário }\end{array}$ & 2 & 2 & $\begin{array}{l}\text { [Dado] que tinha proteínas em todos os lugares das } \\
\text { células, [assim], eles começaram a dar muita } \\
\text { importância pras proteínas. }\end{array}$ \\
\hline 4 & $\begin{array}{l}\text { Impossibilidade das proteínas serem o } \\
\text { material hereditário }\end{array}$ & 2 & 3 & $\begin{array}{l}\text { [Dadas] a composição química e a resistência da } \\
\text { substância à pepsina, [assim], podemos concluir } \\
\text { que essa substância é diferente de proteína. }\end{array}$ \\
\hline 5 & $\begin{array}{l}\text { Características moleculares do DNA e } \\
\text { RNA }\end{array}$ & 4 & 7 & $\begin{array}{l}\text { [Dado] que o carboidrato é desoxirribose, [assim], } \\
\text { é DNA. }\end{array}$ \\
\hline 6 & Carboidrato é uma macromolécula & 0 & 1 & $\begin{array}{l}\text { [Dado] que as subunidades do carboidrato são os } \\
\text { polissacarídeos, [assim], os carboidratos são } \\
\text { macromoléculas. }\end{array}$ \\
\hline 7 & $\begin{array}{l}\text { Encenação realizada pelos alunos ao } \\
\text { final da aula } 5\end{array}$ & 2 & 1 & $\begin{array}{l}\text { [Dado] que estão em direções opostas, [assim], } \\
\text { foram chamadas de fitas antiparalelas. }\end{array}$ \\
\hline
\end{tabular}


Nome da molécula de DNA segundo a

fase em que se encontra do ciclo

celular

$9 a$

Sobrevivência da bactéria no corpo do camundongo

$9 b$

Capacidade infectante da bactéria é devida à cápsula de carboidrato

10

11

Relação entre a linhagem de bactéria inoculada no camundongo e a sobrevivência das cobaias

Mecanismo de reprodução da bactéria do corpo do camundongo
Estrutura do vírus bacteriófago

Nome do processo de troca de pedaços do DNA entre bactérias

Natureza do princípio transformante

Mecanismo de reprodução do vírus bacteriófago

Marcação radioativa das estruturas virais

Escolha do DNA como material genético por exclusão de outras substâncias possíveis

Relação entre espécie e número de bases nitrogenadas no material genético

Definição de vírus bacteriófago

Conceito de fecundação

Importância evolutiva da transformação bacteriana

DNA está relacionado às características físicas dos seres vivos

DNA tem as informações hereditárias em bactérias

DNA ser o portador das informações hereditárias em consequência dos experimentos feitos

[Dado] que a célula está na mitose, que é a divisão propriamente dita, [assim], os fios são chamados de cromossomos.

[Dado] que se ela não tem aquela cápsula de carboidratos ela fica mais vulnerável ao ataque das células de defesa do camundongo, [assim], não causa a doença no camundongo

[Dado] que elas [as bactérias S] têm uma cápsula de carboidrato em volta delas, [assim], elas causam pneumonia

[Dado] que ele inoculou os ratinhos com bactérias $S$ vivas, [assim], o ratinho morreu.

[Dado] que a bactéria $S$ se instala ali nas células do sistema respiratório e vai se reproduzindo, a bactéria. E aí, para, nesta reprodução, ela vai aí destruindo aí as células saudáveis do indivíduo, [assim], ela causa pneumonia

1

[Dado] que a bactéria $\mathrm{R}$ foi transformada em $\mathrm{S}$, [assim], eles chamam de transformação bacteriana.

[Dado] que ao colocar protease o princípio transformante continuou ativo, [assim], o princípio transformante não é protease.

[Dado] que o vírus tem uma estrutura tão simples, já que é formado por uma cápsula de proteínas e o DNA no seu interior, [assim], há uma discussão se ele é um ser vivo ou não.

$0 \quad 1$

[Dado] que o vírus não tem nada lá dentro, só o DNA, [assim], ele usa todo o mecanismo da célula da bactéria para sua reprodução.

[Dado] que se marcassem, [assim], poderiam ver o que é que entra na célula da bactéria.

01

20

[Dado] que excluímos as outras substâncias, [assim], o único que pode ser o material genético é o DNA.

[Dado] que a proporção de bases é constante dentro da espécie, [assim], se eu pegar diferentes órgãos ou diferentes células de vários indivíduos da mesma espécie, o número de bases é o mesmo.

[Dado] que vírus bacteriófagos são aqueles que atacam bactérias, [assim], bactérias também são atacadas por vírus.

[Dado] que junta o espermatozoide, junta o óvulo, se juntam, formam a primeira célula do indivíduo, [assim], a informação que gera um novo indivíduo vem dos gametas.

[Dado] que passando o DNA de uma pra outra, ela vai adquirir as características daquele outro DNA, [assim], essa capacidade, lá na origem da vida, que permitiu a diversidade de seres vivos.

[Dado] que o DNA provocou mudanças na própria bactéria, [assim], ele está associado com as características físicas da própria bactéria.

[Dado] que as bactérias filhas pegaram o DNA que conferiu as mesmas características da mãe, [assim], quem tem a informação que passa de uma geração pra outra é o DNA.

[Dado] o experimento, [assim], quem entra na célula e tem a informação para construir novos vírus é o DNA. 
Dos 73 argumentos fornecidos pela professora, 29 foram encontrados na turma I, enquanto que na turma II foram encontrados 44 argumentos. Sobre a natureza dos argumentos, apesar das turmas terem os mesmos conceitos expostos durante as aulas, a turma I não recebeu informações em forma de relações causais para as categorias $6,8,9,11$, 12,15 e 17. Já a turma II não recebeu informações em forma de relações causais para as categorias 18 até 24 .

Dos 73 argumentos fornecidos pela professora, três apresentam conclusão semelhante à conclusão do enunciado da questão feita aos alunos. Nenhum dos três argumentos apresenta justificativa (categorias 17, 23 e 24). Os argumentos apresentam dados com conceitos diferentes entre si, o que justifica a sua classificação em categorias diferentes.

\section{Argumentos presentes no texto lido em aula}

Foram identificados sete argumentos no texto, dentre os quais apenas um apresenta justificativa e um apresenta qualificador. Os argumentos do texto foram classificados segundo as categorias criadas para os argumentos da professora, facilitando assim as análises posteriores sobre os argumentos fornecidos. Dentre os sete argumentos encontrados, quatro foram inseridos nas categorias criadas anteriormente enquanto três não apresentaram categoria equivalente à da fala da professora (Tabela 09). O texto foi distribuído e lido em ambas as turmas.

Tabela 09: Categorias temáticas dos argumentos do texto. As categorias temáticas dos argumentos do texto são as mesmas que as categorias temáticas das falas da professora.

\begin{tabular}{llll}
\hline Categoria & Tema & Frase original do texto & Argumento \\
\hline $\mathbf{3}$ & $\begin{array}{l}\text { Possibilidade das } \\
\text { proteínas serem o } \\
\text { material } \\
\text { hereditário. }\end{array}$ & $\begin{array}{l}\text { Nesta época, as proteínas eram as } \\
\text { melhores candidatas para conterem } \\
\text { as informações genéticas, por sua } \\
\text { impressionante variabilidade de } \\
\text { composição, estrutura e função. }\end{array}$ & $\begin{array}{l}\text { Dado que tinham uma } \\
\text { impressionante variabilidade de } \\
\text { composição, estrutura e função, } \\
\text { assim, as proteínas eram as melhores } \\
\text { candidatas para conterem as } \\
\text { informações genéticas. }\end{array}$ \\
& $\begin{array}{lll}\text { Relação entre a } \\
\text { linhagem de } \\
\text { bactéria inoculada }\end{array}$ & $\begin{array}{l}\text { S vivas - camundongo morre } \\
\text { R vivas - camundongo sobrevive } \\
\text { S mortas pelo calor - camundongo }\end{array}$ & $\begin{array}{l}\text { Dado que S vivas - camundongo } \\
\text { morre; R vivas - camundongo } \\
\text { sobrevive; S mortas pelo calor - }\end{array}$ \\
\hline
\end{tabular}


no camundongo e sobrevive

a sobrevivência das $S$ mortas pelo calor $+R$ vivas cobaias.

13

Natureza do princípio transformante.

16

Marcação

radioativa das

estruturas virais.

A

B

Acuidade do experimento

B

Acuidade do experimento

camundongo morre

Conclusões: bactérias $R$ vivas

haviam sido transformadas em $\mathrm{S}$ por algum tipo de substância ("princípio transformante") liberado pelas bactérias $\mathrm{S}$ mortas.

Em 1944, no laboratório de Avery, isolaram grandes quantidades desse princípio e o trataram com:

Amilase: ele continuava com o princípio transformante;

Proteases: ele continuava com o princípio transformante;

Ribonucleases: ele continuava com

o princípio transformante;

Desoxirribonucleases: ele perdia o princípio transformante.

Conclusões: Substância

transformante é o DNA:

1952 - Alfred Hershey e Martha

Chase marcaram o DNA de vírus

com fósforo radioativo e a

proteínas de vírus com enxofre

radioativo. Verificaram que apenas

o DNA do vírus penetra na bactéria, produzindo em 30 minutos

centenas de outros vírus completos.

Conclusão: A fonte de informações hereditárias é o DNA, pois a partir dele pode ser formado tanto DNA quanto proteínas virais.

Ocorrência in vitro 1944 - Oswald Avery verificou que da transformação a transformação bacteriana ocorria bacteriana também in vitro. Em meios de cultura de bactérias $\mathrm{R}$ misturadas com $\mathrm{S}$ mortas, apareciam bactérias $S$ vivas.

Argumentos contra: a amostra poderia estar contaminada com proteínas e que estas seriam responsáveis pela transformação bacteriana.

Contra-argumento: Em 1952 se conseguiram amostras com apenas 0,02\% de proteínas. camundongo sobrevive; S mortas

pelo calor $+R$ vivas - camundongo

morre, assim, bactérias $R$ vivas

haviam sido transformadas em $\mathrm{S}$ por

algum tipo de substância ("princípio transformante") liberado pelas bactérias $\mathrm{S}$ mortas.

Dado que trataram o princípio transformante com: Amilase: ele continuava com o princípio transformante; Proteases: ele continuava com o princípio transformante; Ribonucleases: ele continuava com o princípio transformante; Desoxirribonucleases: ele perdia o princípio transformante, assim, Substância transformante é o DNA.

Dado que a partir do DNA pode ser formado tanto DNA quanto proteínas virais, assim, A fonte de informações hereditárias é o DNA. Isso pode ser afirmado já que Alfred Hershey e Martha Chase marcaram o DNA de vírus com fósforo radioativo e a proteínas de vírus com enxofre radioativo. Verificaram que apenas 0 DNA do vírus penetra na bactéria, produzindo em 30 minutos centenas de outros vírus completos.

Dado que Em meios de cultura de bactérias $\mathrm{R}$ misturadas com $\mathrm{S}$ mortas, apareciam bactérias $S$ vivas, assim, a transformação bacteriana ocorria também in vitro.

Dado que a amostra poderia estar contaminada com proteínas e que estas seriam responsáveis pela transformação bacteriana, assim, provavelmente, o DNA não é o princípio transformante.

Dado que Em 1952 se conseguiram amostras com apenas $0,02 \%$ de proteínas, a amostra não estava contaminada. 
c. Argumentos produzidos

\section{Análise formal das respostas}

Consideramos que o enunciado da pergunta proposta aos alunos fornecia dado e conclusão de um argumento, cabendo aos alunos ressaltar a justificativa (garantia e apoio) que permitia a ligação entre os dois. A professora, no enunciado da questão pede para o aluno: "[...] mostrar que, tomando-se aqueles dados como ponto de partida, é apropriado e legítimo passar dos dados à alegação ou conclusão apresentada" (TOULMIN, 2006; Pp. 141).

Uma vez que a pergunta fornecida fora: "Por que as conclusões dos experimentos 1 e 2 (que o DNA é o princípio transformante e que o DNA do vírus penetra na bactéria) permitem afirmar que o DNA é o portador das informações hereditárias?", esperavam-se respostas que afirmassem "o DNA é o portador das informações hereditárias dadas as conclusões dos experimentos 1 e 2 (que o DNA é o princípio transformante e que o DNA do vírus penetra na bactéria)" e apresentassem conceitos veiculados sobre ambos os experimentos para justificar a afirmação.

Dentre os 60 alunos das duas turmas do 3o ano do Ensino Médio, um total de 35 alunos entregou o exercício. Das respostas analisadas, foram estruturados 62 argumentos (Tabela 10), sendo que 29 eram compostos apenas de dado e conclusão. Um total de 33 argumentos apresentou alguma justificativa. Dos 62 argumentos encontrados, 15 apresentaram qualificador enquanto nenhum argumento apresentou refutação (Figura 05).

Tabela 10: Número de argumentos produzidos individualmente pelos 35 alunos da amostra. As respostas que não resultaram em argumentos são compostas de muitos erros conceituais e de escrita (Alunos 16, 19, 21 e 33).

\begin{tabular}{ll}
\hline № de argumentos construídos & $\begin{array}{l}\text { № de alunos que construiu } \\
\text { argumentos }\end{array}$ \\
\hline $\mathbf{0}$ & 4 \\
$\mathbf{1}$ & 13 \\
$\mathbf{2}$ & 9 \\
$\mathbf{3}$ & 6 \\
$\mathbf{4}$ & 3 \\
\hline
\end{tabular}




\section{Análise conceitual das respostas}

Em diferentes momentos os alunos foram capazes de articular suas ideias possibilitando a formação de argumentos, porém as informações veiculadas eram conceitualmente equivocadas. Para evitar uma análise descontextualizada (BRICKER e BELL, 2008), avaliamos a correção conceitual dos argumentos produzidos após a formatação dos argumentos. Dessa forma, contornamos uma das críticas comuns ao modelo de argumentação de Toulmin (2006) feitas por alguns trabalhos da área (cf. ERDURAN; SIMON; OSBORNE, 2004; SIMON; ERDURAN; OSBORNE, 2006; VONAUFSCHNAITER et al., 2008).

Dos 62 argumentos construídos (Anexo 02), 48 apresentaram relações conceituais corretas (77\%), ou seja, podem ser considerados argumentos científicos (Figura 05; Apêndice 01). Diferenciamos os alunos que apresentaram justificativa em seus argumentos daqueles que apresentaram apenas dado e conclusão. Comparamos dentro do grupo de alunos que escreveu argumentos com dado e conclusão (D-C), quantos alunos escreveram argumentos com qualificador e quantos alunos escreveram argumentos válidos. A mesma coisa foi feita com os argumentos que apresentaram justificativa (D-J-C). As barras do gráfico apresentamse dobradas para permitir tal comparação, logo, o número total de argumentos produzidos não corresponde à somatória das barras do gráfico.

\section{Distribuição dos elementos nos argumentos}

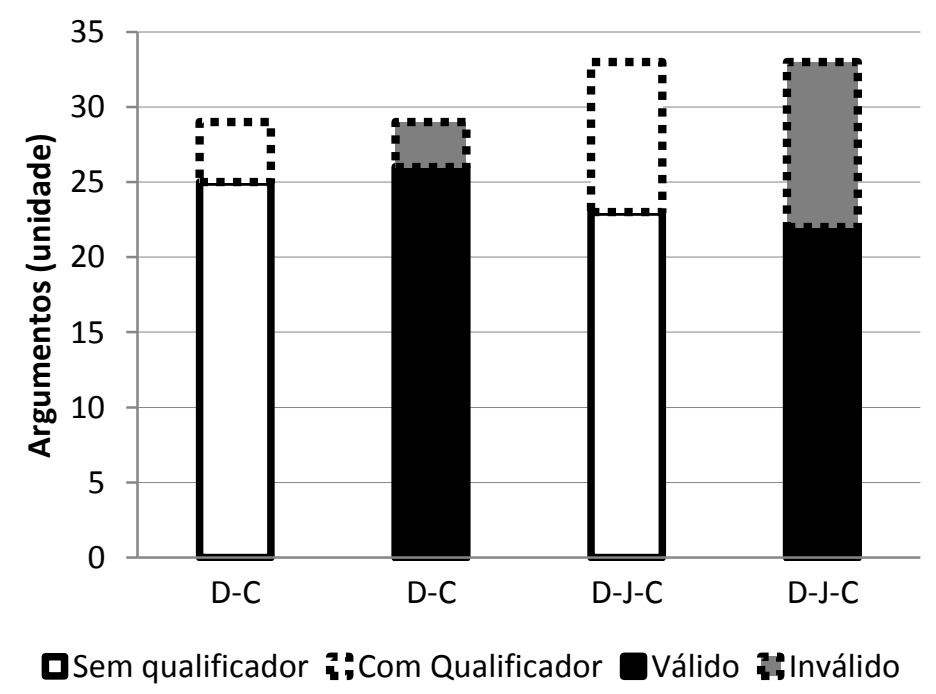

Figura 05: Número de ocorrência e validade conceitual dos argumentos de acordo com a apresentação de justificativas. D: dado; C: conclusão; J: justificativa. O gráfico permite a comparação entre os alunos que escreveram argumentos com qualificador com aqueles que escreveram argumentos válidos. 
Após a análise formal dos argumentos e sua validação conceitual, prosseguimos com a verificação de quais alunos conseguiram entender e cumprir com a tarefa. Dentre os 35 alunos, consideramos que 30 deles entenderam que era necessário defender a conclusão "o DNA é o portador das informações hereditárias". Ou seja, 30 alunos escreveram pelo menos um argumento com afirmação semelhante a do enunciado no lugar de conclusão. Houve variação entre as conclusões. Algumas indicavam o DNA como portador da informação hereditária, enquanto outras indicavam o DNA como transmissor dessa informação. Ambas foram consideradas coerentes com o enunciado.

Dentre os 30 alunos que apresentaram pelo menos um argumento com a conclusão esperada em suas respostas, selecionamos aqueles que entenderam também que era necessário embasar a conclusão a partir de informações dos dois experimentos explicados em aula. Identificamos que 18 citaram os experimentos, nove narraram os experimentos e 12 declararam as conclusões dos experimentos como dados que asseguravam a conclusão. Porém, alguns alunos comentaram apenas do 1 ou do 20 experimento. A questão era clara e pedia que os alunos usassem ambos os experimentos para embasar a conclusão. Logo, alunos que falaram de apenas um dos argumentos, foram identificados como alunos que conseguiram cumprir parcialmente a tarefa.

Dentre os 18 alunos que citaram os experimentos, seis alunos não apresentaram justificativa, ou seja, apresentaram uma cópia do enunciado da questão. Um total de 12 alunos apresentou justificativas para passar da citação dos experimentos para a conclusão esperada, mas apenas sete usaram conceitos científicos corretamente (válidos: 3, 4, 5, 11, 17, 23 e 34). O aluno 26 escreveu três vezes o mesmo argumento, porém se limita a repetir o enunciado sem construir justificativa. Dos 18 que citam os experimentos, apenas dois justificaram o argumento com informações de ambos os experimentos (4 e 11).

Dentre os sete alunos que em algum de seus argumentos apresentaram como dado a narrativa dos experimentos, apenas dois alunos (9 e 12) narraram ambos os experimentos, enquanto os outros alunos narraram apenas o 1 응 ou o 2 experimento. $\mathrm{O}$ aluno 12 consegue articular todas as informações em um único argumento, enquanto os alunos 1 e 9 usaram mais de um argumento para responder à questão. O aluno 13 apresentou duas conclusões para o mesmo conjunto de dados quando afirma que "o DNA é o portador e transmissor das características hereditárias", porém, limitou-se a narrar o experimento 1.0 aluno 32, apesar de articular informações de ambos os experimentos, apresentou erros conceituais ao 
justificar o 1 을 experimento, ou seja, só conseguiu justificar corretamente o 2ํe experimento como justificativa da conclusão.

Dentre os oito alunos que em algum de seus argumentos apresentaram como dado diretamente os resultados dos experimentos, apenas dois conseguiram usar informações dos dois experimentos em suas respostas (8 e 18), enquanto os outros evidenciaram apenas o resultado do 1 o ou do 2 o experimento. Alguns alunos $(7,8,18$ e 28$)$ construíram dois argumentos para colocar separadamente os resultados dos experimentos 1 e 2 , porém, os alunos 7 e 28 apresentam um de seus argumentos inválido, o que faz com que consideremos que esses dois alunos só conseguiram explicar um dos experimentos como evidência para a conclusão esperada.

$\mathrm{O}$ aluno 1 usou dois argumentos em sua resposta. No primeiro argumento, narrou o primeiro experimento corretamente e no segundo argumento, se utiliza das conclusões do segundo experimento. Sendo assim, esse aluno também cumpre a tarefa. Ou seja, sete alunos $(1,4,8,9,11,12,18)$ conseguiram cumprir plenamente a tarefa. Aqueles que não conseguiram fazer isso em um só argumento construíram mais de um argumento, mesmo que com conclusões diferentes da esperada pelo enunciado, justificando a informação de que "o DNA é o portador das informações hereditárias".

Como exemplo, demonstramos o argumento construído a partir da resposta do aluno 12: “[Dado que] No primeiro experimento as bactérias vivas adquirem o DNA da[s] bactérias mortas e suas filhas nascem com suas novas características. Já no segundo experimento foi observado que é o DNA do vírus que entra na célula e que produz novos vírus. Assim, pode se observar que é o DNA que contém as informações hereditárias. [Porque] [o DNA] é quem faz com que sejam reproduzidos novos indivíduos, com as características do progenitor (informações hereditárias)."

Dentre os 30 alunos que entenderam a instrução (incluindo os sete alunos que completaram a tarefa), 18 apresentaram mais de um argumento, sendo que 12 deles apresentaram pelo menos um argumento de conclusão diferente da conclusão proposta pelo enunciado. Dentre os alunos que escreveram argumentos com outras conclusões, a conclusão mais frequente foi "as proteínas poderiam ser o fator transformante". Essa conclusão foi classificada juntamente com outras duas que diziam respeito apenas ao primeiro experimento. Dentre os 12 alunos que escreveram argumentos de conclusão alternativa, 10 argumentos diziam respeito ao 10 experimento. 
d. Relação entre os argumentos fornecidos e produzidos

Analisamos as respostas dos alunos e identificamos 37 argumentos nos quais aparecem informações relacionadas às mesmas categorias temáticas identificadas nos argumentos fornecidos pela professora ou pelo texto (Apêndice 05). Dentre os 37, sete argumentos usam tais informações como conclusão dos argumentos construídos enquanto que a maioria dessas informações foi usada pelos alunos exclusivamente como dados e/ou justificativas, somando 30 argumentos.

Dessa forma, as afirmações defendidas nos argumentos da professora assumem papéis diferentes nos argumentos dos alunos, ora como dado, ora como justificativa. Há uma mudança no nível de importância das informações utilizadas em sala de aula uma vez que categorias temáticas que representavam argumentos completos foram incorporadas aos argumentos dos alunos como fatos ou embasamento teórico.

Alguns dos argumentos dos alunos apresentaram mais de uma categoria de informação fornecida pela professora ou pelo texto (Tabela 11). Um total de 10 alunos agrupa diferentes informações fornecidas e as utiliza como dados e justificativas para seus argumentos, ou seja, conseguem identificar a importância dos conceitos fornecidos pela professora ou pelo texto como embasamento para seus argumentos. A informação utilizada mais vezes dentro desse grupo é de que a capacidade infectante da bactéria se deve à sua cápsula de carboidratos.

Tabela 11: Descrição das múltiplas categorias de informações fornecidas pela professora ou pelo texto nos argumentos dos alunos.

\begin{tabular}{lll}
\hline Aluno $_{\text {(argumento) }}$ & Categorias de informação usadas & Local das informações no argumento do aluno \\
\hline $\mathbf{2}_{(1)}$ & $9 b, 10,12, \mathrm{~A}$. & Dado \\
$\mathbf{3}_{(1)}$ & $5,9 a, 12,13, \mathrm{~A}$. & Justificativa \\
$\mathbf{5}_{(1)}$ & $9 \mathrm{~b}, 10$. & Justificativa \\
$\mathbf{7}_{(1)}$ & $11,12$. & Dado e justificativa \\
$\mathbf{9}_{(2)}$ & $9 \mathrm{~b}, 12$. & Dado e justificativa \\
$\mathbf{1 4}_{(\mathbf{2})}$ & $10,12,13$. & Dado e justificativa \\
$\mathbf{2 0}_{(1)}$ & $5,9 \mathrm{~b}, 10,13$. & Dado \\
$\mathbf{2 4}_{(1)}$ & $5,9 \mathrm{~b}, 10$. & Dado \\
$\mathbf{3 2}_{(1)}$ & $11,16$. & Justificativa \\
$\mathbf{3 5}_{(1)}$ & $9 \mathrm{~b}, 10$. & Justificativa \\
\hline
\end{tabular}


Das várias informações fornecidas pela professora, algumas apareceram em mais argumentos que outras. Dentre as quais:

- Informação sobre a marcação radioativa permitir a visualização de qual estrutura viral entra na célula da bactéria (categoria 16), citada por 11 argumentos. Essa categoria de argumentos é citada pela professora em ambas as turmas e é encontrada no texto;

- Informação sobre a definição de transformação bacteriana (categoria 12), citada por nove argumentos. Essa categoria de argumento é apresentada formalmente na aula da turma II, mas das 11 ocorrências, duas são da turma I;

- Descrição do experimento da pneumonia e camundongos (categoria 10), citada por oito argumentos. Essa categoria de argumentos é citada pela professora em ambas as turmas e é encontrada no texto;

- Relação entre a presença de uma cápsula de carboidrato e a capacidade infectante da bactéria (categoria 9b), citada por sete argumentos. Essa categoria de argumento é apresentada formalmente na aula da turma II, mas das sete ocorrências, uma é da turma I;

- Relação entre os nomes "desoxirribose" e "DNA" (categoria 5), citada por cinco argumentos;

- Descrição sobre a natureza química do princípio transformante (categoria 13), citada por cinco alunos. Essa categoria de argumentos é citada pela professora em ambas as turmas e é encontrada no texto. 


\section{5- Discussão}

a. Ações pró-argumentação

Entendemos que as ações pró-argumentação (encorajar a ouvir, valorar posições diferentes, conferir evidências, fornecer evidências, incitar o uso de justificativa, enfatizar a justificativa) identificadas na fala da professora condizem com o objetivo da aula de explicar o desenvolvimento da ciência na área da genética em meados do século XX. As aulas não têm como objetivo a discussão de um tema controverso, nem a encenação de um júri, situações em que o debate é mais opinativo e tem caráter social mais presente. Esse desenho de aula permitiria, além dos códigos registrados neste trabalho, o uso de explicações processuais sobre o uso de evidências e seu papel na ciência (Categoria Avaliação de argumentos) ou ainda a definição e exemplificação explicita de argumentos (Categoria Saber o que significa argumento).

Segundo Kuhn (2007), as ações pró-argumentação relacionadas a um problema de referência proporcionariam um aumento no aprendizado dos alunos, mas apesar da situação estudada não ter sido desenhada dessa forma, foram identificadas ações pró-argumentação da professora em todas as aulas. A estrutura das aulas e do texto permitiram a explicação da construção de conhecimentos científicos a partir de dois exemplos históricos de experimentos em biologia. Os conceitos subentendidos na sequência eram a estrutura e a composição molecular das moléculas de DNA e RNA e a função celular do DNA nos seres vivos. Mas além desses conceitos, a professora inseriu conceitos epistemológicos e históricos em sua aula ao destacar experimentos e evidenciar as conclusões desses experimentos. Dessa forma, podemos afirmar que a professora demonstrou a ciência como uma tarefa humana, da mesma forma que indicam Dawson e Venville (2009).

A professora também guiou a aula de forma mais dialógica, fazendo perguntas aos alunos e dedicando tempos relativamente grandes das aulas para discussões em pequenos grupos ou entre toda a sala. Segundo Simon e Johnson (2008), esse tipo de prática colabora para o desenvolvimento de outros conhecimentos, como o relacionamento interpessoal, o raciocínio crítico e a argumentação. A prática de discussão em sala de aula deve ser 
aumentada e essa sequência pode ser considerada um bom exemplo de uso extenso da discussão, ao contrário do que tem sido relatado na literatura, que aponta que aulas de discussão tomam apenas $2 \%$ do currículo anual (OSBORNE; ERDURAN; SIMON, 2004).

Muita expectativa tem sido colocada sobre as novas propostas didáticas das ciências, porém, além de ainda não termos achado uma metodologia canônica eficaz para todas as ciências e situações (MARTIN e HAND, 2009), a discussão sobre o que queremos ensinar de e sobre ciências não indica uma única metodologia possível (CARVALHO, 2004). O papel da mediação do professor também é crucial e o sucesso de uma sequência didática sempre depende das ações do professor em sala de aula. Isso faz com que cada sequência se modifique de acordo com o profissional que a aplica e nos leva a achar que não haverá sequência canônica que possa ser aplicada por um técnico e que o trabalho pedagógico depende de profissionais bem formados para atuarem em sala de aula.

Com os resultados aqui expostos, nos aproximamos dos autores que entendem que deixar o raciocínio científico claro durante as aulas pode ajudar os alunos a entenderem a lógica da prática científica (McNEILL, 2009). Não é só a prática da ciência que faz alguém entender como ela funciona. A exemplificação de como ela fora construída ao longo do tempo, sua evolução enquanto prática social são elementos que podem ser adicionados à fala do professor e a exercícios teóricos implementados em sala de aula.

b. Argumentos fornecidos

Tanto a professora como o texto lido em sala de aula proporcionam poucos argumentos bem justificados aos alunos durante as seis aulas analisadas. Martin e Hand (2009) sugerem que é comum a falta de prática do professor em promover a argumentação e a descrença da sua importância em sala de aula. O professor deve explicitar e explicar argumentos em aula como forma de exemplos para os alunos se basearam.

Simon e Johnson (2008) indicam que o aprendizado pedagógico também não é linear e o professor deve correr riscos em sua prática. Os autores sugerem que a prática reflexiva é auxiliada quando o professor interage com outros trocando experiências. A análise dessa situação não se encerra em uma crítica à prática pedagógica desse profissional naquele 
momento, mas deve ser fonte de reflexão e desenvolvimento da prática pedagógica, que sem mantém em processo de adaptação às diferentes situações e alunos.

McNeill (2009) relaciona o tipo de instrução do professor e o ganho no aprendizado dos alunos. Apesar de o trabalho citado apresentar um desenho experimental diferente do apresentado aqui, ficam os mesmos indícios de que a instrução direta de evidências, afirmações e raciocínio científico ajuda os alunos a entenderem ciências, já que os argumentos selecionados na fala da professora e no texto trazem, juntos, afirmações e evidências que concordam com o indicado na pesquisa desse autor.

c. Argumentos produzidos

A análise foi composta de diferentes fases com o intuito de contextualizar os argumentos produzidos pelos alunos. Dos 62 argumentos produzidos 48 foram válidos, sendo que metade da amostra total apresentou argumentos justificados. Ou seja, 48 argumentos continham informações científicas corretas. O número de argumentos justificados ou válidos pode ser considerado bastante alto se comparado com outros trabalhos da área. Sasseron e Carvalho (2008) consideram satisfatórias as afirmações que são ligadas a justificativas, assim, consideramos nossos dados satisfatórios.

Apesar da sequência analisada não fazer parte de uma sequência de investigação, fica o indício de que é possível proporcionar a oportunidade de argumentar em aulas com métodos e objetivos diversificados, tornando o ensino da argumentação uma prática mais constante nas aulas de ciências. Isso inova as pesquisas sobre argumentação na área, que preconizam atividades específicas (ex. inquiry, resolução de problemas) para o desenvolvimento da argumentação dos alunos. Entendemos que uma situação comum às salas de aula pode também ser estimuladora para a argumentação.

Outro fator que pode ter contribuído para a construção de tantos argumentos nas respostas analisada, foi a etapa de discussão entre alunos antes da entrega do exercício. Nessa discussão não havia a visão hegemônica da ciência expressa pela fala do professor, quando este ministra instruções diretas, o que permite um diálogo aberto entre os alunos (OSBORNE; ERDURAN; SIMON, 2004). 
Diferente de situações abertas em que diferentes conclusões são possíveis a partir de um mesmo conjunto de dados (ex. JIMÉNEZ; PÉREZ; CASTRO, 1998; ERDURAN; SIMON; OSBORNE, 2004; VONAUFSCHNAITER et al., 2008), entendemos a situação estudada permitia uma única conclusão, dada pela professora no enunciado (DNA é o portador das informações hereditárias). Em outras palavras, a questão proposta pela professora era: explique por que o DNA é o princípio transformante. Segundo o modelo de argumentação de Toulmin, argumentamos quando justificamos uma afirmação (TOULMIN, 2006; Pp. 18). Desse modo, ao pedir que o aluno justificasse uma afirmação, a professora pedia, em outras palavras, que o aluno argumentasse em favor de tal afirmação, apresentando dados, garantias e apoios para a conclusão a ser defendida.

Nessa etapa de análise pudemos perceber um funil. Dos 35 alunos da amostra, 30 conseguiram entender a tarefa proposta pela professora, mas apenas nove conseguiram cumpri-la. Apenas nove dos 35 alunos analisados conseguiram unir habilidades de escrita e competências conceituais para respondê-la. Dissemos que 30 alunos compreenderam a tarefa, pois conseguiram identificar no enunciado a conclusão esperada e os dados que deveriam ser explicados, porém, a maioria dos alunos repetiu o enunciado ou forneceu informações parciais para responder a questão. Dos 35 alunos, 13 apresentaram erros conceituais que invalidaram seus argumentos. Entendemos que nossos dados indicaram dois processos: os alunos conseguiram argumentar cientificamente, mas não conseguiram articular todos os conhecimentos necessários para cumprir a tarefa proposta. Ou seja, eles souberam falar ciência, porém não atingiram seu nível máximo de excelência.

Russel (1983) comenta que a presença do qualificador e da refutação não são prérequisitos para a construção do argumento. Erduran e colaboradores (2004) comentam que a presença dos refutadores é aumentada em situações controversas. Outros trabalhos afirmam ainda que quando os alunos respondem a perguntas diretas, não existe oportunidade para a manifestação de refutações (DAWSON e VENVILLE, 2009; KUHN, 2010). Como o caso estudado possibilitava uma única resposta, nossos resultados concordam com a literatura no que diz respeito ao baixo número de argumentos com qualificadores e à ausência de refutações nos argumentos.

Os argumentos produzidos apresentaram apenas dados e justificativas e apenas 15 argumentos apresentaram qualificador. Não identificamos os elementos mais complexos do modelo de argumentação de Toulmin (2006) (NASCIMENTO e VIEIRA, 2008). Dados similares 
são relatados amplamente na literatura. Segundo Sampson e Clark (2008), os alunos tendem a contar apenas com os dados para suportar suas conclusões ou ainda fazem muitas afirmações sem nenhum embasamento (dado ou justificativa). Porém, discordamos dos mesmos autores quando estes reduzem o sucesso ou fracasso dos alunos em argumentar à natureza da atividade didática preparada. A afirmação carrega em si a ideia de que uma metodologia de ensino por si só é garantia de alcance dos objetivos propostos.

Como foi dito anteriormente, a linguagem argumentativa é gradativa depende de prática (SIMON; ERDURAN; OSBORNE, 2006; SIMON e JOHNSON, 2008), portanto, não podemos esperar que uma atividade isolada durante o Ensino de Ciências faça com que o aluno dê um salto linguístico e conceitual equivalente a alguns anos escolares. Trabalhos como o de Osborne e colaboradores (2004), mostram que há melhora na argumentação dos alunos após um período de aulas com objetivo específico de estimular a argumentação.

Se considerarmos que a ciência apresenta uma linguagem peculiar, devemos possibilitar aos alunos que pratiquem essa linguagem, desafiando-os a justificar resultados a partir de teorias aceitas (LEMKE, 1990; OLIVEIRA e CARVALHO, 2005). Para essa tarefa ser cumprida, o professor deve estimular os alunos a interpretarem as informações relevantes em um texto ou uma discussão, encorajá-los a escutar a opinião dos colegas para que possa contra argumentar, promover discussões e proporcionar aos alunos os conceitos relevantes nessas discussões (CARVALHO, 2008; SIMON; ERDURAN; OSBORNE, 2006).

No sentido de atenuar as críticas à complexidade dos argumentos escritos pelos alunos, Bricker e Bell (2008) argumentam que no dia-a-dia podemos encontrar argumentos com poucos elementos, pois os falantes podem subentender que os conceitos são bem conhecidos entre os interlocutores, fazendo-se desnecessária a explicitação de todos os elementos do argumento.

Houve grande dificuldade em determinar dados, garantias e apoios e entendemos que isso se deva à escrita confusa dos alunos, com conectivos aleatórios (p.ex. os alunos utilizam conjunções de causa em frases que não são causais). Os alunos construíram relações aditivas e enumeraram fatos e justificativas sem elencar sintaticamente qual era a causa e qual era o efeito em suas respostas. Segundo Sampson e Clark (2008), diversos trabalhos da área relatam que os comentários feitos pelos alunos podem frequentemente ser classificados em múltiplas categorias (cf. ERDURAN; SIMON; OSBORNE, 2004; NASCIMENTO e VIEIRA, 2008;). 
Como citado anteriormente (CLARK e SAMPSON, 2008), as análises apresentadas em cada artigo publicado são diferentes, o que torna a comparação entre os resultados dificultada. Além disso, a confusão causada no momento de definir cada elemento dos alunos torna as análises parcialmente subjetivas, uma vez que depende de cada pesquisador como os textos serão encaixados no modelo de Toulmin (2006). Corremos o risco de, sob a ótica de cada pesquisador, rotular os alunos como fracassados ou extremamente habilidosos em ciências (SAMPSON e CLARK, 2008).

Enfrentamos essa dificuldade de análise, mas ao modificar o modelo de Toulmin para uma forma mais simplificada, a diferenciação entre dados e justificativas ficou facilitada. $A$ união das categorias problemáticas do modelo argumentativo de Toulmin (2006) já foi relatada anteriormente (SADLER e FOWLER, 2006). Uma vez que os alunos não aprenderam o modelo de argumentação de Toulmin (2006) especificamente, acreditamos que a divisão entre garantias e apoios seria desnecessária e apenas dificultaria a análise do discurso dos alunos em aulas de ciências.

A verificação da correção conceitual dos argumentos nos permitiu superar uma análise descontextualizada e mais criticável. Validamos os argumentos que falavam sobre ciência, falavam sobre o tema proposto em aula e identificamos os argumentos que respondiam à tarefa específica. Conforme Bricker e Bell (2008) discutem, esse tipo de análise demonstra que a ferramenta de argumentação proposta por Toulmin (2006) não foi utilizada de modo vazio, como se fosse uma régua, mas foi considerada na totalidade da obra, identificando o papel de cada afirmação no texto e considerando seu contexto.

Da mesma forma que não seria possível defendermos que um jogador deve ser escalado para a seleção de futebol a partir do timbre de sua voz, não poderíamos considerar válidos argumentos que defendem que o DNA é o portador das informações hereditárias a partir de um depoimento de um físico que explica a teoria gravitacional. A contextualização de nossa análise nos permitiu selecionar apenas os argumentos que apresentavam relação com um campo específico da ciência, a genética.

Os resultados aqui apresentados também nos permitem olhar para a prática argumentativa como algo maior do que nas aulas de ciências. Uma vez que os alunos conseguiram formar argumentos, mas não conseguiram articular conceitos, devemos nos perguntar se a habilidade argumentativa que apresentaram é fruto das aulas de ciências ou de toda a prática escolar dos alunos. Sendo assim, não podemos afirmar que apenas um tipo 
de prática pedagógica favorece os argumentos, nem tampouco afirmar que as aulas de ciências são um espaço decisivo para o aprendizado da argumentação.

d. Relação entre argumentos fornecidos e produzidos

A tentativa de relacionar os argumentos da professora e dos alunos não possibilitou análises estatísticas. Identificamos que as informações dos argumentos da professora são utilizados pelos alunos como dados ou justificativas. Isso indica que a fala da professora em forma de argumentos a serem aceitos são aceitos pelos alunos como verdades.

Os alunos se apropriam das falas da professora para embasar outras conclusões, como se a informação sofresse uma mudança de papel. Porém, outras informações, não veiculadas na forma de argumento, foram assimiladas nas respostas dos alunos, portanto, não conseguimos afirmar se o uso dessas informações é dependente da forma como são veiculadas em aula.

Algumas categorias temáticas fornecidas em aula foram usadas com maior frequência pelos alunos. Porém, não conseguimos afirmar se tais informações foram mais frequentes por serem mais simples, por terem sido comentadas em aula um maior número de vezes ou se há algum outro motivo para tais informações terem sido usadas com maior frequência.

Essa análise não foi encontrada em outros trabalhos da área. Entendemos que é necessário um desenho experimental mais direcionado para esse fim, bem como um método de análise que permita dizer se os argumentos fornecidos em aula são significativamente relevantes para a aquisição de conceitos pelos alunos. 


\section{6- Conclusão}

A análise das ações pró-argumentação da professora nos leva a relatar que é possível, em aulas com poucas atividades práticas de ciências, aproximar os alunos da linguagem argumentativa das ciências e estimulá-los a se apropriarem dessa linguagem. O professor, à frente de sua sala, deve ter como objetivo clarificar o que é um argumento e demonstrá-lo o maior número de vezes possível durante suas explicações científicas, mesmo que durante suas aulas teórico-explicativas.

A análise dos argumentos fornecidos pela professora e pelo texto nos leva a entender que há pouca explicitação de argumentos, o que pode deixar o aluno sem exemplos de como argumentar. Se a linguagem científica é difícil e demanda prática, o professor deve servir de exemplo para que seus alunos consigam se apropriar gradativamente dessa linguagem.

A análise das respostas dos alunos ao exercício proposto em sala de aula pela professora nos levou a crer que os alunos são capazes de montar argumentos válidos e metade da amostra apresenta argumentos justificados, o que nos faz considerá-los de nível satisfatório. Porém, com a categorização feita das respostas pudemos identificar que apenas uma minoria dos alunos consegue articular todos os conceitos necessários para cumprir a tarefa plenamente.

Ou seja, apesar de demonstrarem que reconhecem o tipo de atividade e tentarem respondê-la, o que indica um conhecimento razoável sobre argumentação, os alunos não conseguem articular os conhecimentos corretos em seus argumentos para responderem à questão. Esse resultado se mostra interessante se considerarmos que a atividade, diferente da maioria das pesquisas feitas na área, era de caráter estritamente científico e não apresentava controvérsia.

Foi possível encontrar coincidências entre os argumentos fornecidos em aula e os argumentos produzidos pelos alunos, indicando uma mudança no valor atribuído às informações. Enquanto a professora defende suas afirmações, os alunos as utilizam com um valor de verdade. Faltam-nos dados para indicar que tais coincidências representam uma relação causal e o avanço nas pesquisas da área pode nos prover um desenho experimental que nos permita estabelecer relações causais entre o conteúdo exposto pela professora e a sua apropriação pelos alunos. 
A estruturação das respostas em argumentos facilita a visualização de erros conceituais e linguísticos cometidos pelos alunos. Sugerimos o treino e o uso da ferramenta de argumentação de Toulmin (2006) pelos professores do Ensino Médio como forma de aprimorar a linguagem argumentativa dos alunos e facilitar o aprendizado de conceitos científicos. 


\section{Bibliografia}

ALBE, V. When Scientific Knowledge, Daily Life Experience, Epistemological and Social Considerations Intersect: Students' Argumentation in Group Discussions on a Socio-scientific Issue. Research in Science Education. 38:67-90. 2008.

AULER, D.; DELIZOICOV, D. Alfabetização científico-tecnológica para quê? Ensaio: pesquisa em educação em ciências. 3: 105-115. 2001.

BRICKER, L. A.; BELL, P. Conceptualizations of Argumentation From Science Studies and the Learning Sciences and Their Implications for the Practices of Science Education. Science Education. 92:473-498. 2008.

BYBEE, R.; McCRAE, B.; LAURIE, R. PISA 2006: An assessment os scientific literacy. Journal of research in science teaching. 46: 865-883. 2009.

CAPECCHI, M. C. V. M.; CARVALHO, A. M. P.; SILVA, D. Relações Entre o Discurso do Professor e a Argumentação dos Alunos em uma Aula de Física. Ensaio: Pesquisa em Educação em Ciências. 2: 1-15. 2002.

CARLSEN, W. S. Language and science learning. In: Handbook of research on science education. S.K. Abell; N.G. Lederman. Lawrence Erlbaum. 1a edição. 2007.

CARVALHO, A. M. P. Critérios estruturantes para o ensino de ciências. In: CARVALHO, A. M. P. (org). Ensino de Ciências: unindo a pesquisa e a prática. São Paulo. Pioneira Thomson Learning. 2004.

CARVALHO, A. M. P. Habilidades de Professores Para Promover a Enculturação Científica. Contexto \& Educação. 22: 25-49. 2008.

CAZELLI, S.; FRANCO, C. Alfabetismo científico: novos desafios no contexto da globalização. Ensaio: Pesquisa em Educação em Ciências. 03: 1-18. 2001.

CHAMIZO, J. A. G. Las aportaciones de Toulmin a La enseñanza de las ciencias. Enseñanza de las ciências. 25. 2006.

CHANG, S. N.; CHIU, M. H. Lakatos' Scientific Research Programmes as a Framework for Analysing Informal Argumentation about Socio-scientific Issues. International Journal of Science Education. 30: 17531773. 2008.

CLARK, D. B.; SAMPSON, V. Assessing Dialogic Argumentation in Online Environments to Relate Structure, Grounds, and Conceptual Quality. Journal of Research in Science Teaching. 45: 293-321. 2008.

COFFIN, C.; O'HALLORAN, K. A. Argument reconceived? Educational Review. 61: 301-313. 2009.

DAWSON, V.; VENVILLE, G. J. High-school Students' Informal Reasoning and Argumentation about Biotechnology: An indicator of scientific literacy? International Journal of Science Education. 31: 14211445. 2009.

DRIVER, R.; NEWTON, P.; OSBORNE, J. Establishing the Norms of a Scientific Argumentation in Classrooms. Science Education. 84:287-312. 2000.

ERDURAN, S.; SIMON, S.; OSBORNE, J. TAPping into argumentation: developments in the application of Toulmin's argument pattern for studying science discourse. Science education. 88: 915-933. 2004.

GIL-PÉREZ, D.; GUISASOLA, J.; MORENO, A.; CACHAPUZ, A.; CARVALHO, A. M. P.; TORREGROSA, J. M. SALINAS, J.; VALDÉS, P.; GONZÁLES, E.; DUCH, A. G.; DUMAS-CARRÉ, A.; TRICÁRICO, H.; GALLEGO, R. Defending constructivism in science education. Science \& Education. 11: 557 - 571. 2002.

GRACE, M. Developing High Quality Decision-Making Discussions About Biological Conservation in a Normal Classroom Setting. International Journal of Science Education. 31: 551-570. 2009.

GUTIÉRREZ, A. La evaluación de las competencias cientificas en PISA: perfiles en los estudiantes iberoamericanos. Alambique. 57: 23-31. 2008.

HENAO, B. L.; STIPCICH, M.S. Educación en ciencias y argumentación: la perspectiva de Toulmin como posible respuesta a las demandas y desafíos contemporáneos para la enseñanza de las Ciencias Experimentales. Revista Electrónica de Enseñanza de las Ciencias. 7: 47-62.2008.

HURD, P. H. Scientific literacy: new minds for a changing world. Science Education. 82: 407-416. 1998. 
JIMÉNEZ, M. P. A.; DÍAZ, J. B. Discurso de aula y argumentación en la clase de ciencias: cuestiones teóricas y metodológicas. Enseñanza de las Ciencias. 21: 3. 2003.

JIMÉNEZ, M. P. A.; PÉREZ, V. A.; CASTRO, C.R. Argumentación en el laboratorio de Física. Atas do VI EPEF. Florianópolis. SC. 1998.

KISCHNER, P. A.; SWELLER, J.; CLARK, R. E. Why minimal guidance during instruction does not work: an analysis of the failure of constructivist, discovery, problem-based, experimental, and inquiry-based teaching. Educational Psychologist. 41: 75-86. 2006.

KRASILCHIK, M.; MARANDINO, M. Ensino de ciências e cidadania. Editora Moderna. São Paulo. 2007.

KRASILCHIK, M. Prática de Ensino de Biologia. Editora da Universidade de São Paulo. São Paulo. 4a edição. 2008.

KUHN, D. Is direct instruction an answer to the right question? Educational psychologist. 42:109-113. 2007.

KUHN, D. Teaching and Learning Science as Argument. Science Education. 1-15. 2010.

LATOUR, B.; WOOLGAR, S. A vida de laboratório: a produção dos fatos científicos. Relume Dumará. Rio de Janeiro. 1997.

LEE, M. H.; WU, Y. T.; TSAI, C. C. Research Trends in Science Education from 2003 to 2007: A content analysis of publications in selected journals. International Journal of Science Education. 31: 1999-2020. 2009.

LEMKE, J. L. Talking science: language, learning and values. Norwood, New Jersey: Ablex Publishing Corporation. 1990.

MAMEDE, M.; ZIMMERMANN, E. Letramento Científico e CTS na formação de professores para o ensino de ciências. Enseñanza De Las Ciencias. Número extra. VII Congreso. 2005.

MARTIN, A. M.; HAND, B. Factors Affecting the Implementation of Argument in the Elementary Science Classroom. A Longitudinal Case Study. Research in Science Education. 39: 17-38. 2009.

McENTYRE, J.; OSTELL, J. The NCBI Handbook. National Library of Medicine. NCBI. 2006.

McNEILL, K. Teachers' Use of Curriculum to Support Students in Writing Scientific Arguments to Explain Phenomena. Science Education. 93: 233-268. 2009.

MORTIMER, E. F.; SCOTT, P. Atividade discursiva nas salas de aula de ciências: uma ferramenta sociocultural para analisar e planejar o ensino. Investigações em Ensino de Ciências. 7: 283 - 306. 2002.

MORTIMER, E. F. Construtivismo, mudança conceitual e ensino de ciências: para onde vamos? Investigações em Ensino de Ciências. 1: 20-39. 1996.

MUNFORD, D.; LIMA, M. C. C. Ensinar ciências por investigação: em quê estamos de acordo? Ensaio: Pesquisa em Educação em Ciências. 9: 72-89. 2009.

NASCIMENTO, S. S.; VIEIRA, R. D. Contribuições e limites do padrão de argumento de Toulmin aplicado em situações argumentativas de sala de aula de ciências. Revista Brasileira de Pesquisa em Educação em Ciências. 8. 2008.

NEVES, M. H. M. Gramática de usos do português. Editora Unesp. São Paulo. 2000.

NEWTON, P.; DRIVER, R.; OSBORNE, J. The place of argumentation in the pedagogy of school science. International Journal of Science Education. 21: 553-576. 1999.

NORRIS, S. P.; PHILLIPS, L. M. How literacy in its fundamental sense is central to scientific literacy. Science Education. 87: 224-240. 2003.

ORGANISATION FOR ECONOMIC CO-OPERATION AND DEVELOPMENT. PISA 2006: Science Competencies for Tomorrow's World. Paris. OECD publishing. 2007.

OlIVEIRA, C. M. A.; CARVALHO, A. M. P. Escrevendo em aulas de ciências. Enseñanza de las ciencias. Número extra. VII Congreso. 2005.

OROFINO, R. P.; CHERNICHARO, P.; TONIDANDEL, S. M. R.; TRIVELATO, S. L. F. Ánálise da argumentação em uma atividade de biologia no ensino médio. VII Enpec - Encontro Nacional de Pesquisa em Educação em Ciências. 2009.

OSBORNE,J.; ERDURAN,S.; SIMON, S. Enhancing the Quality of Argumentation in School Science. Journal of Research in Science Teaching. 41: 994-1020. 2004.

RUSSELL, T. L. Analysing arguments in science classroom discourse: Can teachers' questions distort scientific authority? Journal of Research in Science Teaching. 20: 27-45. 1983. 
SADLER, T. D.; FOWLER, S. R. A Threshold Model of Content Knowledge Transfer for Socioscientific Argumentation. Science Education. 90: 986-1004. 2006.

SAMPSON, V.; CLARK, D. B. Assessment of the Ways Students Generate Arguments in Science Education: Current Perspectives and Recommendations for Future Directions. Science Education. 92: 447-472. 2008.

SANTOS, W. L. P. Educação científica na perspectiva de letramento como prática social: funções, princípios e desafios. Revista brasileira de educação. 12: 474-550. 2007.

SASSERON, L. H.; CARVALHO, A. M. P. Almejando A Alfabetização Científica No Ensino Fundamental: A Proposição e A Procura De Indicadores Do Processo. Investigações em ensino de ciências. 13: 333-352. 2008.

SIMON, S.; JOHNSON, S. Professional Learning Portfolios for Argumentation in School Science. International Journal of Science Education. 30: 669-688. 2008.

SIMON, S.; ERDURAN, S.; OSBORNE, J. Learning to Teach Argumentation: Research and development in the science classroom. International Journal of Science Education. 28: 235-260. 2006.

SOARES, M. Letramento: um tema em três gêneros. Autêntica. Belo Horizonte. 1998.

TOULMIN, S. Os usos do argumento. Martins Fontes. São Paulo. 2006.

VILLANI, C. E. P.; NASCIMENTO, S. S. A Argumentação e o Ensino DE Ciências: Uma Atividade Experimental no Laboratório Didático de Física do Ensino Médio. Investigações em Ensino de Ciências. 8: 187-209. 2003.

VONAUFSCHNAITER, C.; ERDURAN, S.; OSBORNE, J.; SIMON, S. Arguing to learn and learning to argue: case studies of how students' argumentation relates to their scientific knowledge. Journal of research in science teaching. 45: 101-131. 2007.

YORE, L. D.; HAND, B. Epilogue: Plotting a Research Agenda for Multiple Representations, Multiple Modality, and Multimodal Representational Competency. Research in Science Education. 40: 93-101. 2010.

ZEMBAL-SAUL, C. Learning to teach elementary school science as argument. Science education. 93: 687719. 2009. 


\section{Anexos}

Anexo 01 - Texto utilizado nas aulas

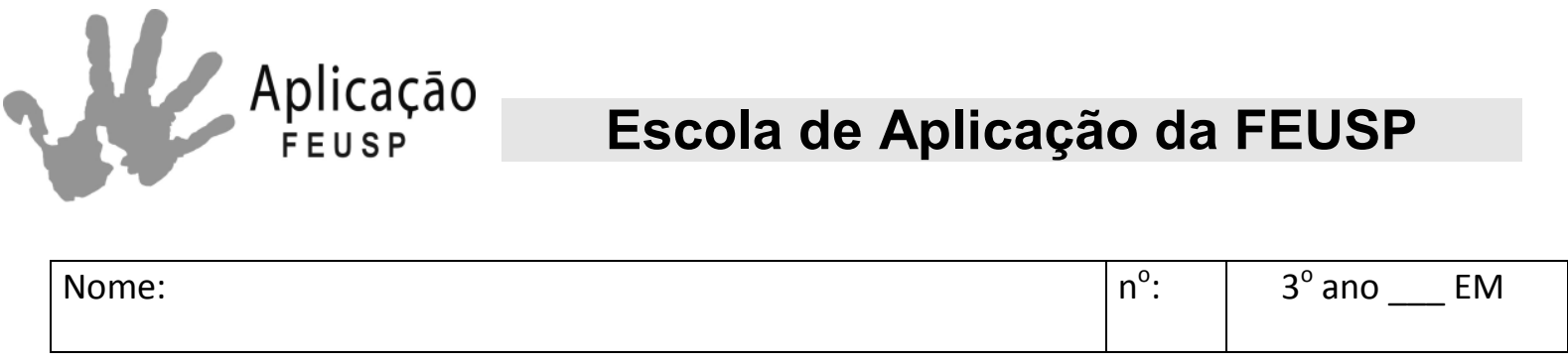

\section{A descoberta do DNA}

\section{Determinação dos componentes do núcleo}

1869 - Johann Miescher: identificou em núcleos de glóbulos brancos um composto de natureza ácida, rico em fósforo e nitrogênio, desprovido de enxofre e resistente à ação da pepsina (enzima que digere proteínas). Chamou esse composto de nucleína.

1889 - Richard Altmann confirmou a natureza ácida desse composto, chamando-o de ácido nucléico.

De 1880 a 1900 - verificou-se que o ácido nucléico continha bases nitrogenadas (adenina, timina, citosina e guanina) e carboidratos (do tipo pentose, com cinco carbonos).

1900 - verificou-se a existência de dois tipos de ácidos nucléicos: um com a base nitrogenada uracila e o carboidrato ribose - ácido ribonucléico (RNA) e outro com a base timina e o carboidrato desoxirribose - ácido desoxirribonucléico (DNA).

1912 - Phoebis Levene e Walter Jacobs concluíram que o componente básico dos ácidos nucléicos era uma estrutura composta por uma base nitrogenada ligada a uma pentose que, por sua vez, estava unida ao fosfato. Essa unidade foi denominada nucleotídeo. Um ácido nucléico seria uma molécula formada por uma série de nucleotídeos ligados entre si (ainda não se sabia como).

\section{Experimentos que relacionam o DNA como sendo o material genético}

* Nesta época, as proteínas eram as melhores candidatas para conterem as informações genéticas, por sua impressionante variabilidade de composição, estrutura e função.

\section{A identificação do material hereditário em bactérias}

Bactérias que causam pneumonia (Streptococcus pneumoniae).

Linhagens $\mathbf{S}$ : produzem uma cápsula de carboidratos e causam a pneumonia em camundongos. Linhagens R: não produzem cápsulas de carboidratos e não causam pneumonia em camundongos. 
1.a) 1928 - Fred Griffith fez o seguinte experimento:

S vivas - camundongo morre

$R$ vivas - camundongo sobrevive

S mortas pelo calor - camundongo sobrevive

$S$ mortas pelo calor $+R$ vivas - camundongo morre

Conclusões: bactérias $\mathrm{R}$ vivas haviam sido transformadas em $\mathrm{S}$ por algum tipo de substância ("princípio transformante") liberado pelas bactérias $\mathrm{S}$ mortas. Essa transformação de bactérias $\mathrm{R}$ em $\mathrm{S}$ foi chamada de transformação bacteriana.

1.b) 1944 - Oswald Avery verificou que a trransformação bacteriana ocorria também in vitro. Em meios de cultura de bactérias $\mathrm{R}$ misturadas com $\mathrm{S}$ mortas, apareciam bactérias $\mathrm{S}$ vivas.

Um colaborador de Avery verificou que a adição de álcool a um extrato de bactérias $\mathrm{S}$ causava a formação de um precipitado espesso que retinha o princípio transformante.

Em 1944, no laboratório de Avery, isolaram grandes quantidades desse princípio e o trataram com:

Amilase: ele continuava com o princípio transformante;

Proteases: ele continuava com o princípio transformante;

Ribonucleases: ele continuava com o princípio transformante;

Desoxirribonucleases: ele perdia o princípio transformante.

Conclusões: Substância transformante é o DNA;

Se o DNA tem a capacidade de transformar características hereditárias das bactérias, ele deve ser o próprio material genético.

Argumentos contra: a amostra poderia estar contaminada com proteínas e que estas seriam responsáveis pela transformação bacteriana.

Contra-argumento: Em 1952 se conseguiram amostras com apenas 0,02\% de proteínas.

A identificação do material hereditário em vírus bacteriófagos

*A questão que se fazia na época era: o material hereditário são as proteínas ou o DNA?

2.a) 1952 - Alfred Hershey e Martha Chase marcaram o DNA de vírus com fósforo radioativo e a proteínas de vírus com enxofre radioativo. Verificaram que apenas o DNA do vírus penetra na bactéria, produzindo em 30 minutos centenas de outros vírus completos. 
Conclusão: A fonte de informações hereditárias é o DNA, pois a partir dele pode ser formado tanto DNA quanto proteínas virais.

\section{Determinação da estrutura do DNA}

*Que características permitiriam ao DNA ser o banco de memória da informação hereditária?

1949 a 1953 - Erwin Chargaff quantificou as bases nitrogenadas em amostras de DNA de diferentes espécies e de diferentes órgãos de indivíduos da mesma espécie.

Conclusões:

a composição de bases varia de espécie para espécie; a composição de bases é constante dentro da espécie; em qualquer espécie, a porcentagem de bases adenina é igual à de timina e a porcentagem de bases citosina é igual à de guanina.

1951 - Maurice Wilkins e Rosalind Franklin, por difração de raios X, determinaram que o DNA tem estrutura helicoidal.

c) 1953 - James Watson e Francis Crick elaboraram um modelo compatível com os resultados experimentais até a época, levando em conta o tamanho e a configuração espacial dos nucleotídeos e respeitava os dados de Chargaff e de raios $\mathrm{X}$.

A molécula é composta por duas cadeias polinucleotídicas dispostas em hélice ao redor de um eixo imaginário. As duas cadeias mantêm-se unidas por meio de pontes de hidrogênio entre os pares de bases específicos: adenina com timina (duas pontes de hidrogênio) e citosina com guanina (três pontes de hidrogênio).

As duas cadeias são complementares: onde em uma delas existir timina, na outra vai haver adenina e, onde existir guanina, na outra existirá citosina.

As duas cadeias são anti-paralelas, ou seja, cada fita possui orientação oposta.

Além disso, o modelo explica a replicação do DNA.

Esse modelo ficou conhecido como modelo da dupla-hélice. 


\section{Anexo 02 - Questão proposta pela professora e respostas dos alunos (originais e argumentos)}

\begin{tabular}{l}
\hline Questão \\
\hline "Por que as conclusões dos experimentos 1 e 2 (que o DNA é o princípio transformante e que o DNA do vírus penetra na \\
bactéria) permitem afirmar que o DNA é o portador das informações hereditárias?" \\
\hline Aluno 1 \\
\hline "Podemos afirmar que o DNA é o portador das informações hereditárias, porque no primeiro experimento quando foi \\
colocado as bactérias que causava a doença (morta) e as bactérias que não causava a doença (viva) esperava-se que o rato \\
não morresse. Mas as informações hereditárias das bactérias mortas passam para as outras bactérias. Assim, o DNA foi \\
modificado e quando reproduzido, seus filhos terão as novas características da mãe, podendo causar a doença. \\
No segundo experimento, conclui-se que o DNA passa as informações, pois foi encontrado fósforo radioativo dentro da \\
bactéria, sendo que o fósforo havia sido colocado antes no DNA do vírus. O vírus se reproduziu e matou a bactéria. \\
Observa-se que em ambas as situações foi por meio do DNA que houve mudanças e que os descendentes adquirem as novas \\
informações, concluindo que é no DNA que estão presentes as informações hereditárias."
\end{tabular}

\section{Aluno 1}

Argumento 1

\begin{tabular}{|c|c|c|}
\hline $\begin{array}{l}\text { D - [Dado que] no primeiro experimento } \\
\text { quando foi colocado as bactérias que } \\
\text { causava a doença (morta) e as bactérias } \\
\text { que não causava a doença (viva) } \\
\text { esperava-se que o rato não morresse. } \\
\text { Mas as informações hereditárias das } \\
\text { bactérias mortas passam para as outras } \\
\text { bactérias. }\end{array}$ & S & $\begin{array}{l}\text { C - Podemos afirmar que o DNA } \\
\text { é o portador das informações } \\
\text { hereditárias. }\end{array}$ \\
\hline & $\begin{array}{l}\text { J - [porque] o DNA foi } \\
\text { modificado e quando } \\
\text { reproduzido, seus filhos terão a } \\
\text { novas características da mãe, } \\
\text { podendo causar a doença. }\end{array}$ & \\
\hline
\end{tabular}

Argumento 2

$\mathrm{D}-[$ Dado que] foi encontrado fósforo
radioativo dentro da bactéria.

$\mathrm{J}$ - [porque] o fósforo havia sido colocado antes no DNA do vírus. $O$ vírus se reproduziu e matou a bactéria. 
Argumento 3

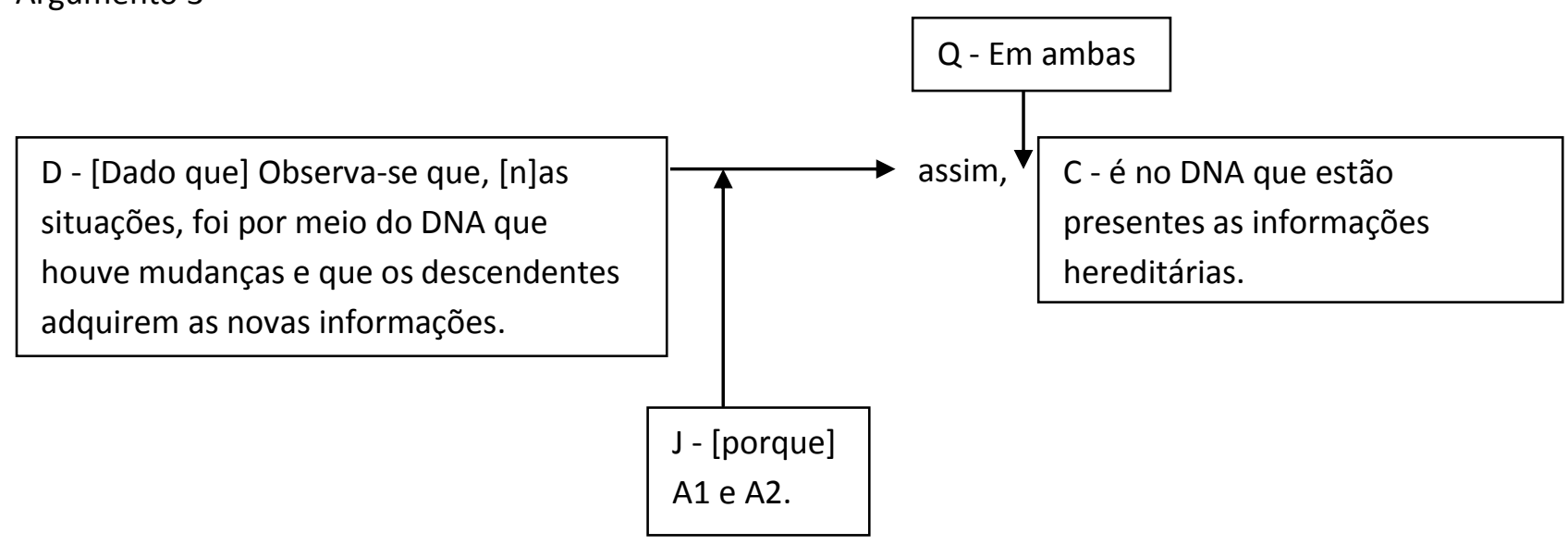

O aluno constrói três argumentos, sendo que os dois primeiros servem de base para a construção do último argumento. $\mathrm{O}$ uso da palavra "ambas" serve não só de indícios de uso dos argumentos anteriores como garantia desse argumento final, mas também como qualificador, dando a força do argumento, pois enumera quando a garantia dada serve de ponte para a passagem dos dados até a conclusão.

Apesar de não apresentarem todos os elementos do formato de argumento proposto, o aluno consegue justificar cientificamente as afirmações feitas a partir de informações extraídas dos experimentos. 


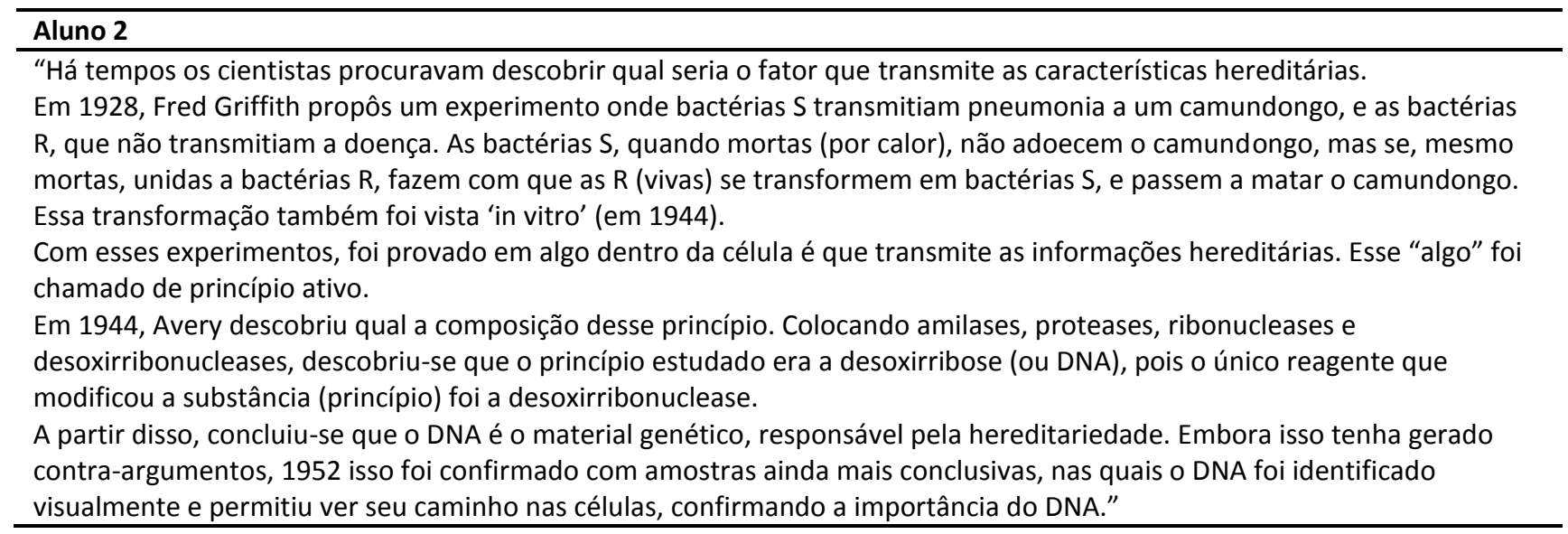

\section{Aluno 2}

Argumento 1

\begin{tabular}{l|l}
$\begin{array}{l}\text { D - [Dado que] Em 1928, Fred Griffith } \\
\text { propôs um experimento onde bactérias S } \\
\text { transmitiam pneumonia a um } \\
\begin{array}{l}\text { camundongo, e as bactérias R, que não } \\
\text { transmitiam a doença. As bactérias S, } \\
\text { quando mortas (por calor), não adoecem }\end{array}\end{array} \quad \begin{array}{l}\text { C - foi provado em algo dentro } \\
\text { da célula é que transmite as }\end{array}$ \\
$\begin{array}{l}\text { informações hereditárias. Esse } \\
\text { "algo" foi chamado de princípio }\end{array}$ \\
ativo.
\end{tabular}
o camundongo, mas se, mesmo mortas, unidas a bactérias $R$, fazem com que as $R$ (vivas) se transformem em bactérias $\mathrm{S}$, e passem a matar o camundongo. Essa transformação também foi vista 'in vitro' (em 1944).

\section{Argumento 2}

D - [Dado que] Em 1944, Avery descobriu qual a composição desse princípio. [e] Colocando amilases, proteases, ribonucleases e desoxirribonucleases. [e] Com esses experimentos.

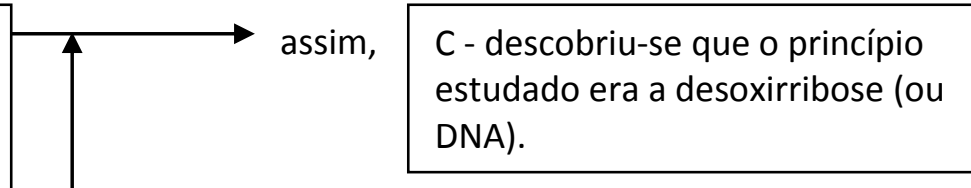
DNA).

Argumento 3

D - [Dado que] A partir disso (A1 e A2). modificou a substância (princípio) foi a desoxirribonuclease. 
nas células, confirmando a importância do DNA." foi excluída por erros conceituais. O experimento citado não permitiu a visualização do caminho do DNA nas células, mas permitiu a identificação de fósforo radioativo dentro da bactéria infectada, o que indica (evidência) que o DNA é responsável pela infecção da bactéria.

O aluno constrói três argumentos, dos quais os dois primeiros são situações particulares que são unidas para a construção do último argumento. Apesar de apresentar uma grande enumeração de fatos para enunciar sua conclusão, nenhuma informação é veiculada no sentido de validar a passagem dos dados à conclusão, portanto, os argumentos 1 e 3 são na forma D logo C. $O$ argumento 2 apresenta garantia explícita para um dos dados enunciados ("foram adicionadas diversas enzimas à solução"). 


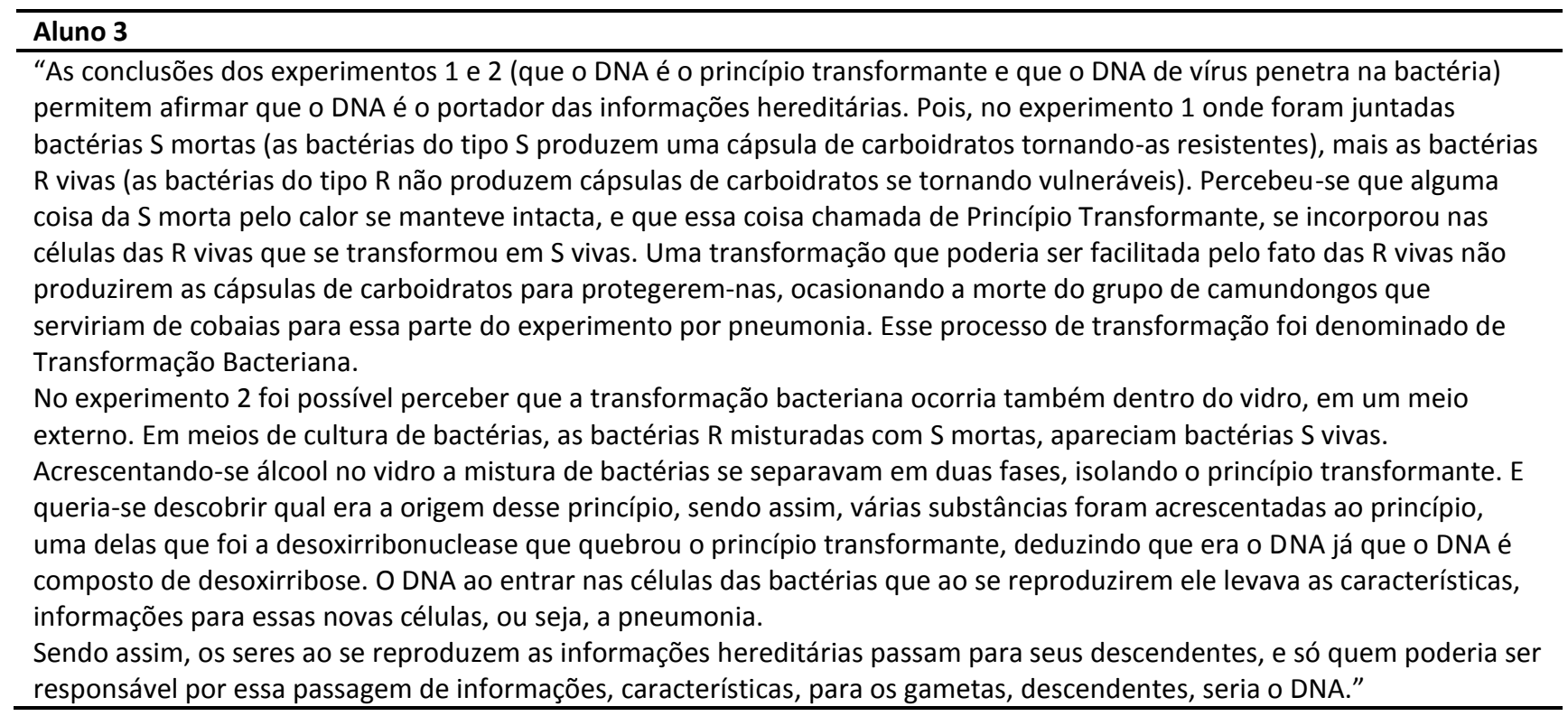

\section{Aluno 3}

\section{Argumento 1}

\begin{tabular}{l|l}
$\begin{array}{l}\text { D - [Dado que] As conclusões dos } \\
\text { experimentos } 1 \text { e } 2 \text { (que o DNA é o } \\
\text { princípio transformante e que o DNA de }\end{array} \quad \longrightarrow$ assim, & $\begin{array}{l}\text { C - permitem afirmar que o DNA } \\
\text { é o portador das informações } \\
\text { hereditárias. }\end{array}$
\end{tabular}

$\mathrm{J}$ - [porque]

(a) Pois, no experimento 1 onde foram juntadas bactérias $\mathrm{S}$ mortas (as bactérias do tipo $S$ produzem uma cápsula de carboidratos tornando-as resistentes), mais as bactérias $R$ vivas (as bactérias do tipo $\mathrm{R}$ não produzem cápsulas de carboidratos se tornando vulneráveis). Percebeu-se que alguma coisa da $\mathrm{S}$ morta pelo calor se manteve intacta, $\mathrm{e}$ que essa coisa chamada de Princípio Transformante, se incorporou nas células das $R$ vivas que se transformou em $S$ vivas. Uma transformação que poderia ser facilitada pelo fato das $R$ vivas não produzirem as cápsulas de carboidratos para protegerem-nas, ocasionando a morte do grupo de camundongos que serviriam de cobaias para essa parte do experimento por pneumonia. Esse processo de transformação foi denominado de Transformação Bacteriana.

(b) No experimento 2 foi possível perceber que a transformação bacteriana ocorria também dentro do vidro, em um meio externo. Em meios de cultura de bactérias, as bactérias $\mathrm{R}$ misturadas com $\mathrm{S}$ mortas, apareciam bactérias $\mathrm{S}$ vivas. Acrescentando-se álcool no vidro a mistura de bactérias se separavam em duas fases, isolando o princípio transformante. E queria-se descobrir qual era a origem desse princípio, sendo assim, várias substâncias foram acrescentadas ao princípio, uma delas que foi a desoxirribonuclease que quebrou o princípio transformante, deduzindo que era o DNA já que o DNA é composto de desoxirribose. O DNA ao entrar nas células das bactérias que ao se reproduzirem ele levava as características, informações para essas novas células, ou seja, a pneumonia. 
Argumento 2

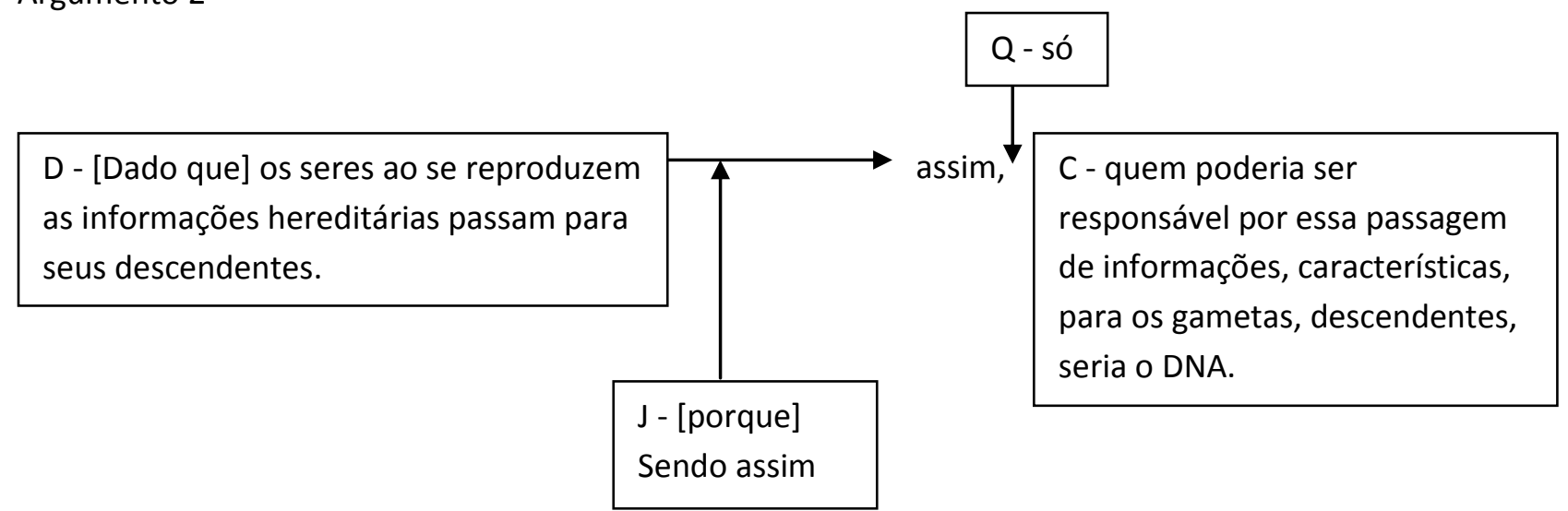

São construídos 2 argumentos, sendo que o primeiro apresenta dado, garantia, apoio para a garantia e conclusão. A garantia apresentada é narrativa e engloba os dois experimentos citados em aula. É coerente com o dado proposto, pois neste são citados os dois experimentos como responsáveis pela conclusão (DNA é portador das informações hereditárias).

O segundo argumento não apresenta apoio, porém apresenta qualificador, dando força para a afirmação dada. Além disso, indica ("sendo assim") o uso do argumento 1 como garantia para a afirmação construída. 


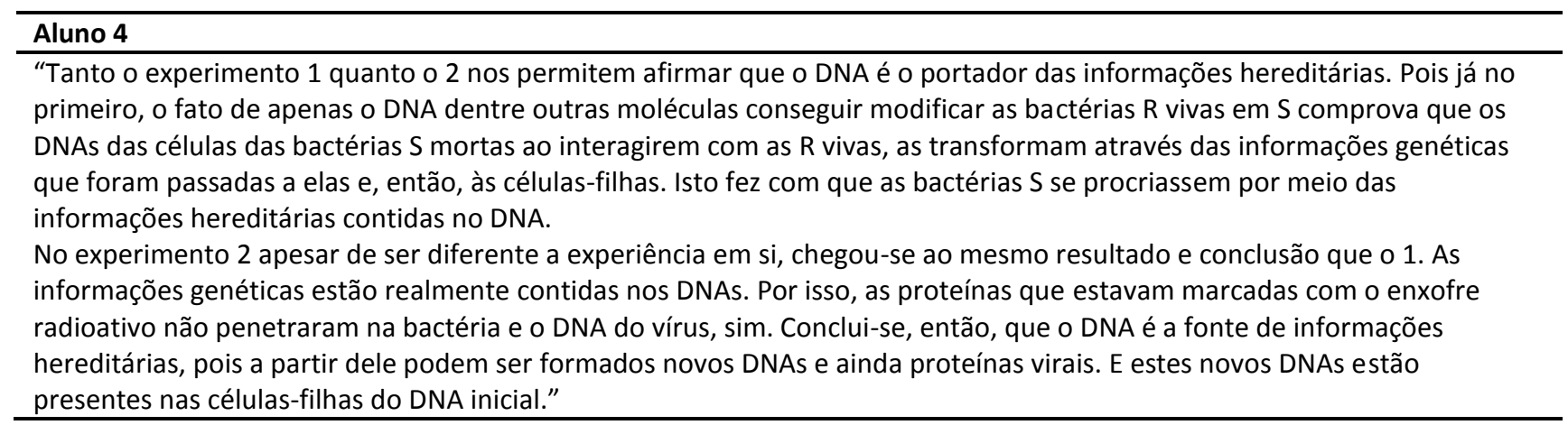

\section{Aluno 4}

Argumento 1

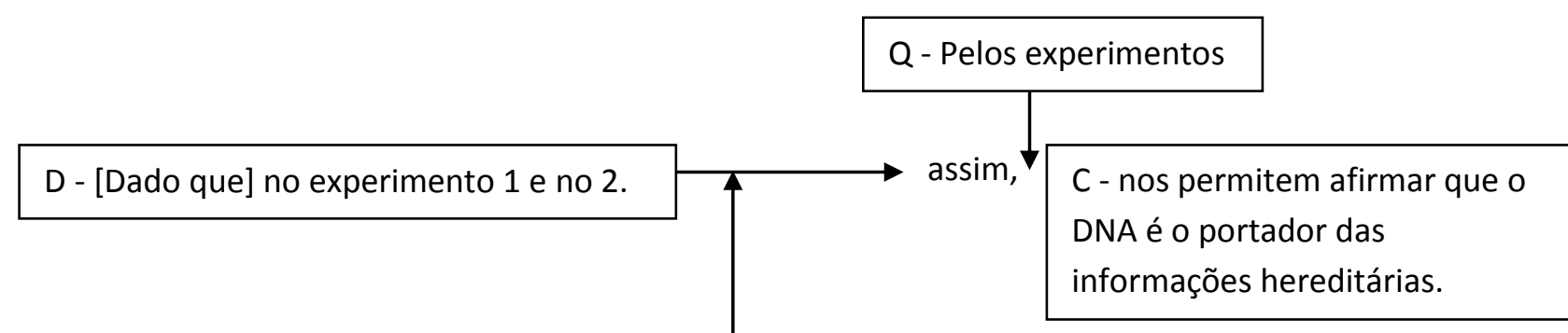

J - [porque] já no primeiro [experimento], o fato de apenas o DNA dentre outras moléculas conseguir modificar as bactérias $R$ vivas em $S$ comprova que os DNAs das células das bactérias $S$ mortas ao interagirem com as $R$ vivas, as transformam através das informações genéticas que foram passadas a elas e, então, às células-filhas. Isto fez com que as bactérias $\mathrm{S}$ se procriassem por meio das informações hereditárias contidas no DNA.

O qualificador foi modificado para que fizesse sentido na forma de argumento. $O$ aluno expressa o qualificador pelas conjunções "tanto quanto", dando a entender que o experimento 1 ou o experimento 2 poderiam ser suficientes para embasar a conclusão geral. A justificativa formulada não está completa, pois indica apenas porque aceitar o primeiro experimento como dado para a conclusão, porém não embasa a afirmação de que o segundo experimento também seria responsável pela mesma conclusão. Sendo assim, consideramos o argumento fraco.

Argumento 2

D - [Dado que] As informações genéticas
estão realmente contidas nos DNAs, com
esses experimentos.

C - as proteínas que estavam marcadas com o enxofre radioativo não penetraram na bactéria e o DNA do vírus, sim. 
D - [Dado que] a partir dele [DNA] podem ser formados novos DNAs e ainda proteínas virais. E estes novos DNAs estão presentes nas células-filhas do DNA inicial.
C - Conclui-se, então, que o DNA é a fonte de informações hereditárias.

O aluno constrói três argumentos, sendo que dois deles (1ำ e 3으) enunciam a mesma conclusão a partir de dados diferentes. O primeiro argumento é uma paráfrase do enunciado da questão, enquanto o último argumento traz um resultado de experimento como dado, indicando que o aluno foi capaz de articular os conceitos na construção de sua resposta.

No segundo argumento formulado, o aluno inverte a ordem cronológica dos fatos, indicando que o enxofre radioativo não penetra na bactéria, pois as informações genéticas estão no DNA. Historicamente a conclusão foi o inverso da enunciada, pois foi a partir das evidências experimentais de que a cápsula marcada com enxofre radioativo não penetrava na bactéria que os cientistas extrapolaram dizendo que o DNA (marcado com fósforo radioativo) era responsável pela replicação do vírus no interior da bactéria. 0 argumento 2, portanto, é falacioso. 


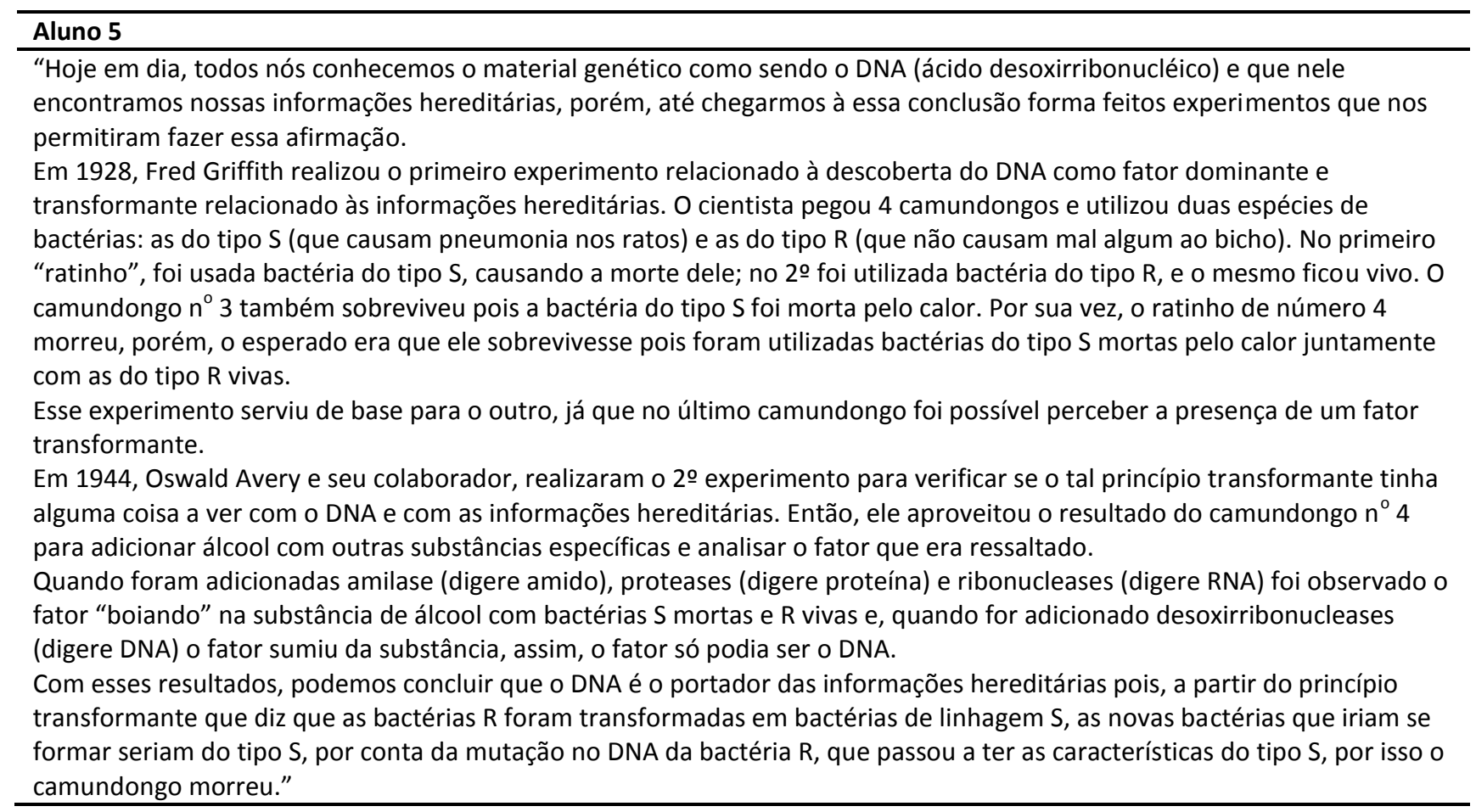

\section{Argumento 1}
D - [Dado que] no último camundongo foi possível perceber a presença de um fator transformante.

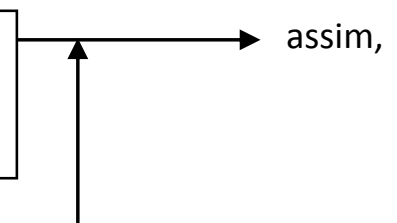
C - Esse experimento serviu de base para o outro.


Argumento 2

D - [Dado que] Em 1944, Oswald Avery e

seu colaborador, realizaram o 20

experimento para verificar se o tal

princípio transformante tinha alguma coisa

a ver com o DNA e com as informações

hereditárias. Então, ele aproveitou o

resultado do camundongo $n^{\circ} 4$ para

adicionar álcool com outras substâncias

específicas e analisar o fator que era

ressaltado. Quando foram adicionadas

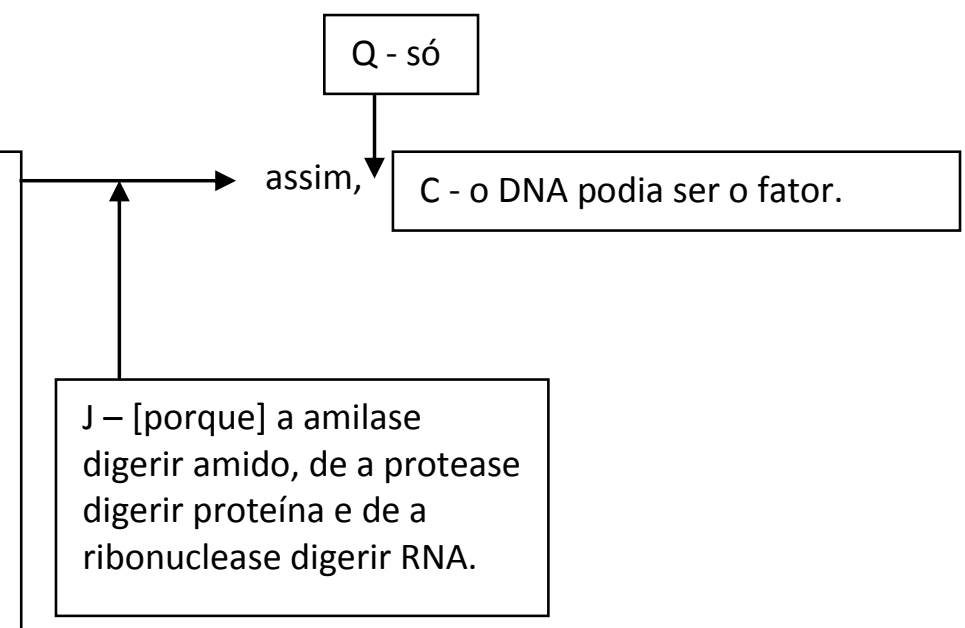

amilase (...), proteases (...) e ribonucleases

(...) foi observado o fator "boiando" na

substância de álcool com bactérias $S$

mortas e R vivas e, quando for adicionado

desoxirribonucleases (digere DNA) o fator

sumiu da substância.

Trechos a justificativa e da conclusão foram parafraseados para que fizessem sentido na forma de argumento.

Argumento 3

D - [Dado que] Com esses resultados (A1 e A2).

assim,

C - podemos concluir que o DNA

é o portador das informações.

$\mathrm{J}$ - [porque] a partir do princípio transformante que diz que as bactérias $\mathrm{R}$ foram transformadas em bactérias de linhagem $\mathrm{S}$, as novas bactérias que iriam se formar seriam do tipo $S$, por conta da mutação no DNA da bactéria $R$, que passou a ter as características do tipo $S$, por isso o camundongo morreu.

A J3 é fraca, pois não permite passar de D3 a C3, uma vez que ela cita dois experimentos no dado e só explica um deles na garantia.

O aluno apresenta três argumentos. No terceiro argumento formulado, utiliza os argumentos anteriores como dado e apresenta uma garantia semelhante à garantia apresentada no primeiro argumento. No primeiro argumento essa garantia é a ponte que permite a passagem do dado à conclusão, porém, no argumento 3, a garantia é falha, pois o dado apresenta os dois experimentos como fatos que permitem a enunciação da conclusão.

O primeiro argumento é interessante também, pois o aluno é capaz de veicular o resultado relevante do experimento que leva à conclusão e justificar cientificamente por que podemos passar do dado à conclusão.

O segundo argumento formulado a partir da resposta do aluno não apresenta o resultado do experimento como dado, mas sim toda a narrativa de como ocorreu o experimento, embasada no conceito científico. A partir do conceito veiculado na justificativa é possível aceitar a afirmação enunciada na conclusão. 


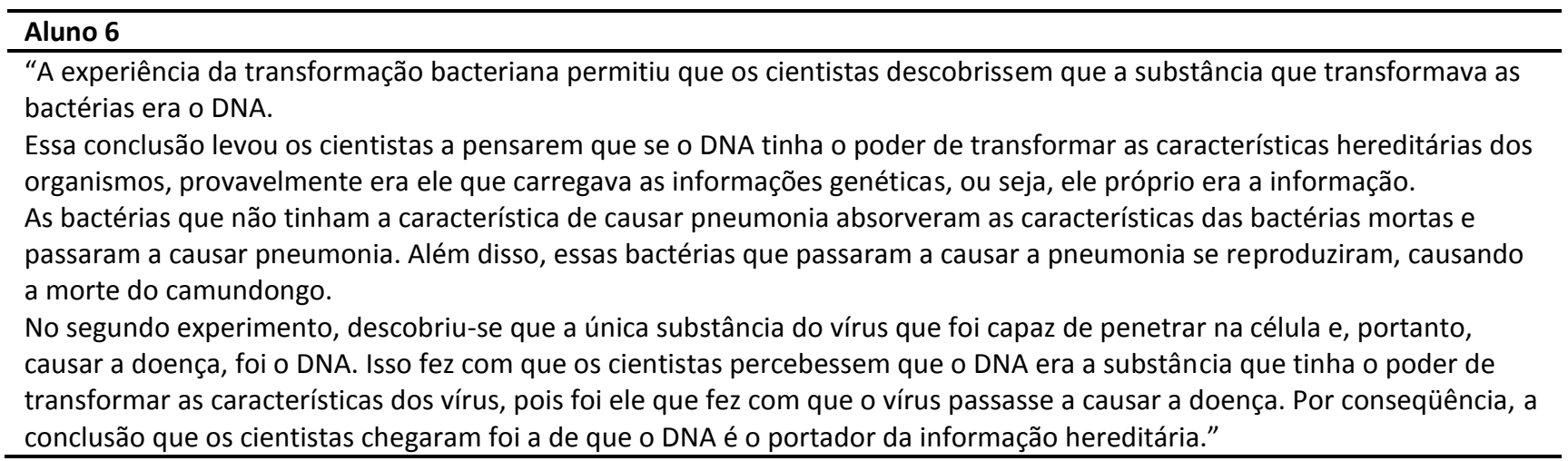

\section{Aluno 6}

Argumento 1

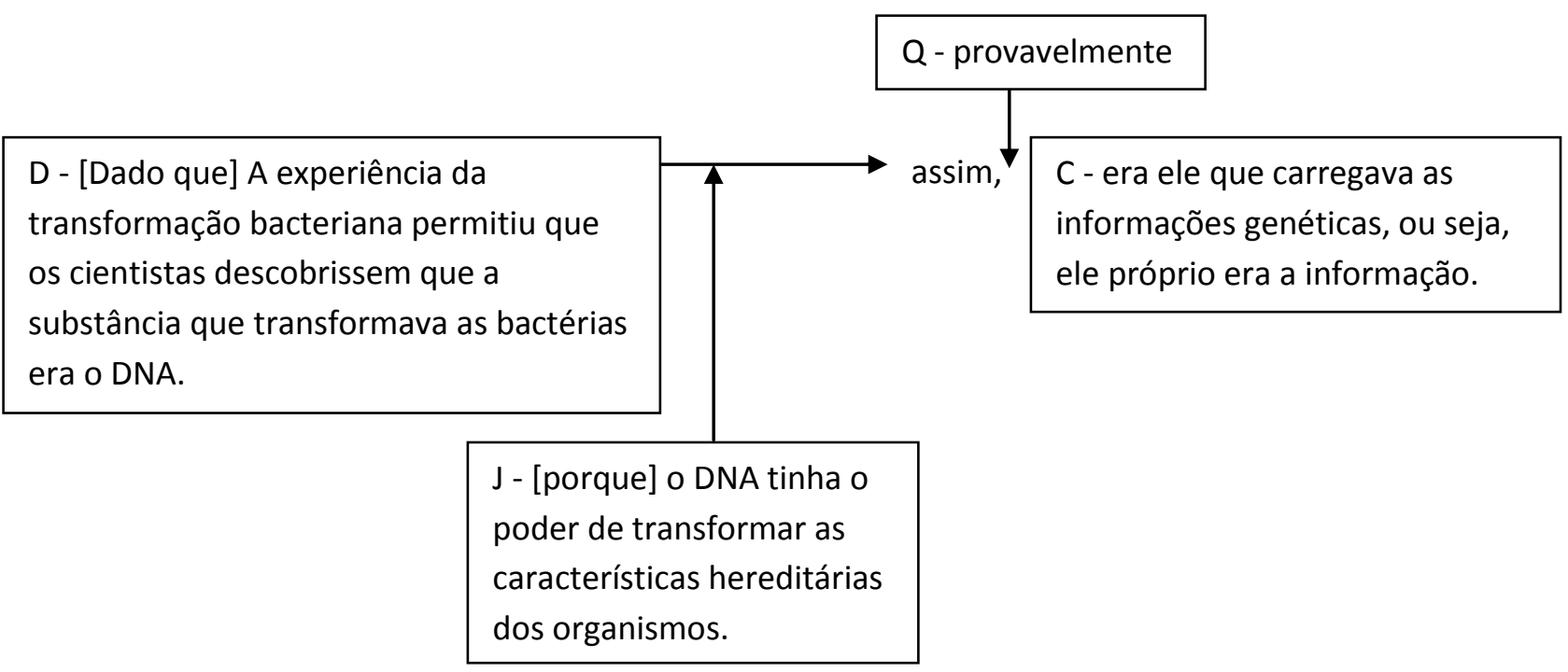

O trecho "As bactérias que não tinham a característica de causar pneumonia absorveram as características das bactérias mortas e passaram a causar pneumonia. Além disso, essas bactérias que passaram a causar a pneumonia se reproduziram, causando a morte do camundongo." Foi desconsiderado por erros conceituais.

O trecho "No segundo experimento, descobriu-se que a única substância do vírus que foi capaz de penetrar na célula e, portanto, causar a doença, foi o DNA. Isso fez com que os cientistas percebessem que o DNA era a substância que tinha o poder de transformar as características dos vírus, pois foi ele que fez com que o vírus passasse a causar a doença. Por consequência, a conclusão que os cientistas chegaram foi a de que o DNA é o portador da informação hereditária." Foi desconsiderado por erros conceituais.

O trecho "se o DNA tinha o poder de transformar as características hereditárias dos organismos" apresenta erros conceituais, porém podemos relevá-lo para que seja possível visualizar o argumento construído a partir da escrita do aluno. 


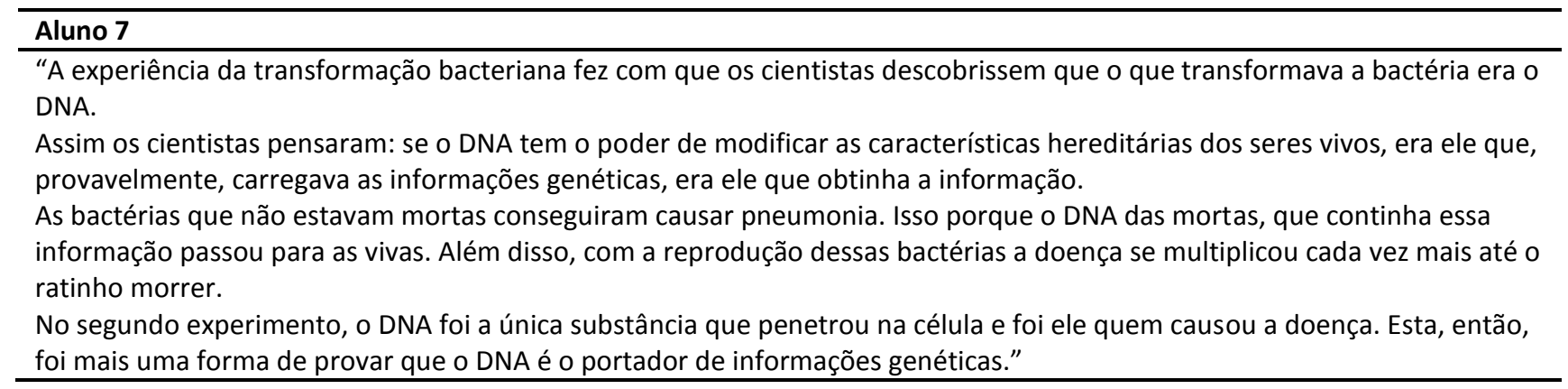

\section{Aluno 7}

Argumento 1

\begin{tabular}{|l|l|l|}
\hline $\begin{array}{l}\text { D - [Dado que] A experiência da } \\
\text { transformação bacteriana fez com que os } \\
\text { cientistas descobrissem que o que } \\
\text { transformava a bactéria era o DNA. }\end{array}$ & $\begin{array}{l}\text { Q assim, - provavelmente } \\
\text { as informações genéticas, era } \\
\text { ele [DNA] que obtinha a } \\
\text { informação. }\end{array}$ \\
\hline
\end{tabular}

J - [porque] As bactérias que não
estavam mortas conseguiram causar
pneumonia. Isso porque o DNA das
mortas, que continha essa informação
passou para as vivas. Além disso, com
a reprodução dessas bactérias a
doença se multiplicou cada vez mais
até o ratinho morrer.

Argumento 2

D - [Dado que] No segundo experimento, o DNA foi a única substância que penetrou na célula e foi ele quem causou a doença.
C - que o DNA é o portador de informações genéticas.

São formulados dois argumentos de igual conclusão, porém em cada um deles o aluno se utiliza dos resultados dos dois experimentos realizados para chegar à conclusão. $O$ aluno se utiliza de qualificadores que dão força ao argumento formulado. No primeiro, a palavra provavelmente indica a conclusão parcial e ainda incerta dos cientistas da época sobre a função do DNA. Já o qualificador apresentado para o segundo argumento tenta dar força ao argumento, mas não é apresentada nenhuma justificativa, ou seja, nenhuma informação que nos permita entender como ele passa do dado à conclusão.

Existe uma grande semelhança com o aluno 6. Pensamos que esses alunos podem ter feito o exercício em um mesmo grupo ou apenas que um aluno copiou do outro, parafraseando a resposta do outro. 


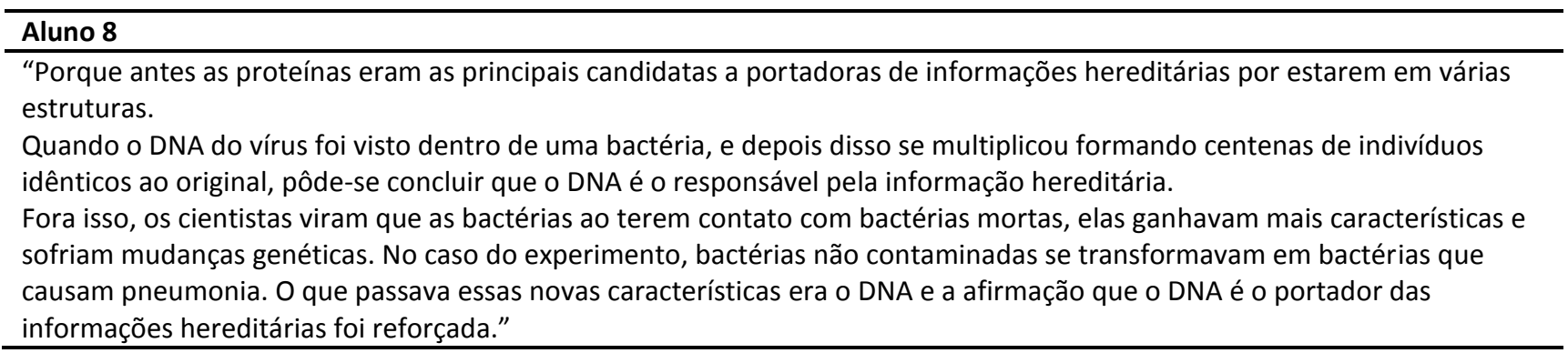

\section{Aluno 8}

Argumento 1

D - [Dado que] por estarem em várias estruturas.

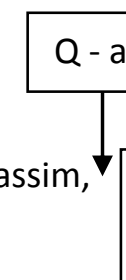

C - as proteínas eram as principais candidatas a portadoras de informações hereditárias.

Argumento 2

D - [Dado que] Quando o DNA do vírus foi visto dentro de uma bactéria, e depois disso se multiplicou formando centenas de indivíduos idênticos ao original.
C - pôde-se concluir que o DNA é o responsável pela informação hereditária.

\section{Argumento 3}

\section{D - [Dado que] Fora isso, os cientistas} viram que as bactérias ao terem contato com bactérias mortas, elas ganhavam mais características e sofriam mudanças genéticas. No caso do experimento, bactérias não contaminadas se transformavam em bactérias que causam pneumonia. O que passava essas novas características era o DNA. assim,
C - a afirmação que o DNA é o portador das informações hereditárias foi reforçada.

O aluno constrói três argumentos sem justificativa que valide a passagem dos dados às conclusões. O primeiro argumento apresenta um qualificador, que delimita a validade da afirmação temporalmente e os outros dois argumentos descrevem os dois experimentos citados em aula e enunciam uma mesma conclusão. A resposta, portanto, é considerada fraca. 


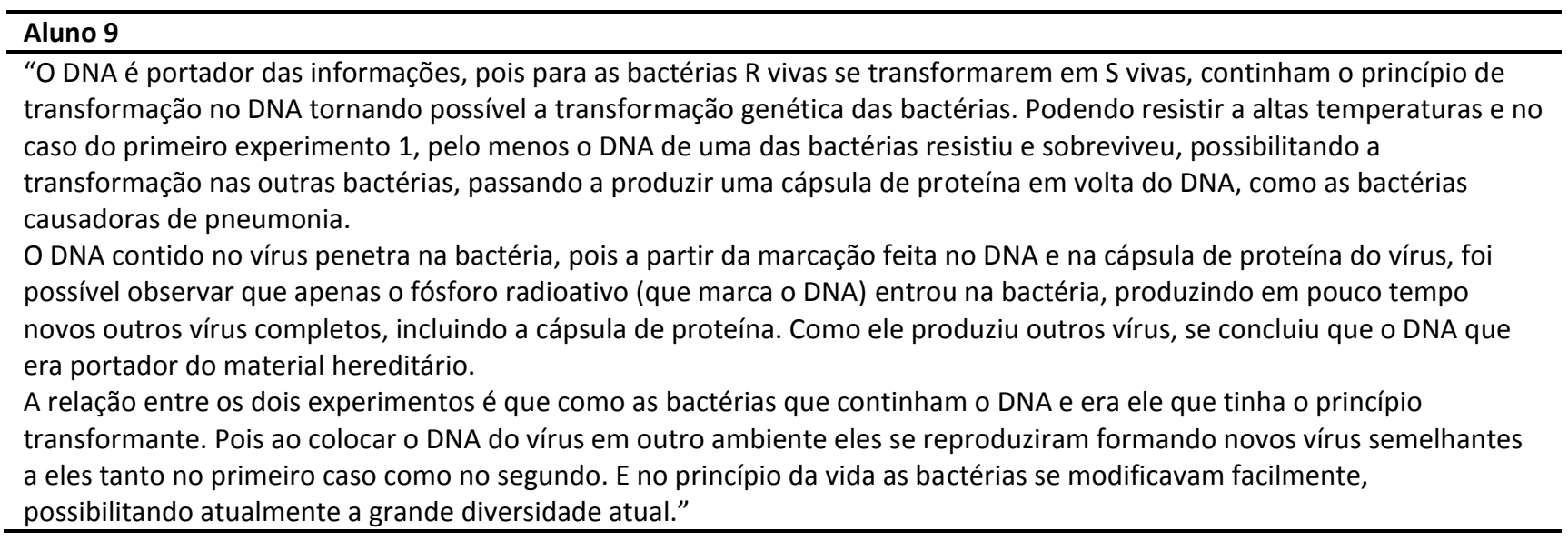

\section{Aluno 9}

Argumento 1

\begin{tabular}{|l|l|}
\hline $\begin{array}{l}\text { D - [Dado que] pois para as bactérias } \mathrm{R} \\
\text { vivas se transformarem em S vivas, } \\
\text { continham o princípio de transformação }\end{array}$ & $\longrightarrow$ assim, $\begin{array}{l}\text { C - Tornou-se possível a } \\
\text { transformação genética das } \\
\text { bactérias. }\end{array}$ \\
\hline
\end{tabular}
no DNA.

Na formulação do argumento nós modificamos o termo no gerúndio (de "tornando" para "tornou$\left.\mathrm{se}^{\prime \prime}\right)$ para que fizesse sentido na forma de argumento.

\section{Argumento 2}

D - [Dado que] para as bactérias $R$ vivas se transformarem em $S$ vivas, continham o princípio de transformação no DNA tornando possível a transformação genética das bactérias. assim,

\section{C - O DNA é portador das} informações.

$$
\begin{aligned}
& \text { J - [porque] no caso do primeiro } \\
& \text { experimento 1, pelo menos o DNA de } \\
& \text { uma das bactérias resistiu e sobreviveu, } \\
& \text { possibilitando a transformação nas } \\
& \text { outras bactérias, passando a produzir } \\
& \text { uma cápsula de proteína em volta do } \\
& \text { DNA, como as bactérias causadoras de } \\
& \text { pneumonia. }
\end{aligned}
$$

"Podendo resistir a altas temperaturas" foi desconsiderado, pois é um trecho sem conexão clara com nenhuma parte do parágrafo. 
Argumento 3

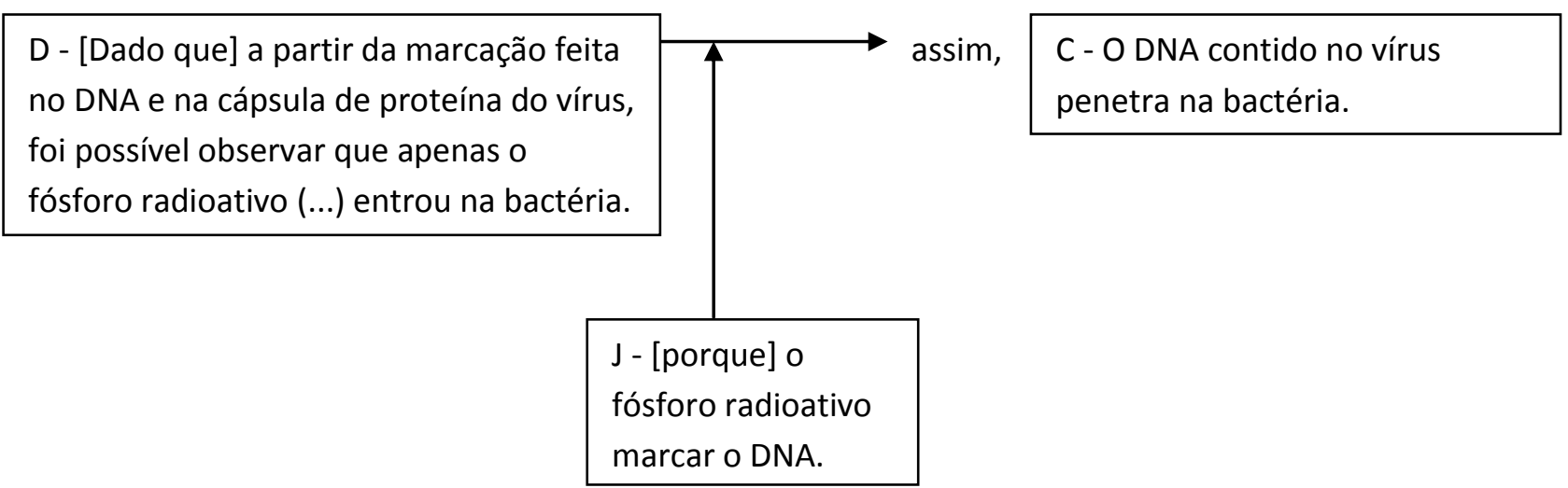

Justificativa parafraseada para fazer sentido na forma de argumento.

Argumento 4

D - [Dado que] (A3) + produzindo em
pouco tempo novos outros vírus
completos, incluindo a cápsula de
proteína. Como ele produziu outros vírus.

C - se concluiu que o DNA que

era portador do material.

O trecho: "A relação entre os dois experimentos é que como as bactérias que continham o DNA e era ele que tinha o princípio transformante. Pois ao colocar o DNA do vírus em outro ambiente eles se reproduziram formando novos vírus semelhantes a eles tanto no primeiro caso como no segundo. E no princípio da vida as bactérias se modificavam facilmente, possibilitando atualmente a grande diversidade atual." foi desconsiderado por erros conceituais.

O aluno constrói quatro argumentos, sendo que o primeiro deles é tautológico, pois o dado e a conclusão apresentam a mesma informação. Dos três argumentos subsequentes, os argumentos 2 e 4 apresentam a mesma conclusão a partir de dados e justificativas diferentes. 0 argumento 2 apresenta uma extrapolação a partir dos resultados dos experimentos, enquanto 0 argumento 3 apresenta 0 conhecimento básico de que fósforo radioativo marca a molécula de DNA.

O argumento 3 é um trecho do argumento 4, afirmação estabelecida tal qual a afirmação do experimento (a partir da evidência do fósforo radioativo dentro da célula, os cientistas concluem que o DNA do vírus é a parte que entra na bactéria). Uma vez estabelecido tal resultado, o aluno pode continuar e explicar sobre a replicação viral e a morte da bactéria, que serve de fato (evidência) para a conclusão enunciada. Porém, o argumento 4 é considerado fraco, pois não apresenta uma justificativa que nos permita aceitar a relação entre o dado e a conclusão. 


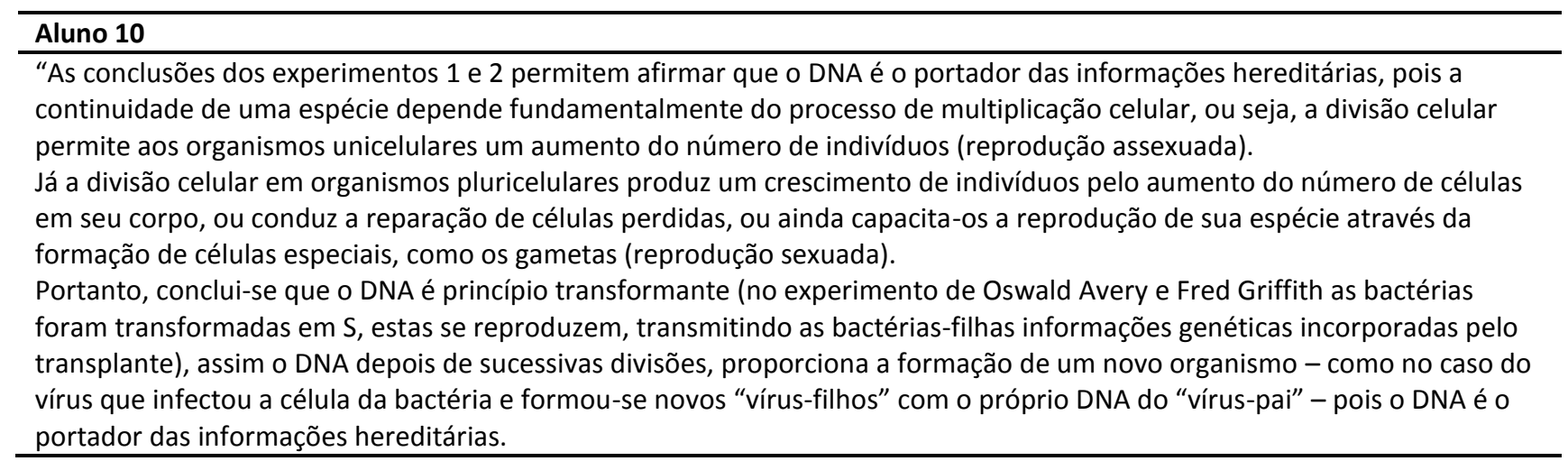

\section{Aluno 10}

Argumento 1

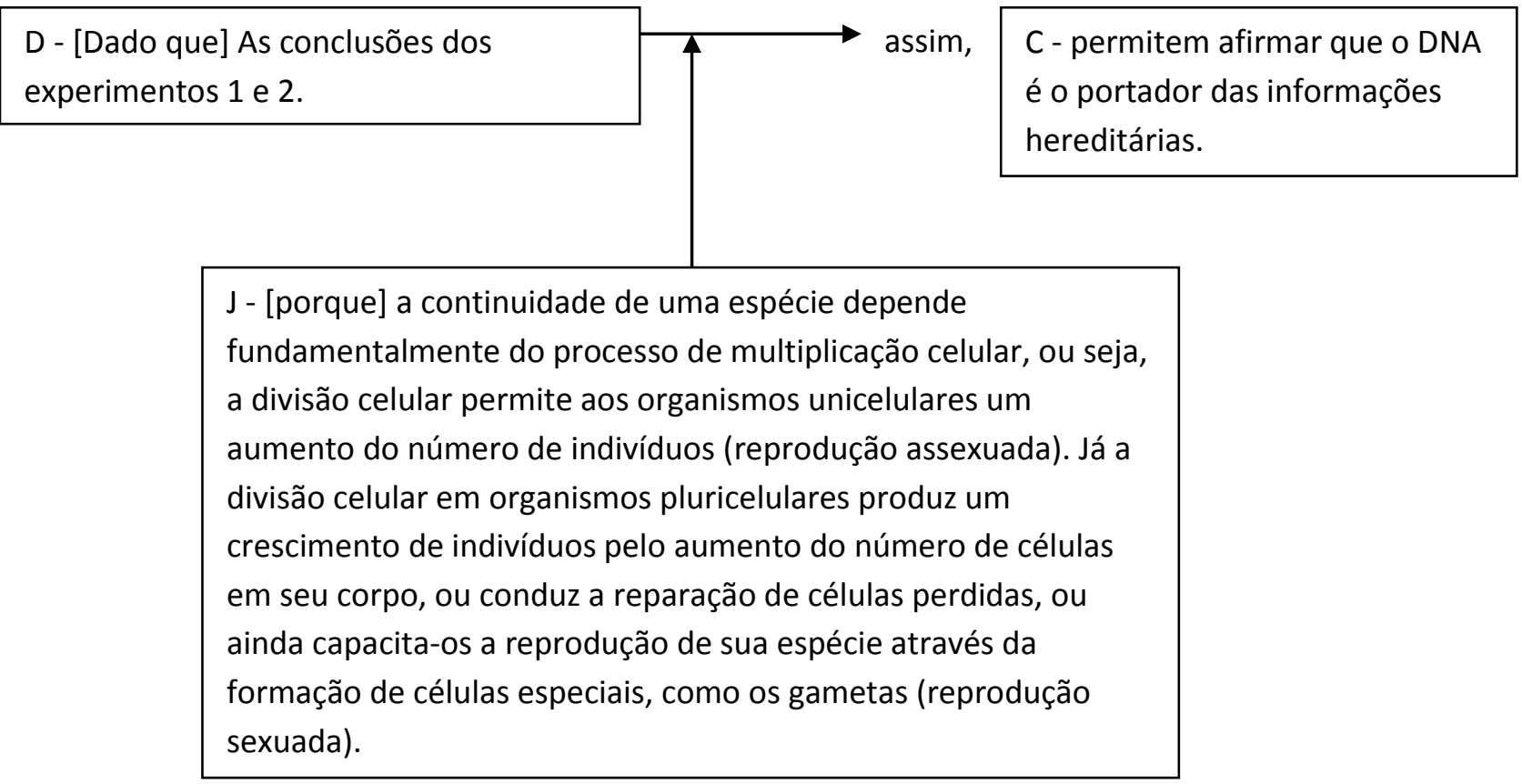

Essa justificativa não permite a passagem do dado e conclusão apresentados

"Portanto, conclui-se que o DNA é princípio transformante (no experimento de Oswald Avery e Fred Griffith as bactérias foram transformadas em $S$, estas se reproduzem, transmitindo as bactérias-filhas informações genéticas incorporadas pelo transplante), assim o DNA depois de sucessivas divisões, proporciona a formação de um novo organismo - como no caso do vírus que infectou a célula da bactéria e formou-se novos "vírus-filhos" com o próprio DNA do "vírus-pai" - pois o DNA é o portador das informações hereditárias."

Não é estabelecida alguma relação entre dado e conclusão. Algumas informações são conceitualmente erradas. 


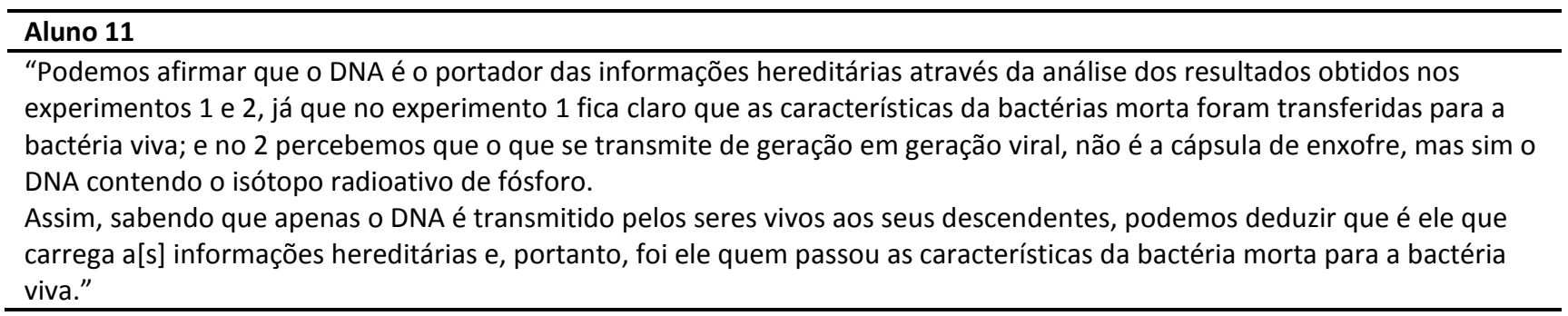

\section{Aluno 11}

Argumento 1

\begin{tabular}{l}
$\begin{array}{l}\text { D - [Dado que] através da análise dos } \\
\text { resultados obtidos nos experimentos 1 e } \\
2 .\end{array}$ \\
\cline { 2 - 2 }
\end{tabular}
$\mathrm{J}$ - [porque] no experimento 1 fica claro que as características da bactérias morta[s] foram transferidas para a bactéria viva; e no 2 percebemos que o que se transmite de geração em geração viral, não é a cápsula de enxofre, mas sim o DNA contendo o isótopo radioativo de fósforo.

Argumento 2

$\begin{aligned} & \text { D - [Dado que] sabendo que apenas o } \\ & \text { DNA é transmitido pelos seres vivos aos } \\ & \text { seus descendentes. }\end{aligned}$
nassim, $\begin{aligned} & \text { C - podemos deduzir que é ele } \\ & \text { [DNA] que carrega a[s] } \\ & \text { informações hereditárias. }\end{aligned}$

"e, portanto, foi ele quem passou as características da bactéria morta para a bactéria viva." Afirmação à parte, sem defesa, ou seja, sem dado ou justificativa que a possibilite. Há o conectivo "portanto" que enuncia uma relação de conclusão, não de justificativa. 


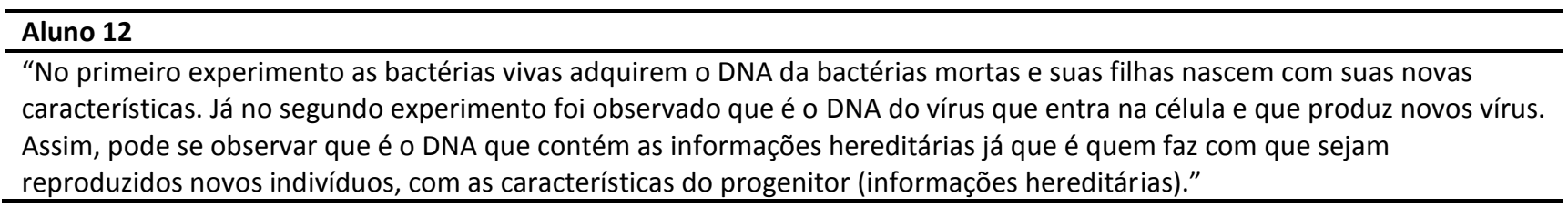

\section{Aluno 12}

\section{Argumento 1}

D - [Dado que] No primeiro experimento as bactérias vivas adquirem o DNA da bactérias mortas e suas filhas nascem com suas novas características. Já no segundo experimento foi observado que é o DNA do vírus que entra na célula e que produz novos vírus.

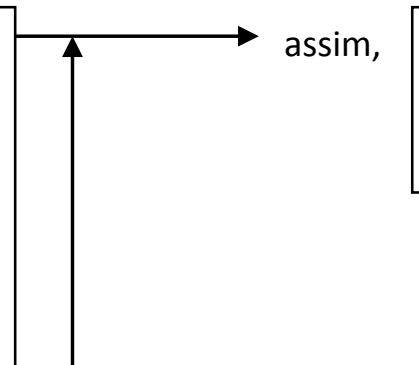

C - Assim, pode se observar que é o DNA que contém as informações hereditárias.

J - [porque] [o DNA] é quem faz com que

sejam reproduzidos novos indivíduos, com as características do progenitor

(informações hereditárias).

O aluno constrói um argumento com justificativa para defender a conclusão esperada ("o DNA que contém as informações hereditárias"). A justificativa é conceitual e está correta, mas não diz respeito aos experimentos explicados durante a aula. 


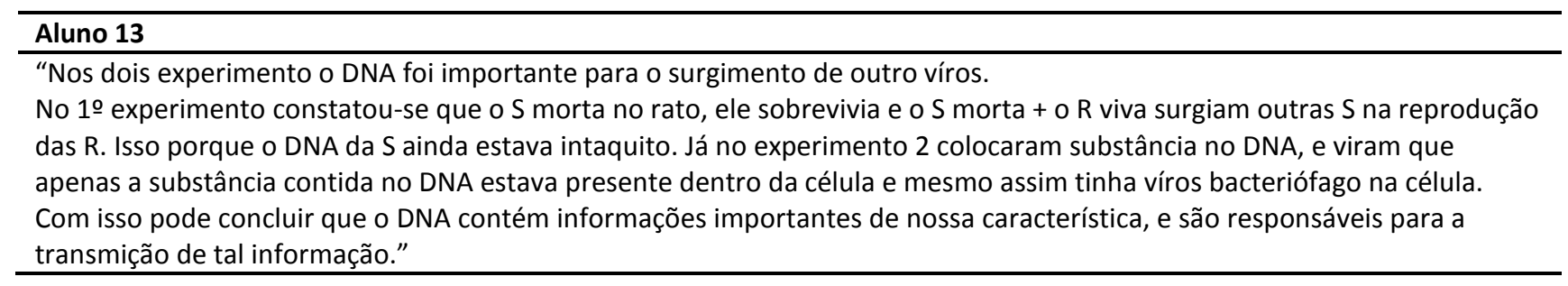

\section{Aluno 13}

Argumento 1

D - [Dado que] No 10 experimento constatou-se que [a] S morta no rato, ele sobrevivia e [a] S morta + [a] R viva surgiam outras $S$ na reprodução das $R$.

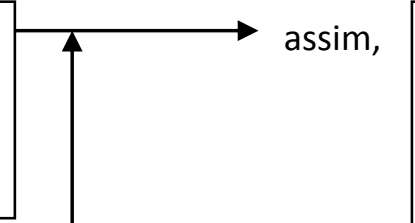

C - Com isso pode concluir que o DNA contém informações importantes de nossa característica, e são responsáveis para a transmissão de tal informação.

$$
\begin{aligned}
& \text { J - [porque] Isso porque } \\
& \text { o DNA da S ainda estava } \\
& \text { intacto. }
\end{aligned}
$$

"Nos dois experimento o DNA foi importante para o surgimento de outro vírus." Trecho descartado por erro conceitual

"Já no experimento 2 colocaram substância no DNA, e viram que apenas a substância contida no DNA estava presente dentro da célula e mesmo assim tinha vírus bacteriófago na célula." O trecho tem potencial para apresentar outro dado e outra justificativa para a mesma conclusão, mas não há conectivo que estabeleça tais relações na frase. 


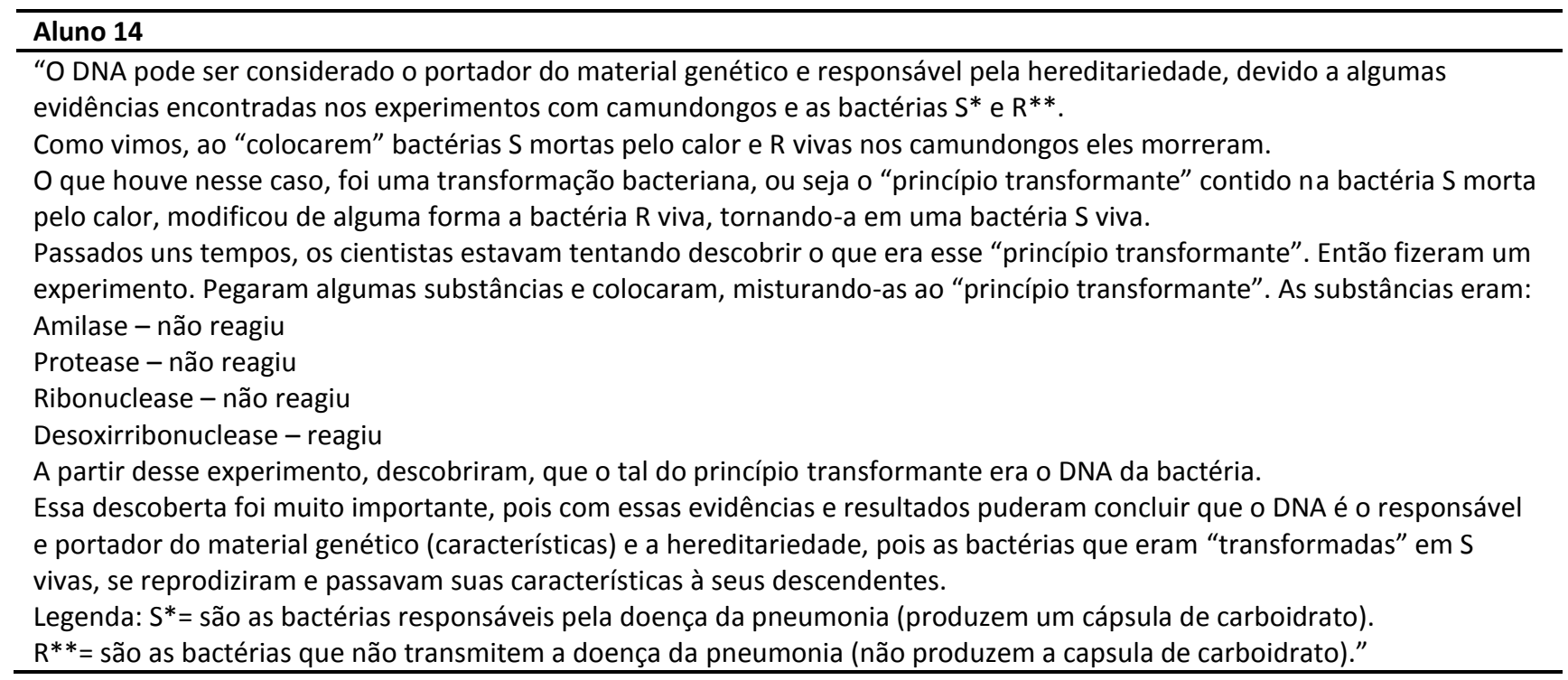

\section{Aluno 14}

\section{Argumento 1}

D - [Dado que] algumas evidências
encontradas nos experimentos com
camundongos e as bactérias $\mathrm{S}^{*}$ e $\mathrm{R}^{* *}$.
Legenda: $\mathrm{S}^{*}=$ são as bactérias
responsáveis pela doença da pneumonia
(produzem um cápsula de carboidrato).
$\mathrm{R}^{* *}=$ são as bactérias que não
transmitem a doença da pneumonia (não
produzem a cápsula de carboidrato).

J - [porque] A2. 
Argumento 2

D - [Dado que] (a) Como vimos, ao "colocarem" bactérias S mortas pelo calor e $\mathrm{R}$ vivas nos camundongos eles morreram.

(b) Passados uns tempos, os cientistas estavam tentando descobrir o que era esse "princípio transformante". Então fizeram um experimento. Pegaram algumas substâncias e colocaram, misturando-as ao "princípio transformante". As substâncias eram: Amilase - não reagiu

Protease - não reagiu

Ribonuclease - não reagiu

Desoxirribonuclease - reagiu

$$
\begin{aligned}
& \text { J - [porque] (a) O que houve nesse caso, } \\
& \text { foi uma transformação bacteriana, ou seja } \\
& \text { o "princípio transformante" contido na } \\
& \text { bactéria S morta pelo calor, modificou de } \\
& \text { alguma forma a bactéria R viva, tornando- } \\
& \text { a em uma bactéria S viva. }
\end{aligned}
$$

O trecho (b) dos dados poderia ser colocado como justificativa caso o aluno tivesse criado uma relação, porém não há articulação dos resultados do experimento como justificativa. Além disso, não é explicado, uma vez no papel de dado, qual é a justificativa para o trecho (b).

"Essa descoberta foi muito importante, pois com essas evidências e resultados puderam concluir que o DNA é o responsável e portador do material genético (características) e a hereditariedade, pois as bactérias que eram "transformadas" em S vivas, se reproduziam e passavam suas características à seus descendentes." Trecho descartado as informações, apesar de corretas, estão truncadas e cabe ao leitor reorganizá-las para que façam sentido. 


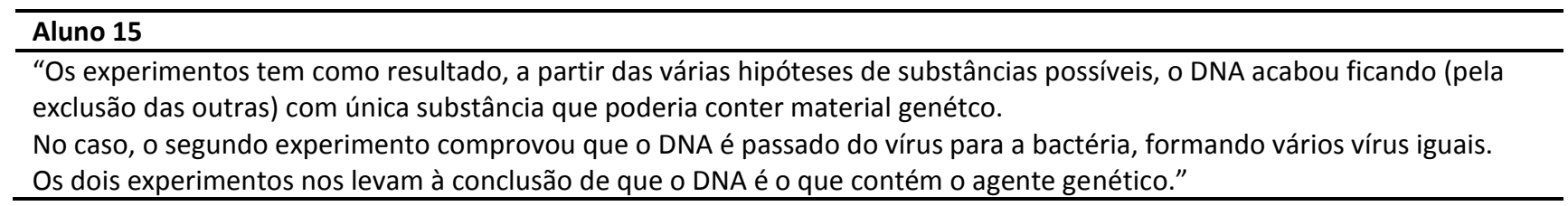

\section{Aluno 15}

Argumento 1
D - [Dado que] a partir das várias
hipóteses de substâncias possíveis.
assim,
C - o DNA acabou ficando com
única substância que poderia
conter material genético.

$\mathrm{J}$ - [porque] (pela

exclusão das outras).

Argumento 2

D - [Dado que] o segundo experimento. assim,
C - comprovou que o DNA é passado do vírus para a bactéria, formando vários vírus iguais.

Argumento 3

D - [Dado que] Os dois experimentos. $\longrightarrow$ assim,

nos levam à conclusão de que o

DNA é o que contém o agente genético.

$\mathrm{O}$ aluno escreve 3 argumentos, sendo que apenas um deles tem justificativa. $\mathrm{O}$ primeiro e o segundo argumentos são pontuais, enquanto o terceiro argumento é geral, mas não fica claro no texto os dois argumentos anteriores serviriam de justificativa para esse argumento, apesar de dar essa impressão.

\footnotetext{
Aluno 16

"Em ambos os experimentos o resultado sucedido foi de igual conclusão. Tanto no primeiro quanto no segundo, várias possíveis substâncias foram testadas com o fim de se chegar à responsável pela informação genética.

Em todos os casos, os cientistas chegaram ao mesmo resultado, o DNA era o único que podia ser responsável pelo material genético.

E então visto que o DNA dos vírus era resultante da informação hereditária conclui-se que o único possível causador de mudanças genéticas é o DNA porque as outras experiências não mostraram mudanças nos genes dos seres testados."
} 


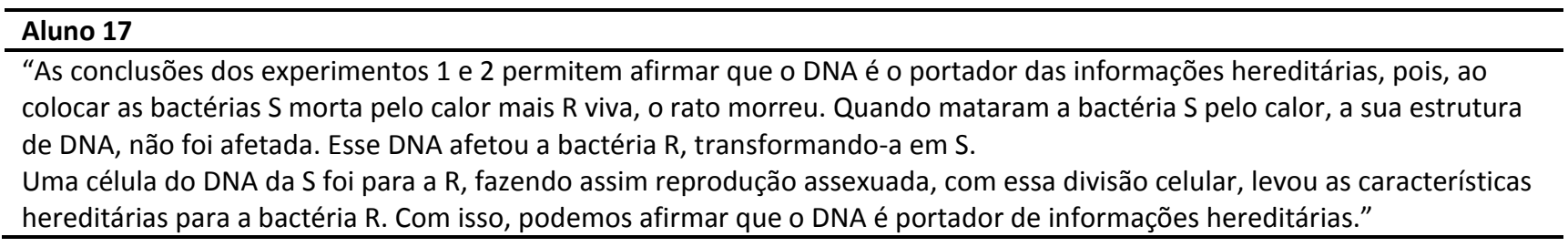

\section{Aluno 17}

Argumento 1

D - [Dado que] As conclusões dos experimentos 1 e 2. assim,

C - permitem afirmar que o DNA é o portador das informações hereditárias.

"Uma célula do DNA da $S$ foi para a $R$, fazendo assim reprodução assexuada, com essa divisão celular, levou as características hereditárias para a bactéria R. Com isso, podemos afirmar que o DNA é portador de informações hereditárias." O trecho contém erros conceituais e há uma causalidade errada devido ao uso da expressão "com isso".

Só é possível construir um argumento que apresenta justificativa. O dado prevê que a justificativa falasse dos dois experimentos, porém o aluno se restringe a uma parte do primeiro experimento. Consideramos essa justificativa fraca. 


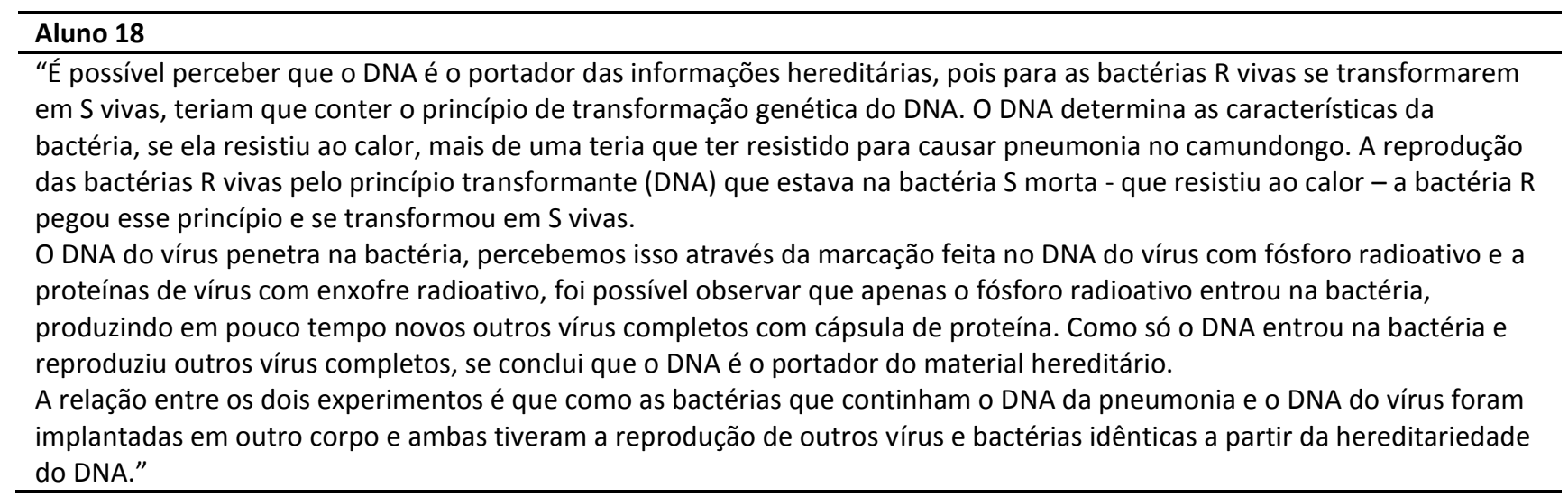

\section{Aluno 18}

\section{Argumento 1}

\begin{tabular}{|l|l|l|}
\hline $\begin{array}{l}\text { D - [Dado que] para as bactérias R vivas } \\
\text { se transformarem em S vivas, teriam que }\end{array}$ & assim, & $\begin{array}{l}\text { C - É possível perceber que o } \\
\text { conter o princípio de transformação } \\
\text { genética do DNA. }\end{array}$
\end{tabular}

Argumento tautológico, pois a informação que justifica a conclusão que justifica a conclusão é a mesma da conclusão.

\section{Argumento 2}

D - [Dado que] O DNA determina as características da bactéria.

assim,

C - mais de uma teria que ter resistido para causar pneumonia no camundongo.

$$
\begin{aligned}
& \text { J - [porque] se } \\
& \text { ela resistiu ao } \\
& \text { calor. }
\end{aligned}
$$

Conclusão e justificativa apresentam conceitos errados, portanto o argumento é desconsiderado.

\section{Argumento 3}

$$
\begin{aligned}
& \text { D - [Dado que] percebemos isso através } \\
& \text { da marcação feita no DNA do vírus com } \\
& \text { fósforo radioativo e a proteínas de vírus } \\
& \text { com enxofre radioativo, foi possível } \\
& \text { observar que apenas o fósforo radioativo } \\
& \text { entrou na bactéria, produzindo em pouco } \\
& \text { tempo novos outros vírus completos com } \\
& \text { cápsula de proteína. }
\end{aligned}
$$

C - O DNA do vírus penetra na bactéria. 
Argumento 4

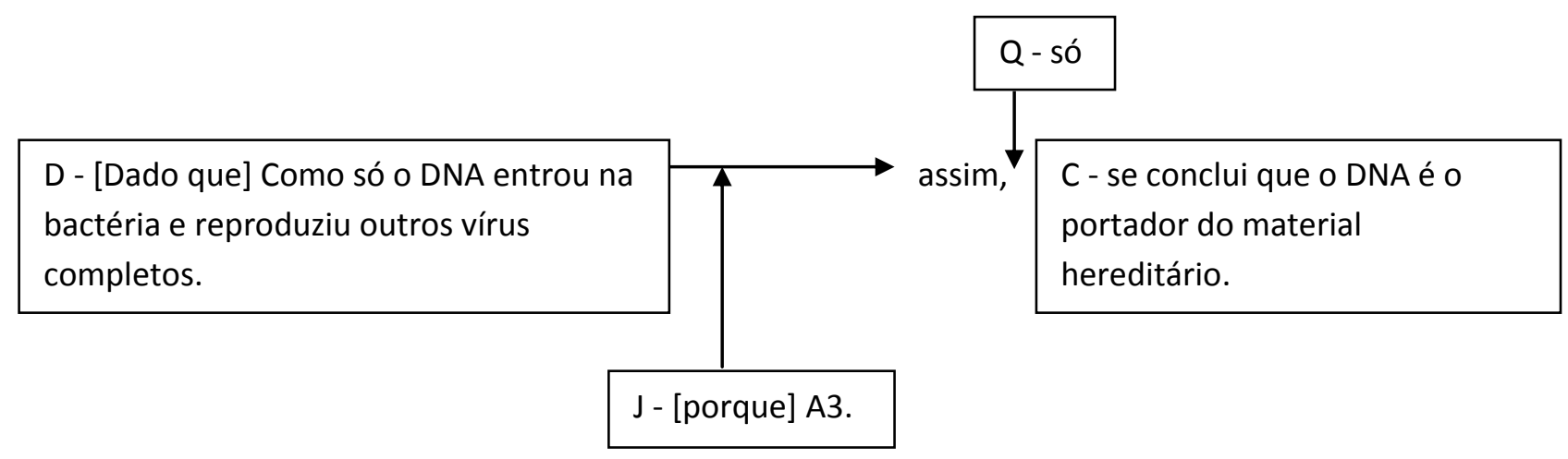

"A reprodução das bactérias $R$ vivas pelo princípio transformante (DNA) que estava na bactéria $S$ morta - que resistiu ao calor - a bactéria $R$ pegou esse princípio e se transformou em $S$ vivas." Afirmação que transforma o argumento 1 em uma verdade, mas não estabelece nenhuma relação com os argumentos anteriores. Está correta conceitualmente, mas não se articula com o texto.

"A relação entre os dois experimentos é que como as bactérias que continham o DNA da pneumonia e o DNA do vírus foram implantadas em outro corpo e ambas tiveram a reprodução de outros vírus e bactérias idênticas a partir da hereditariedade do DNA." O trecho contém afirmação, mas não contém argumento. Traz conceitos relevantes ao tema da questão e se relaciona fortemente à conclusão do enunciado, seria um dado. Como o enunciado contém tal afirmação, o trecho gera dúvida na análise. Por isso, foi retirado.

\footnotetext{
Aluno 19

"O DNA é o portador das informações hereditárias, pois quando a R viva entra na S morta ela se reproduziu formando várias $S$ e faz com que o camundongo morresse. A mesma coisa acontece com o experimento 2, o DNA do vírus penetra e a bactéria se reproduz. O DNA que é a informação hereditária, ele passa por via sexual, dando suas características, isso, podemos dizer que acontece com o ser humano.

As $\mathrm{S}$ se reproduzem, pois elas contém uma cápsula de carboidratos e causam a pneumonia em camundongos, já a $\mathrm{R}$ não produzem a cápsulas de carboidratos e não causam pneumonia em camundongos.

As bactérias filhas $S$ carregam as informações que tem no DNA, pois o DNA dos "pais" tem as informações que elas precisam, para se desenvolver."
} 


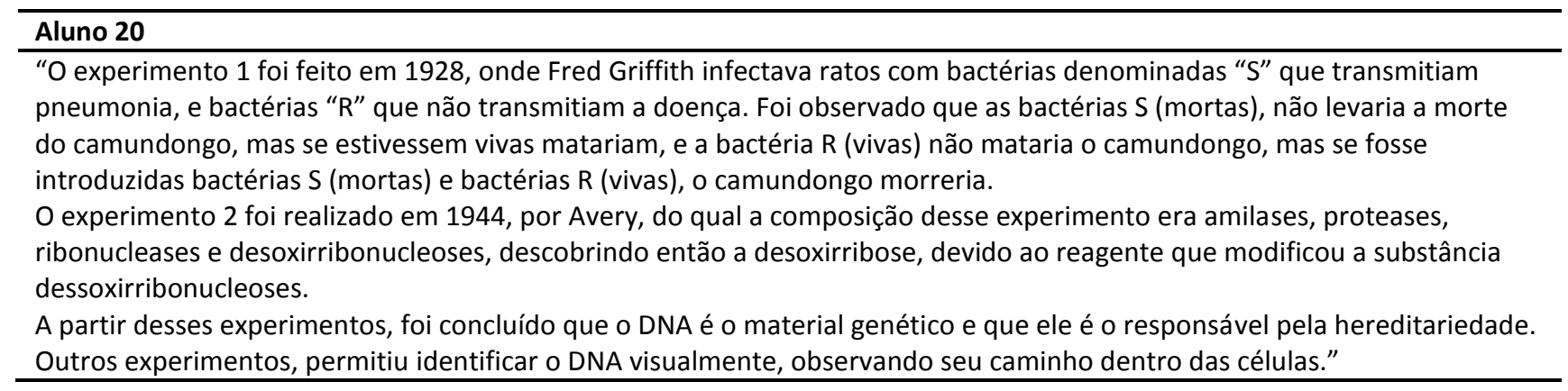

\section{Aluno 20}

Argumento 1

\begin{tabular}{|c|c|c|}
\hline $\begin{array}{l}\text { D - [Dado que] O experimento } 1 \text { foi feito } \\
\text { em } 1928 \text {, onde Fred Griffith infectava } \\
\text { ratos com bactérias denominadas "S" que } \\
\text { transmitiam pneumonia, e bactérias " } R \text { " }\end{array}$ & $\longrightarrow$ assim, & $\begin{array}{l}\text { C - foi concluído que o DNA é o } \\
\text { material genético e que ele é o } \\
\text { responsável pela } \\
\text { hereditariedade. }\end{array}$ \\
\hline
\end{tabular}

observado que as bactérias $S$ (mortas),

não levaria a morte do camundongo, mas

se estivessem vivas matariam, e a

bactéria $\mathrm{R}$ (vivas) não mataria $\mathrm{o}$

camundongo, mas se fosse introduzidas

bactérias $S$ (mortas) e bactérias $R$ (vivas),

o camundongo morreria.

O experimento 2 foi realizado em 1944, por Avery, do qual a composição desse experimento era amilases, proteases, ribonucleases e desoxirribonucleases, descobrindo então a desoxirribose, devido ao reagente que modificou a substância dessoxirribonucleases.

O aluno não deixa clara a relação entre as informações presentes no dado e a conclusão. Há um acúmulo de narrativas sobre os experimentos, ou seja, não há justificativa.

"Outros experimentos, permitiu identificar o DNA visualmente, observando seu caminho dentro das células." Trecho com erro conceitual (tal qual aluno 2).

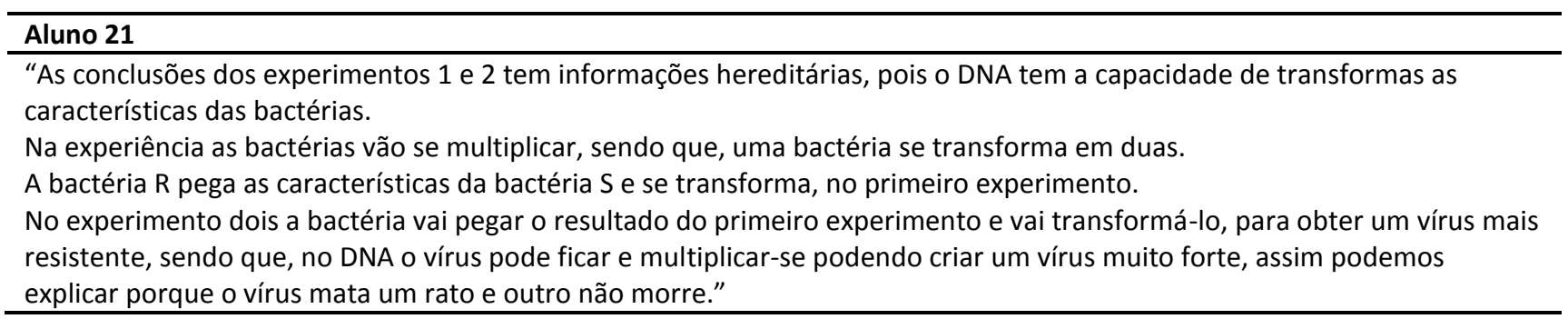




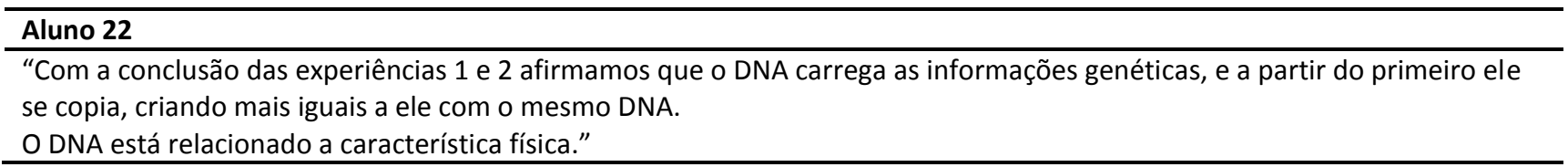

\section{Aluno 22}

Argumento 1

D - [Dado que] Com a conclusão das experiências 1 e 2 .

C - afirmamos que o DNA carrega as informações genéticas.

O argumento formulado é igual ao enunciado da questão, desta vez em forma de afirmação.

"e a partir do primeiro ele se copia, criando mais iguais a ele com o mesmo DNA. O DNA está relacionado a característica física." Afirmações desconectadas que não servem de justificativa nem se relacionam com a pergunta. $\mathrm{O}$ aluno não coloca conectivos que dêem a relação causal. 


\section{Aluno 23}

"Com a conclusão dos experimentos 1 e 2 podemos afirmar que o DNA carrega as informações genéticas, pois a partir dele são criados outros vírus idênticos com capacidade de gerar a mesma doença e se espalhar pelo organismo."

\section{Aluno 23}

\section{Argumento 1}

D - [Dado que] a conclusão dos experimentos 1 e 2 .

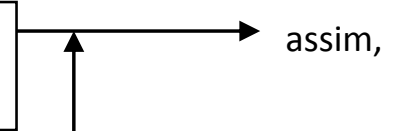

C - podemos afirmar que o DNA carrega as informações genéticas.

J - [porque] a partir dele são criados outros vírus idênticos com capacidade de gerar a mesma doença e se espalhar pelo organismo.

O conectivo "pois" (vide original) expresso cria uma relação de causa, logo, classificamos o trecho como justificativa. Tal justificativa não permite a passagem entre o dado e a conclusão (são informações desconexas), logo, o argumento não pode ser considerado correto. 


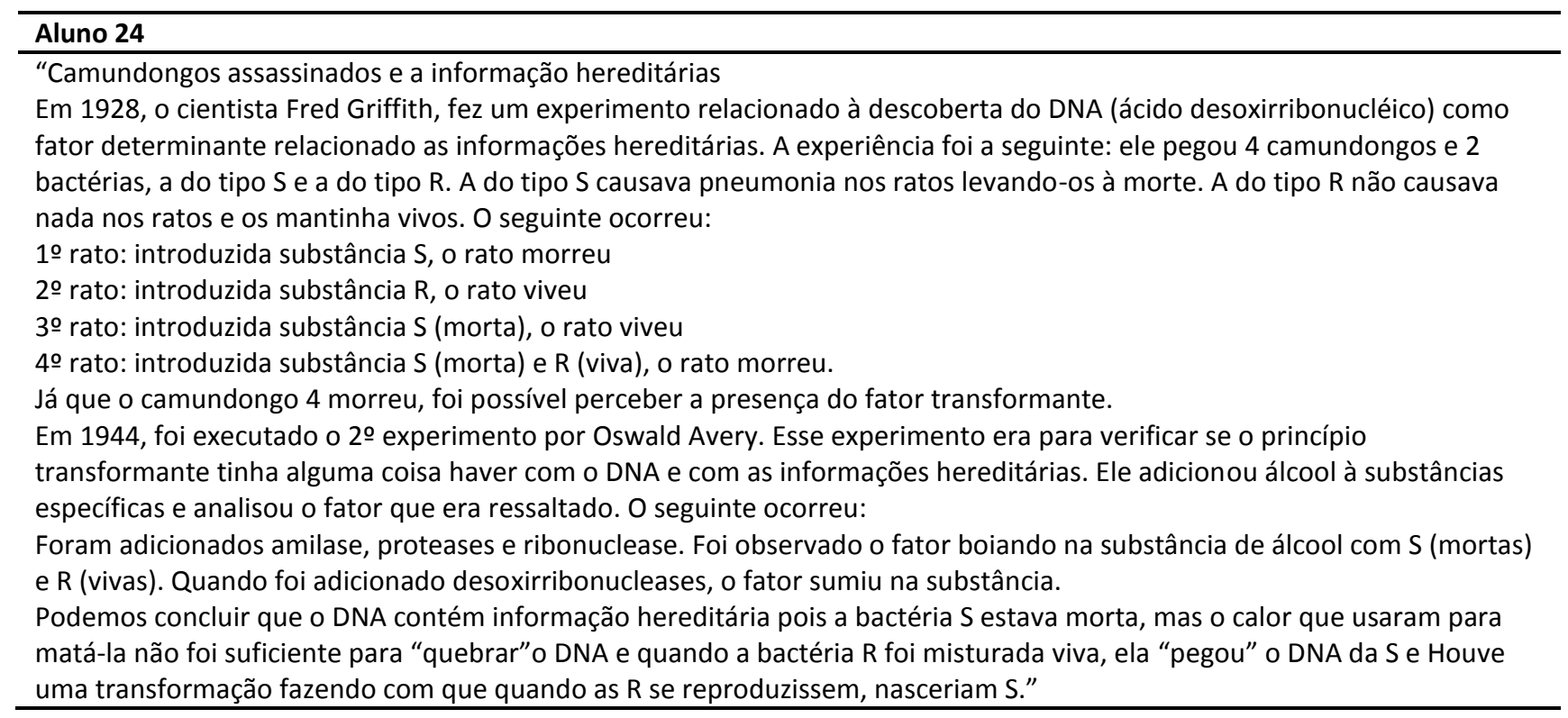

\section{Aluno 24}

\section{Argumento 1}

D - [Dado que] Em 1928, o cientista Fred Griffith, fez um experimento relacionado à descoberta do DNA (ácido desoxirribonucléico) como fator determinante relacionado as informações hereditárias. A experiência foi a seguinte: ele pegou 4 camundongos e 2 bactérias, a do tipo $S$ e a do tipo R. A do tipo $S$ causava pneumonia nos ratos levando-os à morte. $\mathrm{A}$ do tipo $\mathrm{R}$ não causava nada nos ratos e os mantinha vivos. $O$ seguinte ocorreu:

1으 rato: introduzida substância $S$, o rato morreu

2을 rato: introduzida substância $R$, o rato viveu

3ำ rato: introduzida substância S (morta), o rato viveu 4ㅇ rato: introduzida substância S (morta) e $\mathrm{R}$ (viva), o rato morreu. Já que o camundongo 4 morreu.
C - foi possível perceber a presença do fator transformante.

O aluno usa o conectivo "já que" indicando relação, porém, apenas adiciona outro dado repetindo o resultado do experimento. 
Argumento 2

D - [Dado que] a bactéria S estava morta, mas o calor que usaram para matá-la não foi suficiente para "quebrar"o DNA e quando a bactéria $\mathrm{R}$ foi misturada viva, ela "pegou" o DNA da S e Houve uma transformação fazendo com que quando as $\mathrm{R}$ se reproduzissem, nasceriam $\mathrm{S}$.
C - Podemos concluir que o DNA contém informação hereditária.

O aluno tem conteúdo para construir uma justificativa, mas usa conectivos errados ("mas", "e quando"), portanto não cria uma relação de justificativa entre as sentenças.

"Em 1944, foi executado o 20 experimento por Oswald Avery. Esse experimento era para verificar se o princípio transformante tinha alguma coisa haver com o DNA e com as informações hereditárias. Ele adicionou álcool à substâncias específicas e analisou o fator que era ressaltado. O seguinte ocorreu:

Foram adicionados amilase, proteases e ribonuclease. Foi observado o fator boiando na substância de álcool com $S$ (mortas) e $R$ (vivas). Quando foi adicionado desoxirribonucleases, o fator sumiu na substância." Parágrafo narrativo sem conclusões. $O$ aluno apenas enumera informações.

Título: "Camundongos assassinados e a informação hereditárias". Não adiciona informação relevante para a resposta. 


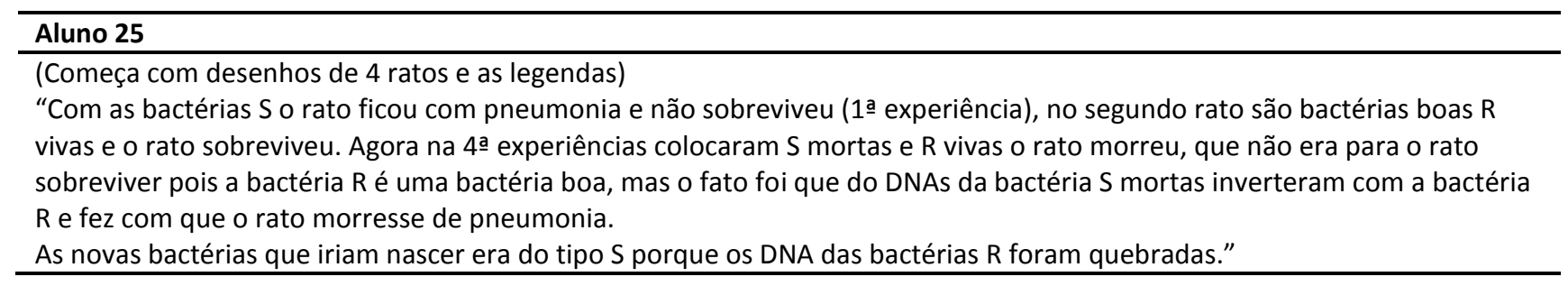

\section{Aluno 25}

Argumento 1

$\mathrm{D}$ - [Dado que] os DNA[s] das bactérias R $\longrightarrow$ assim, $\mathrm{C}$ - As novas bactérias que iriam foram quebradas. nascer era do tipo $\mathrm{S}$.

Há erro conceitual no dado, o que invalida o argumento.

(Começa com desenhos de 4 ratos e as legendas)

"Com as bactérias $S$ o rato ficou com pneumonia e não sobreviveu (1ํa experiência), no segundo rato são bactérias boas $R$ vivas e o rato sobreviveu. Agora na $4 \underline{a}$ experiências colocaram $S$ mortas e $R$ vivas o rato morreu(...)"Não há conclusão, apenas uma enumeração de fatos.

"que não era para o rato sobreviver pois a bactéria $\boldsymbol{R}$ é uma bactéria boa". Tentativa de estabelecer uma justificativa, mas contém erros conceituais.

" mas o fato foi que do DNAs da bactéria $S$ mortas inverteram com a bactéria $R$ e fez com que o rato morresse de pneumonia." Não há conclusão, apenas uma enumeração de fatos. 


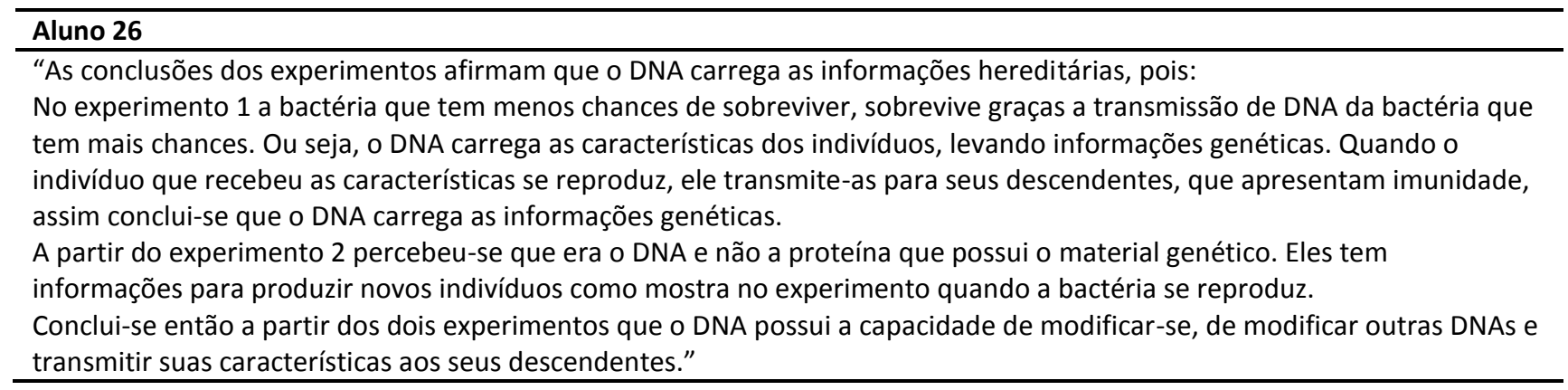

\section{Aluno 26}

Argumento 1

\begin{tabular}{l}
$\begin{array}{l}\text { D - [Dado que] As conclusões dos } \\
\text { experimentos. }\end{array}$ \\
\cline { 2 - 2 }
\end{tabular}

Argumento 2

D - [Dado que] A partir do experimento 2. assim,

C - percebeu-se que era o DNA e não a proteína que possui o material genético.

Argumento 3

D - [Dado que] como mostra no experimento quando a bactéria se reproduz. assim,

C - Eles [DNA] tem informações para produzir novos indivíduos.

\section{Argumento 4}

D - [Dado que] a partir dos dois experimentos.

assim,

C - Conclui-se que o DNA possui

a capacidade de modificar-se, de modificar outras DNAs e transmitir suas características aos seus descendentes.

"pois: No experimento 1 a bactéria que tem menos chances de sobreviver, sobrevive graças a transmissão de DNA da bactéria que tem mais chances. Ou seja, o DNA carrega as características dos indivíduos, levando informações genéticas. Quando o indivíduo que recebeu as características se reproduz, ele transmite-as para seus descendentes, que apresentam imunidade, assim conclui-se que o DNA carrega as informações genéticas." Esse trecho pretendia ser uma justificativa devido ao uso do conectivo pois que precede o parágrafo, mas o aluno apresenta afirmações que não são justificativas e estão incorretas conceitualmente. 


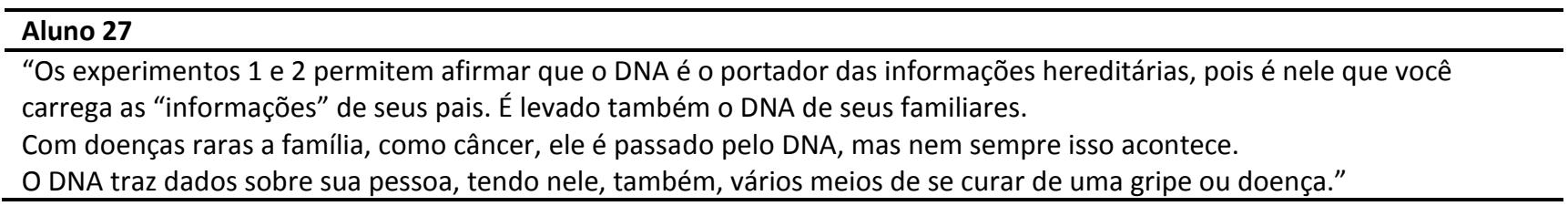

\section{Aluno 27}

\section{Argumento 1}

D - [Dado que] Os experimentos 1 e 2.
C - permitem afirmar que o DNA é o portador das informações hereditárias.

J - [porque] é nele que você carrega as "informações" de seus pais. É levado também o

DNA de seus familiares.

A justificativa apresentada não permite a passagem do dado para a conclusão, apesar de estruturalmente estar correto. É desconsiderado.

"Com doenças raras a família, como câncer, ele é passado pelo DNA, mas nem sempre isso acontece. O DNA traz dados sobre sua pessoa, tendo nele, também, vários meios de se curar de uma gripe ou doença." Afirmações jogadas, sem relação com a pergunta, duvidosas quanto à sua correção conceitual. 


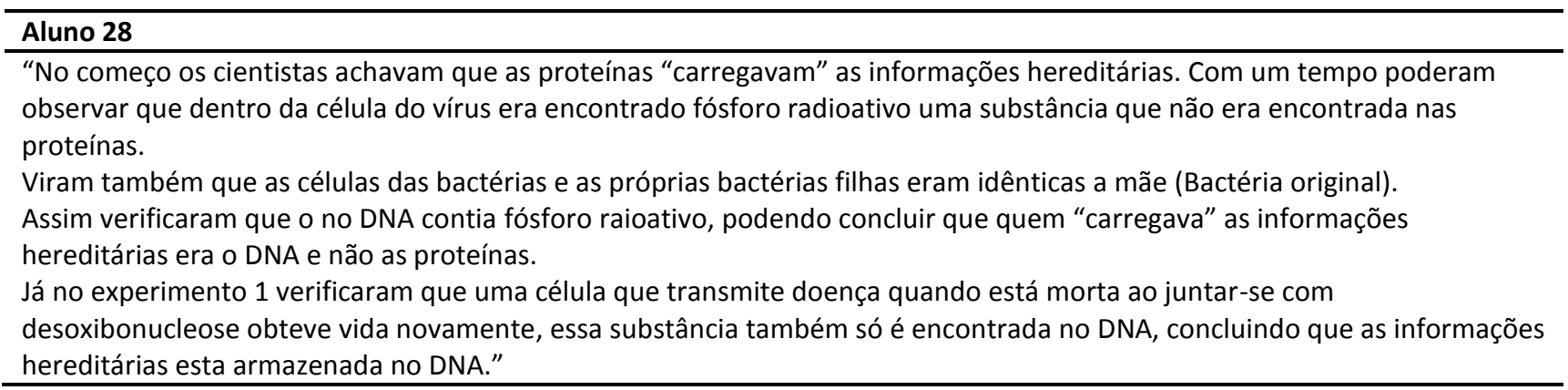

\section{Aluno 28}

Argumento 1

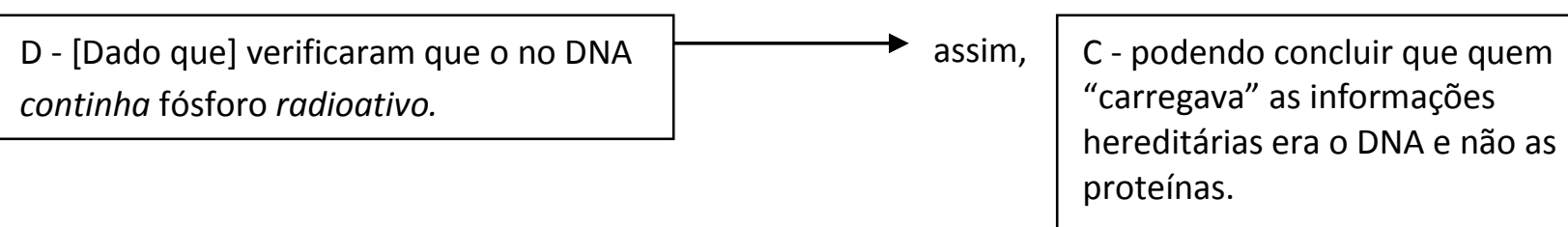

O conectivo "assim" é usado no início do dado, como se a frase fosse consequência do parágrafo anterior.

Argumento 2

\begin{tabular}{|c|c|c|}
\hline $\begin{array}{l}\text { D - [Dado que] Já no experimento } 1 \\
\text { verificaram que uma célula que transmite } \\
\text { doença quando está morta ao juntar-se } \\
\text { com desoxibonuclease obteve vida } \\
\text { novamente. }\end{array}$ & $\longrightarrow$ assim, & $\begin{array}{l}\text { C - concluindo que as } \\
\text { informações hereditárias estão } \\
\text { armazenadas no DNA. }\end{array}$ \\
\hline $\begin{array}{l}\text { J - [porque] } \\
\text { também só } \\
\text { DNA. }\end{array}$ & $\begin{array}{l}\text { ssa substância } \\
\text { encontrada no }\end{array}$ & \\
\hline
\end{tabular}

O dado apresentado está errado conceitualmente e tem caráter místico, pois o DNA obtém vida novamente de maneira inexplicável. Argumento não considerado.

"No começo os cientistas achavam que as proteínas "carregavam" as informações hereditárias." Afirmação solta, sem argumento.

"Com um tempo poderam observar que dentro da célula do vírus era encontrado fósforo radioativo uma substância que não era encontrada nas proteínas." Afirmação solta com erros conceituais.

"Viram também que as células das bactérias e as próprias bactérias filhas eram idênticas a mãe (Bactéria original)." Afirmação solta, sem argumento. 


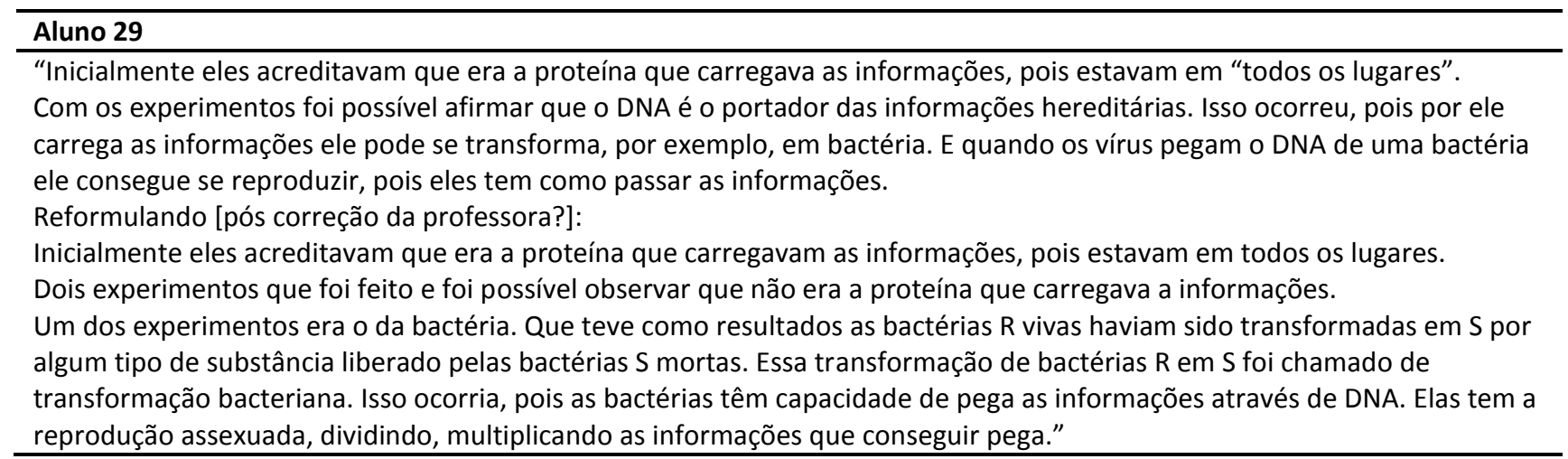

\section{Aluno 29}

Argumento 1

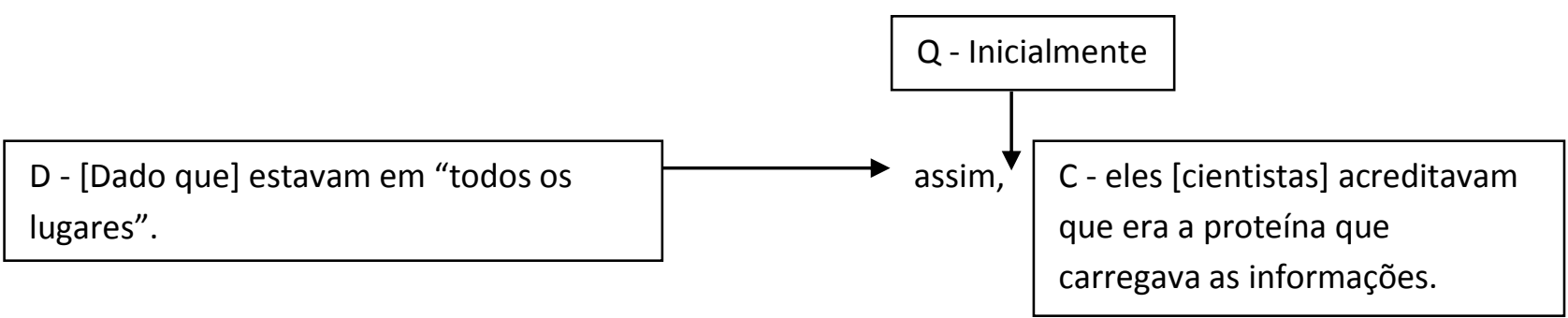

Argumento 2

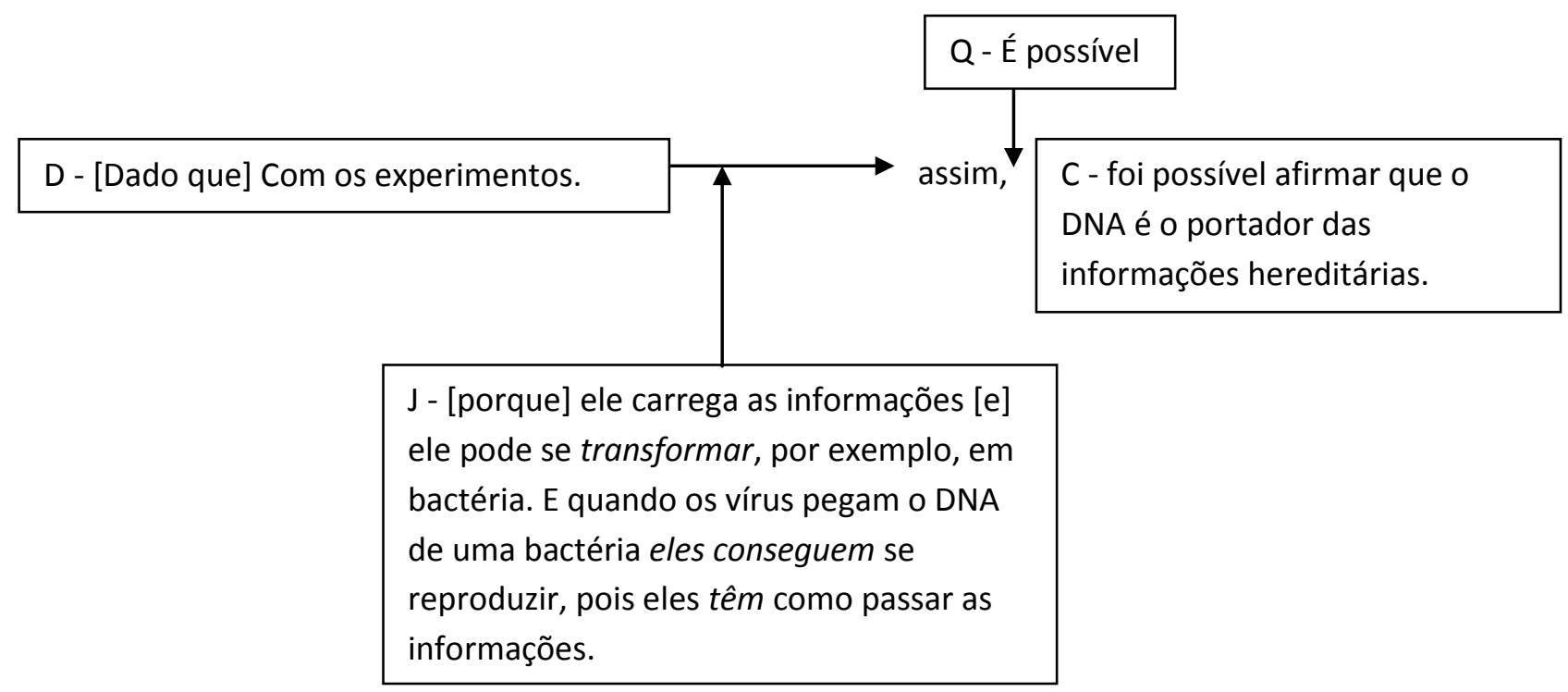

A justificativa apresentada para ligar dado à conclusão está errada conceitualmente, logo, descartamos o argumento.

"Reformulando [após as discussões em pequenos grupos]:" 
Argumento 1

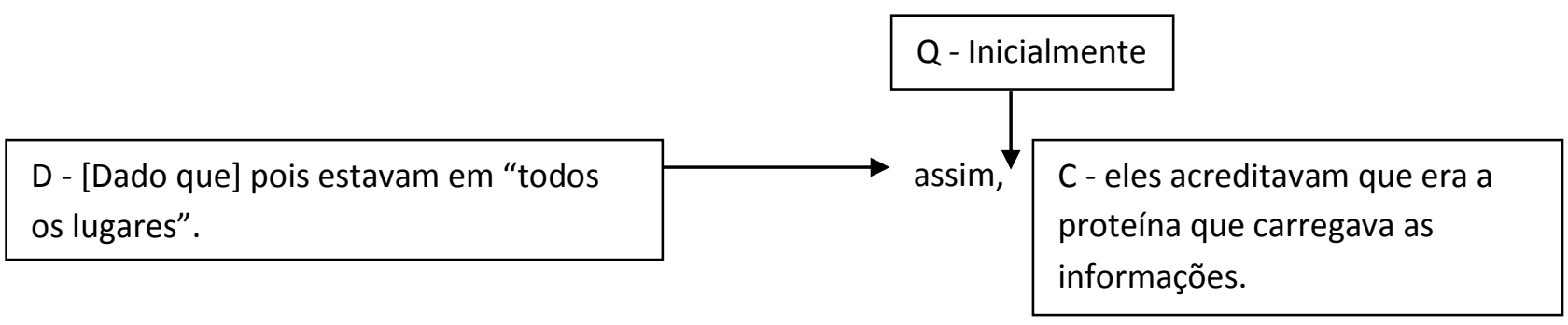

O argumento 1 se repete após a correção do aluno.

"Dois experimentos que foi feito e foi possivel observar que não era a proteína que carregava a informações." Há conteúdo conceitual para estabelecer a relação $D$ logo $C$, mas o conectivo usado não permite tal relação (" $e$ ").

"Um dos experimentos era o da bactéria. Que teve como resultados as bactérias $R$ vivas haviam sido transformadas em $S$ por algum tipo de substância liberado pelas bactérias $S$ mortas. Essa transformação de bactérias $R$ em $S$ foi chamado de transformação bacteriana. Isso ocorria, pois as bactérias têm capacidade de pega as informações através de DNA. Elas tem a reprodução assexuada, dividindo, multiplicando as informações que conseguir pega." Enumeração de fatos e conceitos, mas não há conclusões, logo, não consideramos um argumento, apesar da correção conceitual. 


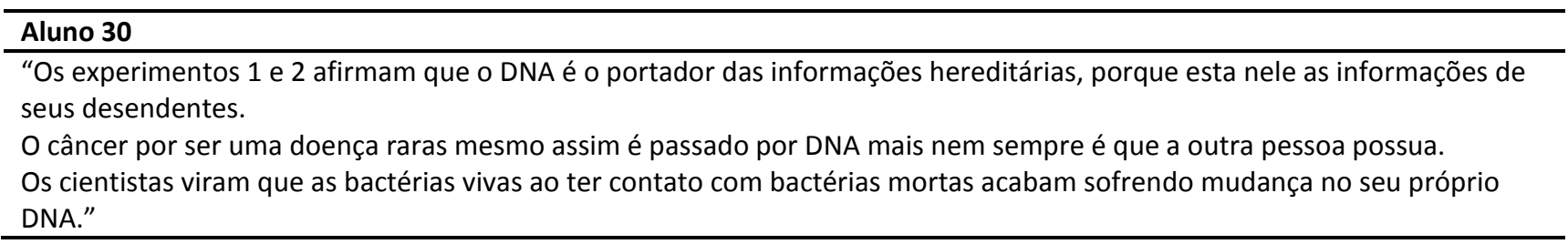

\section{Aluno 30}

Argumento 1

\begin{tabular}{|l|l|l|}
\hline $\mathrm{D}$ - [Dado que] Os experimentos 1 e 2. & $\begin{array}{l}\mathrm{C} \text { - afirmam que o DNA é o } \\
\text { portador das informações } \\
\text { hereditárias. }\end{array}$ \\
$\qquad \begin{array}{l}\mathrm{J} \text { - [porque] esta nele } \\
\text { as informações de seus } \\
\text { descendentes. }\end{array}$ \\
\hline
\end{tabular}

A justificativa não está errada conceitualmente, mas é uma abstração bem distante do resultado dos experimentos e não permite a passagem de dado à cocnlusão.

"O câncer por ser uma doença raras mesmo assim é passado por DNA mais nem sempre é que a outra pessoa possua." Afirmação solta, sem relação com o enunciado da pergunta. A frase é confusa, não dá pra entender direito o que o aluno quer dizer.

"Os cientistas viram que as bactérias vivas ao ter contato com bactérias mortas acabam sofrendo mudança no seu próprio DNA." Afirmação solta, sem conclusão. Se relaciona em conteúdo com a pergunta, mas o aluno não constrói essa relação. 


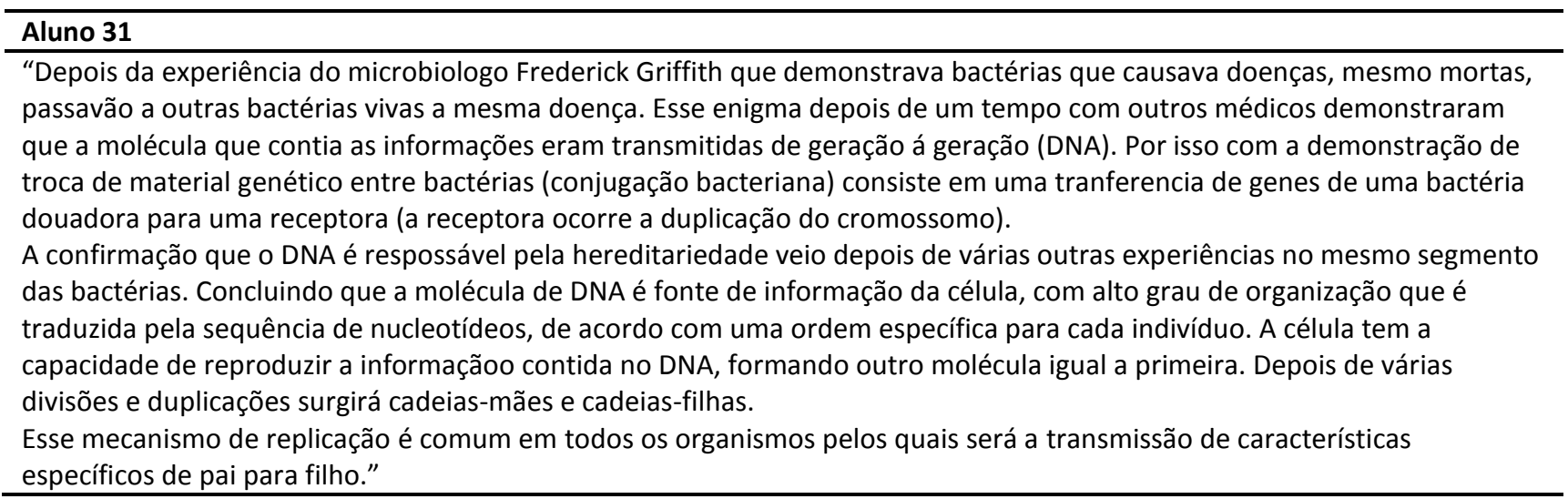

\section{Aluno 31}

Argumento 1

\begin{tabular}{l|l|l|}
\hline $\begin{array}{l}\text { D - [Dado que] Depois da experiência do } \\
\text { micro biólogo Frederick Griffith que } \\
\text { demonstrava [que] bactérias que } \\
\text { causavam doenças, mesmo mortas, } \\
\text { passavam a outras bactérias vivas a }\end{array}$ & assim, & $\begin{array}{l}\text { C - depois de um tempo com } \\
\text { outros médicos demonstraram } \\
\text { que a molécula que continha as } \\
\text { informações eram transmitidas } \\
\text { de geração á geração (DNA). }\end{array}$ \\
\end{tabular}

Não existe relação conceitual entre dado e conclusão.

"Por isso" é usado de forma errada, pois a frase é apenas uma descrição do fenômeno, sem relação com a frase anterior.

"Por isso com a demonstração de troca de material genético entre bactérias (conjugação bacteriana) consiste em uma transferência de genes de uma bactéria doadora para uma receptora (a receptora ocorre a duplicação do cromossomo).

A confirmação que o DNA é responsável pela hereditariedade veio depois de várias outras experiências no mesmo segmento das bactérias. Concluindo que a molécula de DNA é fonte de informação da célula, com alto grau de organização que é traduzida pela sequência de nucleotídeos, de acordo com uma ordem específica para cada indivíduo. A célula tem a capacidade de reproduzir a informação contida no DNA, formando outro molécula igual a primeira. Depois de várias divisões e duplicações surgirá cadeiasmães e cadeias-filhas.

Esse mecanismo de replicação é comum em todos os organismos pelos quais será a transmissão de características específicos de pai para filho." Afirmações descritivas, sem relação com a atividade, os conceitos estão certos. Não responde a questão e não constrói argumentos. 


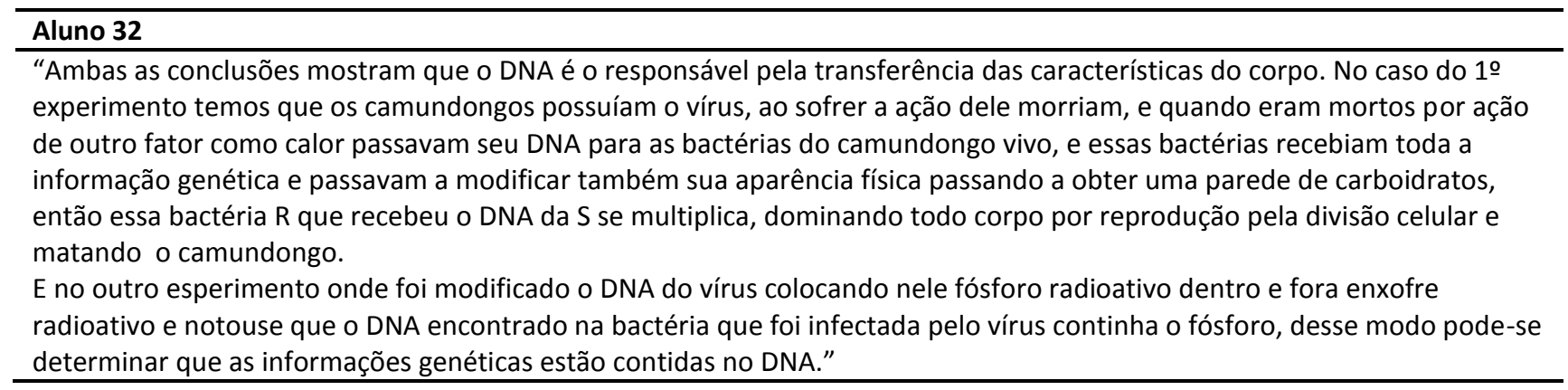

\section{Aluno 32}

Argumento 1

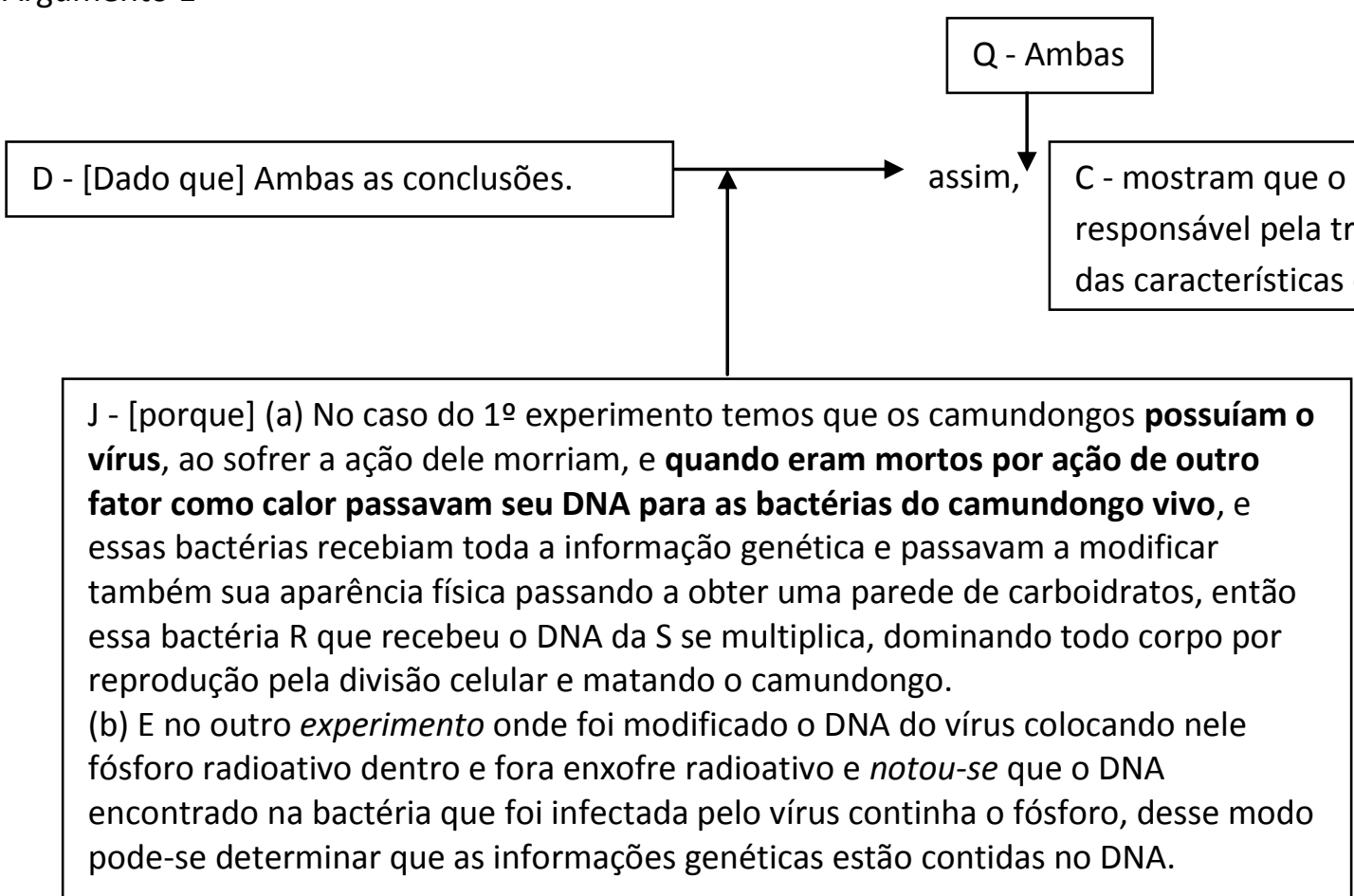

A justificativa tem duas partes. A parte (a) está errada conceitualmente, por isso, invalida o argumento.

Argumento 2

D - [Dado que] E no outro experimento
onde foi modificado o DNA do vírus
colocando nele fósforo radioativo dentro
e fora enxofre radioativo e notou-se que
o DNA encontrado na bactéria que foi
infectada pelo vírus continha o fósforo.

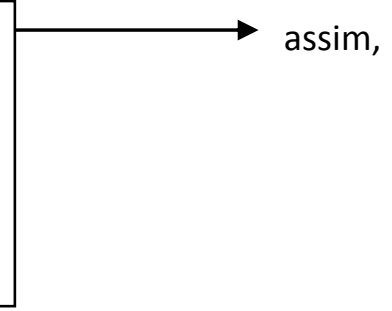

C - desse modo pode-se

determinar que as informações

genéticas estão contidas no

DNA.

O aluno usa o conectivo e indicando relação de soma, ou seja, dois dados ao invés da relação causal, que indicaria justificativa do argumento.

\footnotetext{
Aluno 33

"No experimento 1 há duas características principais nas bactérias que são R, que não são prejudiciais, obtém o DNA das bactérias $\mathrm{S}$ mortas que, ao se dividir as bactérias $\mathrm{R}$, iram matar o camundongo. Já o segundo experimento o vírus bacteriano passa suas informações para a bactéria, aí até as bactérias morrerem."
} 


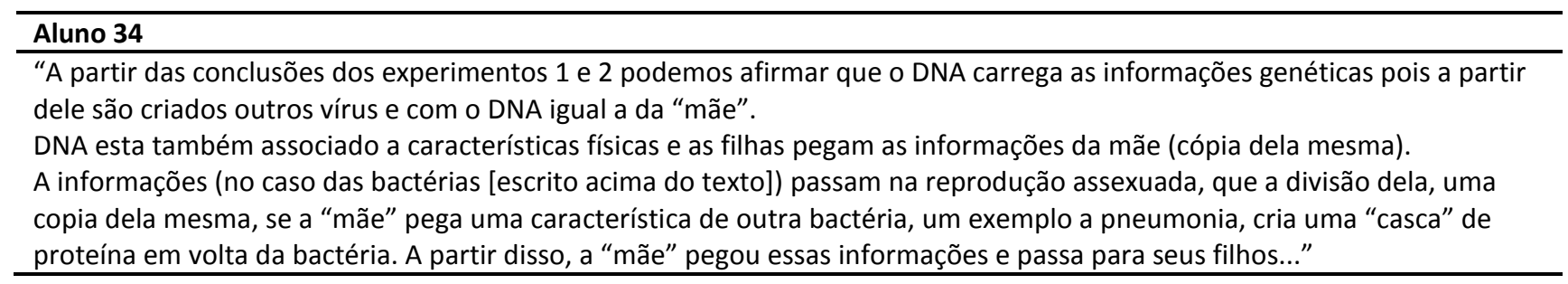

\section{Aluno 34}

Argumento 1

\begin{tabular}{|c|c|c|}
\hline $\begin{array}{l}\text { D - [Dado que] A partir das conclusões } \\
\text { dos experimentos } 1 \text { e } 2 \text {. }\end{array}$ & assim, & $\begin{array}{l}\text { C - podemos afirmar que o DNA } \\
\text { carrega as informações }\end{array}$ \\
\hline $\begin{array}{l}\text { J - [po } \\
\text { criado } \\
\text { DNA i६ }\end{array}$ & $\begin{array}{l}\text { a partir dele são } \\
\text { tros vírus e com o } \\
\text { a da "mãe". }\end{array}$ & \\
\hline
\end{tabular}

A justificativa apresentada não permite a passagem do dado à conclusão.

"DNA esta também associado a características físicas e as filhas pegam as informações da mãe (cópia dela mesma).

A informações (no caso das bactérias [escrito acima do texto]) passam na reprodução assexuada, que a divisão dela, uma copia dela mesma, se a "mãe" pega uma característica de outra bactéria, um exemplo a pneumonia, cria uma "casca" de proteína em volta da bactéria. A partir disso, a "mãe" pegou essas informações e passa para seus filhos..." Afirmações descritivas de processos celulares sem argumento. Apresenta confusões conceituais. 


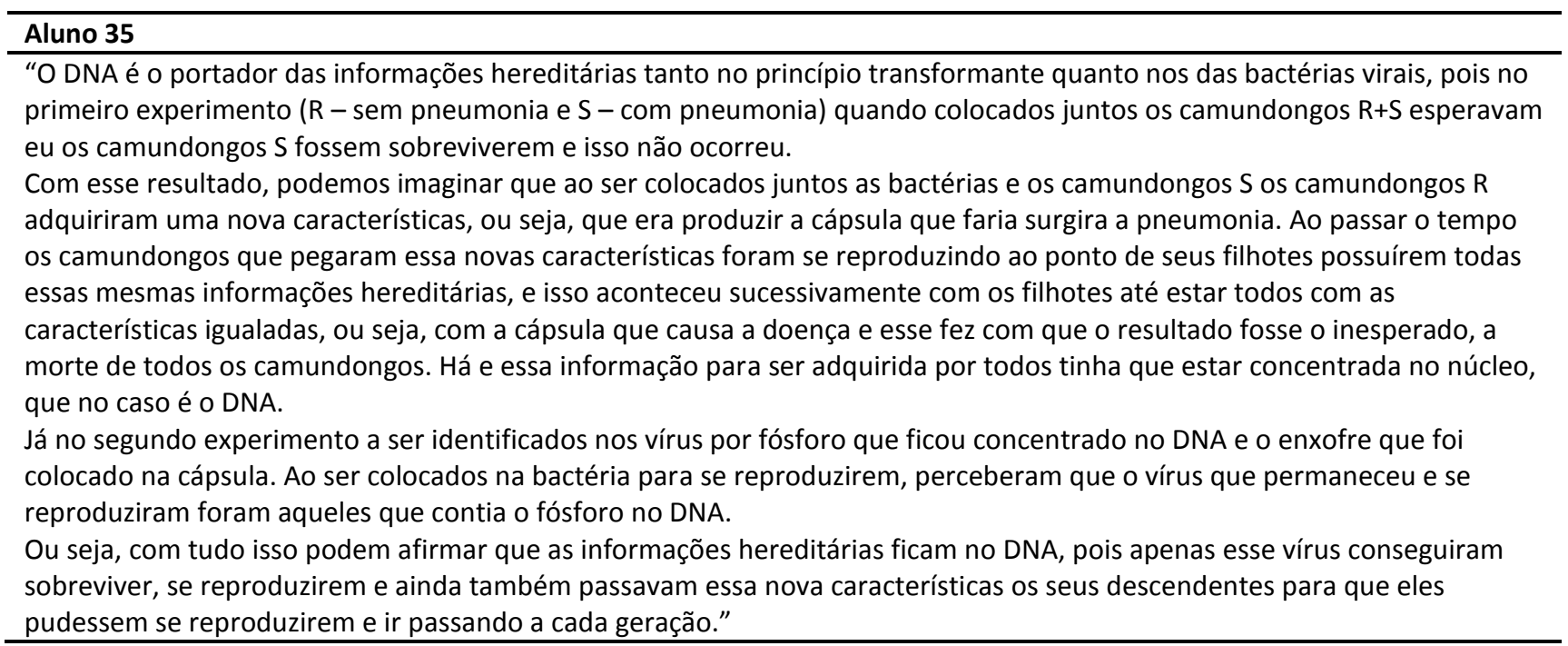

\section{Aluno 35}

Argumento 1

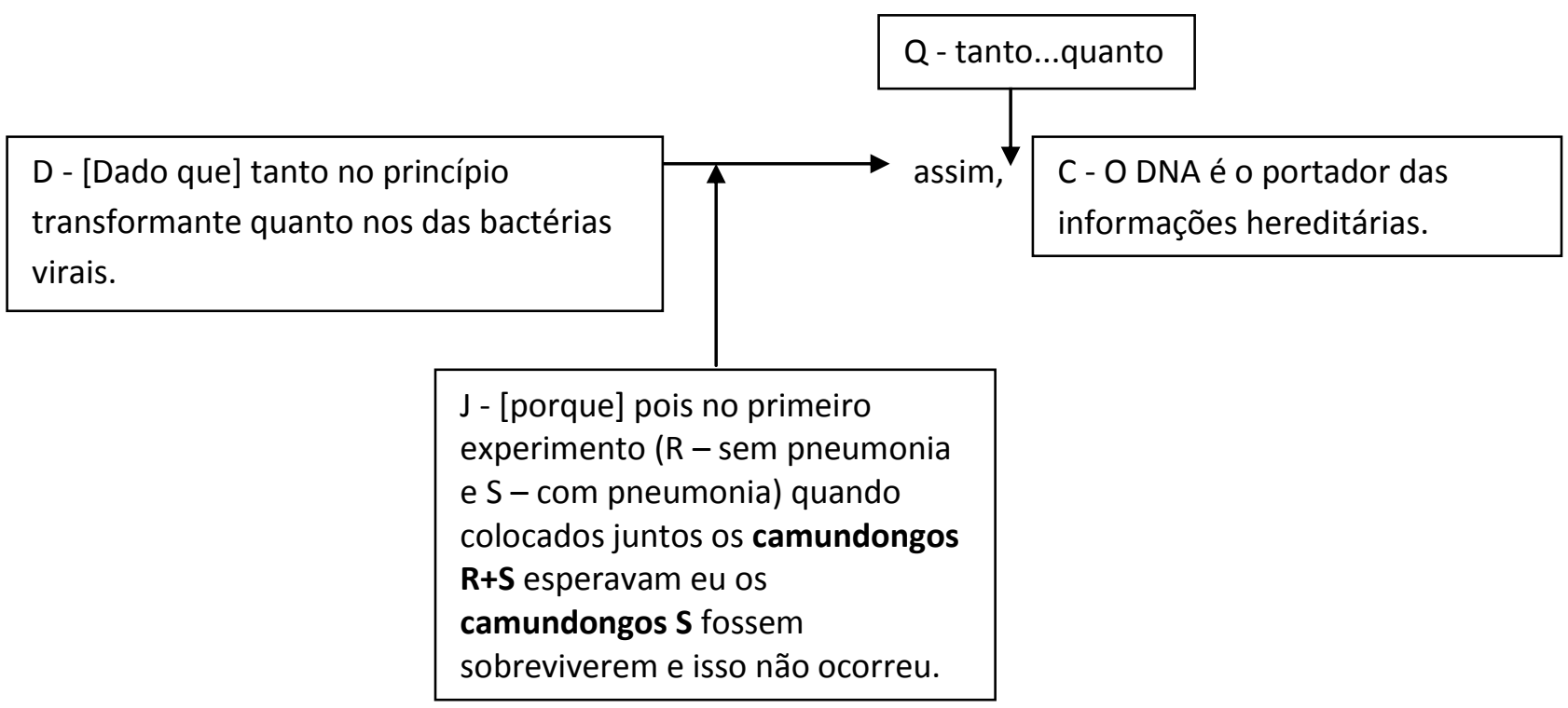

A justificativa apresentada tem erros conceituais que invalidam o argumento. Além disso, apesar de explicitar no dado a presença de 2 experimentos, na garantia, só explicita um deles.

\section{Argumento 2}

\begin{tabular}{|l|l|l}
$\begin{array}{l}\text { D - [Dado que] Ou seja, com tudo isso [se } \\
\text { remete ao parágrafo anterior]. }\end{array}$ & $\begin{array}{l}\text { C - podem afirmar que as } \\
\text { informações hereditárias ficam } \\
\text { no DNA. }\end{array}$ \\
\hline
\end{tabular}

$\mathrm{J}$ - [porque] apenas esse vírus conseguiram sobreviver, se reproduzirem e ainda também passavam essa nova características os seus descendentes para que eles pudessem se reproduzirem e ir passando a cada geração. 
Há conceitos errados na justificativa. Não há relação entre as informações de D, W e C. O trecho da garantia representa um qualificador, porém, como as informações de W e C são desconexas, não tem como inserir o qualificador apenas no modelo de argumento montado.

"Com esse resultado, podemos imaginar que ao ser colocados juntos as bactérias $e$ os camundongos $\boldsymbol{S}$ os camundongos $\boldsymbol{R}$ adquiriram uma nova características, ou seja, que era produzir a cápsula que faria surgira a pneumonia. Ao passar o tempo os camundongos que pegaram essa novas características foram se reproduzindo ao ponto de seus filhotes possuírem todas essas mesmas informações hereditárias, e isso aconteceu sucessivamente com os filhotes até estar todos com as características igualadas, ou seja, com a cápsula que causa a doença e esse fez com que o resultado fosse o inesperado, a morte de todos os camundongos. Há e essa informação para ser adquirida por todos tinha que estar concentrada no núcleo, que no caso é o DNA.

Já no segundo experimento a ser identificados nos vírus por fósforo que ficou concentrado no DNA e o enxofre que foi colocado na cápsula. Ao ser colocados na bactéria para se reproduzirem, perceberam que o vírus que permaneceu e se reproduziram foram aqueles que contia o fósforo no DNA." Há erros conceituais, não é possível identificar as relações criadas entre as afirmações colocadas. 


\section{Apêndices}

Apêndice 01 - Análises dos argumentos produzidos pelos alunos

\begin{tabular}{|c|c|c|c|c|c|c|c|c|}
\hline Aluno & Argumento & $\begin{array}{l}\text { Validade } \\
\text { conceitual }\end{array}$ & $\begin{array}{l}\text { Conclusão do } \\
\text { argumento }\end{array}$ & Descrição dado no argumento & $\begin{array}{l}\text { Trata de quais } \\
\text { experimentos no seu } \\
\text { argumento }\end{array}$ & $\begin{array}{l}\text { Apresenta } \\
\text { justificativa }\end{array}$ & $\begin{array}{l}\text { Cumpre a } \\
\text { tarefa }\end{array}$ & Observações \\
\hline \multirow[t]{3}{*}{1} & A1 & Válido & Esperada & Narra os experimentos & 1 & Sim & Sim & \\
\hline & $\mathrm{A} 2$ & Válido & Esperada & Conclusão dos experimentos & 2 & Sim & & \\
\hline & A3 & Válido & Esperada & Outro & 1 e 2 & Sim & & \\
\hline \multirow[t]{3}{*}{2} & A1 & Válido & Não esperada & Narra os experimentos & 1 & Não & Não & \\
\hline & $\mathrm{A} 2$ & Válido & Não esperada & Conclusão dos experimentos & 1 & Sim & & \\
\hline & A3 & Válido & Esperada & Cita os experimentos & 1 & Não & & \\
\hline \multirow[t]{2}{*}{3} & A1 & Válido & Esperada & Cita os experimentos & 1 & Sim & Não & \\
\hline & $\mathrm{A} 2$ & Válido & Esperada & Outro & - & Sim & & \\
\hline \multirow[t]{3}{*}{4} & A1 & Válido & Esperada & Cita os experimentos & 1 & Sim & Sim & \\
\hline & $\mathrm{A} 2$ & Válido & Não esperada & Outro & 2 & Não & & \\
\hline & $\mathrm{A} 3$ & Válido & Esperada & Outro & 1 e 2 & Não & & \\
\hline \multirow[t]{3}{*}{5} & A1 & Válido & Não esperada & Outro & 1 & Sim & Não & \\
\hline & $\mathrm{A} 2$ & Válido & Não esperada & Narra os experimentos & 1 & Sim & & \\
\hline & A3 & Válido & Esperada & Cita os experimentos & 1 & Sim & & \\
\hline 6 & A1 & Válido & Esperada & Conclusão dos experimentos & 1 & Sim & Não & \\
\hline \multirow[t]{2}{*}{7} & A1 & Inválido & Esperada & Conclusão dos experimentos & 1 & Sim & Não & \\
\hline & $\mathrm{A} 2$ & Válido & Esperada & Conclusão dos experimentos & 2 & Não & & \\
\hline \multirow[t]{3}{*}{8} & A1 & Válido & Não esperada & Outro & - & Não & Sim & \\
\hline & $\mathrm{A} 2$ & Válido & Esperada & Conclusão dos experimentos & 2 & Não & & \\
\hline & A3 & Válido & Esperada & Conclusão dos experimentos & 1 & Não & & \\
\hline \multirow[t]{2}{*}{9} & A1 & Válido & Não esperada & Conclusão dos experimentos & 1 & Não & Sim & \\
\hline & $\mathrm{A} 2$ & Válido & Esperada & Outro & 1 & Sim & & \\
\hline
\end{tabular}




\begin{tabular}{|c|c|c|c|c|c|c|c|c|}
\hline & A3 & Válido & Não esperada & Conclusão dos experimentos & 2 & Sim & & \\
\hline & A4 & Válido & Esperada & Narra os experimentos & 2 & Não & & \\
\hline 11 & A1 & Válido & Esperada & Cita os experimentos & 1 e 2 & Sim & Sim & \\
\hline 12 & A1 & Válido & Esperada & Narra os experimentos & 1 e 2 & Sim & Sim & \\
\hline 13 & A1 & Válido & Esperada & Narra os experimentos & 1 & Sim & Não & \\
\hline 14 & A1 & Válido & Esperada & Narra os experimentos & 1 & Sim & Não & \\
\hline \multirow{2}{*}{15} & $\mathrm{~A} 2$ & Válido & Não esperada & Cita os experimentos & 2 & Não & & \\
\hline & A3 & Válido & Esperada & Cita os experimentos & 1 e 2 & Não & & \\
\hline 17 & A1 & Válido & Esperada & Cita os experimentos & 1 & Sim & Não & \\
\hline \multirow[t]{2}{*}{18} & A1 & Válido & Esperada & Conclusão dos experimentos & 1 & Não & Sim & \\
\hline & A2 & Inválido & Não esperada & Outro & 1 & Sim & & \\
\hline 23 & $\mathrm{~A} 1$ & Inválido & Esperada & Cita os experimentos & 2 & Sim & Não & \\
\hline \multirow[t]{2}{*}{24} & A1 & Válido & Não esperada & Narra os experimentos & 1 & Não & Não & \\
\hline & A2 & Válido & Esperada & Conclusão dos experimentos & 1 & Não & & \\
\hline 25 & A1 & Inválido & Não esperada & Outro & 1 & Não & Não & \\
\hline \multirow[t]{2}{*}{26} & A1 & Válido & Esperada & Cita os experimentos & 1 e 2 & Não & Sim & $\begin{array}{l}\text { não tem } \\
\text { justificativa, é } \\
\text { cópia do } \\
\text { enunciado }\end{array}$ \\
\hline & A2 & Válido & Não esperada & Cita os experimentos & 2 & Não & & \\
\hline
\end{tabular}




\begin{tabular}{|c|c|c|c|c|c|c|c|c|}
\hline & A4 & Válido & Esperada & Cita os experimentos & 1 e 2 & Não & & $\begin{array}{l}\text { não tem } \\
\text { justificativa, é } \\
\text { cópia do } \\
\text { enunciado }\end{array}$ \\
\hline 27 & A1 & Inválido & Esperada & Cita os experimentos & - & Sim & Não & \\
\hline \multirow[t]{2}{*}{28} & A1 & Válido & Esperada & Conclusão dos experimentos & 2 & Não & Não & \\
\hline & $\mathrm{A} 2$ & Inválido & Esperada & Conclusão dos experimentos & 1 & Sim & & \\
\hline \multirow[t]{3}{*}{29} & A1 & Válido & Não esperada & Outro & 1 & Não & Não & \\
\hline & $\mathrm{A} 2$ & Inválido & Esperada & Cita os experimentos & 1 & Sim & & \\
\hline & $\mathrm{A} 3$ & Válido & Não esperada & Outro & 1 & Não & & \\
\hline 30 & A1 & Inválido & Esperada & Cita os experimentos & - & Sim & Não & \\
\hline 31 & A1 & Inválido & Esperada & Narra os experimentos & 1 & Não & Não & \\
\hline \multirow[t]{2}{*}{32} & A1 & Inválido & Esperada & Conclusão dos experimentos & 1 e 2 & Sim & Não & $\begin{array}{l}\text { a justificativa do } \\
\text { experimento } 1 \text { é } \\
\text { errada } \\
\text { conceitualmente }\end{array}$ \\
\hline & $\mathrm{A} 2$ & Válido & Esperada & Narra os experimentos & 2 & Não & & \\
\hline 34 & A1 & Válido & Esperada & Cita os experimentos & 2 & Sim & Não & \\
\hline \multirow[t]{2}{*}{35} & A1 & Inválido & Esperada & Cita os experimentos & 1 & Sim & Não & \\
\hline & $\mathrm{A} 2$ & Inválido & Esperada & Narra os experimentos & 1 & Sim & & \\
\hline
\end{tabular}




\section{Apêndice 02 - Transcrição de aula $3^{\circ} \mathrm{I}$}

\begin{tabular}{|c|c|c|c|c|c|}
\hline Linha & Tempo & Pessoa & Falas & $\begin{array}{l}\text { Ações pró- } \\
\text { argumentação }\end{array}$ & Observações \\
\hline 1 & 00:00:06 & & & & $\begin{array}{l}\text { Alunos entram na } \\
\text { sala }\end{array}$ \\
\hline 2 & 00:01:30 & & & & $\begin{array}{l}\text { Alunos do fundo } \\
\text { esquerdo da sala } \\
\text { terminam de fazer } \\
\text { e comentam o } \\
\text { exercício }\end{array}$ \\
\hline 3 & 00:03:00 & & & & $\begin{array}{l}\text { Alunos comentam } \\
\text { o exercício }\end{array}$ \\
\hline 4 & 00:04:10 & & & & $\begin{array}{l}\text { Professora } \\
\text { começa a } \\
\text { organizar a sala. } \\
\text { Vai até a porta e } \\
\text { chama os alunos }\end{array}$ \\
\hline 5 & 00:04:46 & & & & $\begin{array}{l}\text { Professora fecha a } \\
\text { porta }\end{array}$ \\
\hline 6 & $00: 05: 13$ & $\mathrm{P}$ & Pessoal, vamos lá? & & \\
\hline 7 & $00: 05: 17$ & $A$ & Professora & & \\
\hline 8 & $00: 05: 21$ & $A$ & Professora & & \\
\hline 9 & & $P$ & $\mathrm{Oi}$ & & \\
\hline 10 & & $A$ & $\begin{array}{l}\text { É pra entregar essa folha aqui junto, ou só essa aqui } \\
\text { óh? }\end{array}$ & & $\begin{array}{l}\text { Mostra duas } \\
\text { folhas com os } \\
\text { braços levantados }\end{array}$ \\
\hline 11 & & $P$ & Pode ser só essa & & \\
\hline 12 & $00: 05: 30$ & $\mathrm{P}$ & Pessoal, bom dia. Vamos lá? & & \\
\hline 13 & & $A$ & Professora (inaudível) & & \\
\hline 14 & & $P$ & (inaudível) mas acontece & & \\
\hline 15 & & $P$ & $\begin{array}{l}\text { Mas e aí? Vocês fizeram? Vamos entregando a lição. } \\
\text { Síndromes (inaudível) }\end{array}$ & & \\
\hline 16 & & $P$ & $\begin{array}{l}\text { E aí gente? (inaudível) o nome da doença e } \\
\text { (inaudível) sexo (inaudível) }\end{array}$ & & \\
\hline 17 & & $\mathrm{P}$ & Pessoal, todo mundo identificou a questão? & & \\
\hline 18 & & A & Professora. (inaudível) & & \\
\hline 19 & & $\mathrm{P}$ & Klinefelter & & \\
\hline 20 & 00:07:09 & $\mathrm{P}$ & Foi só (inaudível) & & \\
\hline 21 & $00: 08: 27$ & $\mathrm{P}$ & Pessoal, todo mundo entregou? & & \\
\hline 22 & 00:08:57 & $\mathrm{P}$ & $\begin{array}{l}\text { Pessoal, todo mundo identificou o cariótipo? Era o } \\
\text { quê? }\end{array}$ & & \\
\hline 23 & & $A$ & Masculino, normal. & & \\
\hline 24 & & $\mathrm{P}$ & Masculino, normal. O cariótipo 2. & & \\
\hline 25 & & $A$ & Masculino. & & \\
\hline 26 & & $P$ & $\begin{array}{l}\text { Masculino, síndrome de Down, tudo bem. Tem três } \\
\text { cromossomos } 21\end{array}$ & & \\
\hline 27 & & $A$ & Vinte e um & & \\
\hline 28 & & $P$ & Ah, legal que foi feito (?) & & \\
\hline 29 & & $A$ & Ah, acho que eu colei no lugar errado. & & \\
\hline 30 & & $P$ & E o três, o quatro, cariótipo quatro. & & \\
\hline 31 & & $A$ & (inaudível) masculino (...) Klinefelter & & \\
\hline 32 & & $P$ & $\begin{array}{l}\text { Masculino, mas síndrome de Klinefelter, né? Tudo } \\
\text { bem? }\end{array}$ & & \\
\hline 33 & & $A$ & Masculino & & \\
\hline 34 & & $\mathrm{P}$ & É do sexo masculino & & \\
\hline
\end{tabular}




\begin{tabular}{|c|c|c|c|}
\hline 35 & & A & Porque tem um Y \\
\hline 36 & & $\mathrm{P}$ & Só que ele tem uma síndrome chamada Síndrome \\
\hline 37 & & A & (inaudivel) só dois $\mathrm{X}$ \\
\hline 38 & & $P$ & $\begin{array}{l}\text { Não, mas a questão é (...) A determinação, tem o Y } \\
\text { é masculino. Não tem, tanto é que lembra aquele } \\
\text { que só tem um X? É feminino. Só que também é a } \\
\text { Síndrome de Turner que é o XO. Tem o X e não tem } \\
\text { o outro X. }\end{array}$ \\
\hline 39 & 00:10:13 & $\mathrm{P}$ & Tudo bem? \\
\hline 40 & & $\mathrm{P}$ & Então gente, Ãh (...) a gente, até agora (...) \\
\hline 41 & $00: 10: 29$ & $\mathrm{P}$ & $\begin{array}{l}\text { A organização da (...) A organização dos } \\
\text { cromossomos no núcleo, ou cromatina, né? O DNA }\end{array}$ \\
\hline 42 & 00:11:51 & $\mathrm{P}$ & $\begin{array}{l}\text { É, então vimos, é, vimos que a célula contém o } \\
\text { núcleo, dentro do núcleo está o material genético. } \\
\text { Esse material genético é o DNA e esse DNA está } \\
\text { organizado na forma de fio de DNA enrolado em } \\
\text { proteínas e pode ter o nome de cromatina se um } \\
\text { pouco mais esticado ou cromossomo durante a } \\
\text { divisão celular um pouco mais compactado, certo? }\end{array}$ \\
\hline 43 & $00: 12: 23$ & $\mathrm{P}$ & $\begin{array}{l}\text { É (...) E hoje, a aula de hoje, a gente vai falar sobre a } \\
\text { estrutura mais densa do DNA e identificar a } \\
\text { estrutura toda dessa molécula de DNA a partir das } \\
\text { descobertas dos cientistas na história da ciência, } \\
\text { com esse resuminho que eu fiz pra vocês nessa } \\
\text { parte. }\end{array}$ \\
\hline 44 & $00: 13: 10$ & $\mathrm{P}$ & $\begin{array}{l}\text { Então. Como é que os cientistas identificaram a } \\
\text { molécula de DNA? }\end{array}$ \\
\hline 45 & $00: 13: 23$ & $\mathrm{P}$ & $\begin{array}{l}\text { Não. (inaudível) extraem o DNA, né? Mas como é } \\
\text { que na história da ciência, eles identificaram a } \\
\text { composição desse DNA? }\end{array}$ \\
\hline
\end{tabular}

46

00:13:42 P

47

00:13:59 P

48

49

50

51

00:15:02 P

52

00:15:13 P

Pessoal, Shhh!, Vamos lá? Então, vamos seguir esse resumo. OW, eu fiz isso daqui e quero atenção.

Então gente, além da ficha, caderno. Porque essa ficha é um resumo dos principais itens que eu pus (inaudível) Então, determinação dos componentes do núcleo. Essa foi a primeira etapa dessa história para se determinar a estrutura do DNA. Por quê?

Lá, a gente viu nas aulas passadas, discutindo lá a teoria celular, né? Então lá no final do século XIX, já se sa(bia), já se considerava, já se aceitava a ideia como uma verdade acima de qualquer suspeita que todos os seres vivos são formados por células. $\mathrm{E}$ essas células contém núcleo e que ãh (...)

Só que, do que é que é formada as estruturas celulares? Lá no final do século XIX, já se sabia, já se conhecia um pouco das proteínas. $E$ já se sabia que as proteínas estavam em todos os lugares da célula. Tanto é que eles acreditavam, nessa época, que eram as proteínas que continham as informações hereditárias, as informações que passam de uma geração para a outra.

Por exemplo, nessa (inaudível), então é bom vocês acrescentarem (inaudível), né Maria? Então senta direitinho, guarda seu papel.
A informação era quê? Eles achavam que eram as proteínas que tinham as informações hereditárias.
Não completa a

frase

Alguns alunos

falam antes e no meio da fala da professora, mas não dá pra entender. Dá bronca nos alunos. 
Eles começaram a dar muita importância pras proteínas porque tinha proteínas em todos os lugares das células, né?

Então eles achavam que (inaudivel) que continham as informações hereditárias, né?

Só que, a partir aí de 1889 , um pesquisador começou a colocar um pouco mais de atenção no núcleo da célula. Os outros (?) cientistas não davam importância para o núcleo, achavam que não tinha muita função, né?

Mas esse pesquisador (inaudível) ele identificou em núcleos de glóbulos brancos um composto de natureza ácida, rico em fósforo, desprovido de enxofre e resistente à ação da pepsina, enzima que digere proteínas.

Convencido de que era uma nova substância que ele havia descoberto, que não era uma proteína, ele chamou, deu um nome de nucleína. Agora o que é que as informações aí da letra A, quais são as informações que permitiram ao pesquisador dizer: "olha, isso é uma nova substância, (inaudível), isso não é uma proteína"?

Que informações desse parágrafo que permitem a gente concluir que essa substância é diferente de proteína, que não é uma proteína?

A (inaudível)

A composição química e a resistência à pepsina. Então vamos primeiro analisar a resistência à ação da pepsina. O que é que é a pepsina?

Está aí nos parênteses.

Enzima que digere proteínas. Então, se eu pegar uma proteína e colocar em contato com a pepsina, o que é que vai acontecer com essa proteína? Vai ser digerida. O que significa isso?

Quebrada

Se eu colocar proteína perto, junto com a pepsina, o que é que vai acontecer com essa proteína? Vai ser digerida. O que é ser digerida?

É Ser quebrada. E o que é ser quebrada?

É ser quebrada em quê?

Em aminoácidos. Suas subunidades. Quais são as subunidades da proteína?

Aminoácidos, certo? Então se eu colocar lá uma proteína junto com pepsina, depois de um tempo, o que é que eu vou encontrar na preparação? Aminoácidos.

Tudo bem?

Certo? Aconteceu isso quando ele colocou essa nova substância junto com a pepsina?

Aconteceu isso?

Está escrito: "resistente à ação da pepsina". Então, essa substância foi quebrada em aminoácidos? A pepsina só age em proteínas. Isso aqui é uma proteína? Não?

Então isso é um ponto. Outro ponto que a Maria falou lá é a composição química. Composição química ácida, rica em fósforo. Proteína tem pouco fósforo, não tem fósforo. Tem nitrogênio, mas fósforo é pobre em fósforo. E essa substância tinha

\section{Fornecer}

evidências

Conferir

evidências

Conferir

evidências

Fornecer

evidências

Algum aluno responde? Algum aluno responde?

Algum aluno responde?

Algum aluno responde?

Conferir Algum aluno responde? evidências

Conferir evidências 
fósforo. Desprovida de enxofre e proteínas geralmente tem bastante (?) enxofre. Então também a composição química, os elementos químicos encontrados nessa substância são diferentes (?) das proteínas, mesmo assim, muitos pesquisadores não acreditaram nesse (inaudível) Richard. E falaram: "não, isso são proteínas que estão contaminadas com grupos fosfatos, né?" Certo?

Então acreditou, não se acreditou, né?

Nesses experimentos. Desconfiaram. E somente vinte anos depois com (inaudível) é que a natureza ácida do composto foi confirmada e realmente se estabeleceu que era uma substância nova, uma substância diferente. Nessa época ainda não se sabia a sua função, certo?

E chamou, como essa substância era uma substância ácida, chamou de ácido nucléico, certo? $\mathrm{Na}$ letra C. Outros experimentos ali entre (?) 1880 e 1900, verificou-se que esses ácidos nucléicos eles continham bases nitrogenadas, então lá o (inaudível) ele identificou que tem muito nitrogênio, né?

$\mathrm{Na}$ forma, aí, foi identificado de bases nitrogenadas.

Que bases nitrogenadas são essas?

Que bases nitrogenadas são essas?

Adenina, timina, citosina e guanina. São chamadas carinhosamente pela primeira letra do seu nome: $A, T, C, G$. Certo?

Tudo bem? Adenina, timina, citosina e guanina.

E carboidratos. Do tipo pentose. Então tem cinco carbonos ligados de maneira que forma aí, né?

Tridimensionalmente uma pentose, certo? Então nessa época se sabia mais ou menos isso. $E$, em 1900 foi (inaudível) a existência de dois tipos de ácidos nucléicos.

Então duas substâncias presentes no núcleo de natureza ácida, rica em fósforo, desprovido de enxofre e resistentes à ação da pepsina. O DNA e o RNA. Certo?

Ãh. Quais eram as características, diferenças entre esses dois ácidos nucléicos? A ribose, está escrito aí, né?

Forma o RNA. Então o açúcar, né?

A pentose aí que forma o RNA é a ribose. E além disso ele é formado por quatro bases nitrogenadas, mas essas quatro bases nitrogenadas são diferentes das bases do DNA. No RNA é adenina, uracila, citosina e guanina. Certo?

Então $A, U, C$ e G. E o carboidrato é a ribose.

No DNA, se verificou que o carboidrato se chama desoxirribose.

Por que esse nome? E uma ribose, "oxi" de oxigênio e "des" de sem.

Então na ribose que não tem um oxigênio, uma ribose com um oxigênio a menos. Por isso chamada
Valorar

posições

diferentes

Fornecer

evidências
A professora vai até a lousa enquanto fala $e$ escreve o título do texto e desenha a estrutura linear de uma pentose Ao fim da frase a professora vai à lousa e escreve: ácidos nucléicos Escreve DNA e RNA ao falar.

Escreve na lousa enquanto fala 
98

99

100

101

102

103

104

105

106

107

108

109

110

111

112

113

114

115

116

117

118

119

P

120

121

122

123

de desoxirribose. Certo?

E tem quatro bases nitrogenadas, mas quais bases

nitrogenadas? A, T, C e G. Adenina, adenina, timina, citosina e guanina. Então tem (inaudível), certo?

Então essas são duas diferenças desses ácidos nucléicos. (inaudível) o nome DNA e RNA.

Ácido, o DNA é ácido desoxirribo, por causa da ribose, nucleico porque era, está no núcleo. Sendo aqui o $A$ o $D$ e o N. Em português, qual seria a sigla? ADN, tá?

E é usada? Até é usada, só que acabou se fixando a sigla em inglês de que é deoxyribonucleic acid, certo?

Então, na verdade DNA é sigla do nome da substância em inglês que acabamos (inaudível), tá? E o RNA, ácido ribonucleico. Né?

$A, R, N$, certo?

Então R do RNA e D do DNA se referem ao açúcar que é desoxirribose e ribose, certo?

É uma das diferenças entre (inaudível), tá?

Então nessa época, 1900, se sabia mais ou menos do que era feito (inaudível), né?

Mas não se sabia como isso estava, isso estava ligado. Começa uma pista lá em 1912. Onde (inaudível) Jacobson (?) descobriram componente básico dos ácidos nucléicos eram uma estrutura composta por uma base nitrogenada ligada a uma pentose, ao carboidrato aqui que por sua vez estava unida a um grupo fosfato, tá?

Essa unidade foi chamada então de nucleotídeo. Nucleotídeo.

É. Se sabia que o ácido nucléico eram vários nucleotídeos ligados entre si. Como eles estavam ligados entre si ainda não se sabia nessa época (inaudível) tá?

Então isso é um nucleotídeo, Isso é uma subunidade básica do DNA e do RNA. Da mesma forma como a proteína tem sua subunidade básica. Que é qual? (inaudível)

A subunidade básica das proteínas?

Aminoácidos. Então vários aminoácidos ligados de uma determinada maneira formam uma proteína. Um carboidrato, que é um polissacarídeo tem sua subunidade básica que é chamada de? Monossacarídeo, tá?

Então vários monossacarídeos ligados de uma maneira que formam um polissacarídeo, um carboidrato.

Da mesma forma, DNA e RNA são macromoléculas, grandes moléculas formadas por uma subunidade. Qual é a subunidade do DNA e do RNA?

Nucleotídeo, que por sua vez, são formadas por: base nitrogenada, um carboidrato, que é chamado de pentose (inaudível) e um fosfato. Se esse carboidrato for a desoxirribose, é DNA ou RNA? DNA

DNA. Se for uma ribose?

RNA

RNA. Se essa base nitrogenada for uma adenina?

A professora escreve na lousa enquanto fala

Alguém respondeu?

Alguém respondeu, (inaudível) 


\begin{tabular}{lll}
\hline 124 & P & Pode ser um dos dois. Tem que ver aqui (inaudível) \\
125 & A & (inaudível) \\
126 & Isso. Se for um U? \\
127 & A & (inaudível) base nitrogenada é só (inaudível) \\
128 & P & No nucleotídeo tem uma só, tá? \\
129 & No DNA são vários nucleotídeos então eu tenho um \\
& nucleotídeo, por exemplo, DNA, a desoxirribose. Eu \\
& tenho um nucleotídeo que eu tenho aqui, um A, um \\
& outro nucleotídeo que tem T, timina, um outro \\
& nucleotídeo que tem C. E um outro nucleotídeo, \\
& que tem G. Tá? \\
& Então são quatro tipos de nucleotídeos diferentes \\
& para o DNA, assim como para, eu tenho 20 \\
& aminoácidos que se combinam de maneira \\
& diferentes para formar uma proteína que pode ter \\
& de 300 a 3000 aminoácidos, né? \\
& Eu tenho quatro nucleotídeos, na verdade são cinco \\
& nucleotídeos, na verdade são oito nucleotídeos. Eu \\
& tenho quatro nucleotídeos de DNA, (inaudível) \\
& desoxiribose, tenho A, T, C e o G. E quatro \\
& nucleotídeos de RNA com a ribose aqui e A, U, Ce \\
& G. Entenderam? \\
& Fala João.
\end{tabular}

Não, Se quando o açúcar, (inaudível)

Isso. Em todo nucleotídeo tem essa estrutura. Um grupo fosfato, um açúcar e uma base nitrogenada. Tem isso aqui.

(inaudível)

Pois é. É isso que a gente está determinando aqui, tá?

Em 1912 se chegou a isso. Como essa estrutura foi determinada, iremos lá para a página seguinte, que é o número três. (inaudível) Relacionar o DNA como sendo o material hereditário, tá?

O material genético, mas isso é uma outra coisa.

Vamos hoje discutir a estrutura do DNA. Nós vamos chegar lá na sua pergunta. No item três. Né?

Então de 1949 a 1953, então na primeira metade aí do século vinte, Erwin Chargaff quantificou as bases nitrogenadas em amostras de DNA de diferentes espécies e de diferentes órgãos de indivíduos da mesma espécie. (inaudível) a que conclusões interessantes ele chegou. Três conclusões.

Ele verificou que a composição de bases varia de espécie para espécie, então se eu pegar uma célula humana eu tenho um determinado número de bases nitrogenadas. Se eu pegar uma célula de um rato, eu tenho outro número de bases nitrogenadas. E assim por diante, certo? Então Então ele chegou nessa conclusão.
Outra conclusão que ele chegou, a proporção de bases é constante dentro da espécie. Então se eu pegar diferentes órgãos diferentes células, de vários indivíduos da mesma espécie, o número de bases é o mesmo. Então se eu pegar aí, de um indivíduo,
Considerado assim por entender que a professora coordena o que será dado nos diferentes momentos da aula
Fornecer

evidências

Fornecer evidências 
meu coração, meu olho, meu pé, a minha pele, meu estômago vai ter o mesmo número de bases nitrogenadas. Certo?

143

144

145

146

00:31:30 P

147

148

149

150

151

152

153

154

155

156

157

00:34:49 P
Fornecer

evidências

Escreve na lousa: uma das informações que permitiu (inaudível) chegarem à estrutura do DNA. Em qualquer espécie, a porcentagem de bases Adenina é igual a da timina e da citosina é igual à da guanina. Então eu tenho o total de bases daquela espécie, daquele órgão, ou daquela célula, né?

Eu tenho um total. Desse total eu tenho a mesma proporção entre A e T e a mesma proporção entre $C$ e G. Então isso foi um dado importantíssimo para que depois, na letra $C$, dois outros pesquisadores elaborassem o modelo do DNA.

Outra informação importante tem lá na letra B: Em 1951 (inaudível) e Rosalind Franklin, por difração de raios-X determinaram que o DNA possuía uma estrutura helicoidal. Então, não sei se vocês lembram quando a gente estava lá na exposição, é (...) logo depois que a gente saiu da célula, a gente entrou naquela parte escura e, o primeiro local onde a gente parou foi no modelinho de DNA, tinha a foto do Francis Creek do Watson. E tinha a foto de uma mulher e a fotografia de um raio- $X$, que ela tirou, mostrando a estrutura helicoidal do DNA (inaudível) de cima, mostrava que tinha uma estrutura helicoidal (inaudível) aqui no meio, né? Ãh, mostrando aí o formato dessa estrutura. Essa técnica da difração de raios-X é muito utilizada para identificar modelos, né?

Ver a forma das moléculas. É um (inaudível) indireto para eu verificar aí, modelos de estruturas químicas, tá?

Helicoidal é como se fosse uma hélice esticada. Então imagina uma escada caracol. Seria aí essa forma helicoidal, tá?

É (...) Essas informações permitiram que em 1953, somente 55 anos atrás, Watson e Creek elaborassem o modelo de DNA. Então o que eles postularam nesse modelo, né?

Então, já que era um modelo helicoidal, parecia que o DNA tinha duas cadeias. Duas cadeias de nucleotídeos. Ligadas pelas bases nitrogenadas. De maneira complementar. Sempre A se ligando com $T$, sempre $C$ se ligando com $G$. Dessa forma aqui. Tá?
Fornecer

evidências
Apaga a lousa enquanto fala
Ao fim da frase, desenha a representação da cadeia dupla do DNA Desenha na lousa mais um par de 
verdade, né? Eu vou ter isso daqui óh.

(inaudível)

A

(inaudível) sequência de bases, né?

Então, olha só. Eu tenho um nucleotídeo ligado no outro pelas bases nitrogenadas de maneira complementar: A com T, C com G. Isso tem que decorar, tá?

Daí, vocês podem decorar assim: Acontece com $\mathrm{G}$. O que acontece eu não sei, mas acontece com $\mathrm{G}$ (inaudível) pra decorar?

A com T, C com G, tá? Isso tem que decorar, O que acontece não sei, mas (inaudível)

É, além disso, você tem duas fitas de DNA. Ou duas hélices, digamos, porque é um modelo helicoidal. O fosfato de um nucleotídeo ligado com um carboidrato de outro nucleotídeo, formando uma fita aqui e uma outra fita aqui, certo? (inaudível)

$\mathrm{O} U$ está no RNA. Aqui a gente está falando do modelo de DNA. Depois a gente vai falar todas as diferenças entre DNA e RNA.

A (inaudível)

Aqui é T, aqui é DNA, Então (inaudível) se eu tenho nessa base nitrogenada $A$, que base nitrogenada vai ser aquil? $T$

T. Se eu tenho uma base nitrogenada que é o $C$ aqui, aqui eu tenho?

\section{G}

\section{G. Está certo?}

Ou G, C. A ordem não importa. Ou T, A também não importa, tá?

Pode inverter. Então veja, tenho essa (inaudível). Olhem só o modelo que Watson e Creek elaboraram. Duas fitas de DNA, que são complementares pelas bases nitrogenadas, Essas bases nitrogenadas se mantém unidas por ligações de hidrogênio, está escrito aí. Então A com T, tem duas ligações de hidrogênio e aqui tem três ligações de hidrogênio.

Vocês já aprenderam em química (...) Não

(...) esse tipo de ligação. Ãh. Outra coisa que eles também elaboraram, concluíram. As duas fitas, essa fita e essa fita são paralelas, certo? Só que elas estão na mesma direção? Não

Os carboidratos estão na mesma direção? Não. Estão vendo que a pontinha do pentágono está para lá? Pra cima e esse daqui pra baixo? Né? Então eles estão em direções opostas, por isso, que nucleotídeos

Fala baixo. Acho que responde à pergunta A professora fala rindo a ultima parte

Fala baixo, perto da câmera, inaudível para a professora.

Fala baixo, perto da câmera, inaudível para a professora. 
183

184

185

186

187

188

189

190

191

192

193

194

195

196

197

198

199

200

201

202

203

204

205

206

207
$00: 40: 21 \quad P$

foram chamadas de fitas antiparalelas. Certo?

Elas são paralelas, mas estão em direções opostas. E é conhecido então como modelo de dupla hélice (inaudível). Formando o DNA, certo?

Então agora a gente vai elaborar esse, todos nós, cada um, a gente vai elaborar um modelo de DNA com todas as personagens somos nós mesmos. Cada um é um nucleotídeo. Cada um será um nucleotídeo. Então nós seremos. O nosso corpo, né?

Vai ser o carboidrato, o braço, o braço esquerdo vai ser a base nitrogenada e a outra, o outro braço, a outra mão vai ser o grupo fosfato. Certo?

Então o braço esquerdo vai ligar base nitrogenada com base nitrogenada. O braço direito, fosfato, vai ligar com quem?

P Com o carboidrato do outro, certo?

Um nucleotídeo. Então você vai colocar a mão no fosfato do outro, tá?

Desculpa, no carboidrato do outro. Está certo?

(inaudível) tá? Então nós vamos fazer aqui no meio

óh.

00:39:34 Movimentação dos alunos na sala.

$P \quad$ A esquerda que é a base nitrogenada (inaudível) pessoas. Em que sentido tem que estar cada fita para que a mão esquerda seja a base nitrogenada e a mão direita seja o grupo fosfato?

00:40:05 P Em que sentido tem que estar cada fileira?

Vamos, gente, pra lá.

A mão esquerda é base nitrogenada, então (inaudível) tem que estar em que direção? As fileiras têm que estar em que direção?

Uma pra um lado e uma pro outro. A esquerda é base nitrogenada, então

(inaudível) você tem que estar em que direção? Isso.

Deve haver movimentação do aluno para a professora corresponder afirmativamente. com carboidratos.

Não (inaudível) você fica (inaudível) virada pra lá, certo?

Então você está com um fosfato solto, certo?

(inaudível) gente, aqui é uma mutação.

Vamos seguindo aqui então.

Fosfato ligado ao carboidrato.

E então vejam que cada (inaudível) com a mão, o fosfato solto, é, no final da fita a Maria marca a outra fileira (inaudível) pessoal.

Gente, esta é a molécula de DNA, certo? 


\begin{tabular}{|c|c|c|c|c|}
\hline 208 & & & $\begin{array}{l}\text { Isso aqui enrolado em proteína (inaudível) forma o } \\
\text { fio de DNA, a cromatina }\end{array}$ & \\
\hline 209 & & $A$ & (inaudível) & \\
\hline 210 & & $\mathrm{P}$ & Isso vai enrolar assim, né? & \\
\hline 211 & & & $\begin{array}{l}\text { Eu ensinei aula passada. Uma proteína aqui } \\
\text { (inaudível) }\end{array}$ & \\
\hline 212 & & $\mathrm{P}$ & $\begin{array}{l}\text { Se. Se, vejam. A gente já vai discutir, mas depois a } \\
\text { gente vai discutir mais. }\end{array}$ & \\
\hline 213 & & $\mathrm{P}$ & $\begin{array}{l}\text { Óh. Isso daqui óh, está sobrando o João, uma base } \\
\text { nitrogenada solta. Isso é uma mutação genética, tá? }\end{array}$ & \\
\hline 214 & & & Tem uma base a mais, certo? & \\
\hline 215 & & & $\begin{array}{l}\text { Ou se, por exemplo, então eu vou ligar aqui com o } \\
\text { João e vou fazer uma ligação certa. Se o João, o } \\
\text { João é A, ele é Adenina, certo? Então esse tem que } \\
\text { ser o que? }\end{array}$ & \\
\hline 216 & & $A$ & Adenina & Risadas \\
\hline 217 & & $A$ & $\mathrm{~T}$ & $\begin{array}{l}\text { Durante as risadas } \\
\text { alguém responde } \\
\text { rápido }\end{array}$ \\
\hline 218 & & $\mathrm{P}$ & Se ele é A, eu sou? T & \\
\hline 219 & & $A$ & $\mathrm{~T}$ & \\
\hline 220 & & $\mathrm{P}$ & $\begin{array}{l}\text { Certo? Se eu for um C, por exemplo, vou conseguir } \\
\text { me ligar aqui com o A? }\end{array}$ & \\
\hline 221 & & A & Não & \\
\hline 222 & & $\mathrm{P}$ & $\begin{array}{l}\text { Não. Ele não consegue ligar, então eu tenho outro } \\
\text { tipo também de mutação, tá? }\end{array}$ & \\
\hline 223 & & A & (inaudível) & \\
\hline 224 & & $\mathrm{P}$ & $\begin{array}{l}\text { Não. Pode ser. Se aqui é } A \text {, aqui pode ser T,A, pode } \\
\text { ser } G, C \text {, vai depender daquela molécula de DNA. } \\
\text { São quatro combinações aleatórias aqui, tá? }\end{array}$ & \\
\hline 225 & & & Tudo bem? Seus nucleotídeos? Podem sentar. & \\
\hline 226 & & & movimentam de volta ás carteiras. & \\
\hline 227 & & A & Professora (inaudível) & $\begin{array}{l}\text { Para a professora } \\
\text { no caminho de } \\
\text { volta para a } \\
\text { carteira para } \\
\text { perguntar }\end{array}$ \\
\hline 228 & & $\mathrm{P}$ & Essa estrutura (inaudível) Essa é a estrutura do DNA & \\
\hline 229 & & $A$ & $A \operatorname{com} T$ & \\
\hline 230 & & $\mathrm{P}$ & $\begin{array}{l}\text { A com T na base, mas não é só a base (inaudível). Tá } \\
\text { ligado com uma molécula de DNA }\end{array}$ & $\begin{array}{l}\text { Começam a voltar } \\
\text { passando entre as } \\
\text { carteiras. }\end{array}$ \\
\hline 231 & & $\mathrm{P}$ & É a gente vai (inaudível) & $\begin{array}{l}\text { Ainda } \\
\text { respondendo a } \\
\text { essa aluna }\end{array}$ \\
\hline 232 & $00: 44: 37$ & $\mathrm{P}$ & $\begin{array}{l}\text { Além de tudo isso, essa molécula está enrolada em } \\
\text { si mesma formando, imaginem uma escada caracol, } \\
\text { tá? }\end{array}$ & \\
\hline 233 & & & $\begin{array}{l}\text { Então, pois é, ficam os que estão (?) fora são os } \\
\text { carboidratos e os fosfatos e os degraus seriam as } \\
\text { bases nitrogenadas. }\end{array}$ & \\
\hline 234 & & A & (inaudível) & \\
\hline 235 & & $\mathrm{P}$ & Isso. Cada um desses seria um degrau. Aqui seriam & \\
\hline
\end{tabular}


236

237

238

239

240

241

00:45:45 P

242

243

00:45:59 P

244

245

246

247

248

249

250

251

00:48:00

252

253

254 os corrimões, né?

Eu vou mostrar depois em slide, né? Esses modelinhos (inaudível) são as bases nitrogenadas. Isso. As bases, né?

A gente vai fazer. A gente vai montar o modelinho. A gente vai ver no PowerPoint, as representações, então a gente vê isso daí.

Na outra sala deu tempo de fazer só isso.

Então a gente vai poder aí discutir o item dois.

Experimentos que relacionam o DNA como sendo o material genético. Tá?

Então estrutura do DNA determinada vou parar (?)

e daí volto para o item dois, na página 1, tá?

É. Olhem o que está escrito aí embaixo. Nessa época, por volta do início do século XX, as proteínas eram as melhores candidatas para conterem as informações genéticas, por sua impressionante variabilidade de composição, estrutura e função. Lembra que eu falei pra vocês?

As proteínas estavam em todos os lugares das células, compondo várias estruturas, participando de várias reações químicas, então, por que não elas serem também as portadoras das informações hereditárias? Né?

Das informações passadas de uma geração para a outra.

$P \quad$ Só que ãh, começaram-se a fazer alguns experimentos, né?

Para se estudar, aí, um tipo de pneumonia causada por uma bactéria que levaram a uma conclusão diferente.

Então, número 1, aí identificação do material hereditário em bactérias. Então é um experimentozinho que foi feito, né?

Que levou a algumas conclusões. Então, sabia-se nessa época, mais ou menos aí 1920, que numa linhagem de bactérias Streptococcus pneumoniae existiam duas variedade da bactéria, duas linhagens. Uma que causa pneumo(...) uma que tem uma cápsula externa e causa pneumonia. Então é o que está escrito aí. Bactérias que causam pneumonia, o nome da espécie é esse: Streptococcus pneumoniae.

P A linhagem S produz uma cápsula de carboidrato e a linhagem $R$, não produz cápsula de carboidratos e não causa pneumonia em camundongos. Em 1928, o que é que esse Frederick Griffith fez?

Ele pegou e (inaudível). (inaudível) Seguinte experimento. Ele pegou, é (...) matou as linhagens $S$, as bactérias da linhagem $S$ pelo calor. Ele pegou um monte de bactérias (inaudível) mortas, certo?

E aí, o que é que ele fez? Ele inoculou lá, fez algumas amostras, né?

E inoculou alguns tipos de bactéria, em camundongos, tá? Esses são (inaudível) Não parece?
Fornecer

evidências
Burburinho e comentários dos alunos sobre os desenhos da professora
Não referentes ao tema da aula, não entram nas classificações 


\begin{tabular}{|c|c|c|c|}
\hline 256 & $\mathrm{P}$ & Olhem com os olhos (inaudível) & \\
\hline 257 & A & Professora, você fazia um ratinho mais bonito & \\
\hline 258 & A & É verdade & \\
\hline 259 & A & Acho que piorou & \\
\hline 260 & $\mathrm{P}$ & $\begin{array}{l}\text { Mas o que é que ele fez? Ele pegou aqui e inoculou } \\
\text { nos ratinhos ele inoculou bactérias S vivas, o que é } \\
\text { que aconteceu com o ratinho? }\end{array}$ & $\begin{array}{l}\text { Conferir } \\
\text { evidências }\end{array}$ \\
\hline 261 & A & Morreu & \\
\hline 262 & $\mathrm{P}$ & Morreu & \\
\hline 263 & A & Morreu & \\
\hline 264 & $\mathrm{P}$ & Certo? Pegou pneumonia e morreu & $\begin{array}{l}\text { Fornecer } \\
\text { evidências }\end{array}$ \\
\hline 265 & $P$ & $\begin{array}{l}\text { Aí ele pegou e inoculou com } \mathrm{R} \text { vivas (inaudível), } \\
\text { certo? O que é que aconteceu com o ratinho? }\end{array}$ & $\begin{array}{l}\text { Conferir } \\
\text { evidências }\end{array}$ \\
\hline 266 & A & Nada & \\
\hline 267 & A & Sobreviveu & \\
\hline 268 & $\mathrm{P}$ & Sobreviveu, né? Feliz da vida e não teve pneumonia & $\begin{array}{l}\text { Fornecer } \\
\text { evidências }\end{array}$ \\
\hline 269 & A & (inaudível) & \\
\hline 270 & $\mathrm{P}$ & $\begin{array}{l}\text { A S e a R têm essa diferença estrutural. Uma produz } \\
\text { uma cápsula, né? }\end{array}$ & \\
\hline 271 & & $\begin{array}{l}\text { Então a bactéria tem uma parede aí na cápsula } \\
\text { maior de carboidratos. Então bactérias } \\
\text { encapsuladas é mais difícil as células do sistema } \\
\text { imunológico destruir, então por isso ela causa a } \\
\text { doença, causa pneumonia. Essa bactéria R, ela só } \\
\text { tem lá a membrana, né? }\end{array}$ & $\begin{array}{l}\text { Fornecer } \\
\text { evidências }\end{array}$ \\
\hline 272 & & $\begin{array}{l}\text { Então ela fica mais fácil das células destruírem, } \\
\text { fagocitarem e tal e aí então não causa pneumonia. } \\
\text { O próprio corpo já combate. }\end{array}$ & $\begin{array}{l}\text { Fornecer } \\
\text { evidências }\end{array}$ \\
\hline 273 & $A$ & Professora (inaudível) & \\
\hline 274 & $\mathrm{P}$ & $\begin{array}{l}\text { Não, essa daqui. Essa cápsula de carboidratos (?) } \\
\text { Então essa característica estrutural faz com que ela. } \\
\text { Faz com que ela cause ou não cause pneumonia, } \\
\text { tá? }\end{array}$ & $\begin{array}{l}\text { Conferir } \\
\text { evidências }\end{array}$ \\
\hline 275 & & $\begin{array}{l}\text { Porque ela pode sobreviver (inaudível) né? Então, o } \\
\text { que é que aconteceu? }\end{array}$ & \\
\hline 276 & $\mathrm{P}$ & $\begin{array}{l}\text { Em ratinhos as } S \text { causam pneumonia ou matam } \\
\text { logo. As } R \text { não causam pneumonia e morrem. Aí o } \\
\text { que é que ele fez? }\end{array}$ & $\begin{array}{l}\text { Fornecer } \\
\text { evidências }\end{array}$ \\
\hline 277 & & $\begin{array}{l}\text { Ele colocou as } \mathrm{S} \text { mortas pelo calor, certo? O que é } \\
\text { que aconteceu com o ratinho? }\end{array}$ & $\begin{array}{l}\text { Conferir } \\
\text { evidências }\end{array}$ \\
\hline 278 & $\mathrm{P}$ & $\begin{array}{l}\text { Não teve a pneumonia e sobreviveu, certo? Só que, } \\
\text { o que é que ele fez? }\end{array}$ & $\begin{array}{l}\text { Fornecer } \\
\text { evidências }\end{array}$ \\
\hline 279 & & $\begin{array}{l}\text { Ele pegou, juntou. Colocou as } \mathrm{S} \text { mortas mais as } \mathrm{R} \\
\text { vivas. E aí, o que aconteceu com o ratinho? O } \\
\text { camundongo morreu (?) }\end{array}$ & $\begin{array}{l}\text { Conferir } \\
\text { evidências }\end{array}$ \\
\hline 280 & $\mathrm{P}$ & $\begin{array}{l}\text { Só que, era o resultado esperado? Se a } \mathrm{S} \text { com } \mathrm{S} \\
\text { morta vive, com } \mathrm{R} \text { viva, vive. }\end{array}$ & $\begin{array}{l}\text { Conferir } \\
\text { evidências }\end{array}$ \\
\hline 281 & & Então, qual seria o resultado? & $\begin{array}{l}\text { Conferir } \\
\text { evidências }\end{array}$ \\
\hline 282 & A & Viver. & \\
\hline 283 & $P$ & Viver, não pegar pneumonia e viver, certo? & \\
\hline 284 & & $\begin{array}{l}\text { Então teve que explicar esse resultado não } \\
\text { esperado. Qual que seria uma hipótese dele? }\end{array}$ & \\
\hline 285 & & Que a S morta ressuscitou? Né? & \\
\hline 286 & & $\begin{array}{l}\text { E aí causou a pneumonia no ratinho? Não era uma } \\
\text { hipótese muito plausível, né? }\end{array}$ & \\
\hline 287 & & $\begin{array}{l}\text { Então ele teve que criar uma outra hipótese. Qual } \\
\text { foi a hipótese dele? }\end{array}$ & \\
\hline
\end{tabular}


288

289

290

291

292

00:53:17 P

293

294

295
Que as $R$ vivas pegavam alguma coisa das $S$ mortas e se transformavam em $S$ viva. Né?

Então as R que estavam vivas se transformavam em $\mathrm{S}$ vivas. Certo?

Pegavam alguma coisa dessas daqui. Está lá, né?

Alguma coisa dela está lá, apesar dela estar morta. Essa pega, ela está viva, pegou alguma coisa dela e se transformou em S. Então ele deu um nome para esse princípio de transformação bacteriana.

As $\mathrm{R}$ vivas se transformaram em $\mathrm{S}$. Certo?

Transformação bacteriana. Só que, aí, o que é que aconteceu? Em mil novecentos (...), ele não sabia explicar porque e qual era esse princípio transformante que estava lá na bactéria $\mathrm{S}$ morta que continua a ter sua ação. É captado, né? É absorvido pela R e a R se transforma em S, né? Então ele não sabia o que é que era esse princípio transformante, mas em mil novecentos (...) e os experimentos continuaram. Está com dúvida, João? Pode falar.

A Eu estava pensando por que é que ele não fez experimento com a R viva, com a R morta?

Porque a $\mathrm{R}$ morta já causa, a $\mathrm{R}$ viva, ela já não causa pneumonia, né?

Então morta

Então morta, também não vai causar pneumonia. Então, na verdade, qual, o problema aqui é que a $S$ morta sozinha causou um resultado, a $R$ viva sozinha causou o mesmo resultado, a sobrevivência do rato. Só que quando as duas eram colocadas juntas, o resultado era diferente. Como é, como é que se explica isso? Tá?

A R morta também ia ter esse mesmo resultado, né?

Então ele levantou essa hipótese, mas ele não sabia como explicar essa hipótese e esse princípio.

Anos depois, em 1944, outro pesquisador, o Avery, ãh (...) verificou que essa transformação bacteriana também ocorria in vitro. Não precisava do camundongo pra ocorrer. Então se ele pegasse o tubo de ensaio, colocasse bactérias $\mathrm{S}$ mortas e juntasse ali bactérias $\mathrm{R}$ vivas, depois analisasse, ele veria que naquele tubo de ensaio, o que aconteceu?

Apareceriam bactérias S vivas, certo?

Então também se confirmou aí, se verificou que esse experimento aparecia bactérias vivas. E aí no laboratório desse pesquisador, o que é que ele verificou?

Se eu colocasse então, num tubo de ensaio, né?

Apareciam essas bactérias $S$ vivas. Se eu colocasse álcool aqui, alguma coisa se separava aqui, se formava um precipitado espesso que tinha (?) o princípio transformante. Como ele sabia que era o princípio transformante. Como ele sabia que era o princípio transformante?

Então formava um precipitado, né?
Conferir evidências

Fornecer

evidências

Fornecer evidências Fornecer evidências 
Então separava alguma coisa do líquido e precipitado. E ele pegasse e colocasse só isso junto com $R$ vivas, o que é que acontecia com essa $R$ viva? Óh, formou essas bactérias $S$ vivas ali no tubo de ensaio. Ele colocou álcool nesse tubo de ensaio. 0 que é que aconteceu?

Formou um precipitado, Separou coisa, então formou um líquido e o precipitado.

A (inaudível) Aí, pera aí, isso aí o que é que ele fez?

O líquido e o precipitado. Então tinha duas coisas ali. $O$ que é que eles fizeram? Eles pegaram esse líquido e juntaram com as bactérias $R$. Juntaram o precipitado com as bactérias $R$. Em qual dos dois tubos houve a transformação da bactéria $\mathrm{R}$ em $\mathrm{S}$ ?

Na que tinha o líquido, ou na que tinha o precipitado?

A Precipitado

Na que tinha precipitado, tudo bem? Então o princípio transformante, que causa a transformação da bactéria, está no líquido ou no precipitado? No precipitado.

No precipitado, ok?

Um passo. Outro passo: ainda em 1949. O que é que eles fizeram então?

Ah, então está no precipitado. Eles conseguiram isolar grandes quantidades aí desse precipitado e foram testando pra ver de fato o que era esse precipitado. Foram testando, testando, testando, misturando esse precipitado com várias coisas. Então, com o que é que eles misturaram esse precipitado?

Pegaram esse precipitado e misturaram com amilase. $\mathrm{O}$ que é que faz a amilase?

(inaudivel)

A

Digere. "ase" é de enzima que digere alguma coisa. Né? O quê?

(inaudível)

A

Amido, tá? Então a amilase é a enzima que transforma o amido em?

Transforma o amido em?

Carboidrato.

Ele é?

O Amido é o quê? Ele é um polissacarídeo

A Monossacarídeo.

$P \quad$ A amilase vai?

A (inaudivel)

P Em monossacarídeos. Ali, ou em dissacarídeos, tá?

Então vai digerir o amido nas subunidades menores. Se o precipitado for amido, o que e que vai acontecer com esse precipitado?

refere ao precipitado.

Fala baixo. Provavelmente a professora não escutou.

Conferir evidências Ele vai continuar com o princípio transformante? Depois do contato com a amilase? 


\begin{tabular}{|c|c|c|c|}
\hline 338 & $P$ & Por quê? & \\
\hline 339 & A & A amilase (inaudível) & \\
\hline 340 & $P$ & $\begin{array}{l}\text { Porque a amilase vai digerir, isso significa dizer o } \\
\text { quê? }\end{array}$ & \\
\hline 341 & & $\begin{array}{l}\text { Que a amilase vai destruir o amido. Então, se for } \\
\text { amido. Se quando eu pegar esse princípio e juntar } \\
\text { com bactérias R, a bactéria R vai se transformar em } \\
\text { S? }\end{array}$ & $\begin{array}{l}\text { Enfatizar } \\
\text { justificativa }\end{array}$ \\
\hline 342 & & Se for amido? & \\
\hline 343 & $A$ & Não & \\
\hline 344 & $P$ & $\begin{array}{l}\text { Mas o que é que ele fez? Ele colocou a amilase, } \\
\text { colocou na bactéria R, só que a bactéria R se } \\
\text { transformou em S. É amido? }\end{array}$ & $\begin{array}{l}\text { Fornecer } \\
\text { evidências }\end{array}$ \\
\hline 345 & $P$ & Não. Entenderam a lógica? & \\
\hline 346 & & Entenderam os passos? & \\
\hline 347 & & Tudo bem? & \\
\hline 348 & & O que é que ele fez? Então não é amido. & \\
\hline 349 & $\mathrm{P}$ & $\begin{array}{l}\text { Depois ele colocou proteases. Proteases são } \\
\text { enzimas que digerem o quê? }\end{array}$ & \\
\hline 350 & A & Proteína (inaudível) & \\
\hline 351 & $\mathrm{P}$ & Proteína. São enzimas que digerem proteína. & \\
\hline 352 & $P$ & $\begin{array}{l}\text { Pepsina é um tipo de enzima, que digere proteína. } \\
\text { Tem várias, que são chamadas genericamente de } \\
\text { proteases, tá? }\end{array}$ & \\
\hline 353 & & $\begin{array}{l}\text { É (...) continuou com o princípio transformante, ou } \\
\text { seja, se eu pegar isso daqui, juntas com bactérias R } \\
\text { elas vão se transformar em S. São proteínas? }\end{array}$ & $\begin{array}{l}\text { Fornecer } \\
\text { evidências }\end{array}$ \\
\hline 354 & $P$ & $\begin{array}{l}\text { Não. Se ele colocou lá num outro tubo de ensaio, } \\
\text { um outro princípio transformante com } \\
\text { ribonucleases. Ribonucleases digerem o que? }\end{array}$ & \\
\hline 355 & $A$ & Ribossomo & \\
\hline 356 & $\mathrm{P}$ & $\begin{array}{l}\text { RNA, na verdade. Ribossomo ele tem essa palavra } \\
\text { porque ele é formado também por RNA, tá? }\end{array}$ & \\
\hline 357 & & $\begin{array}{l}\text { Ribonuclease digere ribose, quem é formado por } \\
\text { ribose é o RNA, tá? Ãh (...) Juntou com bactérias R, } \\
\text { essas R se transformaram em S. É RNA? }\end{array}$ & $\begin{array}{l}\text { Fornecer } \\
\text { evidências }\end{array}$ \\
\hline 358 & A & Não & \\
\hline 359 & $P$ & Não & \\
\hline 360 & $P$ & $\begin{array}{l}\text { Colocou o princípio transformante com } \\
\text { desoxirribose. Desoxirribonucleases. } \\
\text { Desoxirribonucleases são enzimas que digerem? }\end{array}$ & \\
\hline 361 & $P$ & $\begin{array}{l}\text { DNA, certo? Então quebram e cortam o DNA. Pegou } \\
\text { esse princípio agora, colocou com bactérias R. O } \\
\text { que é que aconteceu? }\end{array}$ & $\begin{array}{l}\text { Fornecer } \\
\text { evidências }\end{array}$ \\
\hline 362 & & Elas continuaram $\mathrm{R}$. & \\
\hline 363 & A & "Caraca". Tudo pra chegar nisso. & \\
\hline 364 & $P$ & Tudo pra chegar nisso. É o quê? & \\
\hline 365 & & O que é que era o princípio transformante? & \\
\hline 366 & A & (inaudível) & \\
\hline 367 & $P$ & DNA, certo? & \\
\hline 368 & & $\begin{array}{l}\text { Então, a substância transformante é o DNA. Agora, } \\
\text { ãh (...) eu quero que vocês me respondam a } \\
\text { seguinte pergunta. Para a próxima aula. Tá, então } \\
\text { vejam gente. Uma coisa específica, um experimento } \\
\text { específico que, de transformação bacteriana. Que } \\
\text { mostrou que o princípio transformante, que faz } \\
\text { transformar bactérias R em S é o DNA. Por que é } \\
\text { que isso foi um experimento que demonstra que o } \\
\text { DNA é o material que contém as informações } \\
\text { hereditárias? }\end{array}$ & $\begin{array}{l}\text { Incitar } \\
\text { justificativa }\end{array}$ \\
\hline
\end{tabular}




\begin{tabular}{|c|c|c|c|}
\hline 369 & A & (inaudível) morta & \\
\hline 370 & $P$ & Mas por quê? & \\
\hline 371 & & $\begin{array}{l}\text { Por que é que a informação hereditária tem haver } \\
\text { com esse experimento todo? Né? }\end{array}$ & \\
\hline 372 & & $\begin{array}{l}\text { Por que é que ãh (...) a ideia do DNA ser o princípio } \\
\text { transformante é uma ideia que levou os } \\
\text { pesquisadores a pensarem que o DNA contém a } \\
\text { informação hereditária? }\end{array}$ & \\
\hline 373 & & $\begin{array}{l}\text { Não é nem o RNA, não é nem a proteína, não é nem } \\
\text { o amido. Vocês percebem que uma coisa não } \\
\text { necessariamente está tão diretamente relacionada. } \\
\text { Vocês tem que pensar no experimento, todo } \\
\text { experimento. Ãh (...) no que esse DNA representa } \\
\text { pra essa bactéria, né? }\end{array}$ & \\
\hline 374 & & $\begin{array}{l}\text { Para responder essa questão, certo? Entenderam } \\
\text { (inaudível) a questão? }\end{array}$ & \\
\hline 375 & A & Não & \\
\hline 376 & $\mathrm{P}$ & $\begin{array}{l}\text { Então vamos elaborar. Por que o experimento, por } \\
\text { que as conclusões do experimento da } \\
\text { transformação bacteriana, quais são as conclusões? }\end{array}$ & \\
\hline 377 & & $\begin{array}{l}\text { Que o DNA é o princípio transformante, permite } \\
\text { afirmar que o DNA é o portador das informações } \\
\text { hereditárias? }\end{array}$ & \\
\hline 378 & $\mathrm{P}$ & Né? Porque é um experimento específico, né? & \\
\hline 379 & & $\begin{array}{l}\text { Lembra lá da aula, do texto, da discussão da célula, } \\
\text { é um experimento específico que permite depois } \\
\text { uma generalização. O DNA é portador das } \\
\text { informações genéticas. Por quê? }\end{array}$ & \\
\hline 380 & & $\begin{array}{l}\text { O que é que esse experimento mostra aí, né? Para } \\
\text { se chegar nessa ideia, nessa hipótese. }\end{array}$ & \\
\hline 381 & A & Professora, é pra entregar? Professora? & \\
\hline 382 & $\mathrm{P}$ & É, nós vamos discutir, mas é pra entregar. & \\
\hline 383 & $\mathrm{P}$ & $\begin{array}{l}\text { Ok? Tragam essa ficha pra gente terminar o } \\
\text { segundo experimento. }\end{array}$ & $\begin{array}{l}\text { O sinal bate no } \\
\text { meio da frase da } \\
\text { professora. Os } \\
\text { alunos começam a } \\
\text { se levantar para } \\
\text { sair }\end{array}$ \\
\hline
\end{tabular}

Aula 7I - 23/04/2008 - $3^{\circ}$ ano I

\begin{tabular}{|c|c|c|c|c|c|}
\hline Linha & Tempo & Pessoa & Falas & $\begin{array}{l}\text { Ações pró- } \\
\text { argumentação }\end{array}$ & Observações \\
\hline 1 & 0:00:00 & 0 & & & $\begin{array}{l}\text { Pessoas se } \\
\text { ajeitam nas } \\
\text { carteiras, } \\
\text { professora } \\
\text { prepara coisas. }\end{array}$ \\
\hline 2 & 0:01:19 & $\mathrm{P}$ & Pessoal, vamos fazer a chamada? & & Faz a chamada \\
\hline 3 & $0: 02: 27$ & $\mathrm{P}$ & Pessoal! & & \\
\hline 4 & 0:03:12 & $\mathrm{P}$ & Pessoal! Peguem a ficha, peguem a tarefa & & \\
\hline 5 & $0: 03: 27$ & A & Professora. & & \\
\hline 6 & $0: 03: 47$ & $\mathrm{P}$ & É $(\ldots)$ & & \\
\hline
\end{tabular}




\begin{tabular}{|c|c|c|c|c|}
\hline 7 & $0: 03: 49$ & $P$ & $\begin{array}{l}\text { É porque eu estou elaborando como fazer a melhor } \\
\text { pergunta para vocês e da melhor maneira possível, } \\
\text { certo? }\end{array}$ & \\
\hline 8 & & & $\begin{array}{l}\text { É (...) Então, por isso algumas modificações no } \\
\text { percurso do processo. É. Então, o que é que a gente } \\
\text { vai fazer hoje? Eu quero retomar os textos (?) Nós } \\
\text { utilizamos (?) aí no item dois porque que o DNA é o } \\
\text { material hereditário em bactérias. Quero explicar o } \\
\text { item dois, né? }\end{array}$ & \\
\hline 9 & & & $\begin{array}{l}\text { Porque que é o material hereditário em vírus. E aí } \\
\text { nós vamos reelaborar esta questão, discutir em } \\
\text { pequenos grupos, a partir do que vocês já } \\
\text { trouxeram de casa, certo? }\end{array}$ & \\
\hline 10 & & & $\begin{array}{l}\text { E aí fazer, elaborar um outro texto a partir de uma } \\
\text { nova questão mais ampla, tudo bem? }\end{array}$ & \\
\hline 11 & $0: 04: 48$ & $\mathrm{P}$ & $\begin{array}{l}\text { Então a tarefa de casa vai servir aí como subsídio } \\
\text { para a elaboração, a discussão do grupo, tá bom? }\end{array}$ & \\
\hline 12 & $0: 04: 59$ & A & Eu tinha feito & \\
\hline 13 & $0: 05: 03$ & $P$ & Isso, isso mudou. É... & \\
\hline 14 & 0:05:10 & $\mathrm{P}$ & Vocês vão argumentar (?) tá? & \\
\hline 15 & & & $\begin{array}{l}\text { Mas de qualquer maneira vamos para o item dois. } \\
\text { Então vocês lembram que a estrutura do DNA né? }\end{array}$ & \\
\hline 16 & & & Então o DNA formado lá por nucleotídeos, né? & \\
\hline 17 & & & $\begin{array}{l}\text { Lembram o que são os nucleotídeos, só pra gente ir } \\
\text { guardando, memorizando a estrutura do DNA, né? } \\
\text { Então, eu tenho lá. }\end{array}$ & \\
\hline 18 & 0:05:45 & $\mathrm{P}$ & $\begin{array}{l}\text { Isto daqui é um nucleotídeo, que é a subunidade } \\
\text { DO DNA (?). Deixa eu começar que nem eu comecei } \\
\text { na outra aula. Estamos onde? }\end{array}$ & \\
\hline 19 & & & $\begin{array}{l}\text { Estamos na célula, vamos para o núcleo da célula. } \\
\text { No núcleo da célula, o que é que eu tenho? }\end{array}$ & \\
\hline 20 & 0:06:05 & A & DNA & \\
\hline 21 & 0:06:07 & $P$ & Em que forma? & \\
\hline 22 & & A & Cromatina & \\
\hline 23 & 0:06:10 & $\mathrm{P}$ & $\begin{array}{l}\text { Como a cromatina ou o cromossomo. O que é que é } \\
\text { a cromatina ou o cromossomo? }\end{array}$ & \\
\hline 24 & $0: 06: 17$ & A & Vários falam juntos - não da pra entender & \\
\hline 25 & 0:06:18 & $P$ & Fios, né? & \\
\hline 26 & & & $\begin{array}{l}\text { Um fio de DNA enrolado em proteínas. Sendo que a } \\
\text { cromatina é o DNA um pouquinho mais esticado. E } \\
\text { em que fase do ciclo celular é chamado de } \\
\text { cromatina? }\end{array}$ & \\
\hline 27 & & $A$ & Não dá pra entender & \\
\hline 28 & 0:06:39 & $P$ & Fases & \\
\hline 29 & & $A$ & G1 & \\
\hline 30 & $0: 06: 40$ & $P$ & G1, S e G2, certo? & $\begin{array}{l}\text { Parece que algum } \\
\text { aluno também } \\
\text { está falando... }\end{array}$ \\
\hline
\end{tabular}




\begin{tabular}{|c|c|c|c|}
\hline 31 & & & $\begin{array}{l}\text { Isso. Que é, são fases do ciclo de vida das células } \\
\text { (muito barulho), tá? }\end{array}$ \\
\hline 32 & $0: 06: 56$ & $P$ & $\begin{array}{l}\text { Então em cada uma dessas fases acontece uma } \\
\text { coisa. No G1 a célula faz as suas funções, na fase S } \\
\text { ocorre a duplicação do DNA, No G2 ela continua } \\
\text { exercendo suas funções. Até que depois ela se } \\
\text { divide, ocorre a divisão celular, tá? }\end{array}$ \\
\hline 33 & & & (inaudível), chamado de mitose, certo? \\
\hline 34 & 0:07:26 & $P$ & $\begin{array}{l}\text { Na divisão celular esses fios de DNA são chamados } \\
\text { de, eles se enrolam mais ainda, se compactam mais } \\
\text { ainda e são chamados de? }\end{array}$ \\
\hline 35 & & A & Cromossomos \\
\hline 36 & $0: 07: 38$ & $P$ & Cromossomos, certo? \\
\hline 37 & 0:07:42 & $\mathrm{P}$ & $\begin{array}{l}\text { E aí a gente foi mais a fundo nesse modelo (...) } \\
\text { químico para verificar a estrutura desse DNA. A } \\
\text { estrutura química dessa PONTINHA (?) Desse } \\
\text { cromossomo, certo? }\end{array}$ \\
\hline 38 & & & $\begin{array}{l}\text { E vimos que isso é formado por DNA. E o DNA é } \\
\text { formado pelo quê? }\end{array}$ \\
\hline 39 & & A & (Inaudível) \\
\hline 40 & 0:08:07 & $\mathrm{P}$ & $\begin{array}{l}\text { Por nucleotídeos. E os nucleotídeos por sua vez são } \\
\text { formados por (...) um grupo fosfato, um açúcar, né? }\end{array}$ \\
\hline 41 & & & $\begin{array}{l}\text { Um carboidrato e uma base nitrogenada. No caso } \\
\text { do DNA, que forma o (inaudível), cromossomo. } 0 \\
\text { açúcar é qual? }\end{array}$ \\
\hline 42 & & & Qual é o nome desse açúcar? \\
\hline
\end{tabular}

43

Que é o que dá o nome de DNA.

45

Desoxirribose, certo?

É o nome do açúcar do DNA. Se for RNA terá outro (ácido nucléico?), qual o nome do açúcar?

Ribose. Então, na célula existem dois tipos de ácidos nucléicos. O DNA e o RNA. Os dois são formados por nucleotídeos. Só que no núcleo das células, fios de DNA são formados somente por DNA. Existe RNA no núcleo e no citoplasma, fazendo lá suas funções (inaudível), tá? Mas o fio de DNA chamado de cromatina ou cromossomo só é formado por DNA, tá? E qual é a estrutura do DNA? Existem cinco bases nitrogenadas. Quais são as quatro bases do DNA? Adenina, que é o $A$, timina que é o $t$, citosina, que é o c e guanina que é o g. São as bases 
55

Do RNA?

57

G, C, A e U. Onde ficava o t, fica o U, certo?

59

60

0:11:06

$P$

61

62

63

64
Então tem um U no lugar do T. Então é A, U, C e G.

Como é que o DNA se liga?

Ele se liga, né?

A gente fez lá, lembram?

A gente fez lá (inaudível). O carboidrato de um se liga no fosfato do outro. Então é aqui. O fosfato de um se liga no carboidrato do outro, certo?

Formando uma fita de DNA. Além disso há uma outra (inaudível) de DNA, onde as bases nitrogenadas se ligam, por ligações de hidrogênio, certo?

Por qual regra? Se aqui for $A$, aqui vai ser T. Se aqui for $C$, aqui vai ser $G$. Então $A$ sempre liga com $T$ e $C$ sempre liga com $G$. A com $T$, no DNA, A com T tem duas ligações de hidrogênio, $C$ com $G$ três ligações de hidrogênio. $G$ é guanina. É, são bases nitrogenadas

Percebem que esses nomes: adenina, timina, guanina, uracila, citosina, tá?

É...mas são abreviados no DNA pela primeira letra, tá?

Então são as duas fitas de DNA, né?

Ligadas no seu interior pelas bases nitrogenadas. Pela regra A com T, C com G. Tudo bem? Só (inaudível)

Uma diferença, uma outra diferença entre o DNA e o RNA. O DNA é (inaudível), enquanto o RNA é uma fita única.

A Inaudível

P É. Vai ter. No caso do DNA é (inaudível), só que (inaudível). De acordo com a função que ele exerce (inaudível) Essas são as diferenças estruturais.

Bom, e nós vimos na aula passada no experimento citado aí no item 2.1 da ficha que, a partir de bactérias que causam pneumonia em camundongos, nós tínhamos a transformação de bactérias $\mathrm{R}$, lembram? Bactérias que não causam pneumonia em bactérias $\mathrm{S}$, bactérias que causam pneumonia, certo? E essa transformação dessas bactérias (inaudível) qual é a estrutura química que causa (inaudível). São as proteínas?
Não

São, é o próprio DNA, certo?
Os alunos falam completando a fala da professora. 
78

79

0:14:41

80

81

82

83

84

85

86

0:16:16

87

Então o DNA causa a transformação bacteriana, transformando bactérias que eram de um tipo em bactérias que eram de outro tipo.

Além disso, foi feito um outro experimento. (inaudível) vírus bacteriófagos. O que são vírus bacteriófagos?

Bacteriófago é o nome do vírus. Vírus bacteriófagos são aqueles que atacam bactérias. Então bactérias também são atacadas por vírus, tá?

Não são só os seres humanos e (inaudível). Bactérias também são atacadas por vírus. Vocês devem ter visto isso no ano passado (inaudível) ciências, o modo de funcionamento dos vírus. E eles discutiram, ao mesmo tempo que discutiram o modo de funcionamento dos vírus, eles discutiram o que é que entra na bactéria, como é esse modo de funcionamento para que o vírus faça a destruição da bactéria.

E o que é que isso tem haver com o DNA? (inaudível) item 2.

Então, aqui está uma célula da bactéria.

Aqui o vírus bacteriófago, que tem mais ou menos esse formato

Sabe-se que o vírus, que a estrutura do vírus é muito simples, certo?

(inaudível) vírus bacteriófago. É um vírus que ataca bactéria. Fago tem haver com alimentação (inaudível)

Ele realmente tem esse formato. É, várias fotografias em microscópio eletrônico mostraram um formato parecido com esse. Estabeleceu esse modelo. E aí o que acontece?

Qual o modo de ação do vírus?

O vírus ele infecta (?) A célula (inaudível) e aí dentro da célula, o vírus, ele não tem nada. Ele não tem outras enzimas tem outras enzimas, proteínas, ele não tem citoplasma (inaudível) nada, nada.

Ele tem apenas essa cápsula proteica, uma cápsula de proteínas, e ele tem DNA no seu interior.

Existem vírus de RNA também, mas esse vírus bacteriófago ele é um vírus de DNA, certo? Tanto é que é uma estrutura tão simples que há uma discussão se ele é um ser vivo ou não. Porque se a gente considerar que o vírus é um ser vivo, que ele é formado de célula (inaudível) ter enzimas, que realizam reações químicas. $O$ vírus não tem nada disso. (inaudível) pode ser considerado um ser vivo ou não. Mas isso é uma outra discussão. De qualquer maneira ele se reproduz. E ele usa...

Pois é, se essa for a definição de ser vivo, né? 
se é vivo ou não.

98

99

$0: 18: 57$

(Inaudivel) De qualquer maneira aqui, a gente pode conversar depois, mas, é (...) Ele não tem nada disso, mas ele usa toda a estrutura da célula para se reproduzir.

Então as enzimas das células (inaudível), todas (inaudível), ele usa todas as ferramentas celulares de uma outra célula (inaudível), dentro dessa célula, produzir outros indivíduos, centenas de indivíduos, né? Idênticos a ele mesmo.

101

102

Até que ele tenha se reproduzido (inaudível) a célula explode liberando esses outros vírus que vão infectar outras células (inaudível) infecção

Tem. Tem alguns antivirais, tá?

Mas eles são muito caros e muito específicos no caso do ser humano, né?

Então normalmente o que é que acontece numa gripe, num (inaudível), num resfriado, causados por vírus?

(inaudível) Antibióticos. Antibiótico é pra matar bactérias.

Enquanto seu sistema imunológico está lá atacando um monte de vírus (inaudível) você está fraco (inaudível) bactérias oportunistas também se instalam e acabam também se reproduzindo, né? Só que (inaudível) bactérias, pro seu corpo ter mais condições de acabar com (inaudível) tá?

O vírus ele se reproduz dentro da célula. Ou da bactéria, no caso dessa espécie de vírus, ou, por exemplo, se for um vírus do resfriado ou da gripe, vai se reproduzir nas células do sistema respiratório. Se for o vírus da AIDS vai se reproduzir nas células do sistema imunológico, então cada vírus ele é específico de uma célula. Esse daqui, de bactérias.

Então ele se reproduz dentro da célula utilizando o material celular para se reproduzir. E a pergunta que eles fizeram foi qual?

$\mathrm{Na}$ época havia a questão: qual é o material hereditário?

Responsável pelas informações genéticas e hereditárias, DNA ou proteína? Né?

Eles acreditavam inclusive que eram as proteínas (inaudível) Fazem parte de todas as reações químicas, né?

Existem aí milhares de proteínas, cada uma com uma função específica, mas imensa variabilidade de forma e função. Por que não seriam as proteínas as que contém(?) o material hereditário ou material genético

Aí fizeram o experimento (inaudível) as bactérias (inaudível) 1944. Em 1952 (inaudível) do vírus. Como o vírus ele é formado só de DNA ou proteína (inaudível) será que entra tudo, será que entra uma parte do vírus na bactéria. E aí, quem é responsável por produzir novos vírus?
Enfatizar

justificativa 
116

117

118

119

120

121

122

123

124

125

A

126

127

128

129

130

131

132

133

134

A

135

136

A
Então o que eles fizeram?

Eles marcaram com substâncias radioativas a proteína e o DNA do vírus. Por que é que eles marcaram com substâncias radioativas? As substâncias radioativas emitem radioatividade e isso pode ser detectado, né?

Com o uso da tecnologia. É como se emitissem luz e você identificasse pra onde vai aquela substância, certo? (inaudível) fotografar isso.

Então, eles marcaram. O DNA tem fósforo, certo?

Tem lá um grupo fosfato. Então eles marcaram o DNA com fósforo radioativo.

E marcaram a proteína. Proteína tem enxofre. E eles marcaram a proteína com enxofre radioativo. E aí eles colocaram esses vírus marcados em contato com as bactérias e o que é que eles registraram?

Que entrou o quê?

O que eles encontraram na bactéria, fósforo radioativo ou enxofre radioativo?

Fosforo radioativo.

(inaudível) encontrar na bactéria somente fósforo radioativo e fora da bactéria, enxofre radioativo. (inaudível) na bactéria é o DNA viral, certo? Então o DNA viral e a partir das (inaudível) no DNA é que o vírus constrói um monte de vírus, certo? Então esse experimento junto com o outro (inaudível) levaram à conclusão de que o DNA é o portador das informações hereditárias. Então, vocês vão explicar isso. (inaudível) e eu vou colocar a seguinte questão na lousa.

Porque uma coisa gente é(...) eu tenho a seguinte afirmação: o DNA é portador das informações hereditárias, certo?

Como é que se chegou a essa afirmação?

Como é que esses experimentos contribuíram para chegar a essa afirmação (inaudível)

Esse experimento (inaudível) item 2.a. em 1952, Alfred Hershey e Martha Chase, marcaram o DNA do vírus com enxofre radioativo e as proteínas com enxofre, ne?

Verificaram que apenas o DNA do vírus penetra na bactéria, produzindo em 30 minutos centenas de outros vírus completos, tá?

Pois é. (inaudível) infecção por vírus ela é bastante drástica. Ela é muito rápida. De uma célula você produz centenas, essas centenas vão CONTAMINAR(?) Outra célula, então é uma... Muito rápido

Pode ser, mas por quê? 


\begin{tabular}{|c|c|c|c|c|c|}
\hline \multicolumn{3}{|l|}{138} & \multicolumn{3}{|l|}{$\begin{array}{l}\text { (inaudível) conseguem se reproduzir (inaudível)seu } \\
\text { corpo (inaudível) Aí o que é que aconteceu? }\end{array}$} \\
\hline \multicolumn{3}{|l|}{139} & \multicolumn{3}{|l|}{$\begin{array}{l}\text { Seu corpo está fraco, o sistema imunológico baixo } \\
\text { (inaudível) se reproduzir pra ter a morte (inaudível) } \\
\text { no mesmo estado saudável novamente (inaudível). } \\
\text { Então outras bactérias (inaudível) conseguem se } \\
\text { alojar ali, certo? }\end{array}$} \\
\hline \multicolumn{3}{|l|}{140} & \multicolumn{3}{|l|}{$\begin{array}{l}\text { É mais fácil. E o seu corpo não consegue combater. } \\
\text { (inaudível) }\end{array}$} \\
\hline \multicolumn{6}{|l|}{141} \\
\hline 142 & & & \multicolumn{3}{|l|}{ Então a questão é } \\
\hline \multicolumn{3}{|l|}{143} & \multicolumn{3}{|l|}{$\begin{array}{l}\text { Tá? Então agora vocês vão ter um tempo para se } \\
\text { reunir em quatro pessoas, discutir essa questão. } \\
\text { Vocês já pensaram sobre isso em casa ao fazer o } \\
\text { exercício que era só de um experimento. Agora } \\
\text { vocês vão reelaborar isso, utilizando os dois } \\
\text { experimentos. }\end{array}$} \\
\hline \multicolumn{3}{|l|}{144} & \multicolumn{3}{|l|}{$\begin{array}{l}\text { Daí vocês vão fazer a discussão (inaudível) } \\
\text { individual, tá? }\end{array}$} \\
\hline 145 & & $A$ & \multicolumn{3}{|l|}{ Professora (inaudível) } \\
\hline 146 & & $P$ & \multicolumn{3}{|l|}{ Vocês terão(inaudível) } \\
\hline 147 & & & \multicolumn{3}{|l|}{$\begin{array}{l}\text { Não, vocês vão fazer a discussão, aí depois cada um } \\
\text { vai fazer o seu (inaudível) individualmente }\end{array}$} \\
\hline 148 & $0: 31: 15$ & Geral & & & $\begin{array}{l}\text { Os alunos } \\
\text { começam a se } \\
\text { movimentar para } \\
\text { formar grupos. }\end{array}$ \\
\hline \multicolumn{6}{|c|}{ Aula 81 - 28/04/2010 - 3의 } \\
\hline Linha & Tempo & Pessoa & Falas & $\begin{array}{l}\text { Ações pró- } \\
\text { argumentação }\end{array}$ & Observações \\
\hline 1 & & & Pessoal! & & \\
\hline 2 & & & Pessoal! & & \\
\hline 3 & & & ah, & & \\
\hline 4 & & & na aula passada a gente & & \\
\hline 5 & & & discutissem então o por que & & \\
\hline 6 & & & vamos lá meninos & & \\
\hline 7 & & & Vocês terminaram a aula passada então & & \\
\hline 8 & & & shhhh & & \\
\hline 9 & & & Vocês terminaram a aula passada & & \\
\hline 10 & & & shhhh & & \\
\hline 11 & & & $\begin{array}{l}\text { a questão de porque que o DNA é o portador das } \\
\text { informações hereditárias. }\end{array}$ & & \\
\hline 12 & & & inaudível certo? & & \\
\hline 13 & & & e daí eu quero começar, & & \\
\hline 14 & & & $\begin{array}{l}\text { Por que é que o DNA é o portador das informações } \\
\text { hereditárias }\end{array}$ & & \\
\hline 15 & 00:00:00 & $\mathrm{P}$ & $\begin{array}{l}\text { (...) dos experimentos das bactérias permitiram aos } \\
\text { pesquisadores afirmarem isso, afirmarem que o DNA é o } \\
\text { portador das informações hereditárias, por quê? }\end{array}$ & & $\begin{array}{l}\text { o áudio } \\
\text { começa no } \\
\text { meio dessa } \\
\text { frase. }\end{array}$ \\
\hline 16 & & A & (inaudível) & & \\
\hline
\end{tabular}




\begin{tabular}{|c|c|c|c|c|}
\hline 17 & 00:00:20 & $\mathrm{P}$ & $\begin{array}{l}\text { se vocês quiserem reformular as suas respostas a partir da } \\
\text { discussão. Você quer ler sua questão? Pode ler. A Maria } \\
\text { vai ler. }\end{array}$ & $\begin{array}{l}\text { Encorajar a } \\
\text { ouvir }\end{array}$ \\
\hline 18 & 00:00:37 & A & Pode? & \\
\hline 19 & 00:00:38 & $\mathrm{P}$ & $\begin{array}{l}\text { Ainda não. A gente está esperando o silêncio da classe } \\
\text { para a Maria poder ler. }\end{array}$ & \\
\hline 20 & 00:00:45 & A & $\begin{array}{l}\text { Podemos afirmar que o DNA é o portador das informações } \\
\text { hereditárias porque no primeiro experimento quando foi } \\
\text { colocada a bactéria que causava a doença morta e a que } \\
\text { não causava viva, esperava-se que o ratinho não morrese. } \\
\text { mas as informações hereditárias da bactéria morta passou } \\
\text { para a outra da bactéria. Assim o DNA foi modificado e } \\
\text { (inaudível)igual ao da bactéria mãe. No segundo } \\
\text { experimento concluiu-se que o DNA é portador das } \\
\text { informações pois encontraram fósforo radioativo dentro } \\
\text { da bactéria, sendo que ele havia sido colocado antes no } \\
\text { DNA do vírus. O vírus se reproduziu e matou a bactéria. } \\
\text { Observa-se que em ambas as situações foi por meio do } \\
\text { DNA que houve as mudanças, concluindo que as } \\
\text { informações (inaudível). }\end{array}$ & \\
\hline 21 & 00:01:35 & $\mathrm{P}$ & $\begin{array}{l}\text { Tá. Então vamos analisar sua resposta. Você descreve o } \\
\text { primeiro experimento e explica as suas conclusões. Você } \\
\text { descreve o segundo experimento e explica suas } \\
\text { conclusões. Aí depois no final você faz uma generalização } \\
\text { disso, tentando explicar porque. Qual é a natureza das } \\
\text { mudanças do processo que você explica aí. Você começa a } \\
\text { sua explicação, você fala aí, bom então se houve mudança } \\
\text { no DNA isso mostra que ah (...) mostra que o DNA é o } \\
\text { portador das informações hereditérias. Que mudanças são } \\
\text { essas? }\end{array}$ & \\
\hline 22 & 00:02:15 & $\mathrm{P}$ & Que mudanças são essas? Que mudanças são essas? & \\
\hline 23 & $00: 02: 25$ & A & $\begin{array}{l}\text { No caso do experimento a bactéria que não causava a } \\
\text { doença passou a causar. }\end{array}$ & \\
\hline 24 & 00:02:30 & $\mathrm{P}$ & $\begin{array}{l}\text { Ela passou a causar a doença, tá? Vocês estão sempre se } \\
\text { refereindo, nesse experimento principalmente, à bactéria } \\
\text { no singular. }\end{array}$ & \\
\hline 25 & $00: 02: 40$ & A & As bactérias & \\
\hline 26 & 00:02:43 & $\mathrm{P}$ & $\begin{array}{l}\text { Pra causar a doença, né? Uma bactéria é o suficiente pra } \\
\text { causar a doença? }\end{array}$ & \\
\hline 27 & 00:02:49 & $A$ & Não. & \\
\hline 28 & 00:02:50 & $\mathrm{P}$ & $\begin{array}{l}\text { Não, né? Então, o que é que aconteceu? Quando é (...) a } \\
\text { bactéria foi colocada lá, a bactéria que não causa a doença } \\
\text { foi colocada junto com a bactéria que causa doença, mas } \\
\text { que estava morta. Né? O que é que houve aí? A bactéria } \\
\text { conseguiu pegar o que dessa bactéria morta? }\end{array}$ & \\
\hline 29 & 00:03:15 & $A$ & A capacidade de causar doença. & \\
\hline 30 & 00:03:18 & $\mathrm{P}$ & $\begin{array}{l}\text { A capacidade de causar doença. Aonde estava essa } \\
\text { capacidade? }\end{array}$ & \\
\hline 31 & 00:03:22 & A & No DNA & \\
\hline 32 & 00:03:23 & $\mathrm{P}$ & $\begin{array}{l}\text { No DNA, porque eles separaram lá o princípio } \\
\text { transformante e viram que esse princípio era feito de DNA. } \\
\text { Então as bactérias, elas tem essa capacidade, são os únicos } \\
\text { seres vivos que têm essa capacidade, então aquelas que } \\
\text { estão no meio de um monte de bactérias, essa que tem a } \\
\text { capacidade de pegar o DNA de outra bactéria, não é? Nós } \\
\text { não (...) }\end{array}$ & \\
\hline 33 & 00:03:48 & $\mathrm{P}$ & $\begin{array}{l}\text { É. É uma geração horizontal que a gente chama. Na } \\
\text { mesma geração. A gente tem essa capacidade? }\end{array}$ & \\
\hline 34 & 00:03:54 & $\mathrm{P}$ & $\begin{array}{l}\text { Não. As informções elas passam de que maneira no ser } \\
\text { humano, de um ser humano pro outro? }\end{array}$ & \\
\hline
\end{tabular}




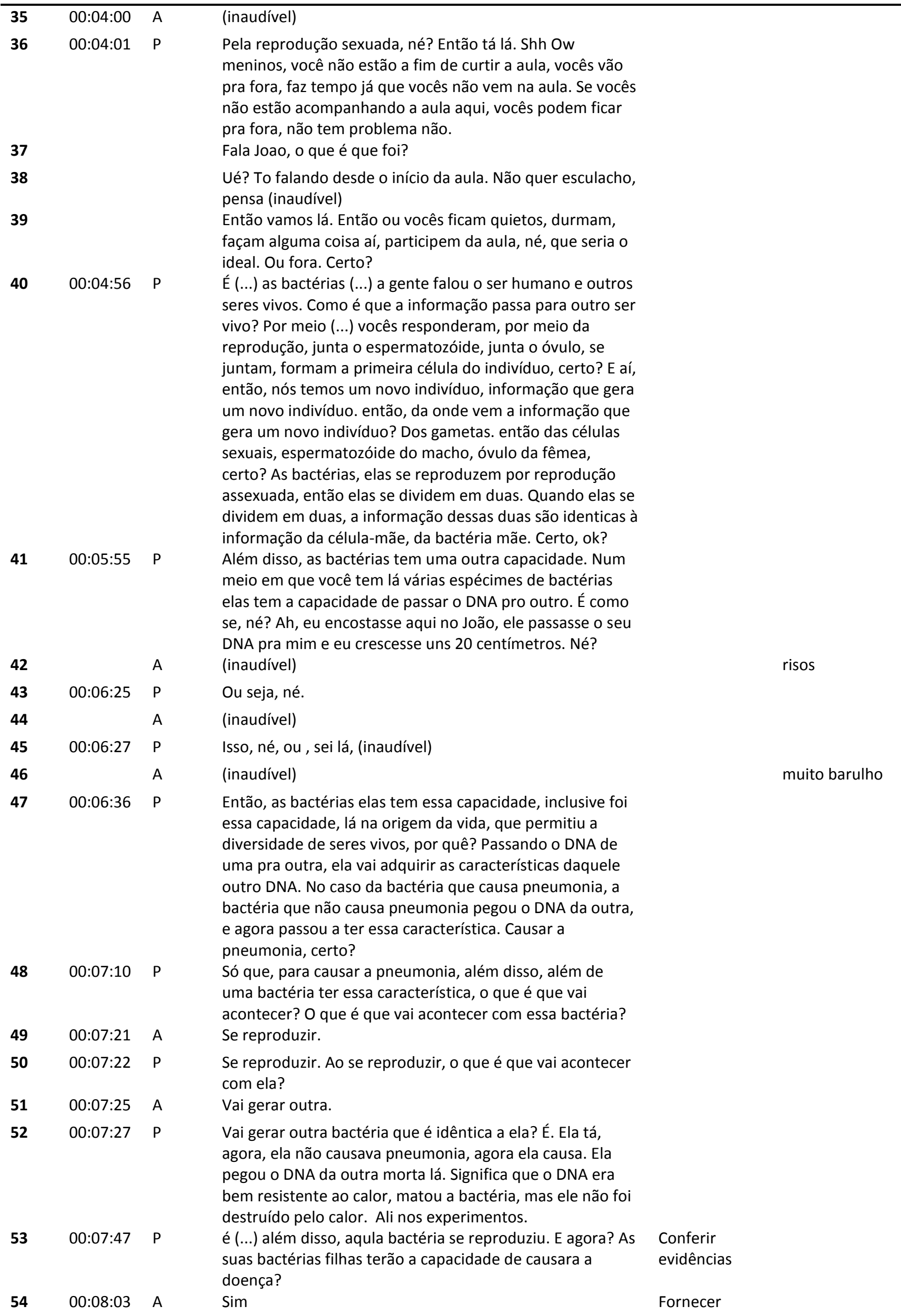




$\begin{array}{lll}\mathbf{5 5} & 00: 08: 05 & \mathrm{P} \\ \mathbf{5 6} & 00: 08: 08 & \mathrm{P} \\ \mathbf{5 7} & 00: 08: 09 & \mathrm{~A} \\ \mathbf{5 8} & 00: 08: 17 & \mathrm{P} \\ \mathbf{5 9} & 00: 08: 32 & \mathrm{~A} \\ & & \\ \mathbf{6 0} & 00: 09: 12 & \mathrm{P} \\ & & \\ & & \\ & & \\ & & \\ & & \\ \mathbf{6 1} & 00: 09: 57 & \mathrm{P} \\ \mathbf{6 2} & 00: 10: 09 & \mathrm{P} \\ \mathbf{6 3} & 00: 10: 13 & \mathrm{P} \\ \mathbf{6 4} & 00: 10: 21 & \mathrm{P}\end{array}$

Certo?

Então, fala

(inaudível) genéticas que a bactéria

não, bactéria não. Bactéria tem DNA. Virus, tem vírus de DNA ou RNA, mas esse vírus, desse experimento é de DNA imaginado que as duas bactérias tivessem vivas, (inaudível) porque vc vai dizer que (inaudível) essa capacidade da bactéria (inaudível)

algumas tem essa capacidade, algumas (inaudível) então tem as bactérias doadoras e tem as bactérias receptoras de DNA, tá? Tem aquela bactéria viva e tem aquela bactéria como a do experimento lá que tem a capacidade de (inaudível) uma bactéria morta, né? Então isso vai depender da espécie de bactéria. Não é toda bactéria (inaudível) que tem essa capacidade. ALgumas tem outras não, algumas (inaudível) elas formasm (inaudível) pode sair. Os quatro. Pode sair rápido.

Eu avisei

Você tem lá a bactéria, certo?

você tem lá o DNA da bactéria. Você tem lá uma outra bactéria elas tem, elas formam uma ponte (inaudível) de proteína em que o DNA de uma vai passar pra outra. (inaudível) pode. Né?

(inaudível)

Então. É que a bactéria, ela tem duas formas de DNA. Ela tem um DNA circular pequenininho, chamado de plasmídeo. E ela tem um outro DNA que é o grande cromossomo (inaudível) circular também (inaudível) é, normalmente o DNA que elas passam, elas não passam todo o DNA também, elas passam esse plasmídeo, que é um DNA circular pequenininho. Esse plasmídeo é (inaudível) das bactérias. no caso das bactérias que causam a doença, qual era a característica que permitia a ela causar a pneumonia?

Lembram?

É uma característica física dela, que era uma capsula aqui, né, de carboidrato e conferiu uma maior resistência a essa bactéria, certo? Então essa daqui, que estava nesse DNA, nesse plasmídeo, ela (inaudível) o DNA ficou la. Essa bactéria conseguiu captar esse DNA e aí, o que é que aconteceu? Teve as características determinadas por aquele plasmídeo. Essa cápsula de carboidrato.

Exatamente

(inaudível) continuou com o DNA dela, só que esse DNA aqui consegue dar outras características pra ela, então ela ganhou mais características, que características ela ganhou?

Um cápsula, que fez com que ela sobrevivesse no corpo do rato,e aí então causasse pneumonia

Aí, qual era a informação importante aí, então, na verdade, ela adquiriu uma estrutura, que foi o DNA, descobriram que foi o DNA pelos experimentos. Esse DNA o que é que ele fez? Duas coisas ele fez. Ele fez uma coisa que a Maria colocou ali, ele provocou mudanças na própria bactéria, certo? Então ele determina a característica Física da bactéria? sim, né? Então isso é uma das conclusões que a gente pode tirar, o DNA ele está associado com as características físicas ali da própria 
bactéria.

73

00:13:40 P

74

00:13:57 P

75

00:14:29 A

76

00:14:30 P

77

00:14:34 P

78

00:14:48 P

79

00:14:50 P

80

00:15:19 P

81

00:15:28 P

82

00:15:30 P

83

00:15:37 A

84

00:15:51 A

85

00:15:52

86

00:16:20 A

87

00:16:30 P

88

89

00:16:39 A

00:16:41 P

90

00:16:45 A

91

00:17:10 P

92

00:17:11 A

93

94

95

96

00:19:38 A
Que outra coisa aconteceu. Se suas filhas, suas filhas estão

lá. Na hora que ela se reproduziu, ela vai ter as mesmas características da mãe. Com o novo DNA?

Sim. Por que é que eu posso concluir que é com o novo DNA? Porque, não causou a pneumonia? E pra causar a pneumonia eu tenho que ter muitas bactérias. Daquele mesmo tipo, certo? Então o que é que eu posso admitir? Que, na reprodução, essas bactérias pegaram também aquele DNA, certo? Se pegaram DNA que conferiu as mesmas características da mãe, então quem tem a informação que passa de uma geração pra outra?

\section{O DNA.}

é o DNA, né?

já dá pra concluir que é o DNA. Assim como no caso do vírus. O que é que o experimento mostrou? Quem entra na célula e tem a informação para construir novos vírus? O DNA.

Tem informação para construir novos vírus. Então constrói novo vírus idênticos ao anterior. A mesma coisa aqui. E aí é só o DNA, ele separou o DNA da proteína. Então é só o DNA que contém essa informação pra construir novos indivíduos que tenham a mesma característica que o indivíduo que gerou. Certo? Então passa essa informação pelo DNA. Tudo bem?

Mais alguém quer ler a resposta? Vocês querem reformular?

Sim,

é, ou reformular, ou passara a limpo. Então, vamos fazer agora para entregar?

Professora, você pode ler a minha?

Professora, é individual?

É individual.

Professora, as duas informações lá sobre abactéria. Uma é a formação a partir do DNA, que (inaudível). Certo? E a segunda foi qual?

(inaudivel)

Ah, então foi por isso que (...) entendi. Tá.

Que é a ideia do vírus, lá. (inaudível) DNA inteiro e construiu novos vírus, né? (inaudível) indivíduo, com as informações de cada indivíduo.

Ah entendi.

Dez minutos?

Dez minutos

or que aqui é uma nova fórmula (inaudível) entrou na

célula causou a doença

Tem mais a ver com isso

Bia deixa eu ler sua resposta?

Ah, tenho que marcar prova.
Fornecer

evidências
A partir daqui os diálogos são particulares. volta a ser

geral a

conversa 


\begin{tabular}{|c|c|c|c|c|}
\hline 97 & & A & (inaudível) & \\
\hline 98 & $00: 21: 36$ & $\mathrm{P}$ & é, final de trimestre. & \\
\hline 99 & & $\mathrm{P}$ & (inaudível) & \\
\hline 100 & & A & (inaudível) & $\begin{array}{l}\text { muito barulho } \\
\text { generalizado }\end{array}$ \\
\hline 101 & $00: 22: 17$ & & Tem três trabalhos pra entregar dia 5 & \\
\hline 102 & $00: 22: 19$ & & Tá, mas é pra entregar, não? & \\
\hline 103 & & & É, mas tem que fazer & \\
\hline 104 & & $\mathrm{P}$ & é, dia sete, pode ser. & \\
\hline 105 & & $A$ & Dia sete tá longe. & \\
\hline 106 & & $\mathrm{P}$ & $\begin{array}{l}\text { Tem que entregar as notas na outra semana, então não } \\
\text { tem jeito, ou é dia cinco ou é dia sete. }\end{array}$ & \\
\hline 107 & $00: 22: 41$ & A & (inaudível) & $\begin{array}{l}\text { muita agitação } \\
\text { na sala }\end{array}$ \\
\hline 108 & & A & Vai cair o que professora? & \\
\hline 109 & $00: 22: 08$ & $\mathrm{P}$ & Tudo. & \\
\hline 110 & 00:22:09 & $\mathrm{P}$ & Não. Estou brincando. & \\
\hline 111 & & & Posso até fazer & \\
\hline 112 & & & É (...) não vai cair osmose, difusão e transporte, está bom? & \\
\hline 113 & $00: 23: 24$ & & Vai cair o quê? & \\
\hline 114 & $00: 23: 25$ & & Essa parte de DNA & \\
\hline 115 & & & $\begin{array}{l}\text { Desde o texto "a descoberta da célula", lembram do texto } \\
\text { que a gente viu? }\end{array}$ & \\
\hline 116 & & & Vocês vão ver tudo no final do semestre & \\
\hline 117 & & & $\begin{array}{l}\text { A descoberta da célula, depois, estrutura de DNA e por } \\
\text { que é que o DNA é o material hereditário. Diferença entre } \\
\text { DNA e RNA, né? Que tem a ver com a estrutura do DNA. Se } \\
\text { quiserem eu ponho na lousa. }\end{array}$ & \\
\hline 118 & $00: 23: 59$ & A & Pode por. & \\
\hline 119 & $00: 26: 45$ & $\mathrm{P}$ & $\begin{array}{l}\text { É isso o que cai na prova: a descoberta da célula, depois a } \\
\text { estrutura química do DNA e do RNA, organização do DNA } \\
\text { SHHH, organização do DNA no núcleo da célula, então, } \\
\text { cromatina, cromossomo, que a gente aprendeu. Shhh. Sua } \\
\text { relação com o ciclo celular. G1, S, G2, mitose. Cariótipo e } \\
\text { doenças cromossômicas, DNA como material hereditário. } \\
\text { Prova feita (inaudível), tá? }\end{array}$ & \\
\hline 120 & $00: 27: 26$ & $\mathrm{P}$ & Pra eu ler, ou pra entregar? & \\
\hline 121 & $00: 26: 27$ & $A$ & Pra entregar & \\
\hline 122 & $00: 27: 35$ & $\mathrm{P}$ & Pronto, podem entregar? & \\
\hline 123 & $00: 27: 36$ & $A$ & Não. & \\
\hline 124 & $00: 27: 36$ & $A$ & Calma aí. & \\
\hline 125 & & $P$ & Então dia sete é quarta feira que vem, né? & \\
\hline 126 & 00:28:09 & $\mathrm{P}$ & $\begin{array}{l}\text { Até lá vai dar tempo de estudar a replicação do DNA, mas } \\
\text { acho que eu não vou colocar na prova. }\end{array}$ & \\
\hline 127 & $00: 28: 37$ & $P$ & Pronto gente? Vamos continuar? & \\
\hline 128 & $00: 31: 52$ & $\mathrm{P}$ & $\begin{array}{l}\text { Pronto? Vamos lá? Se vocês estudarem, bem para } \\
\text { (inaudível) vocês tem que estudar, né? Mas na segunda } \\
\text { feira, (inaudível) antes da prova, tá? Pronto, todos } \\
\text { entregaram? }\end{array}$ & \\
\hline 129 & $00: 34: 52$ & $\mathrm{P}$ & Pessoal, vamos lá. Continuando aqui. & \\
\hline \multirow[t]{2}{*}{130} & $00: 34: 58$ & $\mathrm{P}$ & João, apaga a luz, por favor? & \\
\hline & & & FIM DO TRECHO DE INTERESSE. & \\
\hline
\end{tabular}




\section{Apêndice 03 - Transcrição de aula $3^{\circ}$ II}

\begin{tabular}{|c|c|c|c|c|c|}
\hline Linha & Tempo & Pessoa & Fala & $\begin{array}{l}\text { Ações pró- } \\
\text { argumentação }\end{array}$ & Observações \\
\hline 1 & 00:00:00 & $P$ & Ah! Então vamos mudar de ideia porque é pra nota! & & \\
\hline 2 & 00:00:02 & $P$ & Não, né! & & $\begin{array}{l}\text { Alunos se } \\
\text { levantam } \\
\text { para } \\
\text { entregar os } \\
\text { exercícios }\end{array}$ \\
\hline 3 & 00:00:27 & $P$ & Mais alguém fez? (...) Indecifrável & & $\begin{array}{l}\text { Levanta os } \\
\text { olhos para a } \\
\text { sala }\end{array}$ \\
\hline 4 & 00:00:36 & $P$ & Oh! (...) Pessoal! (...) Vamos lá? & & \\
\hline 5 & 00:00:40 & $P$ & $\begin{array}{l}\text { O primeiro, na verdade eu concordo que talvez tenha } \\
\text { sido uma das dúvidas. }\end{array}$ & & \\
\hline 6 & 00:00:48 & $P$ & $\begin{array}{l}\text { O primeiro cromossomo ele já veio como exemplo de } \\
\text { onde colar (...) só que, naquela outra ficha que vocês } \\
\text { tinham que recortar, tinha também o cromossomo } \\
\text { número } 1 . \text { Tá? }\end{array}$ & & $\begin{array}{l}\text { Mostra um } \\
\text { pedaço } \\
\text { específico da } \\
\text { folha de } \\
\text { exercícios }\end{array}$ \\
\hline 7 & 00:00:58 & $P$ & $\begin{array}{l}\text { Então, na verdade, aquele cromossomo } 1 \text { ou era pra } \\
\text { colar em cima ou era para descartar. Tá? Então essa era } \\
\text { uma das coisas, está certo? Ele só colocou aqui como } \\
\text { exemplo de onde era pra colar. Por quê? }\end{array}$ & & \\
\hline 8 & 00:01:09 & $P$ & $\begin{array}{l}\text { Como que era a organização aqui do cariótipo que vocês } \\
\text { fizeram? Vocês leram aí as instruções. }\end{array}$ & & \\
\hline 9 & $00: 01: 14$ & $P$ & $\begin{array}{l}\text { Você tinha que recortar, colocar o centrômero na linha } \\
\text { tracejada, né? }\end{array}$ & & \\
\hline 10 & 00:01:20 & $A$ & É (...) então. & & \\
\hline 11 & $00: 01: 21$ & $P$ & E sempre $(\ldots)$ & & \\
\hline 12 & $00: 01: 22$ & A & Indecifrável & & \\
\hline 13 & 00:01:23 & $P$ & $\begin{array}{l}\text { É, e aí os pares, né? De acordo com a numeração (...) e } \\
\text { sempre quando está mais cinzinha, né? Mais cinza, você } \\
\text { tinha que colocar a parte cinza para baixo, aí. }\end{array}$ & & $\begin{array}{l}\text { Mostra um } \\
\text { pedaço } \\
\text { específico da } \\
\text { folha de } \\
\text { exercícios }\end{array}$ \\
\hline 14 & 00:01:36 & $P$ & Então essa seria a orientação dos cromossomos. & & \\
\hline 15 & 00:01:40 & $P$ & $\begin{array}{l}\text { E depois ele foi explicando em cada item, então isso } \\
\text { eram onze instruções, né? Qual (...) ele dava as } \\
\text { instruções para você identificar qual era o cromossomo } \\
\text { de cada par, né? }\end{array}$ & & \\
\hline 16 & 00:01:52 & $P$ & $\begin{array}{l}\text { E aí, se tivesse alguma coisa sobrando, como a Maria } \\
\text { falou: "tem um monte sobrando". Se tivesse um } \\
\text { sobrando, já estou te falando que na verdade era só (...) } \\
\text { para (...) não era problema o número } 1 .\end{array}$ & & $\begin{array}{l}\text { Mostra um } \\
\text { pedaço } \\
\text { específico da } \\
\text { folha de } \\
\text { exercícios }\end{array}$ \\
\hline 17 & 00:02:05 & A & Tá, mas sobrou (indecifrável), entendeu? & & \\
\hline 18 & 00:02:07 & $P$ & Âh... & & \\
\hline 19 & 00:02:08 & A & Eu cortei só os da folha & & \\
\hline 20 & 00:02:11 & $P$ & Mas, sobrando, sobrando mesmo, (indecifrável) & & $\begin{array}{l}\text { Fala junto } \\
\text { com a aluna }\end{array}$ \\
\hline 21 & 00:02:11 & A & Indecifrável & & $\begin{array}{l}\text { Fala junto } \\
\text { com a } \\
\text { professora }\end{array}$ \\
\hline 22 & 00:02:16 & $P$ & Então! Dois X. Dois X e um Y? & & \\
\hline 23 & $00: 02: 20$ & $A$ & É! & & Alguns \\
\hline
\end{tabular}


alunos falam junto, ajudando na resposta da professora para a aluna

Então, que doença é essa que a gente viu?

Aquela lá do (...) Klinefelter

Klinefelter! Síndrome de Kleinefelter. Então um dos cariótipos era Síndrome de Klinefelter. Tinha dois $\mathrm{X}$ e um $Y$, né?

A outra, o outro cariótipo, qual que era?

Síndrome de Down

Síndrome de Down! Tinha um que era Síndrome de Down, que tinha três cromossomos 21 , estava sobrando um!

Então, realmente! Imagina uma das primeiras pesquisas ali, quando eles fizeram, né (...) esses cariótipos, "Ah, nossa, está sobrando um cromossomo". E aí eles foram pesquisar e identificar o que era isso.

Lá o Klinefelter, o Turner eram pesquisadores, e na verdade ele foram identificando ali alterações cromossômicas, né? "Está sobrando um, será que isso tem relação com os pacientes?"

Daí eles foram pesquisar (...) $\mathrm{SHHH}$ !

Eles foram pesquisar alguns pacientes e aí eles verificaram que todos tinham algum problema, tinham esse cromossomo a mais, tá?

Então esses cromossomos a mais que vocês identificaram, pode ser a síndrome.

E o cariótipo número 1, tinha problema? Era normal e era do sexo?

Masculino

Masculino, certo? Tudo bem? Algum problema aí? Vocês querem refazer e verificar? Quem não me entregar [agora] então entrega segunda-feira Segunda (indecifrável) quarta é feriado

Então podem guardar, vocês, Maria e João que estão fazendo agora. Pode guardar que (indecifrável)
Fornecer

evidências

Fornecer

evidências
Fala meio segundo depois da aluna, praticament e junto
Olha para um dos lados da sala para dar uma bronca.
Dois alunos falam ao mesmo tempo, não dá pra escutar um deles. Pega uma folha de exercício dada por um aluno e examina Conversa particularme nte com um aluno sobre o exercício 


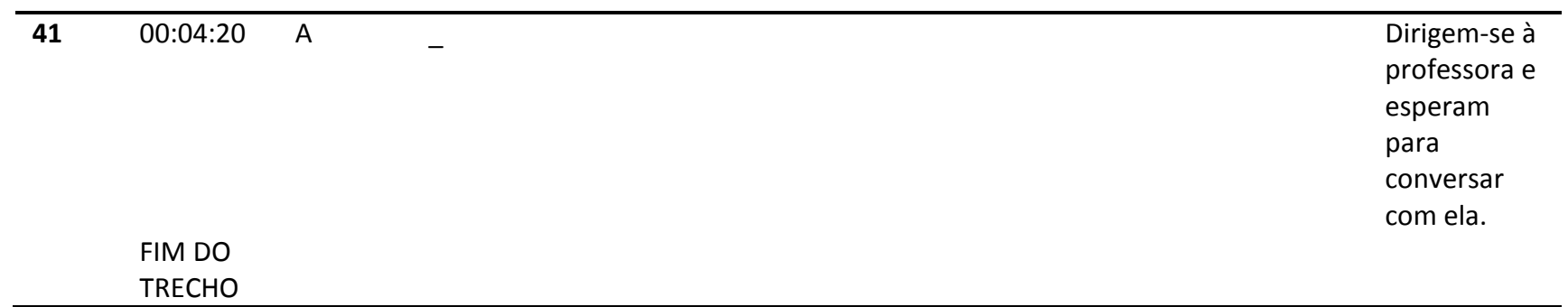

\begin{tabular}{|c|c|c|c|}
\hline Linha & Tempo & Pessoa & Fala \\
\hline 42 & 00:00:00 & $P$ & $\begin{array}{l}\text { Você tem um material genético. Esse material genético, a } \\
\text { natureza dele é de DNA e RNA. }\end{array}$ \\
\hline 43 & 00:00:09 & $P$ & Presta atenção na sua (indecifrável) \\
\hline
\end{tabular}

\begin{tabular}{|c|c|c|c|}
\hline 44 & 00:00:14 & $P$ & Indecifrável \\
\hline 45 & 00:00:16 & $P$ & Este DNA está organizado no núcleo na forma de (...) \\
\hline 46 & 00:00:31 & $\mathrm{P}$ & $\begin{array}{l}\text { É (...) pessoal, pessoal. Este DNA está organizado no } \\
\text { núcleo (...) ow, posso começar? }\end{array}$ \\
\hline 47 & 00:00:45 & $\mathrm{P}$ & $\begin{array}{l}\text { É (...) está organizado no núcleo na forma de cromatina } \\
\text { ou cromossomo, que são fios de DNA enrolados em } \\
\text { proteínas. }\end{array}$ \\
\hline 48 & & $\mathrm{P}$ & Mas, afinal de contas, do que é feito o DNA? \\
\hline & & $P$ & Vocês já começaram a ver lá na exposição, né? \\
\hline
\end{tabular}

50

51

52

53

$54 \quad 00: 01: 24 \quad P$

55
Mas vamos contextualizar agora como foi feita essa descoberta. Tá?

Então nessa ficha, o que é que eu fiz nessa ficha?

Eu coloquei em itens os eventos principais que eu vou explicar para vocês, tá?

Então além da ficha, peguem o caderno para complementar as informações, tá? Pegou o caderno (indecifrável)

Indecifrável

Olha, acho que é meio difícil anotar na folha, né, não tem quase espaço nenhum aqui, certo?
Chamando a atenção de uma aluna que olhava para trás para que passe as folhas de texto para trás.

Para de falar e espera os alunos que riem

Refere-se à visita feita à exposição do genoma.

Olhando para um aluno, em tom de bronca Fica implícito que a aluna perguntou se poderia anotar na própria folha Olhando para os espaços em branco na 
folha.

$\begin{array}{lll}\mathbf{5 7} & 00: 01: 40 & \mathrm{P} \\ \mathbf{5 8} & 00: 01: 42 & \mathrm{P} \\ & & \\ \mathbf{5 9} & & \mathrm{P}\end{array}$

60 00:02:12
Então (indecifrável)

Determinação dos componentes do núcleo. Então (...) é (...) vocês estão vendo aí que a data começa com 1879. Nós vimos lá na teoria celular que, por volta de mil (...) também 1850-1870, se estabeleceu, Maria, a teoria celular, né? A consideração de que todos os indivíduos são formados por célula.

Se observava já os cromossomos nas células (indecifrável), só que não se sabia a função desses cromossomos nem do que eles eram formados, né? Ao mesmo tempo, paralelamente, alguns experimentos bioquímicos foram sendo realizados para determinar, bom, do que é que é feito aquelas substâncias presentes no núcleo.

\section{Guarda senão eu vou pegar.}

Então, em 1879 [ou1859?], o pesquisador John Richards identificou em núcleos de glóbulos brancos um composto de natureza ácida, rico em fósforo e em nitrogênio, desprovido de enxofre e resistente à ação da pepsina, enzima que digere proteínas. E chamou esse composto de nucleína, porque ele estava presente no núcleo. Então, vamos explicar cada uma dessas coisas aqui.

Naquela época, já se conhecia, estavam começando a entender as proteínas. Se encontravam proteínas em várias estruturas celulares, né?

Então, sabia-se que a proteína estava na membrana sabiam que existiam várias proteínas no citoplasma da célula, né?

Proteínas estavam em todos os lugares da célula. Então, inclusive, acreditava-se que eram as proteínas, né? Elas fazem tudo, elas estão em todas as estruturas celulares, então, talvez também sejam as proteínas as responsáveis por guardar a informação hereditária, a informação que passa (...) de uma geração para outra, né?

Então, com essas ideias em mente (...). Na verdade, naquela época também não davam muita importância pro núcleo da célula. Eles acreditavam que o núcleo não tinha muita função, né?

Mas (...) esse pesquisador aqui começou a pesquisar o composto do núcleo e até achou que descobriu uma nova substância que não era proteína, por quê? Por que não era a proteína?

Por esse primeiro tópico (...)
Fornecer evidências

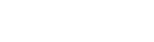

Ao final dessa fala, a professora aponta para uma aluna com expressão de bronca.

Leitura do texto

Fornecer evidências

Ao fim dessa fala se vira para a lousa

Escreve o título do texto na lousa e espera a resposta dos alunos

Hein?

O que é que está escrito aí na letra $A$, que me permite afirmar que essas substâncias presentes no núcleo, que, por causa disso ele chamou de nucleína. O que é que me permite dizer que essa substância não é uma proteína? Indecifrável

Murmurinho
Incitar justificativa 


\begin{tabular}{|c|c|c|c|c|c|}
\hline 75 & & $A$ & Indecifrável & & Murmurinho \\
\hline 76 & $00: 04: 54$ & $\mathrm{P}$ & $\begin{array}{l}\text { Ela digere proteína. Então, se fosse uma proteína, } \\
\text { quando eu colocasse (...) quando eu colocasse essa } \\
\text { substância em contato com a pepsina, o que é que iria } \\
\text { acontecer com essa proteína, João? }\end{array}$ & & \\
\hline 77 & & $A$ & Indecifrável & & Murmurinho \\
\hline 78 & 00:05:04 & $\mathrm{P}$ & $\begin{array}{l}\text { E o que é que é isso? O que é ser digerida? Quebrada em } \\
\text { quê? }\end{array}$ & & \\
\hline 79 & & $A$ & Indecifrável & & Murmurinho \\
\hline 80 & 00:05:09 & $\mathrm{P}$ & Em quê? & & \\
\hline 81 & & $A$ & Indecifrável & & Murmurinho \\
\hline 82 & 00:05:11 & $\mathrm{P}$ & $\begin{array}{l}\text { Em pequenas subunidades. Quais são as pequenas } \\
\text { subunidades das proteínas? }\end{array}$ & & \\
\hline 83 & & $A$ & Indecifrável & & Murmurinho \\
\hline 84 & 00:05:17 & $\mathrm{P}$ & Aminoácidos! Ãh? & & \\
\hline 85 & & $A$ & Indecifrável & & Murmurinho \\
\hline 86 & $00: 05: 24$ & $\mathrm{P}$ & $\begin{array}{l}\text { Mas é que o pequeno tem nome, ainda por cima, né } \\
\text { João, isso que é mais impressionante (indecifrável) }\end{array}$ & & \\
\hline 87 & & $A$ & Indecifrável & & Murmurinho \\
\hline 88 & 00:05:33 & $\mathrm{P}$ & Ah! É? [rindo] Quem sabe, né? & & \\
\hline 89 & 00:05:36 & $\mathrm{P}$ & $\begin{array}{l}\text { Então, o que é que acontece? Resistente à pepsina, então } \\
\text { não era proteína. Além disso, desprovido de (...) }\end{array}$ & $\begin{array}{l}\text { Fornecer } \\
\text { evidências }\end{array}$ & \\
\hline 90 & & $A$ & Indecifrável & & Murmurinho \\
\hline 91 & $00: 05: 45$ & $\mathrm{P}$ & $\begin{array}{l}\text { Enxofre! Em geral, as proteínas também, muitas } \\
\text { proteínas têm enxofre na sua composição, Maria. }\end{array}$ & & $\begin{array}{l}\text { Chama a } \\
\text { aluna para } \\
\text { que preste } \\
\text { atenção }\end{array}$ \\
\hline 93 & 00:05:53 & $\mathrm{P}$ & $\begin{array}{l}\text { É (...) e rico em fósforo e nitrogênio, tá? } \\
\text { As proteínas têm nitrogênio, mas não têm fósforo. E essa } \\
\text { substância tem fósforo, tá? }\end{array}$ & $\begin{array}{l}\text { Fornecer } \\
\text { evidências }\end{array}$ & \\
\hline 94 & & $\mathrm{P}$ & $\begin{array}{l}\text { Além disso, é uma substância ácida. Então, com essa, } \\
\text { com os experimentos bioquímicos, eles perceb(...), ele } \\
\text { começou a perceber o que tinha e o que não tinha nessa } \\
\text { substância. como não era uma proteína, ele deu um novo } \\
\text { nome aí de nucleína, tá? }\end{array}$ & & \\
\hline 95 & & $\mathrm{P}$ & $\begin{array}{l}\text { No entanto, mais ou menos durante vinte anos, muitos } \\
\text { pesquisadores duvidavam ainda desses experimentos do } \\
\text { Needham, por quê? Eles achavam simplesmente que } \\
\text { eram proteínas contaminadas aí com fosfato, que por } \\
\text { alguma razão foram resistentes foram resistentes à } \\
\text { pepsina, né? Então, achava-se que eram proteínas. Que } \\
\text { as proteínas eram as substâncias da célula, inclusive do } \\
\text { núcleo celular. Né? }\end{array}$ & & \\
\hline 96 & 00:06:52 & $\mathrm{P}$ & $\begin{array}{l}\text { Só que, vinte anos depois, na letra B, 1889(?) Richard } \\
\text { Altmann é (...) confirmou a natureza ácida desse } \\
\text { composto. Repetiu esses experimentos e verificou } \\
\text { realmente que era diferente das proteínas. E, como ele } \\
\text { era ácido, chamou de ácido nucléico, então ainda é um } \\
\text { nome genérico, sem saber muito bem a função, né? }\end{array}$ & $\begin{array}{l}\text { Fornecer } \\
\text { evidências }\end{array}$ & \\
\hline 97 & 00:07:19 & $P$ & $\begin{array}{l}\text { E aí, outra, outros pesquisadores, aí na letra C, foram } \\
\text { identificando outras substâncias no ácido nucléico. } \\
\text { (indecifrável) continha as bases nitrogenadas: adenina, } \\
\text { timina, citosina e guanina, que são carinhosamente } \\
\text { chamadas pela primeira letra, então, A, T, C e G, certo? }\end{array}$ & & $\begin{array}{l}\text { Desenha na } \\
\text { lousa a } \\
\text { estrutura da } \\
\text { pentose }\end{array}$ \\
\hline 98 & & $\mathrm{P}$ & $\begin{array}{l}\text { [Risos] E carboidratos, que tipo de carboidrato? Do tipo } \\
\text { pentose, então a estrutura química desses carboidratos } \\
\text { forma uma estrutura pentagonal, né? }\end{array}$ & & \\
\hline 99 & 00:07:59 & $\mathrm{P}$ & $\begin{array}{l}\text { Com cinco carbonos, tá? Então, tinha essas bases } \\
\text { nitrogenadas, bases nitrogenadas, contém muito o quê? }\end{array}$ & & \\
\hline
\end{tabular}




\begin{tabular}{|c|c|c|c|}
\hline 100 & & $\bar{A}$ & Indecifrável \\
\hline 101 & 00:08:10 & $\mathrm{P}$ & $\begin{array}{l}\text { Nitrogênio! Né? Então tudo se confirmando aquela } \\
\text { primeira pesquisa (indecifrável) }\end{array}$ \\
\hline 102 & 00:08:17 & $\mathrm{P}$ & $\begin{array}{l}\text { Aí, em 1900, verificou-se a presença de dois tipos de } \\
\text { ácidos nucléicos. Então dois tipos de ácido nucléicos. }\end{array}$ \\
\hline 103 & 00:08:33 & $P$ & $\begin{array}{l}\text { O DNA e o RNA. Então genericamente eles são chamados } \\
\text { de ácidos nucléicos. Uma substância de composição ácida } \\
\text { presente no núcleo. João. }\end{array}$ \\
\hline 104 & 00:08:47 & $\mathrm{P}$ & $\begin{array}{l}\text { Tá? E essas duas substâncias que ainda, logicamente (?) } \\
\text { ainda não se sabia a função. Por que dois tipos? }\end{array}$ \\
\hline
\end{tabular}

105

106

00:09:05 P

107

108

109

00:09:25 P

Porque, qual é a diferença entre eles? Do DNA e do RNA? Está escrito aí.

O que é que o RNA tem?

Ele tem quatro bases nitrogenadas, mas quais são as quatro bases nitrogenadas do RNA?

Adenina, tem timina? Não, tem uracila, citosina e guanina.

E o açúcar do RNA, qual que é? O carboidrato? É chamado de (...) ribose, tá?

E o que é aquela uracila?

É uma outra base nitrogenada, que também se descobriu aí nessa época, na verdade você tem cinco bases nitrogenadas só que os dois, cada um desses são formados por quatro bases nitrogenadas. O RNA pela adenina, pela uracila, pela citosina e pela guanina e o DNA pela adenina, pela timina, pela citosina e pela guanina, tá?

Murmurinho

Alguém

tosse, não

dá pra ouvir

a fala da

professora.

Repete

enquanto

escreve na

lousa

Aponta para

os dois

nomes

escritos na

lousa

Escreve na

lousa

enquanto

fala os

nomes das

bases. Há

um

murmurinho

, não dá pra

identificar se

algum aluno

fala os

nomes.

Escreve na

lousa

enquanto

fala. Há um

murmurinho

, não dá pra

identificar se

algum aluno

fala os

nomes.

Escreve e

aponta para

os termos da

lousa

enquanto

fala. Há

murmurinho

, percebe-se

a fala dos

alunos

completand

o a fala da

professora.

Então, na verdade, o DNA e o RNA têm na sua

composição a diferença de uma base nitrogenada, tá?

O DNA tem o T e o RNA não tem o T, mas tem o U, certo?

Além disso, qual outra diferença? O carboidrato do DNA 
é a ribose? Não, é a desoxirribose. Esse nome bonito aqui, desoxirribose.

115

$\mathrm{P}$

116

00:11:00 P

117

118

119

120

121

122

123

124

125

126

127

128

129

00:13:48 P

00:11:26 P

00:12:26 P

00:12:59 A

00:13:01 P

Por que desoxirribose? "oxi" de oxigênio, "des" de sem. Então, a desoxirribose tem um oxigênio a menos que a ribose, certo?

É (...) então essas são duas diferenças, diferenças estruturais, tá?

Entre esses ácidos nucléicos, tudo bem? A diferença na composição das bases nitrogenadas e a diferença no carboidrato.

A

A

Indecifrável

Ok? Então, já (...) olha só gente, já em 1900 esse nome já tinha sido cunhado, esses nomes, mas (...) sabia-se do que era composto, mas sabia-se como eles eram ligados? Essa estrutura. Não. Como que a base nitrogenada se ligava à desoxirribose ou à ribose, não se sabia como isso era ligado. Se sabia do que era composto em (...)1900, tá?

Aí, Âh (...) em 1912, outros dois cientistas, o Leveni (?) e o Jacob, Jacobs concluíram que o componente básico, lá na letra $E, 1 E$, o componente básico dos ácidos nucléicos era uma estrutura composta por uma base nitrogenada ligada a uma pentose, que por sua vez estava unida ao fosfato. Essa unidade foi denominada nucleotídeo. Um ácido nucléico seria uma molécula formada por uma série de nucleotídeos ligados entre si, ainda não se sabia como.

Então, o que ele diz aí? A estrutura do nucleotídeo. Então aqui eu tenho a pentose, que pode ser ribose ou desoxirribose, ligada a uma base nitrogenada, ligada a um grupo fosfato, tá? Então aqui é o carboidrato, aqui é uma base nitrogenada. Esta é a estrutura do nucleotídeo que tinha sido determinada em 1912. Isso é um nucleotídeo. Nucleotídeo

É (...) então, da mesma maneira que as proteínas são macromoléculas (...) Qual é a subunidade das proteínas?
Os alunos comentam sobre a professora falar inglês

Sobre a escrita no quadro. Sobre a escrita no quadro.

Se dirige à lousa para escrever. Desenha a estrutura molecular do nucleotídeo enquanto explica Murmurinho . Não dá pra identificar se 
132

133

$P$

$P$

134

A

00:15:50 P

00:15:50 P Os mono (...) sacarídeos, certo?

Aminoácidos, né? subunidades dos carboidratos?

135 alguém

responde

Então vários aminoácidos ligados formam uma proteína. Assim como carboidratos. "São" uma molécula grande, uma macromolécula, são polissacarídeos, são formados por, pela união de várias subunidades, quais são as

136

00:15:13 P

O DNA, os ácidos nucléicos, o DNA e o RNA também são macromoléculas formadas por subunidades. Quais são as subunidades do DNA e do RNA?

137 00:16:05 P Está aqui... [fala baixinho]

138

00:16:09 A

Nucleotídeos

139

00:16:10 P

Os nucleotídeos! (...) Certo?

141

00:16:36 A

142

143

144

$00: 16: 37$

$00: 16: 42$

$00: 16: 42 \quad P$

Então a subunidade do DNA e do RNA são os

nucleotídeos. Que São formados pelo quê, por sua vez? Por outras subunidades: um grupo fosfato, por isso que tem muito fósforo no DNA, ligado ao carboidrato que pode ser, se for uma desoxirribose é um DNA ou RNA? DNA

DNA! Se for formado por ribose, é DNA ou RNA?

RNA

RNA! Certo?
Aponta para

o esquema

de

nucleotídeo

Dá para

identificar a

fala de

alguém

Fala parte da palavra e

espera

alguém

completar e

fala junto

com um

aluno.

Fala

praticament

e junto com

$o$ aluno

quando vê

que ele

responde

certo.

Fala

praticament

e junto com

o aluno

quando vê

que ele

responde

certo.

Por sua vez esse carboidrato está ligado a uma base nitrogenada. Essa base nitrogenada pode ser o que? Pode ser um A, né? Uma adenina, pode ser uma timina, pode ser uma citosina, pode ser uma guanina, certo? No caso do (...) DNA. Pode ser uma adenina, pode ser uma uracila, pode ser uma citosina, pode ser uma guanina no caso do (...) RNA. Ok? Indecifrável 


\begin{tabular}{|c|c|c|c|c|c|}
\hline 148 & & $\mathrm{P}$ & Ãh? & & \\
\hline 149 & & A & [Não repete] & & \\
\hline 150 & 00:17:19 & $\mathrm{P}$ & $\begin{array}{l}\text { Aí, quero pular pro [item] } 3 \text {, porque o [item] } 2 \text { vai } \\
\text { relacionar o DNA como sendo o material hereditário, tá? } \\
\text { Uns experimentos que mostram isso. No [item] } 3 \text { a gente } \\
\text { continua aí com a estrutura do DNA. }\end{array}$ & & \\
\hline 151 & 00:17:39 & $\mathrm{P}$ & $\begin{array}{l}\text { Então, determinação da estrutura. Tínhamos algumas } \\
\text { informações, não se sabia como isso estava ligado, né? } \\
\text { Mas alguns experimentos aí de } 1949 \text { a } 1953 \text { mostraram } \\
\text { algumas, começaram a dar algumas pra finalmente } 1953 \\
\text { ser determinada a estrutura do DNA. }\end{array}$ & & \\
\hline 152 & 00:18:03 & $\mathrm{P}$ & $\begin{array}{l}\text { Então, Erwin Chargaff quantificou as bases nitrogenadas } \\
\text { em amostras de DNA de três espécies e diferentes órgãos } \\
\text { de indivíduos da mesma espécie. E quais foram as três } \\
\text { conclusões a que ele chegou? }\end{array}$ & $\begin{array}{l}\text { Fornecer } \\
\text { evidências }\end{array}$ & \\
\hline 153 & & $\mathrm{P}$ & $\begin{array}{l}\text { A composição de bases varia de espécie para espécie. } \\
\text { Então, se eu pegar o ser humano vai ter um determinado } \\
\text { número de bases numa célula. Se eu pegar um } \\
\text { chimpanzé, se eu pegar um verme, se eu pegar } \\
\text { Drosophila melanogaster, a mosca de fruta, né? }\end{array}$ & & \\
\hline 154 & & $\mathrm{P}$ & Vai ter um outro número de bases, certo? & & \\
\hline 155 & & $\mathrm{P}$ & $\begin{array}{l}\text { Se eu pegar dentro do ser humano, pegar vários órgãos: } \\
\text { músculo, coração, intestino, o olho, se eu pegar vários } \\
\text { órgãos humanos, se eu pegar várias células humanas e } \\
\text { quantificar o número de bases nitrogenadas, o que é que } \\
\text { tem? }\end{array}$ & & \\
\hline 156 & & $\mathrm{P}$ & $\begin{array}{l}\text { A mesma quantidade de bases nitrogenadas. E uma outra } \\
\text { coisa importante, em qualquer espécie, numa bactéria! } \\
\text { Numa barata! Numa ameba e no ser humano! A } \\
\text { porcentagem de bases adenina é igual a timina e a } \\
\text { porcentagem de bases citosina é igual a de guanina. Ele } \\
\text { começou a perceber que a quantidade de A é igual a de T } \\
\text { e a quantidade de C é igual à de G. E isso dá o } 100 \% \text { de } \\
\text { bases de cada célula, que é igual a todas as células da } \\
\text { mesma espécie e diferente nas diferentes espécies, ok? }\end{array}$ & & $\begin{array}{l}\text { Dirige-se à } \\
\text { lousa e } \\
\text { escreve as } \\
\text { porcentagen } \\
\text { s. }\end{array}$ \\
\hline 157 & 00:19:51 & $\mathrm{P}$ & Então, com isso, se começou a perceber o que? Que, né? & & \\
\hline 158 & & $\mathrm{P}$ & $\begin{array}{l}\text { Depois, com outros dados que a gente já vai falar, que o } \\
\text { A se liga com o T pra formar a molécula do DNA e o C se } \\
\text { liga com o G, certo? }\end{array}$ & & \\
\hline 159 & & $\mathrm{P}$ & $\begin{array}{l}\text { E aí, lá no resto da letra B, 1951, A Rosalind Franklin e o } \\
\text { Robins Wilkins (?), por difração de Raios-X determinaram } \\
\text { que o DNA tem uma estrutura helicoidal. Então vocês } \\
\text { viram lá. Depois que a gente saiu da célula, na exposição, } \\
\text { a primeira (...) montagem ali quando a gente entra } \\
\text { naquela sala Tinha a foto do Watson e Creek que é a } \\
\text { molécula de DNA e tinha a foto de uma mulher, né? }\end{array}$ & & $\begin{array}{l}\text { Ao falar } \\
\text { helicoidal, a } \\
\text { professora } \\
\text { faz } \\
\text { movimentos } \\
\text { no ar } \\
\text { imitando a } \\
\text { forma de } \\
\text { uma } \\
\text { helicoidal, } \\
\text { várias vezes. }\end{array}$ \\
\hline 160 & & $\mathrm{P}$ & Com uma foto da difração de raios-X, né? & & \\
\hline 161 & & $\mathrm{P}$ & $\begin{array}{l}\text { Que é a foto que ela tirou dessa molécula do DNA. E } \\
\text { verificou que tinha uma forma helicoidal, né, a forma de } \\
\text { uma (...) como se fosse uma escada caracol. Só que o que } \\
\text { é que aconteceu? }\end{array}$ & & \\
\hline 162 & & $\mathrm{P}$ & $\begin{array}{l}\text { Ela estava muito perto, eles estavam muito perto de } \\
\text { chegar nessa estrutura do DNA. Essa forma helicoidal } \\
\text { mostrou o que? Que talvez as bases nitrogenadas se } \\
\text { ligassem entre si. E os carboidratos e grupos fosfatos } \\
\text { ficassem circulando aí em volta das bases nitrogenadas. }\end{array}$ & & \\
\hline
\end{tabular}




\begin{tabular}{|c|c|c|c|c|}
\hline 163 & $00: 21: 22$ & $P$ & $\begin{array}{l}\text { E foi juntando todas essas informações que, em 1953, ou } \\
\text { seja, por (?) pouco tempo atrás, né? }\end{array}$ & \\
\hline 164 & & $P$ & Cinquenta e cinco anos, né? & \\
\hline 165 & & $P$ & $\begin{array}{l}\text { James Watson e Francis Creek elaboraram esse modelo } \\
\text { do DNA. E o que é que eles identificaram? Que, as bases } \\
\text { nitrogenadas são complementares. São complementares } \\
\text { seguindo a regra de Chargaff: A se liga com T e C se liga } \\
\text { com G, formando duas cadeias de DNA. Essas duas fitas } \\
\text { de nucleotídeos. Duas fitas de nucleotídeos. Desta } \\
\text { maneira. Certo? Então um nucleotídeo se liga com outro } \\
\text { pelas bases nitrogenadas. (indecifrável) ligações de } \\
\text { hidrogênio entre as bases nitrogenadas. E além disso, pra } \\
\text { formar a cadeia, pra formar as fitas, um nucleotídeo se } \\
\text { liga com o fosfato, né? }\end{array}$ & $\begin{array}{l}\text { Ao explicar a } \\
\text { estrutura, a } \\
\text { professora } \\
\text { vai à lousa e } \\
\text { completa o } \\
\text { desenho do } \\
\text { nucleotídeo, } \\
\text { ligando-o a } \\
\text { outro. }\end{array}$ \\
\hline 166 & & $P$ & $\begin{array}{l}\text { O carboidrato se liga com o grupo Fosfato de outro } \\
\text { carboidrato e outra base nitrogenada aí. Desta maneira } \\
\text { aqui. Tem as propriedades de um ácido, né? Quando } \\
\text { você mede o pH da água }\end{array}$ & \\
\hline 167 & $00: 23: 18$ & $P$ & $\begin{array}{l}\text { Essa é a estrutura básica, as ligações do DNA. Então se eu } \\
\text { tenho A aqui. A gente vai, depois, montar (...) se eu tenho } \\
\text { C aqui eu tenho G do outro lado. Então são vários tipos } \\
\text { de ligação. Essa estrutura, foram o Watson e Creek que } \\
\text { chegaram em 1953. Eles ganharam um prêmio Nobel } \\
\text { junto com o Wilkins. A Rosalind Driver, não, Driver, não, } \\
\text { [risos] eles entenderam porque é uma pesquisadora que } \\
\text { a gente estuda, mas Rosalind Franklin, ela morreu, então } \\
\text { o prêmio Nobel é só dado para pessoas vivas, e ela não } \\
\text { recebeu o prêmio Nobel. }\end{array}$ & \\
\hline & \multicolumn{4}{|c|}{ 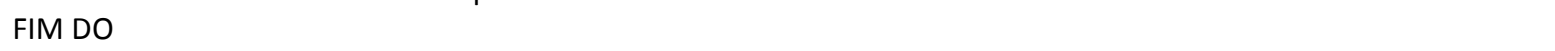 } \\
\hline & TRECHO & & & \\
\hline
\end{tabular}

\begin{tabular}{|c|c|c|c|c|c|}
\hline Linha & Tempo & $\begin{array}{l}\text { Pesso } \\
\text { a }\end{array}$ & Fala & $\begin{array}{l}\text { Ações pró- } \\
\text { argumentação }\end{array}$ & Observações \\
\hline 168 & $00: 00: 00$ & $P$ & $\begin{array}{l}\text { [começa no meio da fala da professora](...) né? } \\
\text { Normalmente fala: o DNA é uma estrutura dupla fita. } \\
\text { Porque ela tem essas duas cadeias ne nucleotídeo. } \\
\text { Continua aqui, né? Âh (...) }\end{array}$ & & $\begin{array}{l}\text { O trecho } \\
\text { inicia com a } \\
\text { professora } \\
\text { apontando } \\
\text { as estruturas } \\
\text { desenhadas } \\
\text { na lousa } \\
\text { (nucleotídeo } \\
\text { ) }\end{array}$ \\
\hline 169 & & $P$ & $\begin{array}{l}\text { Dispostas em hélice ao redor de um eixo imaginário aqui } \\
\text { no meio. As duas cadeias mantêm-se unidas por meio de } \\
\text { Pontes de Hidrogênio. Na verdade, não é mais ponte de } \\
\text { Hidrogênio. Ligações de Hidrogênio é o nome novo, né? }\end{array}$ & & \\
\hline 170 & & $P$ & $\begin{array}{l}\text { Entre os pares de bases específicos. Adenina com timina } \\
\text { tem duas ligações de hidrogênio, citosina com guanina tem } \\
\text { três ligações de hidrogênio }\end{array}$ & & \\
\hline 171 & 00:00:37 & $A$ & Indecifrável & & \\
\hline 172 & 00:00:38 & $P$ & Âh... & & \\
\hline 173 & 00:00:38 & $A$ & Indecifrável & & \\
\hline 174 & 00:00:39 & $P$ & "P". Fosfato. Aqui é o fosfato, tá? & & $\begin{array}{l}\text { Escreve o P } \\
\text { do grupo } \\
\text { fosfato no } \\
\text { esquema da } \\
\text { lousa e } \\
\text { aponta para } \\
\text { os grupos }\end{array}$ \\
\hline
\end{tabular}


fosfato do

esquema

175

00:00:47 P

176

177

178

179

180

181

182

00:00:15 A

00:00:19 P

00:00:20 A

00:00:22 P

183

00:01:26 P

Âh (...) As duas cadeias são complementares, o que isso significa?

Onde tem um $A$ tem um $T$, onde tem um $T$ tem um $A$. onde tem um $\mathrm{C}$ tem um $\mathrm{G}$, onde tem um $\mathrm{G}$ tem um $\mathrm{C}$. Tá?

Aponta na

lousa as

bases

complement

ares.

Concorda e escreve no esquema

A com $t, c$ com $\mathrm{g}$. Isso vocês têm que decorar. O que acontece, eu não sei, mas AconTeCe com G. Tá? [risos]

Professora

Âh...

Aquela bolinha [do esquema] também é P?

Também é P. (indecifrável) tá?

Outra coisa importante! As duas fitas são antiparalelas.

Vocês repararam na direção que eu desenhei aqui os carboidratos? Que, na verdade é uma desoxirribose, um DNA. Uma está com a pontinha lá para cima e outra está com a pontinha aqui para baixo. Então, elas são chamadas de antiparalelas. Elas são paralelas, mas cada uma está em uma direção diferente, ok?

184 00:01:54 P E ficou conhecido como modelo da dupla hélice.

185 00:01:58 P Então nós vamos fazer a ligação do DNA aqui para todo mundo perceber. É rapidinha, cinco minutos. Todo mundo, a gente vai pra lá [aponta o fundo da sala]

FIM DO TRECHO - CORTA A FALA NO

MEIO

\begin{tabular}{|c|c|c|c|c|c|}
\hline Linha & Tempo & Pessoa & Fala & $\begin{array}{l}\text { Ações pró- } \\
\text { argumentação }\end{array}$ & Observações \\
\hline 186 & 00:00:01 & $P$ & $\begin{array}{l}\text { [começa no meio da fala da professora](...) no } \\
\text { carboidrato do outro, certo? Então a minha mão no } \\
\text { ombro do outro. }\end{array}$ & & $\begin{array}{l}\text { Faz um } \\
\text { ângulo reto } \\
\text { entre o } \\
\text { ombro } \\
\text { direito e o } \\
\text { torso e abre } \\
\text { o braço } \\
\text { esquerdo a } \\
180^{\circ} \text { do } \\
\text { peitoral. }\end{array}$ \\
\hline 187 & 00:00:09 & $\mathrm{P}$ & $\begin{array}{l}\text { E aqui no meio, as ligações de hidrogênio. Não se } \\
\text { esqueçam que as fitas são antiparalelas, certo? }\end{array}$ & & \\
\hline 188 & 00:00:15 & $\mathrm{P}$ & $\begin{array}{l}\text { Então vamos lá, vai. Todo mundo ali no meio para a } \\
\text { gente fazer o DNA }\end{array}$ & & \\
\hline Linha & Tempo & Pessoa & Fala & $\begin{array}{l}\text { Ações pró- } \\
\text { argumentação }\end{array}$ & Observações \\
\hline 189 & $00: 00: 02$ & $P$ & [Respondendo a uma aluna] Não precisa, não precisa. & & $\begin{array}{l}\text { Todos os } \\
\text { alunos estão } \\
\text { de pé, no } \\
\text { corredor } \\
\text { entre as } \\
\text { duas } \\
\text { bancadas de } \\
\text { laboratório } \\
\text { da sala. }\end{array}$ \\
\hline
\end{tabular}


Só que as duas fitas são antiparalelas, Então, se uma, se

191

192 00:00:33 P

193

194

00:00:49 P

195

00:01:23 P

196 00:01:29 P

197

00:01:32 A

198 00:01:33 P

199 00:01:38 A

200 00:01:40 P

201 00:01:41 A

202 00:01:42 P

203 00:01:59 P

204 00:02:16 A

205

206

207

208

00:02:26 P

00:02:32 $\quad$ P

209

00:02:50 A

210

00:02:52 P

$21100: 03: 06 \quad P$ um está virado para lá, uma fileira, para lá, todo mundo virado para lá. E essa fileira [a outra], virada para lá [aponta o lado oposto] [muito barulho - conversas paralelas]

E aí, vocês têm que se dar a mão aqui no meio. E colocar a mão (indecifrável) [no ombro do colega]

[os alunos começam a se arrumar e copiam uns aos outros para tentar representar a estrutura]

Essa é, gente! Cada um de vocês, oh! Fosfato em um [braço], carboidrato no outro [braço]. Aqui no meio (indecifrável) nitrogenadas ligadas pelas ligações de Hidrogênio

Essa é a estrutura do DNA.

Essa mão [segurando a mão da aluna da ponta da cadeia] fica solta

Ah é?

É. Essa fica solta, aqui pra frente

Ahhhh [desanimada]

Está certo?

E o nosso corpo?

O corpo nosso é o carboidrato, igual à pentose. Então, fosfato (indecifrável) ["se liga" à pessoa da frente pelo ombro] (indecifrável), tá? E as ligações de hidrogênio aqui, ok?

Se acaso, depois a gente vai ver o que acontece (indecifrável) com o DNA, tá? Mas posso ter (indecifrável) [passa por entre os alunos "quebrando" as ligações de Hidrogênio]. Vamos supor, aqui, pessoal! Se a Maria for uma Timina, a outra Maria então é uma?

(indecifrável) [o aluno faz uma piada com a resposta e todos riem]

Adenina [vários alunos respondem em tempos

diferentes]

Se o João é um C, então o outro João é o?

$\mathrm{G}$ [vários alunos respondem em tempos diferentes]

Tá? Então essa é a complementariedade, Se por acaso

(...) se por um acaso ocorrer algum erro no DNA. Eu expulso a Maria [que havia representado a adenina] e entra um C [a professora representa o C]. A gente vai conseguir se ligar aqui?

Não

Não. A gente vai ser uma? Meninos! Vai ser uma mutação [explica para poucos que ouvem], tá?

Ok? Entenderam a (indecifrável) do DNA? [dispensa a turma - fim da aula] FIM DO TRECHO

Aula 7II - 23/04/2008 - 3의

\begin{tabular}{|c|c|c|c|c|c|}
\hline Turno & Tempo & Pessoa & Falas & $\begin{array}{l}\text { Ações pró- } \\
\text { argumentação }\end{array}$ & Observações \\
\hline 1 & $00: 01: 12$ & $P$ & Pessoal, & & \\
\hline 2 & $00: 01: 40$ & $\mathrm{P}$ & $\begin{array}{l}\text { é (...) então vamos lá gente. Na aula passada, a gente } \\
\text { definiu a estrutura do DNA, não é? Então estamos } \\
\text { (...), onde estamos? }\end{array}$ & & \\
\hline 3 & 00:01:53 & $P$ & aqui oh & & barulho na sala \\
\hline
\end{tabular}




\begin{tabular}{|c|c|c|c|c|}
\hline 4 & 00:02:05 & $\mathrm{P}$ & $\begin{array}{l}\text { Do indivíduo, fomos para a célula, núcleo da célula, } \\
\text { dentro do núcleo da célula, cromatina, cromossomo, } \\
\text { é (...) Maria, o que é que é cromatina mesmo? }\end{array}$ & \\
\hline 5 & $00: 02: 25$ & A & Cro(...)ma (...) & \\
\hline 6 & $00: 02: 27$ & $P$ & Cromatina, pegue seu caderno, fica mais fácil. & \\
\hline 7 & 00:02:40 & $\mathrm{P}$ & o que é que é cromatina mesmo? & \\
\hline 8 & $00: 02: 44$ & A & G1, S1 (...) não & risos \\
\hline 9 & $00: 02: 49$ & $\mathrm{P}$ & Isso é o ciclo celular & \\
\hline 10 & & A & Fios $(\ldots)$ & $\begin{array}{l}\text { muito barulho } \\
\text { junto }\end{array}$ \\
\hline 11 & $00: 02: 55$ & $P$ & fios do que? & \\
\hline 12 & 00:02:56 & $A$ & de DNA & \\
\hline 13 & $00: 02: 57$ & $\mathrm{P}$ & $\begin{array}{l}\text { fios de DNA enrolados em proteínas. Isso. Então na } \\
\text { verdade nós estamos lá: célula, núcleo da célula, } \\
\text { SHHH Joao, } \\
\text { núcleo da célula, ow meninos, eu não vou mais } \\
\text { chamar a atenção daquelas duas colunas lá. }\end{array}$ & \\
\hline 15 & $00: 03: 24$ & $\mathrm{P}$ & $\begin{array}{l}\text { Então na célula, dentro do núcleo da célula. No } \\
\text { núcleo da célula nós temos aí fios de DNA que } \\
\text { dependendo da fase do ciclo celular podem ser } \\
\text { chamados de cromatina ou cromossomo, certo? } \\
\text { Então se estivesse no G1, fase } S, G 2 \text {, esses fios são } \\
\text { chamados de? }\end{array}$ & \\
\hline 16 & 00:03:58 & A & Cromatina. & \\
\hline 17 & 00:03:59 & $P$ & $\begin{array}{l}\text { Cromatina. Então fios de DNA enrolados nas } \\
\text { proteínas, mas eles estão um pouco mais esticados, } \\
\text { certo? Se eles estão na mitose, na divisão celular } \\
\text { propriamente dita, eles são chamados de? }\end{array}$ & \\
\hline 18 & $00: 04: 14$ & $A$ & Cromossomos. & \\
\hline 19 & $00: 04: 15$ & $\mathrm{P}$ & $\begin{array}{l}\text { Cromossomos. Então é um nome diferente pra } \\
\text { mesmo estrutura. Só que em estágios diferentes do } \\
\text { ciclo celular, tá Maria? Então isso que você falou é o } \\
\text { ciclo celular, é o ciclo de vida de uma célula. Tá? }\end{array}$ & \\
\hline 20 & $00: 04: 38$ & $P$ & $\begin{array}{l}\text { E na aula passada, o que a gente fez? A gente pegou } \\
\text { isso daqui, falou do que é que é feito a cromatina e o } \\
\text { cromossomo? São feitos de DNA. E por sua vez, o } \\
\text { DNA é feito do que? }\end{array}$ & \\
\hline 21 & $00: 04: 58$ & $P$ & $\begin{array}{l}\text { Como que ele é feito? Como ele é formado? Qual a } \\
\text { estrutura bioquímica do DNA? E aí vocês fizeram um } \\
\text { desenhinho parecido com isso, certo? }\end{array}$ & \\
\hline 22 & $00: 05: 16$ & $A$ & não & \\
\hline 23 & $00: 05: 17$ & $P$ & não assim. & \\
\hline 24 & $00: 05: 27$ & $\mathrm{P}$ & Não foi isso? & \\
\hline 25 & $00: 05: 29$ & $A$ & Não & \\
\hline 26 & $00: 05: 30$ & $\mathrm{P}$ & Como não? & \\
\hline 27 & 00:06:04 & $P$ & $\begin{array}{l}\text { Então o DNA formado por dupla fita, então uma fita } \\
\text { aqui e outra fita de uma estrutura chamada de } \\
\text { nucleotídeo. Que, por sua vez é formada por, que, } \\
\text { por sua vez é formada por um grupo fosfato, um } \\
\text { carboidrato, que no caso do DNA, que no caso do } \\
\text { DNA qual é o nome do carboidrato? }\end{array}$ & \\
\hline 28 & 00:06:37 & $P$ & DNA & \\
\hline 29 & 00:06:40 & $P$ & $\begin{array}{l}\text { DNA é o DNA é que chama ácido desoxirribonucléico, } \\
\text { né? Mas o carboidrato, o açúcar. }\end{array}$ & \\
\hline 30 & 00:06:49 & $P$ & De - soxirribose & \\
\hline 31 & 00:06:53 & $P$ & E aqui é o que? & \\
\hline
\end{tabular}




\begin{tabular}{|c|c|c|c|}
\hline 32 & 00:06:57 & $P$ & Um C ou G ou a t que são bases nitrogenadas. \\
\hline 33 & 00:07:04 & $\mathrm{P}$ & $\begin{array}{l}\text { A desoxirribose é uma subunidade do nucleotídeo, } \\
\text { que por sua vez é a subunidade vários nucleotídeos } \\
\text { ligados, formam o DNA. Como que os nucleotídeos } \\
\text { estão ligados? Um está ligado pelo, com o outro pelo } \\
\text { fosfato e açúcar, né? Que nem a gente fez lá, né, } \\
\text { lembra da aula passada? Né? Um braço no ombro do } \\
\text { colega e também estão ligados pelas bases } \\
\text { nitrogenadas. Né? }\end{array}$ \\
\hline 34 & 00:07:35 & $\mathrm{P}$ & Como eles estão ligados pelas bases nitrogenadas? \\
\hline 35 & 00:07:39 & $\mathrm{P}$ & qual é a regra de ligação? \\
\hline 36 & $00: 07: 42$ & A & $A \operatorname{com} T$ \\
\hline 37 & 00:07:43 & $\mathrm{P}$ & $\begin{array}{l}\text { A com } T \text {, se aqui for } A \text {, com certeza aqui é } T \text {, se aqui } \\
\text { for } C \text {, aqui com certeza é } g . A(\ldots)\end{array}$ \\
\hline 38 & 00:07:51 & $P$ & Professora, \\
\hline 39 & 00:07:52 & $\mathrm{P}$ & $\begin{array}{l}\text { só pra completar Joao, a e t, Shh a e t são ligados por } \\
\text { duas ligações de hidrogênio c e g por três ligações de } \\
\text { hidrogênio, ok? Fala Joao }\end{array}$ \\
\hline 40 & 00:08:09 & A & o que é o nucleotídeo? \\
\hline 41 & 00:08:10 & $\mathrm{P}$ & O nucleotídeo é isso daqui olha. \\
\hline 42 & 00:08:15 & $\mathrm{P}$ & $\begin{array}{l}\text { isso é o nucleotídeo, tá? Essa estrutura é o } \\
\text { nucleotídeo. Que é um fosfato, ligado com um } \\
\text { açúcar, ligado com uma base nitrogenada. Isso serve } \\
\text { tanto pro DNA como pro RNA, tá? Só que aí você } \\
\text { tem: se for DNA qual é o açúcar? Desoxirribose. Se } \\
\text { for RNA, qual é o açúcar? Ribose. }\end{array}$ \\
\hline 43 & $00: 08: 42$ & $\mathrm{P}$ & $\begin{array}{l}\text { As bases nitrogenadas são cinco no total, só que o } \\
\text { DNA tem quatro. Quais são as bases nitrogenadas do } \\
\text { DNA? }\end{array}$ \\
\hline 44 & 00:08:50 & A & $A$ \\
\hline 45 & 00:08:51 & $\mathrm{P}$ & A, T, C e G. Se for RNA, quais são as quatro bases? \\
\hline 46 & 00:08:57 & $A$ & A \\
\hline 47 & 00:08:58 & $\mathrm{P}$ & $\begin{array}{l}\text { A, U, C e G, certo? Sempre com essa regra, a com t c } \\
\text { com G, ou no RNA a com u, c com g, ok? }\end{array}$ \\
\hline 48 & 00:09:12 & $\mathrm{P}$ & $\begin{array}{l}\text { Sendo que outra diferença entre o DNA e o RNA é: o } \\
\text { DNA é dupla fita, as bases nitrogenadas estão ligadas } \\
\text { por ligações de hidrogênio, certo? O RNA é uma fita } \\
\text { única, as bases nitrogenadas ficam soltas aí, tudo } \\
\text { bem? Uma outra diferença aí entre o DNA e o RNA, } \\
\text { tudo bem? ok? }\end{array}$ \\
\hline 49 & 00:09:38 & $\mathrm{P}$ & Tudo bem, Maria? \\
\hline 50 & & $\mathrm{P}$ & (inaudível) \\
\hline 51 & 00:09:45 & $\mathrm{P}$ & $\begin{array}{l}\text { No DNA você tem os nucleotídeos, né? Ligados pelas } \\
\text { bases nitrogenadas por meio de ligações de } \\
\text { Hidrogênio. No RNA não, é uma fita só. Só um lado }\end{array}$ \\
\hline 52 & 00:10:01 & A & O RNA também tem nucleotídeo? \\
\hline 53 & 00:10:03 & $\mathrm{P}$ & $\begin{array}{l}\text { Também. Então no núcleo, nós temos dois tipos, } \\
\text { lembram, que a gente viu também? No núcleo nós } \\
\text { temos dois tipos de ácidos nucléicos. Que é o nome } \\
\text { genérico, ácidos nucléicos, no núcleo. Que é o nome } \\
\text { genérico para DNA e RNA. A cromatina, vejam } \\
\text { prestem bem atenção nisso e anotem isso, a } \\
\text { cromatina e o cromossomo, eles são formados só por } \\
\text { DNA, tá? O RNA ele vai ter outra função e vai ser } \\
\text { encontrado tanto no núcleo como no citoplasma, tá? } \\
\text { Quando a gente verificar a função deles, daí vai ficar } \\
\text { claro isso. Tá? Mas a cromatina e o cromossomo são } \\
\text { fios de DNA enrolados em proteínas. O RNA vai ser }\end{array}$ \\
\hline
\end{tabular}


encontrado tanto no núcleo como no citoplasma e vai ter outra função na célula.

54

00:11:10 P

55

$00: 11: 24 \quad P$

56

57
Também são formados, tanto um quanto outro em termos estruturais, são formados por nucleotídeos. Sua subunidade é chamada de nucleotídeo, certo? Então DNA e RNA são grandes partículas, grandes moléculas, ligadas é (...) as suas subunidades são ligadas formando aí essa grande molécula. Qual é a subunidade do DNA e do RNA? Os nucleotídeos.

Certo?

Sendo que esses nucleotídeos tem algumas diferenças. É a mesma forma aí, só que o açúcar é diferente e as bases, uma das bases são diferentes também, ok?

Então isso pra retomar o que a gente já viu. A gente vai ver bastante isso aqui. Então esses nomes também, esses nomes que eu falei hoje são importantes, tá? Tem que decorar, não tem jeito, senão a gente fala, vai falar linguagens diferentes. Tá? A gente tem que se comunicar, vocês tem que saber esses termos, o significado dessas palavras.

Ah (...) na aula de hoje a gente parte pro item dois dessa ficha. Então determinada a estrutura do DNA, ao mesmo tempo, os pesquisadores queriam entender a função do DNA. Qual é a função do DNA? Uma coisa é a estrutura, tudo bem? O que essa estrutura possibilita? né?

é (...) e aí, começa a ideia, essa relação entre (...) do DNA como sendo o material hereditário, como sendo a base das informações que passam de uma geração para a outra. Mas como é que os pesquisadores determinaram isso? Como é que isso foi ah (...) não descoberto, mas esclarecido, determinado? Então, por isso que o título é: experimentos que relacionam o DNA com sendo o material genético.

Então, naquela época, final do século XIX começo do século XX, eles já sabiam muito sobre as proteínas. Eles encontravam proteínas em todas as partes das células. Então, do que é que é feita a membrana plasmática, por exemplo, ou a membrana do núcleo? Lembram? Lipídios e proteínas, então a proteína está lá. Qualquer reação química que acontece na célula depende de enzimas e enzimas são proteínas. Então as enzimas participam de todos os processos celulares, de todos. E existem milhares de tipos diferentes de proteínas. Então eles estavam achando naquela época, final do século dezenove, começo do século vinte, que porque não as proteínas, que fazem parte de toda célula, que fazem parte de todas as reações químicas que acontecem na célula. Por que não as proteínas que contém a informação genética, a informação hereditária? A informação que determina as características daquela célula e que determina a passagem da informação de uma célula para a outra, ou de um ser vivo para o outro.

Por que não, né? Se as proteínas fazem tudo, por que é que elas não fazem isso também? Mas, alguns 
experimentos mostraram que as coisas não eram bem assim. Então a gente vai discutir aí dois grandes experimentos pra verificar isso.

$62 \quad 00: 15: 04 \quad P$
Então, aí no item 1: a identificação do material hereditário em bactérias. Então, um pesquisador lá no início do século vinte, ele sabia que (...) uma espécie aí de bactérias, a Streptococcus pneumoniae é o nome dela, né?

(inaudível)

Eles sabiam que existia duas linhagens dessa espécie de bactérias, de Streptococcus. A linhagem S e a linhagem $R$, está aí na ficha de vocês. $E$ a linhagems $S$ produz uma cápsula de carboidrato e causa pneumonia em camundongos. E a linhagem R não produz essa cápsula e não causa a pneumonia em camundongos. Então, provavelmente esta cápsula está ligada com a sobrevivência da bactéria no corpo do indivíduo, do camundongo. Se ela tem essa cápsula, ela fica mais resistente lá, né? Às células de defesa do camundongo e acaba se reproduzindo causando um dano no organismo do hospedeiro, certo, causando a doença.

Se ela não tem aquela cápsula de carboidratos, então ela fica mais vulnerável ao ataque, por exemplo, né, das células de defesa lá do camundongo, que conseguem matá-la que acaba não se reproduzindo e não causando a doença no camundongo. Certo? Então se sabia dessas informações, se verificava ao microscópio essas bactérias e aí, lá no 1.a. Em 1928, Fred Griffiths ele fez os seguintes experimentos: ele pegou quatro grupos de camundongos.

nossa

O que é isso?

camundongos, ratinhos, orelhas,

nossa

Bom, mas acreditem, isso são camundongos, tá bom, acreditem.

é (...) o que é que ele fez, esse cientista? Ele pegou quatro grupos de camundongos e inoculou bactérias diferentes, pegou quatro grupos de camundongos e inoculou.

Inoculou?

Inoculou, injetou, né? As bactérias no corpo desses camundongos. Tá? É (...) então inolcular é inocular uma vacila, tá? Injetar.

é (...) so que como ele fez? Ele pegou bactérias da linhagem $S$ vivas e colocou no primeiro grupo de camundongos. O que é que aconteceu com os camundongos?

pegaram pneumonia e morreram

oh, não, gente, cobaias, tá? Camundongos criados aí pra experimentação, tá? Todos iguais, da mesma linhagem também, pra não haver diferença dos resultados, tá? O que ele mudou aqui foi o que? Foi a forma como as bactérias, né os tipos de bactérias inoculadas. Então, no primeiro grupo de camundognos ele coloca as bactérias $S$ vivas. A S, tá reclama em tom de brincadeira

risos

muitos comentários
Conferir evidências

Fornecer evidências 
la, causa pneumonia e causa a morte dos camundongos. Então ele inoculou bactérias $\mathrm{S}$ vivas e os camundongos pegaram pneumonia e morreram. Aí ele pegou e testou também as $R$ vivas, pegou bactérias $R$ vivas. Ow João, senta direito.

$$
\text { Joao, }
$$

Inoculou, Shh bactérias $\mathrm{R}$ vivas no camundonogo e o que é que aconteceu?

Sobreviveu. As R não causam pneumonia e aí eles sobreviveram felizes da vida, né? Não foi dessa vez que eles morreram. $\mathrm{O}$ outro grupo de camundongos ele pegou as bactérias $S$ matou as bactérias com calor, certo? Então ele matou as bactérias. E inoculou essas bactérias mortas pelo calor nos camundongos e aí o que a gente espera que acontecesse? Sobrevivessem.

Que eles sobrevivessem. As bactérias S estão mortas e realmente foi isso o que aconteceu. Eles sobreviverem, certo?

$E$, depois, o que é que ele fez? Vejam: ele pegou bactérias $S$ mortas pelo calor mais $R$ vivas. $S$ mortas: ratinho sobrevive, $R$ vivas: ratinho sobrevive. $O$ que é que então, ele esperarei que acontrecesse aqui? Que eles sobrevivessem, mas o que é que aconteceu?

\section{Morreu}

E aí? Era um resultado esperado?

Não professora.

Não era um resultado esperado, certo?

Vocês entenderam que não era um resultado esperado?

Então o que é , quais seriam hipóteses que a gente poderia levantar para explicar esse resultado não esperado?

Qual é? Que hipótese a gente(...) O que é que aconteceu gente? Não é a S viva que causa a morte desse camundongo?

Aqui as $\mathrm{S}$ estão mortas. As $\mathrm{R}$ vivas não causam morte do camundongo, não causam pneumonia. Que hipótese pode ser levantada daí. O que é que eles imaginaram quepode ter acontecido?

As duas juntas

As duas juntas causaram alguma coisa, mas é a bactéria viva, necessariamente? Alguma coisa dessa bactéria que causa a pneumonia a outra causa alguma coisa professora? a outra não causa nada. Né? Tanto é que ele sobreviveu aqui, essa não causa nada. Essa sim, essa causa a morte do bicho. Né? Só que eu matei ela pelo calor. Se eu matei pelo calor, mas as outras estruturas estão lá, certo? Então, o que é que eu imagino aqui?

$97 \quad 00: 23: 07 \quad \mathrm{~A} \quad$ (inaudível)

$98 \quad 00: 23: 09 \quad P \quad$ Oi?
Conferir evidências Conferir e fornecer evidências

Fornecer evidências Fornecer evidências

Conferir evidências

Fornecer barulho na sala evidências

Em tom jocoso. 
$99 \quad$ 00:23:14 $\quad P \quad$ Não não. Isso aqui é um outro ser vivo, não tem nada a ver. Na verdade, o que é que acontece? Pessoal! É (...) por que é que elas causam pneumonia. Por que é que a $S$ causa pneumonia? Ela se instala ali nas células do sistema respiratório e vai se reproduzindo, a bactéria. E aí, para, nesta reprodução, ela vai aí destruindo aí as células saudáveis do indivíduo, então não tem nada a ver com gripe aqui. Isso é um outro ser vivo, elas mesmas, pela sua reprodução elas vão infectando o organismo, aquele (inaudível), vão pegando todos os nutrientes do ambiente, né? E a células do próprio indivíduo vão morrendo tá? então isso seria a doença, tá?

$100 \quad 00: 24: 13 \quad P$

$101 \quad 00: 24: 55 \quad P$
Não. Então eu teria que (...) os cientistas tinham que imaginar uma outra situação, né? Para explicar esse resultado.

Então a S viva consegue se reproduzir no corpo do indivíduo, certo? por quê? Porque ela não tem lá aquela cápsula de carboidrato, então ela vai, se reproduz, causa uma pneumonia muito forte, então atinge os pulmões e pode até causar a morte do rato. Certo? A R não. Por que é que não? Por que ela não tem aquela cápsula e ela consegue ser morta pelos (...) pelas células de defesa do próprio rato antes de se reproduzir e destruir os tecidos do pulmão. Só que a $\mathrm{S}$ morta pelo calor, nós matamos a bactéria, oh pessoal, acompanha o raciocínio aqui João.

Nós matamos a bactéria, tá? Então colocamos, nós fervemos a cultura de bactérias a mais de $100^{\circ}$ elas morreram, certo? E quando isso foi colocado no Não se reproduziu, né? Pra ela se reproduzir ela precisa estar viva.

Só que quando eu juntei bactérias mortas com bactérias $\mathrm{R}$ aí tem um resultado completamente inesperado, por que? O ratinho pegou pneumonia e morreu. A gente poderia pensar o que? Que a bactéria $\mathrm{S}$ morta ressuscitou, por exemplo, certo? Poderia pensar isso? Mas é plausível? Em termos científicos.

Não

Não fui eu.

Para explicar esse resultado. O que é que eles imaginaram? Alguma coisa. (inaudível) causa a doença, certo? a S está morta, mas as suas estruturas ainda estão lá. Alguma coisa da $\mathrm{S}$, que aí ficou ainda preservada ali pelo calor, né? Foi incorporada pela $\mathrm{R}$ e aí a $\mathrm{R}$ que tá viva deve ter se transformado em $\mathrm{S}$ viva. Então essa foi a hipótese dos cientistas.

O princípio, como eles chamam aí de transformação bacteriana. Porque a bactéria $R$ foi transformada em bactéria S. Então, em contato, sozinho? Do nada? camundongo, não causou pneumonia, estava morta.
Fornecer

evidências

\begin{abstract}
Alguns alunos falam juntos, mas alguns deles falam que sim. Não dá pra entender se eles estão falando sério.
\end{abstract}

Fornecer

evidências 
Não. Em contato com as bactérias $\mathrm{S}$ mortas. Então alguma coisa da $\mathrm{S}$ morta, algum princípio transformante, (inaudivel)genérico porque eles não sabiam o que era esse princípio transformante. Foi incorporado pela $\mathrm{R}$ e a $\mathrm{R}$ viva se transformou em $\mathrm{S}$. Certo?

112

113 00:27:26 P

114

00:27:59

115

00:28:08

116

00:28:16 P

00:29:14 P

118

00:29:24 P

119

00:29:33 P

120

00:29:48 P

121

00:29:53 P

122

00:30:03 P

123

00:30:14 P (inaudível)

Então a $R$ morta, ela vai ser diferente da $R$ viva? A $R$ viva não causa doença. Então a $R$ morta também não. Certo? E a S viva também causa a doença. Então não faz diferença colocar $\mathrm{R}$ morta ou $\mathrm{R}$ viva. $\mathrm{O}$ que importa é a R viva porque ela, na verdade, como ela ta viva, foi ela que se transformou em $S$ por alguma coisa que estava lá na $\mathrm{S}$ morta. tá?

Então, entenderam aí essa confusão? Essa confusão dele, João.

(inaudível) e explica aí por que é que aconteceu isso nesse experimento. Mas eles sabiam do que era feito o princípio tranformante?

Não sabia. Outros experimentos foram feitos, ainda em 1944, então, outro pesquisador, Oswald Avery, verificou que essa transformação bacteriana ocorria também in vitro. O que significa isso? Que não somente ocorria num ser vivo, mas se eu pegasse num tubo de ensaio, né? $E$ pegasse bactérias $S$ mortas, mais bactérias $R$ vivas, o que é que eu teria depois de um tempo? Se eu fosse analisar as bactérias do tubo de ensaio, eu teria bactérias $S$ vivas então ele notou que isso acontecia também in vitro, fora do corpo dos camundongos, aí, fora do corpo dos seres vivos. isso propiciava que ele poderia fazer uma grande quantidade de bactérias pra poder estudar o que fosse esse princípio transformante. $\mathrm{O}$ que tranformou as bactérias R em S, certo? Então, o que é que ele fez? Próximo item aí. Colocou, pegou essas bactérias $\mathrm{R}$ transformadas $\mathrm{e}$ Olha, Joao, joao e joao, vou mandar pra fora. Foi, já estou no item 1.c.

Então olha só. Por que é que essa historinha também é importante. Não é de uma hora pra outra que o conhecimento é estabelecido.

Vc tem lá em 1928 tem esse experimento que chegou a essa hipótese, mas eles não sabiam explicar essa hipótese, né? Da transformação bacteriana, o que é que causava, como acontecia.

Aí em 1944 eles viram que aconteceu em tubo de ensaio o que facilitava o experimento, por que? Porque agora ele podia isolar esse princípio transformante. E foi o que eles fizeram. Olha lá no final da página. Um colaborador de Avery verifcou que a adição de álcool, ao extrato de bactérias $S$ causava a formação de um precipitado espesso que retinha o princípio transformante. Então o que significa essa frase? Significa o que? que eles pegaram isso daqui, formou um monte de bactérias $S$ vivas, que foram transformadas. Se eles pegassem esse tubo de ensaio e colocassem álcool, né? o que é que ele fazia, separava duas fases, o alcool separava duas fases. Separava uma fase líquida e um precipitado que retinha o princípio transformante.
Fornecer

evidências 
Como é que eles sabiam que retinha o princípio transformante?

Se eu pegar isso daqui e colocar em bactérias $R$, o que é que vai acontecer com essas bactérias $R$ ? Vão virar S, portanto, então esse princípio aqui, esse precipitado está transformando as bactérias $\mathrm{R}$ em $\mathrm{S}$, certo? Então esse é o princípio transformante, e não o líquido.. certo? então, eles, desssa maneira, colocando o álcool, ele conseguiu isolar uma grande quantidade de princípio transformante pra estudar, e aí o que é elews fizeram, página 2 , aí, na página seguinte.

$125 \quad 00: 31: 43 \quad P$

126 00:32:08 P

127 00:32:18 P

128 00:32:21 P

131

00:32:47 P

132 00:32:54 P

133 00:33:03 P

134 00:33:08 A

135

00:33:09

136

00:33:10 P

137

00:33:32 A

138 00:33:33 P

139 00:33:34 P

140

00:33:44 A

141 00:33:45 P

142

00:33:53 P

14

144 00:33:59 A 00:34:00 P

145 00:34:08 P

146 00:34:13 A

147 00:34:14 P
Ainda em 1944 eles isolaram grande quantidade desse princípio e foram testando, colocando um monte de enzimas pra verificar qual é a natureza desse princípio transformante. Então eles pegaram, João!

Então eles pegaram esse princípio transformante, colocaram amilase o que é que é amilase? hein?

Que substância? Faz o que?

hein Maria? Guarda isso.

O que é que faz a amilase? Hein?

Ninguém sabe?

Enzima que digere amido. Quando eu falo isso significa o que?

O que é que é digerir?

Quebrar.

Quebrar.

então se o princípio transformante fosse amido, amilase iria quebrar esse princípio transformante, ele iria continuar como princípio transformante? Não ele ia ser destruído. Certo? O que é que aconteceu aí? O que é que está escrito aí no texto? Ele continua como princípio tranformante. É amido?

Não.

Não.

Nesse princípio transfromante foi acrescentado protease. Proteases são enzimas que digerem? proteinas

proteinas. O que é que aconteceu? Continuou como princípio tranformante, são proteínas?

Não. Ribonucleases. Ribonucleases são enzimas que digerem.

ribonucleicos

ribonucleicos o que é que é ribonucleico? RNA, muito bem. Então.

Então, ribonucleases continuou com o princípio transformante?

$$
\text { Sim }
$$

Sim. É RNA? Não

Desoxirribonuclease. Enzima que digere o DNA,
Conferir

evidências

Conferir evidências 
então quebra o DNA. Perdeu o princípio

evidências

transformante. Então o princípio transformante é o

quê?

149 00:34:30 A DNA

150 00:34:31 P DNA. Certo? Então, conlusão: Quem tranformou a bactéria foi o DNA da outra bactéria. Essa é a conclusão.

$151 \quad$ 00:34:36 P Aí houve confusão se essse princípio tranformante estava contaminado ou não. Em 1952 é que eles conseguiram amostras bem puras desse princípio transformante e verificaram aí que era o DNA. Certo?

15

00:35:04 P Muito bom.

153 00:35:08 P Questão 2, questão dois não, experimento número dois.

$154 \quad$ 00:35:09 $\quad P \quad$ então tudo isso gente pra gente caminhar com a ideia

de que o DNA é o mterial hereditário, tá?

Aí, o que é que eles fizeram? A gente agora vai ver o material hereditário em vírus. $\mathrm{O}$ que são vírus bacteriófagos?

$156 \quad 00: 35: 29 \quad P$

Vírus bacteriófagos são vírus que atacam bactérias, tá? Então as bactérias também são atacadas por vírus. Né?

$157 \quad$ 00:35:39 $\quad P \quad$ Eu acho que o ano passado vocês deveram ter aprendido isso, né? Mas qual é o funcionamento de um vírus bactriófago? Eu tenho uma bactéria aqui. Certo? Você tem um vírus bacteriófago.

158 00:36:08 A Professora,

ela não ouve

$159 \quad$ 00:36:12 P Este é um vírus bacteriófago. O vírus, bacteriófago, ele é feito de DNA. Etão ele tem DNA aqui e é formado por uma cápsula de proteínas.

$160 \quad 00: 36: 36 \quad P$ Então, shhh

$161 \quad$ 00:36:43 $\quad P \quad$ Inclusive a discussão se vírus é ser vivo ou não porque ele não tem mais nenhuma outra organela celular.Então ele não tem membrana plasmática, ele não tem núcleo, ele não tem citoplasma ele não tem é (...) retículo endoplasmático, ele não tem mitocôndria, ele não tem absolutamente nada. Só tem DNA e essa cápsula protéica.Certo?

$162 \quad 00: 37: 07 \quad P$ E como ele faz? Ah (...) sabia-se que o vírus infecta a bactéria, então coloca alguma coisa dentro da bactéria. Esta coisa que ele coloca, que ou é o DNA ou são as proteínas, tem informação pra ele construir novos vírus, Ele constrói centenas de vírus novos e a bactéria, a célula explode. Certo? Então ele usa todo o mecanismo da célula da bactéria para sua reprodução, porque ele não tem nada lá dentro, só o DNA. Né? Então ele usa toda a estrutura da bactéria para a sua reprodução e até que a célula, até que ele produz centenas aí de vírus e explode, liberando outros vírus que vão infectar novas bactérias e assim é o modo de funcionamento do vírus, tá? Inclusive nas nossas células, nos vírus que infectam a gente.Tá?

$163 \quad$ 00:38:13 P $\quad$ O que será que entra e que tem a informação pra produzir novos vírus, será que é a proteína ou será que é o DNA? 


\begin{tabular}{|c|c|c|c|c|}
\hline 164 & $00: 38: 25$ & $\mathrm{P}$ & $\begin{array}{l}\text { Então, o que é que eles fizeram aí em 1952? Eles } \\
\text { marcaram o DNA com fósforo radioativo. Porque o } \\
\text { DNA tem fósforo, não tem? Então eles marcaram o } \\
\text { DNA com fósforo radioativo. Por quê? A } \\
\text { radioatividade é usada nos laboratórios, né, de } \\
\text { biologia molecular porque ela emite luz, então você } \\
\text { consegue identificar as substâncias aí, certo? Onde é } \\
\text { que estão, pra onde foram e tal. Então foi marcado } \\
\text { com fósforo radioativo. E a proteína tem enxofre e } \\
\text { não tem fosforo, foi marcada com enxofre radioativo. }\end{array}$ & \\
\hline 165 & $00: 39: 25$ & $\mathrm{P}$ & $\begin{array}{l}\text { Porque assim, marcando, eles poderiam ver o que é } \\
\text { que entra na célua da bactéria. E aí o que é que eles } \\
\text { encontraram? Eles encontraram, dentro da célula da } \\
\text { bactéria, o fósforo radioativo. Então eles } \\
\text { encontraram o fósforo radioativo. Conclusão: o que é } \\
\text { que entra na célula? }\end{array}$ & \\
\hline 166 & 00:40:00 & $P$ & o que é que entra na célula? & \\
\hline 167 & 00:40:03 & $\mathrm{P}$ & $\begin{array}{l}\text { o DNA. O DNA. E eles também centrifugaram ali a } \\
\text { mistura e viram que as cápsulas protéicas, o enxofre, } \\
\text { fica, não entra na célula das bactéria. Fica fora da } \\
\text { célula das bactérias e só entra o DNA. O que é que } \\
\text { eles concluíram? }\end{array}$ & \\
\hline 168 & $00: 40: 24$ & $P$ & $\begin{array}{l}\text { Que a partir dessa, do DNA é que o vírus vai fabricar } \\
\text { novos vírus idênticos ao original, certo? Tudo bem? }\end{array}$ & \\
\hline 169 & $00: 40: 46$ & $\mathrm{P}$ & $\begin{array}{l}\text { Agora eu pergunto pra vocês: por que é que esses } \\
\text { dois experimentos permitem afirmar que o DNA é } \\
\text { fonte da informação hereditáira, é o portador da } \\
\text { informação hereditária? }\end{array}$ & $\begin{array}{l}\text { Incitar } \\
\text { justificativa }\end{array}$ \\
\hline 170 & $00: 41: 10$ & $\mathrm{P}$ & $\begin{array}{l}\text { Né? Porque você tem ali dois resultados de dois } \\
\text { experimentos muito específicos, um com bactéria e } \\
\text { outro com vírus. Por que é que, sabendo que é o DNA } \\
\text { que tem o princípio transformante que transforma as } \\
\text { bactérias, faz com que ele seja o portador da } \\
\text { informação genética, da informação hereditária? e } \\
\text { por que é que esse experimento do vírus, junto com } \\
\text { o experimento da bactéria permite afirmar isso, } \\
\text { certo? }\end{array}$ & $\begin{array}{l}\text { Incitar } \\
\text { justificativa }\end{array}$ \\
\hline 171 & $00: 41: 40$ & $\mathrm{P}$ & Então eu vou colocar essa questão na lousa. & \\
\hline 172 & 00:42:09 & $P$ & Então copiem essas questões. & \\
\hline 173 & $00: 44: 15$ & $\mathrm{P}$ & $\begin{array}{l}\text { Anotem a questão, na aula que vem vamos fazer uma } \\
\text { pequena discussão em grupos e uma discussão } \\
\text { geralzona aí pra vocês produzirem um texto sobre } \\
\text { essa questão e me entregarem. } \\
\text { FIM DA AULA }\end{array}$ & \\
\hline
\end{tabular}

\begin{tabular}{|c|c|c|c|c|c|}
\hline Turno & Tempo & Pessoa & Falas & $\begin{array}{l}\text { Ações pró- } \\
\text { argumentação }\end{array}$ & Observações \\
\hline 1 & $00: 58: 42$ & & & & \\
\hline 2 & 00:59:32 & $\mathrm{P}$ & Pessoal! Bom dia! Atenção à chamada. & & \\
\hline 3 & 01:01:13 & $\mathrm{P}$ & Pessoal! Atenção, que a atividade começa agora. & & \\
\hline 4 & 01:01:19 & $\mathrm{P}$ & Pessoal! Podemos começar, Maria? & & \\
\hline 5 & 01:01:34 & $\mathrm{P}$ & $\begin{array}{l}\text { Pessoal, óh. Na aula passada, semana passada, vocês (...) } \\
\text { Shhh (...) vocês fizeram a discussão em grupo daquela } \\
\text { questão. Por que as conclusões dos experimentos (...) }\end{array}$ & & \\
\hline 6 & & A & Não. & & $\begin{array}{l}\text { Vários alunos } \\
\text { falam }\end{array}$ \\
\hline
\end{tabular}


7

A

Você (inaudível).

8

01:02:04

P

9

01:02:09 P

10

01:02:26 P

11

01:02:44 P

12

01:03:09 P

13

01:34:20 P

14

15

16

01:34:40 P

01:35:54 P

17

01:36:09 P

18

01:36:26 P

19

01:36:34 A

20

01:37:07 P

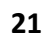

01:37:36 A

22

01:37:39 P

23

01:37:44 A

24

01:38:02 P

Beleza, lembrei. para nota, ok? organizar.

Fileiras. João começa. gente, rápido. experiências. significa o quê?

Se reproduz.

Codifica.
Então vocês vão fazer, nós discutimos os dois experimentos cujas conclusões levavam a gente a pensar que o DNA é o portador das informações hereditárias.

Qual é a atividade de hoje então? Vocês vão discutir essa questão que eu coloquei na lousa, né? Por que as conclusões dos experimentos 1 e 2 dessa ficha, né? Permitem afirmar que o DNA é o portador das informações hereditárias.

Então vocês, nós vamos ter duas etapas. Nós vamos fazer a discussão em pequenos grupos. Depois a gente vai abrir a discussão pra colocar o que cada grupo discutiu e aí vocês vão individualmente ter a resposta, fazer a resposta para esta questão. Tá? Pra entregar,

Então, grupos de no máximo 4 alunos, podem se

Calma professora, a gente vai terminar de escrever.

Então roda, vamos lá.

Bom pessoal, quero que cada grupo exponha rapidamente pra gente poder ter a discussão, né? É (...)

Como cada experimento pode ajudar a gente a dizer que o DNA é o portador das informações hereditárias.

Meninas aqui, então, vamos começar por aqui. (...) Vai

A gente conversou e a gente achou (...) não (...) nos dois experimentos eles chegavam (inaudível) que várias substâncias que podem ser supostas (...) que podem conter o material genético e aí eles chegam sempre ao mesmo resultado, que é o único que pode ser o material genético é o DNA (...) tipo, por exclusão mesmo, né? Mas, tá? E meninas, o que significa isso, de ser o material, o DNA o material hereditário, né? Por que é que (inaudível) deles testarem que o material responsável ali pelos experimentos, pelas alterações, pelas mudanças observadas nos experimentos era o DNA. O que é que significa essa conclusão, de que são o material hereditário?

Na verdade a gente não (inaudível).

Não, tudo bem. Pra ajudar a pensar, né?

E aí, (inaudível) depois do (...), como o João falou, que o DNA era o princípio transformante (inaudível) pelas

E isso significa o quê? Ser o princípio transformante

Se reproduz, (inaudível) bactéria?

O DNA do, o DNA do, da S morta pelo calor eles ficou intacto e in vitro, né? Que era no tubinho de ensaio, eles simultaneamente, negando e cortando a fala da professora Muito barulho na sala provocado pelo erro da professora. Ainda muito barulho na sala

Bate palmas para chamar a atenção dos alunos
Encorajar a ouvir 
colocaram $\mathrm{S}$ mortas com $\mathrm{R}$ vivas (...) só os DNAs né? $\mathrm{O}$ DNA da S morta (...) como se diz? Ele modificou o material genético das $R$ vivas e transformou a $R$ vivas em $S$ vivas. E ela começou a se reproduzir, é (...) que acabou infectando os camundongos e mataram eles de pneumonia.

Isso. Então essa é a historinha lá das bactérias, né? As bactérias, eu passei em alguns grupos contando um pouco isso. A gente (...) como é que o ser humano passa a informação para outra geração? Oi?

Através da reprodução sexuada. Isso significa dizer o quê? Que a informação ela passa de uma geração pra outra e ela vai estar em que células? Nos gametas.

Nos gametas. Óvulos e espermatozoides, certo?

Que nojo.

Aluno tirando sarro

Nas bactérias, (...) a forma das bactérias se reproduzirem é pela divisão celular, quando elas se dividem, elas transmitem essa informação para as próximas gerações. Mas, além disso, elas tem a capacidade de (...) captar DNA do ambiente, no caso lá o DNA da bactéria $\mathrm{S}$ morta. Ou mesmo de duas bactérias vivas. Então, isso significaria o seguinte: era como se eu pegasse encostasse aqui no João, ele me passasse um pedaço do seu DNA e de repente eu virasse loira, né? Modificaria a minha característica, né? Seria uma maneira mais fácil do que pintar o cabelo. (inaudível)

Então, (...) ou vai a parte ruim, né?

Então, as bactérias elas tem essa propriedade de captar DNA de trocar DNA entre as bactérias adultas. Isso foi muito útil lá na origem da vida porque isso possibilitou que surgissem diversidade, que aumentasse a diversidade das bactérias. Então no caso da bactéria $\mathrm{R}$ e $S$ houve modificação na estrutura física da bactéria? Houve ou não houve? Não?

Qual é a diferença entre a $S$ e R?

Cápsula.

Além de causar a pneumonia ou não causar.

A cápsula de (...) a proteção da cápsula de carboidrato.

Elas têm uma cápsula de carboidrato em volta delas, por isso é que elas causam pneumonia. Por que como elas são resistentes por causa dessa capa, essa cápsula acaba servindo como proteção. Que vai fazer com q ela seja mais resistente no corpo do camundongo. As células do camundongo não conseguem destruir a bactéria q tem essa cápsula. Por isso é: quem tem a cápsula é que consegue se reproduzir no corpo do camundongo, causando a pneumonia, os sintomas da pneumonia, certo?

Então, o q é q aconteceu lá no princípio transformante? A bactéria $R$ pegou o DNA da bactéria $S$ e o que é que aconteceu com ela?
Fornecer evidências
Algum barulho na sala causado pela explicação de como pegar a característica Comenta a fala anterior de um aluno

Não é ouvido pela professora 


\begin{tabular}{|c|c|c|c|c|c|}
\hline 46 & $01: 41: 57$ & A & Se transformou (...) & & \\
\hline 47 & 01:47:59 & $P$ & Se transformou em R. e o que isso significa? & & \\
\hline 48 & 01:42:02 & A & Ela passou a produzir (...) & & \\
\hline 49 & 01:42:03 & $\mathrm{P}$ & $\begin{array}{l}\text { Ela passou a produzir (...) ela não produzia, ela passou a } \\
\text { produzir a cápsula de carboidrato, certo? Então o DNA } \\
\text { modificou as características da bactéria? }\end{array}$ & & \\
\hline 50 & 01:42:13 & $\mathrm{P}$ & $\begin{array}{l}\text { Foi o DNA que modificou a estrutura da bactéria, certo? } \\
\text { Além disso, quando elas se reproduziram, o que é que } \\
\text { aconteceu com essa (...) com as bactérias filhas? Como é } \\
\text { que eram essas bactérias filhas? }\end{array}$ & & \\
\hline 51 & & A & (inaudível) & & $\begin{array}{l}\text { Muitos alunos } \\
\text { falam juntos }\end{array}$ \\
\hline 52 & $01: 42: 29$ & $\mathrm{P}$ & $\begin{array}{l}\text { Iguais a que foi modificada (...) a que foi transformada. } \\
\text { As filhas ficaram também S ou R? }\end{array}$ & & \\
\hline 53 & 01:42:38 & A & S. & & $\begin{array}{l}\text { Vários alunos } \\
\text { respondem juntos }\end{array}$ \\
\hline 54 & $01: 42: 38$ & $\mathrm{P}$ & S. & & \\
\hline 55 & 01:42:41 & $\mathrm{P}$ & $\begin{array}{l}\text { E isso significa dizer, (...) então quem determinou essas } \\
\text { características, tanto da } S \text {, quanto das filhas da S? }\end{array}$ & & \\
\hline 56 & $01: 42: 53$ & A & O DNA. & & $\begin{array}{l}\text { Alguns alunos } \\
\text { respondem }\end{array}$ \\
\hline 57 & $01: 42: 54$ & $\mathrm{P}$ & O DNA, tudo bem? & & \\
\hline 58 & 01:42:58 & $\mathrm{P}$ & $\begin{array}{l}\text { E o segundo experimento? Como é que o segundo } \\
\text { experimento também pode dizer pra gente que é o DNA } \\
\text { que contém a informação hereditária? }\end{array}$ & $\begin{array}{l}\text { Conferir } \\
\text { evidências }\end{array}$ & \\
\hline 59 & 01:43:09 & A & (inaudível) conseguiu entrar na bactéria. & & \\
\hline 60 & 01:43:11 & $\mathrm{P}$ & Como só o DNA entrou na bactéria. & $\begin{array}{l}\text { Fornecer } \\
\text { evidências }\end{array}$ & \\
\hline 61 & 01:43:13 & A & (Inaudível) vírus completos (Inaudível). & & \\
\hline 62 & $01: 43: 23$ & $\mathrm{P}$ & $\begin{array}{l}\text { Ele reproduziu vários vírus completos. Então o que } \\
\text { aquele DNA tinha? }\end{array}$ & $\begin{array}{l}\text { Fornecer } \\
\text { evidências }\end{array}$ & \\
\hline 63 & 01:43:30 & A & (Inaudível) & & $\begin{array}{l}\text { Alguns alunos } \\
\text { falam baixo }\end{array}$ \\
\hline 64 & 01:43:31 & $\mathrm{P}$ & A informação para produzir esses novos (...) Fala João. & & \\
\hline 65 & $01: 43: 36$ & A & (Inaudível) & & \\
\hline 66 & 01:43:39 & $\mathrm{P}$ & $\begin{array}{l}\text { Tá, mas então repete, vamos reelaborar porque quando } \\
\text { você fala, você fala em outras palavras. (Inaudível) em } \\
\text { cima delas. }\end{array}$ & & \\
\hline 67 & 01:43:50 & A & Ele injetava o DNA na célula (...) & & \\
\hline 68 & 01:43:52 & $\mathrm{P}$ & Shh $(\ldots)$ ow & & \\
\hline 69 & 01:43:53 & A & $\begin{array}{l}\text { Daí a célula foi se reproduzindo com esse DNA (...) foi } \\
\text { isso que eu entendi. }\end{array}$ & & \\
\hline 70 & 01:44:02 & $\mathrm{P}$ & $\begin{array}{l}\text { Tá. Não foi a célula em si... O DNA entrou e aí utilizando } \\
\text { lá, as enzimas, a maquinaria da célula da bactéria } \\
\text { formou-se novos vírus. Idênticos ao original, então } \\
\text { houve o quê? Uma reprodução do vírus, né? Como é (...) } \\
\text { da onde veio a informação para a construção desses } \\
\text { novos vírus? }\end{array}$ & $\begin{array}{l}\text { Conferir } \\
\text { evidências }\end{array}$ & \\
\hline 71 & 01:44:29 & A & DNA do vírus. & & \\
\hline 72 & 01:44:30 & $\mathrm{P}$ & $\begin{array}{l}\text { Do próprio DNA do Vírus, que aí (...) eles marcando eles } \\
\text { conseguiram seguir e viram que só o DNA entrava e não } \\
\text { as proteínas, né? }\end{array}$ & $\begin{array}{l}\text { Fornecer } \\
\text { evidências }\end{array}$ & \\
\hline 73 & 01:44:39 & $\mathrm{P}$ & $\begin{array}{l}\text { Então, nos dois experimentos o que é que aconteceu (...) } \\
\text { nos dois experimentos aí? Qual é o resultado? }\end{array}$ & & \\
\hline 74 & 01:44:50 & A & Que o DNA transforma (Inaudível). & & \\
\hline 75 & $01: 44: 54$ & $\mathrm{P}$ & Por quê? & & \\
\hline 76 & $01: 44: 55$ & A & Porque ele faz (Inaudível). & & \\
\hline 77 & 01:44:56 & $P$ & Responsável pelo quê? & & \\
\hline 78 & & A & (Inaudível) & & \\
\hline
\end{tabular}




\begin{tabular}{|c|c|c|c|c|c|}
\hline 79 & 01:45:02 & $\mathrm{P}$ & $\begin{array}{l}\text { Que a gente pode ver lá (...) nos experimentos (...) como } \\
\text { o quê? }\end{array}$ & & \\
\hline 80 & $01: 45: 13$ & & $\begin{array}{l}\text { Isso é uma afirmação que a gente enxerga nos } \\
\text { experimentos? }\end{array}$ & & \\
\hline 81 & $01: 45: 16$ & A & É. & & \\
\hline 82 & $01: 45: 18$ & $\mathrm{P}$ & É? & & \\
\hline 83 & 01:45:19 & $\mathrm{P}$ & Que o DNA tem a informação hereditária? & & \\
\hline 84 & $01: 45: 21$ & A & Não, mas que a gente tira (...) da conclusão. & & \\
\hline 85 & $01: 45: 23$ & $\mathrm{P}$ & $\begin{array}{l}\text { Que a gente tira a partir das conclusões dos } \\
\text { experimentos. Quais conclusões? }\end{array}$ & & \\
\hline 86 & $01: 45: 29$ & A & Que o DNA tem capacidade de transformar (...) & & $\begin{array}{l}\text { Professora não } \\
\text { escuta esse aluno }\end{array}$ \\
\hline 87 & 01:45:31 & $\mathrm{P}$ & Oi? & & \\
\hline 88 & 01:45:35 & A & Várias substâncias foram testadas, só o DNA poderia (...) & & \\
\hline 89 & $01: 45: 38$ & $\mathrm{P}$ & $\begin{array}{l}\text { Várias substâncias foram testadas, só o DNA (...) e era } \\
\text { DNA, né? Pelos testes. Sobrou essa opção do DNA, mas } \\
\text { isso era pra ver qual era a substância. O que é que } \\
\text { aconteceu de importante nos experimentos que } \\
\text { permitem a gente concluir que o DNA tem o material, } \\
\text { tem a informação hereditária? } \\
\text { (Inaudível) }\end{array}$ & $\begin{array}{l}\text { Fornecer } \\
\text { evidências }\end{array}$ & \\
\hline 91 & 01:46:04 & $\mathrm{P}$ & $\begin{array}{l}\text { Se reproduziram (...) seres lá se reproduziram, passaram } \\
\text { essa informação pro seu descendente e conseguiram } \\
\text { detectar que, qual substância do ser vivo era } \\
\text { responsável por isso? }\end{array}$ & & \\
\hline 92 & $01: 46: 20$ & $\mathrm{P}$ & Era o DNA. & & \\
\hline 93 & $01: 46: 22$ & $\mathrm{P}$ & Tudo bem? Dá pra escrever esse texto? & & \\
\hline 94 & & A & Sim, não. & & $\begin{array}{l}\text { Alguns alunos } \\
\text { falam junto }\end{array}$ \\
\hline 95 & $01: 46: 28$ & $\mathrm{P}$ & A resposta a essa questão. & & \\
\hline 96 & $01: 46: 32$ & $\mathrm{P}$ & Relacionando essas coisas todas? & & \\
\hline 97 & $01: 46: 35$ & $\mathrm{P}$ & Pra quarta-feira. & & \\
\hline 98 & $01: 46: 40$ & $\mathrm{P}$ & Oi? & & \\
\hline 99 & 01:46:44 & $\mathrm{P}$ & $\begin{array}{l}\text { As substâncias testadas João, ali por exemplo, naquele } \\
\text { experimento o que é que eles fazem? Óh. Importante } \\
\text { aqui pra todos. }\end{array}$ & & $\begin{array}{l}\text { A professora } \\
\text { chama a atenção } \\
\text { da sala, pois } \\
\text { começa a haver } \\
\text { dispersão. }\end{array}$ \\
\hline 100 & & A & (Inaudível) & & \\
\hline 101 & $01: 46: 58$ & $\mathrm{P}$ & Então, no experimento (...) shh (...) ow & & \\
\hline 103 & 01:47:03 & A & $\begin{array}{l}\text { No experimento das bactérias, o que é que eles fazem? } \\
\text { Primeiro eles tem um resultado de que tem } \\
\text { transformação bacteriana, só que eles não sabem o que } \\
\text { causou a transformação da bactéria. De R pra S. Aí eles } \\
\text { conseguem produzir muito desse princípio } \\
\text { transformante, dessa substância que causa } \\
\text { transformação, e vão testar o que é que é. Aí eles } \\
\text { colocam enzimas que digerem amido, se fosse amido, o } \\
\text { que é que aconteceria? Perderia o princípio, né? } \\
\text { (Inaudível) }\end{array}$ & & \\
\hline 104 & $01: 47: 38$ & $\mathrm{P}$ & $\begin{array}{l}\text { Tem, eles testaram um monte de coisa, eu dei como } \\
\text { exemplo, tá? Daí só aconteceu a modificação com o (...) } \\
\text { colocou a enzima que digere o DNA. Tá? } \\
\text { (Inaudível) }\end{array}$ & & \\
\hline 106 & 01:47:59 & $\mathrm{P}$ & Não dessa forma. Aí a bactéria (Inaudível) a partir disso. & & \\
\hline 107 & 01:48:10 & $\mathrm{P}$ & $\begin{array}{l}\text { Pessoal, outra coisa importante. Essa lição é para quarta- } \\
\text { feira e quarta-feira da outra semana, dia 07. (...) la ser } \\
\text { segunda feira, tá? Mas aí a outra sala pediu pra ser } \\
\text { quarta feira, eu até deixei, mas só pode ser segunda ou }\end{array}$ & & \\
\hline
\end{tabular}


quarta. É a prova, mas pra vocês é até bom porque (...),

tá?

108

(Inaudível)

$109 \quad 01: 48: 37 \quad P$

Quarta-feira da outra semana (Inaudível).

$110 \quad 01: 48: 47 \quad P$

Pessoal, quem quiser anotar isso daqui, mas vão

colocando as carteiras em fileiras.

FIM DA AULA 


\section{Apêndice 04 - Argumentos da professora}

\begin{tabular}{|c|c|c|c|c|c|c|}
\hline Categoria & Aula & Linha & Tempo & Pessoa & Fala & Argumento \\
\hline \multirow[t]{9}{*}{1} & 51 & 38 & & $P$ & $\begin{array}{l}\text { Não, mas a questão é (...) A determinação, tem o Y é masculino. Não tem, tanto é que lembra aquele que só } \\
\text { tem um } X \text { ? É feminino. Só que também é a Síndrome de Turner que é o X0. Tem o } X \text { e não tem o outro } X \text {. }\end{array}$ & $\begin{array}{l}\text { Dado que não tem Y e só tem um } \\
\mathrm{X} \text {, já que quem tem } \mathrm{Y} \text { é } \\
\text { masculino, assim, é feminino. }\end{array}$ \\
\hline & \multirow[t]{4}{*}{511} & 22 & $00: 02: 16$ & $P$ & Dado que tem Dois $\mathrm{X}$ e um $\mathrm{Y}$ & \multirow{4}{*}{$\begin{array}{l}\text { Dado que tem dois } \mathrm{X} \text { e um } \mathrm{Y}, \\
\text { assim, a doença é Klinefelter. }\end{array}$} \\
\hline & & 24 & $00: 02: 21$ & $P$ & Assim, a doença é & \\
\hline & & \multirow[t]{2}{*}{26} & \multirow[t]{2}{*}{$00: 02: 25$} & \multirow[t]{2}{*}{$P$} & Klinefelter! & \\
\hline & & & & & Então um dos cariótipos era Síndrome de Klinefelter. Tinha dois $\mathrm{X}$ e um $\mathrm{Y}$, né? & \\
\hline & $5 \mathrm{II}$ & 29 & 00:02:39 & $\mathrm{P}$ & $\begin{array}{l}\text { Síndrome de Down! Tinha um que era Síndrome de Down, que tinha três cromossomos 21, estava sobrando } \\
\text { um! }\end{array}$ & $\begin{array}{l}\text { Dado que tinha três } \\
\text { cromossomos } 21 \text {, estava } \\
\text { sobrando um [cromossomo], } \\
\text { assim, tinha uma que era } \\
\text { síndrome de Down. }\end{array}$ \\
\hline & \multirow[t]{3}{*}{511} & 30 & $00: 02: 46$ & $P$ & $\begin{array}{l}\text { Então, realmente! Imagina uma das primeiras pesquisas ali, quando eles fizeram, né (...) esses cariótipos, } \\
\text { "Ah, nossa, está sobrando um cromossomo". E aí eles foram pesquisar e identificar o que era isso. }\end{array}$ & \multirow{3}{*}{$\begin{array}{l}\text { Dado que os pesquisadores } \\
\text { verificaram que todos tinham } \\
\text { algum problema, tinham esse } \\
\text { cromossomo a mais, assim, esses } \\
\text { cromossomos que vocês } \\
\text { identificaram podem indicar a } \\
\text { síndrome }\end{array}$} \\
\hline & & 33 & 00:03:12 & $P$ & $\begin{array}{l}\text { Eles foram pesquisar alguns pacientes e aí eles verificaram que todos tinham algum problema, tinham esse } \\
\text { cromossomo a mais, tá? }\end{array}$ & \\
\hline & & 34 & 00:03:20 & $P$ & Então esses cromossomos a mais que vocês identificaram, pode ser a síndrome. & \\
\hline \multirow[t]{5}{*}{2} & 51 & 81 & 00:20:09 & $P$ & E chamou, como essa substância era uma substância ácida, chamou de ácido nucléico, certo? & $\begin{array}{l}\text { Dado que a substância era ácida, } \\
\text { assim, foi chamada de ácido } \\
\text { nucléico. }\end{array}$ \\
\hline & $5 \mathrm{II}$ & 62 & 00:02:38 & $\mathrm{P}$ & $\begin{array}{l}\text { Então, em } 1879 \text { [ou1859?], o pesquisador John Richards identificou em núcleos de glóbulos brancos um } \\
\text { composto de natureza ácida, rico em fósforo e em nitrogênio, desprovido de enxofre e resistente à ação da } \\
\text { pepsina, enzima que digere proteínas. E chamou esse composto de nucleína, porque ele estava presente no } \\
\text { núcleo. }\end{array}$ & $\begin{array}{l}\text { Dado que o composto estava } \\
\text { presente no núcleo, assim, o } \\
\text { pesquisador o chamou de } \\
\text { nucleína. }\end{array}$ \\
\hline & \multirow[t]{3}{*}{$5 \mathrm{II}$} & 92 & 00:05:53 & $\mathrm{P}$ & É (...) e rico em fósforo e nitrogênio, tá? & \multirow{3}{*}{$\begin{array}{l}\text { Dado que não era proteína, já } \\
\text { que a substância tem fósforo e é } \\
\text { ácida, assim, o pesquisador deu o } \\
\text { nome de nucleína. }\end{array}$} \\
\hline & & 93 & & $P$ & As proteínas têm nitrogênio, mas não têm fósforo. E essa substância tem fósforo, tá? & \\
\hline & & 94 & & $P$ & $\begin{array}{l}\text { Além disso, é uma substância ácida. Então, com essa, com os experimentos bioquímicos, eles perceberam, } \\
\text { ele começou a perceber o que tinha e o que não tinha nessa substância. Como não era uma proteína, ele } \\
\text { deu um novo nome aí de nucleína, tá? }\end{array}$ & \\
\hline
\end{tabular}




\begin{tabular}{|c|c|c|c|c|c|c|}
\hline & 511 & 96 & 00:06:52 & $P$ & $\begin{array}{l}\text { Só que, vinte anos depois, na letra B, 1889(?) Richard Altmann é (...) confirmou a natureza ácida desse } \\
\text { composto. Repetiu esses experimentos e verificou realmente que era diferente das proteínas. E, como ele } \\
\text { era ácido, chamou de ácido nucléico, então ainda é um nome genérico, sem saber muito bem a função, né? }\end{array}$ & $\begin{array}{l}\text { Dado que o composto era ácido, } \\
\text { assim, deu o nome de ácido } \\
\text { nucléico. }\end{array}$ \\
\hline Categoria & Aula & Linha & Tempo & Pessoa & Fala & Argumento \\
\hline \multirow[t]{4}{*}{3} & 51 & 53 & & $P$ & $\begin{array}{l}\text { A informação era quê? Eles achavam que eram as proteínas que tinham as informações hereditárias. Eles } \\
\text { começaram a dar muita importância pras proteínas porque tinha proteínas em todos os lugares das células, } \\
\text { né? }\end{array}$ & $\begin{array}{l}\text { Dado que tinha proteínas em } \\
\text { todos os lugares das células, } \\
\text { assim, eles começaram a dar } \\
\text { muita importância pras } \\
\text { proteínas. }\end{array}$ \\
\hline & 51 & 244 & & & $\begin{array}{l}\text { As proteínas estavam em todos os lugares das células, compondo várias estruturas, participando de várias } \\
\text { reações químicas, então, por que não elas serem também as portadoras das informações hereditárias? Né? }\end{array}$ & $\begin{array}{l}\text { Dado que as proteínas estavam } \\
\text { em todos os lugares das células, } \\
\text { que compunham várias } \\
\text { estruturas e participavam de } \\
\text { várias reações químicas, assim, } \\
\text { porque não serem portadoras } \\
\text { das informações genéticas? }\end{array}$ \\
\hline & 511 & 67 & & $P$ & $\begin{array}{l}\text { Elas fazem tudo, elas estão em todas as estruturas celulares, então, talvez também sejam as proteínas as } \\
\text { responsáveis por guardar a informação hereditária, a informação que passa (...) de uma geração para outra, } \\
\text { né? }\end{array}$ & $\begin{array}{l}\text { Dado que as proteínas estão em } \\
\text { todas as estruturas celulares, } \\
\text { então, talvez, as proteínas sejam } \\
\text { responsáveis por guardar a } \\
\text { informação hereditária. }\end{array}$ \\
\hline & $7 \|$ & 60 & 00:13:33 & $P$ & $\begin{array}{l}\text { Então, naquela época, final do século XIX começo do século XX, eles já sabiam muito sobre as protéínas. Eles } \\
\text { encontravam proteínas em todas as partes das células. Então, do que é que é feita a membrana plasmática, } \\
\text { por exemplo, ou a membrana do núcleo? Lembram? Lipídios e proteínas, então a proteína está lá. Qualquer } \\
\text { reação química que acontece na célula depende de enzimas e enzimas são proteínas. Então as enzimas } \\
\text { participam de todos os processos celulares, de todos. E existem milhares de tipos diferentes de proteínas. } \\
\text { Então eles estavam achando naquela época, final do século dezenove, começo do século vinte, que porque } \\
\text { não as proteínas, que fazem parte de toda célula, que fazem parte de todas as reações químicas que } \\
\text { acontecem na célula. Por que não as proteínas que contém a informação genética, a informação } \\
\text { hereditária? A informação que determina as características daquela célula e que determina a passagem da } \\
\text { informação de uma célula para a outra, ou de um ser vivo para o outro. }\end{array}$ & $\begin{array}{l}\text { Dado que eles encontravam } \\
\text { proteínas em todas as partes das } \\
\text { células, já que a membrana é } \\
\text { formada de proteínas, as reações } \\
\text { químicas dependem de } \\
\text { proteínas, existem milhares de } \\
\text { tipos de proteínas, assim, por } \\
\text { que não as proteínas conterem a } \\
\text { informação hereditária? }\end{array}$ \\
\hline
\end{tabular}




\begin{tabular}{|c|c|c|c|c|c|c|}
\hline Categoria & Aula & Linha & Tempo & Pessoa & Fala & Argumento \\
\hline \multirow[t]{10}{*}{4} & 51 & 58 & 00:17:01 & $P$ & $\begin{array}{l}\text { Que informações desse parágrafo que permitem a gente concluir que essa substância é diferente de } \\
\text { proteína, que não é uma proteína? }\end{array}$ & $\begin{array}{l}\text { Dadas a composição química e a } \\
\text { resistência da substância à } \\
\text { pepsina, assim, podemos concluir } \\
\text { que essa substância é diferente } \\
\text { de proteína. }\end{array}$ \\
\hline & \multirow[t]{2}{*}{51} & 60 & & $P$ & $\begin{array}{l}\text { A composição química e a resistência à pepsina. Então vamos primeiro analisar a resistência à ação da } \\
\text { pepsina. O que é que é a pepsina? }\end{array}$ & \multirow{2}{*}{$\begin{array}{l}\text { Dado que a composição química } \\
\text { é ácida, rico em fósforo, com } \\
\text { nitrogênio, desprovida de } \\
\text { enxofre, já que proteínas têm } \\
\text { pouco fósforo e são ricas em } \\
\text { enxofre. Assim, o composto é } \\
\text { diferente de proteína. }\end{array}$} \\
\hline & & 77 & & $P$ & $\begin{array}{l}\text { Então isso é um ponto. Outro ponto que a Maria falou lá é a composição química. Composição química } \\
\text { ácida, rica em fósforo. Proteína tem pouco fósforo, não tem fósforo. Tem nitrogênio, mas fósforo é pobre } \\
\text { em fósforo. E essa substância tinha fósforo. Desprovida de enxofre e proteínas geralmente tem bastante (?) } \\
\text { enxofre. Então também a composição química, os elementos químicos encontrados nessa substância são } \\
\text { diferentes (?) das proteínas, mesmo assim, muitos pesquisadores não acreditaram nesse (inaudível) Richard. } \\
\text { E falaram: "não, isso são proteínas que estão contaminadas com grupos fosfatos, né?" }\end{array}$ & \\
\hline & \multirow[t]{5}{*}{511} & 72 & 00:04:30 & $P$ & $\begin{array}{l}\text { O que é que está escrito aí na letra A, que me permite afirmar que essas substâncias presentes no núcleo, } \\
\text { que, por causa disso ele chamou de nucleína. O que é que me permite dizer que essa substância não é uma } \\
\text { proteína? }\end{array}$ & \multirow{5}{*}{$\begin{array}{l}\text { Dado que a substância presente } \\
\text { no núcleo resistiu à ação da } \\
\text { pepsina, assim, posso dizer que a } \\
\text { substância não é proteína, já que } \\
\text { a pepsina digere proteínas. }\end{array}$} \\
\hline & & 73 & $00: 04: 47$ & A & Indecifrável & \\
\hline & & 74 & 00:04:48 & $P$ & Ela resistiu à pepsina. E a pepsina o que é? & \\
\hline & & 75 & & A & Indecifrável & \\
\hline & & 76 & $00: 04: 54$ & $P$ & $\begin{array}{l}\text { Ela digere proteína. Então, se fosse uma proteína, quando eu colocasse (...) quando eu colocasse essa } \\
\text { substância em contato com a pepsina, o que é que iria acontecer com essa proteína, João? }\end{array}$ & \\
\hline & $5 I I$ & 89 & 00:05:36 & $P$ & Então, o que é que acontece? Resistente à pepsina, então não era proteína. Além disso, desprovido de (...) & $\begin{array}{l}\text { Dado que era resistente à } \\
\text { pepsina, assim, não era proteína. }\end{array}$ \\
\hline & 511 & 91 & 00:05:45 & $P$ & Enxofre! Em geral, as proteínas também, muitas proteínas têm enxofre na sua composição, Maria. & $\begin{array}{l}\text { Dado que o composto era } \\
\text { desprovido de enxofre, já que } \\
\text { muitas proteínas têm enxofre na } \\
\text { sua composição, assim, não era } \\
\text { proteína. }\end{array}$ \\
\hline Categoria & Aula & Linha & Tempo & Pessoa & Fala & Argumento \\
\hline \multirow[t]{2}{*}{5} & \multirow[t]{2}{*}{51} & 119 & & $P$ & $\begin{array}{l}\text { Nucleotídeo, que por sua vez, são formadas por: base nitrogenada, um carboidrato, que é chamado de } \\
\text { pentose (inaudível) e um fosfato. Se esse carboidrato for a desoxirribose, é DNA ou RNA? }\end{array}$ & $\begin{array}{l}\text { Dado que o carboidrato é } \\
\text { desoxirribose, assim, é DNA. }\end{array}$ \\
\hline & & 120 & & A & DNA & $\begin{array}{l}\text { Dado que o carboidrato é ribose, } \\
\text { assim, é RNA. }\end{array}$ \\
\hline
\end{tabular}




\begin{tabular}{|c|c|c|c|c|c|}
\hline & 121 & & $P$ & DNA. Se for uma ribose? & \multirow{4}{*}{$\begin{array}{l}\text { Dado que a base nitrogenada é a } \\
\text { adenina, assim, pode ser RNA ou } \\
\text { DNA. }\end{array}$} \\
\hline & 122 & & A & RNA & \\
\hline & 123 & & $P$ & RNA. Se essa base nitrogenada for uma adenina? & \\
\hline & 124 & & $P$ & Pode ser um dos dois. Tem que ver aqui (inaudível) & \\
\hline 51 & 156 & & & $\begin{array}{l}\text { Então, já que era um modelo helicoidal, parecia que o DNA tinha duas cadeias. Duas cadeias de } \\
\text { nucleotídeos. Ligadas pelas bases nitrogenadas. De maneira complementar. Sempre A se ligando com T, } \\
\text { sempre C se ligando com G. Dessa forma aqui. }\end{array}$ & $\begin{array}{l}\text { Dado que era um modelo } \\
\text { helicoidal, assim, parecia que o } \\
\text { DNA tinha duas cadeias. }\end{array}$ \\
\hline \multirow[t]{3}{*}{$5 \mathrm{II}$} & 99 & 00:07:59 & $\mathrm{P}$ & Com cinco carbonos, tá? Então, tinha essas bases nitrogenadas, bases nitrogenadas, contém muito o quê? & \multirow[t]{3}{*}{$\begin{array}{l}\text { Dado que tem muito nitrogênio, } \\
\text { assim, chama base nitrogenada. }\end{array}$} \\
\hline & 100 & & A & Indecifrável & \\
\hline & 101 & 00:08:10 & & Nitrogênio! Né? Então tudo se confirmando aquela primeira pesquisa (indecifrável) & \\
\hline $5 \mathrm{II}$ & 115 & & $\mathrm{P}$ & $\begin{array}{l}\text { Por que desoxirribose? "oxi" de oxigênio, "des" de sem. Então, a desoxirribose tem um oxigênio a menos } \\
\text { que a ribose, certo? }\end{array}$ & $\begin{array}{l}\text { Dado que a desoxirribose indica } \\
\text { uma ribose sem oxigênio, assim, } \\
\text { a desoxirribose tem um oxigênio } \\
\text { a menos que a ribose. - } \\
\text { Tautológico }\end{array}$ \\
\hline $5 \mathrm{II}$ & 168 & 00:00:00 & & $\begin{array}{l}\text { [começa nomeio da fala da professora](...) né? Normalmente fala: o DNA é uma estrutura dupla fita. Porque } \\
\text { ela tem essas duas cadeias ne nucleotídeo. Continua aqui, né?Âh (...) }\end{array}$ & $\begin{array}{l}\text { Dado que tem duas cadeias de } \\
\text { nucleotídeos, assim, o DNA é } \\
\text { uma estrutura dupla fita. }\end{array}$ \\
\hline \multirow[t]{3}{*}{$5 \mathrm{II}$} & 142 & 00:16:37 & $\mathrm{P}$ & DNA! Se for formado por ribose, é DNA ou RNA? & \multirow{3}{*}{$\begin{array}{l}\text { Dado que é formado por ribose, } \\
\text { assim, é RNA. }\end{array}$} \\
\hline & 143 & & A & RNA & \\
\hline & 144 & $00: 16: 42$ & $P$ & RNA! Certo? & \\
\hline $5 \mathrm{II}$ & 162 & & $P$ & $\begin{array}{l}\text { Ela estava muito perto, eles estavam muito perto de chegar nessa estrutura do DNA. Essa forma helicoidal } \\
\text { mostrou o que? Que talvez as bases nitrogenadas se ligassem entre si. E os carboidratos e grupos fosfatos } \\
\text { ficassem circulando aí em volta das bases nitrogenadas. }\end{array}$ & $\begin{array}{l}\text { Dado que o DNA tem estrutura } \\
\text { helicoidal, assim, talvez, as bases } \\
\text { nitrogenadas estejam ligadas } \\
\text { entre si e os carboidratos e } \\
\text { grupos fosfatos fiquem } \\
\text { circulando em volta das bases } \\
\text { nitrogenadas. }\end{array}$ \\
\hline \multirow[t]{2}{*}{$7 \mid I$} & \multirow[t]{2}{*}{42} & \multirow[t]{2}{*}{ 00:08:15 } & \multirow[t]{2}{*}{$\mathrm{P}$} & \multirow{2}{*}{$\begin{array}{l}\text { Isso é o nucleotídeo, tá? Essa estrutura é o nucleotídeo. Que é um fosfato, ligado com um açúcar, ligado } \\
\text { com uma base nitrogenada. Isso serve tanto pro DNA como pro RNA, tá? Só que aí você tem: se for DNA } \\
\text { qual é o açúcar? Desoxirribose. Se for RNA, qual é o açúcar? Ribose. }\end{array}$} & $\begin{array}{l}\text { Dado que é DNA, assim, o açúcar } \\
\text { é desoxirribose. }\end{array}$ \\
\hline & & & & & $\begin{array}{l}\text { Dado que é DNA, assim, o açúcar } \\
\text { é ribose. }\end{array}$ \\
\hline
\end{tabular}




\begin{tabular}{|c|c|c|c|c|c|c|}
\hline Categoria & Aula & Linha & Tempo & Pessoa & Fala & Argumento \\
\hline 6 & $5 \mathrm{II}$ & 133 & & $P$ & $\begin{array}{l}\text { Então vários aminoácidos ligados formam uma proteína. Assim como carboidratos. São uma molécula } \\
\text { grande, uma macromolécula, são polissacarídeos, são formados por, pela união de várias subunidades, quais } \\
\text { são as subunidades dos carboidratos? }\end{array}$ & $\begin{array}{l}\text { Dado que as subunidades do } \\
\text { carboidrato são os } \\
\text { polissacarídeos, assim, os } \\
\text { carboidratos são } \\
\text { macromoléculas. }\end{array}$ \\
\hline \multirow[t]{5}{*}{7} & 51 & 182 & & $\mathrm{P}$ & Então eles estão em direções opostas, por isso, que foram chamadas de fitas antiparalelas. Certo? & $\begin{array}{l}\text { Dado que estão em direções } \\
\text { opostas, assim, foram chamadas } \\
\text { de fitas antiparalelas. }\end{array}$ \\
\hline & $5 \mathrm{II}$ & 190 & 00:00:14 & $\mathrm{P}$ & $\begin{array}{l}\text { Só que as duas fitas são antiparalelas, Então, se uma, se um está virado para lá, uma fileira, para lá, todo } \\
\text { mundo virado para lá. E essa fileira [a outra], virada para lá [aponta o lado oposto] }\end{array}$ & $\begin{array}{l}\text { Dado que as fitas são } \\
\text { antiparalelas, assim, se uma } \\
\text { fileira está virada para cá, todo } \\
\text { mundo vira pra lá, enquanto a } \\
\text { outra fileira vira para o outro } \\
\text { lado. }\end{array}$ \\
\hline & \multirow[t]{3}{*}{$5 \mathrm{I}$} & 215 & & & $\begin{array}{l}\text { Ou se, por exemplo, então eu vou ligar aqui com o João e vou fazer uma ligação certa. Se o João, o João é A, } \\
\text { ele é Adenina, certo? Então esse tem que ser o que? }\end{array}$ & \multirow[t]{3}{*}{$\begin{array}{l}\text { Dado que o João é adenina, } \\
\text { assim, esse tem que ser T. }\end{array}$} \\
\hline & & 216 & & A & Adenina & \\
\hline & & 217 & & A & $T$ & \\
\hline \multirow[t]{2}{*}{8} & \multirow[t]{2}{*}{711} & 17 & 00:03:59 & $P$ & $\begin{array}{l}\text { Cromatina. Então fios de DNA enrolados nas proteínas, mas eles estão um pouco mais esticados, certo? Se } \\
\text { eles estão na mitose, na divisão celular propriamente dita, eles são chamados de? }\end{array}$ & \multirow{2}{*}{$\begin{array}{l}\text { Dado que a célula está na mitose, } \\
\text { que é a divisão propriamente } \\
\text { dita, assim, os fios são chamados } \\
\text { de cromossomos. }\end{array}$} \\
\hline & & 18 & $00: 04: 14$ & $A$ & Cromossomos. & \\
\hline Categoria & Aula & Linha & Tempo & Pessoa & Fala & Argumento \\
\hline \multirow[t]{2}{*}{9} & \multirow[t]{2}{*}{711} & \multirow[t]{2}{*}{64} & \multirow[t]{2}{*}{$00: 15: 37$} & \multirow[t]{2}{*}{$P$} & \multirow[t]{2}{*}{$\begin{array}{l}\text { Eles sabiam que existiam duas linhagens dessa espécie de bactérias, de Streptococcus. A linhagem S e a } \\
\text { linhagem R, está aí na ficha de vocês. E a linhagem S produz uma cápsula de carboidrato e causa pneumonia } \\
\text { em camundongos. E a linhagem R não produz essa cápsula e não causa a pneumonia em camundongos. } \\
\text { Então, provavelmente esta cápsula está ligada com a sobrevivência da bactéria no corpo do indivíduo, do } \\
\text { camundongo. Se ela tem essa cápsula, ela fica mais resistente lá, né? Às células de defesa do camundongo e } \\
\text { acaba se reproduzindo causando um dano no organismo do hospedeiro, certo, causando a doença. }\end{array}$} & $\begin{array}{l}\text { Dado que a linhagem S produz } \\
\text { uma cápsula de carboidrato e } \\
\text { causa pneumonia em } \\
\text { camundongos. E a linhagem R } \\
\text { não produz essa cápsula e não } \\
\text { causa a pneumonia em } \\
\text { camundongos, assim, } \\
\text { provavelmente, esta cápsula está } \\
\text { ligada com a sobrevivência da } \\
\text { bactéria no corpo do indivíduo. }\end{array}$ \\
\hline & & & & & & $\begin{array}{l}\text { Dado que se ela tem essa cápsula } \\
\text { é mais resistente às células de } \\
\text { defesa do camundongo, assim, } \\
\text { acaba se reproduzindo e } \\
\text { causando um dano no organismo }\end{array}$ \\
\hline
\end{tabular}




\begin{tabular}{|c|c|c|c|c|c|}
\hline & & & & & do hospedeiro. \\
\hline 7 & 65 & $00: 16: 22$ & $P$ & $\begin{array}{l}\text { Se ela não tem aquela cápsula de carboidratos, então ela fica mais vulnerável ao ataque, por exemplo, né, } \\
\text { das células de defesa lá do camundongo, que conseguem matá-la que acaba não se reproduzindo e não } \\
\text { causando a doença no camundongo. Certo? }\end{array}$ & $\begin{array}{l}\text { Dado que se ela não tem aquela } \\
\text { cápsula de carboidratos ela fica } \\
\text { mais vulnerável ao ataque das } \\
\text { células de defesa do } \\
\text { camundongo, assim, não causa a } \\
\text { doença no camundongo. }\end{array}$ \\
\hline \multirow[t]{2}{*}{71} & \multirow[t]{2}{*}{100} & \multirow[t]{2}{*}{$00: 24: 13$} & \multirow[t]{2}{*}{$\mathrm{P}$} & \multirow{2}{*}{$\begin{array}{l}\text { Então a S viva consegue se reproduzir no corpo do indivíduo, certo? Por quê? Porque ela não tem lá aquela } \\
\text { cápsula de carboidrato? Então ela vai, se reproduz, causa uma pneumonia muito forte, então atinge os } \\
\text { pulmões e pode até causar a morte do rato. Certo? A R nãa. Por que é que não? Por que ela não tem aquela } \\
\text { cápsula e ela consegue ser morta pelos (...) pelas célulalas de defesa do próprio rato antes de se reproduzir e } \\
\text { destruir os tecidos do pulmão. Só que a S morta pelo calor, nós matamos a bactéria, oh pessoal, acompanha } \\
\text { o raciocínio aqui João. }\end{array}$} & $\begin{array}{l}\text { Dado que a Bactéria } S \text { viva tem } \\
\text { aquela cápsula de carboidrato, } \\
\text { assim, ela consegue se reproduzir } \\
\text { no corpo do indivíduo. }\end{array}$ \\
\hline & & & & & $\begin{array}{l}\text { Dado que a bactéria R não tem } \\
\text { aquela cápsula, assim, é morta } \\
\text { pelas células de defesa do rato } \\
\text { antes de se reproduzir e destruir } \\
\text { os tecidos do pulmão. }\end{array}$ \\
\hline \multirow[t]{3}{*}{8} & \multirow[t]{3}{*}{44} & \multirow[t]{3}{*}{ 01:41:15 } & \multirow[t]{3}{*}{$\mathrm{b}$} & \multirow{3}{*}{$\begin{array}{l}\text { Elas têm uma cápsula de carboidrato em volta delas, por isso é que elas causam pneumonia. Por que como } \\
\text { elas são resistentes por causa dessa capa, essa cápsula acaba servindo como proteção. Que vai fazer com q } \\
\text { ela seja mais resistente no corpo do camundongo. As células do camundongo não conseguem destruir a } \\
\text { bactéria q tem essa á́psula. Por isso é: quem tem a cápsula é que consegue se reproduzir no corpo do } \\
\text { camundongo, causando a pneumonia, os sintomas da pneumonia, certo? }\end{array}$} & $\begin{array}{l}\text { Dado que elas [as bactérias } \mathrm{S} \text { ] } \\
\text { têm uma cápsula de carboidrato } \\
\text { em volta delas, assim, elas } \\
\text { causam pneumonia. }\end{array}$ \\
\hline & & & & & $\begin{array}{l}\text { Dado que elas têm essa cápsula, } \\
\text { assim, a cápsula serve de } \\
\text { proteção. }\end{array}$ \\
\hline & & & & & $\begin{array}{l}\text { Dado que as células do } \\
\text { camundongo não conseguem } \\
\text { destruir a bactéria, já que a } \\
\text { bactéria tem essa cápsula, assim, } \\
\text { as bactérias que tem cápsula } \\
\text { conseguem se reproduzir no } \\
\text { corpo do camundongo, causando } \\
\text { pneumonia. }\end{array}$ \\
\hline
\end{tabular}




\begin{tabular}{|c|c|c|c|c|c|c|}
\hline Categoria & Aula & Linha & Tempo & Pessoa & Fala & Argumento \\
\hline \multirow[t]{12}{*}{10} & \multirow[t]{2}{*}{51} & 260 & & $P$ & $\begin{array}{l}\text { Mas o que é que ele fez? Ele pegou aqui e inoculou nos ratinhos ele inoculou bactérias } S \text { vivas, o que é que } \\
\text { aconteceu com o ratinho? }\end{array}$ & \multirow{2}{*}{$\begin{array}{l}\text { Dado que ele inoculou os } \\
\text { ratinhos com bactérias } S \text { vivas, } \\
\text { assim, o ratinho morreu. }\end{array}$} \\
\hline & & 261 & & A & Morreu & \\
\hline & \multirow[t]{2}{*}{51} & 265 & & $\mathrm{P}$ & Aí ele pegou e inoculou com $\mathrm{R}$ vivas (inaudível), certo? O que é que aconteceu com o ratinho? & \multirow{2}{*}{$\begin{array}{l}\text { Dado que ele inoculou com } \mathrm{R} \\
\text { vivas, assim, nada aconteceu com } \\
\text { o ratinho. }\end{array}$} \\
\hline & & 266 & & A & Nada & \\
\hline & $7 \mid I$ & 77 & $00: 18: 37$ & $P$ & $\begin{array}{l}\text { Oh, não, gente, cobaias, tá? Camundongos criados aí pra experimentação, tá? Todos iguais, da mesma } \\
\text { linhagem também, pra não haver diferença dos resultados, tá? O que ele mudou aqui foi o que? Foi a forma } \\
\text { como as bactérias, né os tipos de bactérias inoculadas. Então, no primeiro grupo de camundongos ele coloca } \\
\text { as bactérias } S \text { vivas. A S, tá lá, causa pneumonia e causa a morte dos camundongos. Então ele inoculou } \\
\text { bactérias } S \text { vivas e os camundongos pegaram pneumonia e morreram. Aí ele pegou e testou também as R } \\
\text { vivas, pegou bactérias R vivas. OW João, senta direito. }\end{array}$ & $\begin{array}{l}\text { Dado que ele inoculou bactérias } S \\
\text { vivas, já que a } S \text { causa } \\
\text { pneumonia e causa a morte dos } \\
\text { camundongos, assim, os } \\
\text { camundongos pegaram } \\
\text { pneumonia e morreram. }\end{array}$ \\
\hline & \multirow[t]{4}{*}{$7 \mathrm{II}$} & 79 & $00: 19: 38$ & $\mathrm{P}$ & Inoculou, Shh bactérias R vivas no camundongo e o que é que aconteceu? & $\begin{array}{l}\text { Dado que inoculou bactérias } R \\
\text { vivas no camundongo, já que as } R \\
\text { não causam pneumonia, assim, o } \\
\text { camundongo sobreviveu. }\end{array}$ \\
\hline & & 80 & $00: 19: 47$ & $P$ & $\begin{array}{l}\text { Sobreviveu. As R não causam pneumonia e aí eles sobreviveram felizes da vida, né? Não foi dessa vez que } \\
\text { eles morreram. O outro grupo de camundongos ele pegou as bactérias } \mathrm{S} \text { matou as bactérias com calor, } \\
\text { certo? Então ele matou as bactérias. E inoculou essas bactérias mortas pelo calor nos camundongos e aí o } \\
\text { que a gente espera que acontecesse? }\end{array}$ & $\begin{array}{l}\text { Dado que inoculou essas } \\
\text { bactérias mortas pelo calor nos } \\
\text { camundongos, assim, os } \\
\text { camundongos sobreviveram. }\end{array}$ \\
\hline & & 81 & $00: 20: 20$ & $P$ & Sobrevivessem. & \\
\hline & & 82 & $00: 20: 21$ & $P$ & $\begin{array}{l}\text { Que eles sobrevivessem. As bactérias S estão mortas e realmente foi isso o que aconteceu. Eles } \\
\text { sobreviverem, certo? }\end{array}$ & \\
\hline & \multirow[t]{2}{*}{$7 \mathrm{II}$} & 83 & $00: 20: 30$ & $P$ & $\begin{array}{l}\text { E, depois, o que é que ele fez? Vejam: ele pegou bactérias } \mathrm{S} \text { mortas pelo calor mais } \mathrm{R} \text { vivas. } \mathrm{S} \text { mortas: } \\
\text { ratinho sobrevive, R vivas: ratinho sobrevive. O que é que então, ele esperarei que acontecesse aqui? Que } \\
\text { eles sobrevivessem, mas o que é que aconteceu? }\end{array}$ & \multirow{2}{*}{$\begin{array}{l}\text { Dado que ele pegou bactérias } S \\
\text { mortas pelo calor mais } R \text { vivas, já } \\
\text { que } S \text { mortas: ratinho sobrevive, } \\
\text { R vivas: ratinho sobrevive, assim, } \\
\text { esperava-se que os ratinhos } \\
\text { sobrevivessem. }\end{array}$} \\
\hline & & 84 & $00: 20: 59$ & $P$ & Morreu & \\
\hline & 81 & 20 & $00: 00: 45$ & A & $\begin{array}{l}\text { Podemos afirmar que o DNA é o portador das informações hereditárias porque no primeiro experimento } \\
\text { quando foi colocada a bactéria que causava a doença morta e a que não causava viva, esperava-se que o } \\
\text { ratinho não morresse. Mas as informações hereditárias da bactéria morta passou para a outra bactéria. } \\
\text { Assim o DNA foi modificado e (inaudivel) igual ao da bactéria mãe. No segundo experimento concluiu-se que } \\
\text { o DNA é portador das informações pois encontraram fósforo radioativo dentro da bactéria, sendo que ele } \\
\text { havia sido colocado antes no DNA do vírus. O vírus se reproduziu e matou a bactéria. Observa-se que em } \\
\text { ambas as situações, foi por meio do DNA que houve as mudanças, concluindo que as informações } \\
\text { (inaudível). }\end{array}$ & $\begin{array}{l}\text { Dado que no primeiro } \\
\text { experimento quando foi colocada } \\
\text { a bactéria que causava a doença } \\
\text { morta e a que não causava viva, } \\
\text { esperava-se que o ratinho não } \\
\text { morresse, assim, Podemos } \\
\text { afirmar que o DNA é o portador } \\
\text { das informações hereditárias. }\end{array}$ \\
\hline
\end{tabular}




\begin{tabular}{|c|c|c|c|c|c|c|}
\hline & & & & & & $\begin{array}{l}\text { Dado que encontraram fósforo } \\
\text { radioativo dentro da bactéria, } \\
\text { sendo que ele havia sido } \\
\text { colocado antes no DNA do vírus, } \\
\text { assim, No segundo experimento } \\
\text { concluiu-se que o DNA é } \\
\text { portador das informações. }\end{array}$ \\
\hline Categoria & Aula & Linha & Tempo & Pessoa & Fala & Argumento \\
\hline 11 & $7 \mathrm{II}$ & 99 & $00: 23: 14$ & $P$ & $\begin{array}{l}\text { Não, não. Isso aqui é um outro ser vivo, não tem nada a ver. Na verdade, o que é que acontece? Pessoal! É } \\
\text { (...) por que é que elas causam pneumonia. Por que é que a S causa pneumonia? Ela se instala ali nas células } \\
\text { do sistema respiratório e vai se reproduzindo, a bactéria. E aí, para, nesta reprodução, ela vai aí destruindo } \\
\text { aí as células saudáveis do indivíduo, então não tem nada a ver com gripe aqui. Isso é um outro ser vivo, elas } \\
\text { mesmas, pela sua reprodução elas vão infectando o organismo, aquele (inaudível), vão pegando todos os } \\
\text { nutrientes do ambiente, né? E a células do próprio indivíduo vão morrendo tá? Então isso seria a doença, } \\
\text { tá? }\end{array}$ & $\begin{array}{l}\text { Dado que a bactéria S se instala } \\
\text { ali nas células do sistema } \\
\text { respiratório e vai se } \\
\text { reproduzindo, a bactéria. E aí, } \\
\text { para, nesta reprodução, ela vai aí } \\
\text { destruindo aí as células saudáveis } \\
\text { do indivíduo, assim, ela causa } \\
\text { pneumonia. }\end{array}$ \\
\hline 12 & $7 \mathrm{ll}$ & 111 & $00: 26: 41$ & $P$ & $\begin{array}{l}\text { O princípio, como eles chamam aí de transformação bacteriana. Porque a bactéria } \mathrm{R} \text { foi transformada em } \\
\text { bactéria S. Então, em contato, sozinho? Do nada? Não. Em contato com as bactérias } \mathrm{S} \text { mortas. Então alguma } \\
\text { coisa da } \mathrm{S} \text { morta, algum princípio transformante, (inaudível) genérico porque eles não sabiam o que era esse } \\
\text { princípio transformante. Foi incorporado pela R e a R viva se transformou em S. Certo? }\end{array}$ & $\begin{array}{l}\text { Dado que a bactéria } \mathrm{R} \text { foi } \\
\text { transformada em } \mathrm{S} \text {, assim, eles } \\
\text { chamam de transformação } \\
\text { bacteriana. }\end{array}$ \\
\hline \multirow[t]{9}{*}{13} & \multirow[t]{3}{*}{51} & 341 & & & $\begin{array}{l}\text { Que a amilase vai destruir o amido. Então, se for amido. Se quando eu pegar esse princípio e juntar com } \\
\text { bactérias } R \text {, a bactéria } R \text { vai se transformar em } S \text { ? }\end{array}$ & \multirow{3}{*}{$\begin{array}{l}\text { Dado que ao colocar amilase a } \\
\text { bactéria R se transformou em } \mathrm{S} \text {, } \\
\text { já que a amilase destrói amido o } \\
\text { princípio podia ser amido. Assim, } \\
\text { o princípio transformante não é } \\
\text { amido. }\end{array}$} \\
\hline & & 342 & & & Se for amido? & \\
\hline & & 344 & & $\mathrm{P}$ & $\begin{array}{l}\text { Mas o que é que ele fez? Ele colocou a amilase, colocou na bactéria } \mathrm{R} \text {, só que a bactéria } \mathrm{R} \text { se transformou } \\
\text { em S. É amido? }\end{array}$ & \\
\hline & \multirow[t]{2}{*}{51} & 349 & & $P$ & Depois ele colocou proteases. Proteases são enzimas que digerem o quê? & \multirow{2}{*}{$\begin{array}{l}\text { Dado que ao colocar protease o } \\
\text { princípio transformante } \\
\text { continuou ativo, assim, o } \\
\text { princípio transformante não é } \\
\text { protease. }\end{array}$} \\
\hline & & 353 & & & $\begin{array}{l}\text { É (...) continuou com o princípio transformante, ou seja, se eu pegar isso daqui, juntas com bactérias R elas } \\
\text { vão se transformar em S. São proteínas? }\end{array}$ & \\
\hline & \multirow[t]{2}{*}{51} & 354 & & $P$ & $\begin{array}{l}\text { Não. Se ele colocou lá num outro tubo de ensaio, um outro princípio transformante com ribonucleases. } \\
\text { Ribonucleases digerem o que? }\end{array}$ & \multirow{2}{*}{$\begin{array}{l}\text { Dado que após tratar com } \\
\text { ribonuclease juntou as Bactérias } \\
\text { R e elas se transformaram em S, } \\
\text { assim, não é RNA. }\end{array}$} \\
\hline & & 357 & & & $\begin{array}{l}\text { Ribonuclease digere ribose, quem é formado por ribose é o RNA, tá? Ãh (...) Juntou com bactérias R, essas } \mathrm{R} \\
\text { se transformaram em S. É RNA? }\end{array}$ & \\
\hline & \multirow[t]{2}{*}{51} & 360 & & $P$ & $\begin{array}{l}\text { Colocou o princípio transformante com desoxirribose. Desoxirribonucleases. Desoxirribonucleases são } \\
\text { enzimas que digerem? }\end{array}$ & \multirow{2}{*}{$\begin{array}{l}\text { Dado que ao colocar o princípio } \\
\text { transformante com } \\
\text { desoxirribonuclease as bactérias } \\
\text { continuaram } R \text {, assim, a }\end{array}$} \\
\hline & & 361 & & $P$ & $\begin{array}{l}\text { DNA, certo? Então quebram e cortam o DNA. Pegou esse princípio agora, colocou com bactérias R. O que é } \\
\text { que aconteceu? }\end{array}$ & \\
\hline
\end{tabular}




\begin{tabular}{|c|c|c|c|c|c|}
\hline & 362 & & & Elas continuaram $\mathrm{R}$. & \multirow{3}{*}{$\begin{array}{l}\text { substância transformante é o } \\
\text { DNA. }\end{array}$} \\
\hline & 365 & & & O que é que era o princípio transformante? & \\
\hline & 368 & & & $\begin{array}{l}\text { Então, a substância transformante é o DNA. Agora, ãh (...) eu quero que vocês me respondam a seguinte } \\
\text { pergunta. Para a próxima aula. Tá, então vejam gente. Uma coisa específica, um experimento específico } \\
\text { que, de transformação bacteriana. Que mostrou que o princípio transformante, que faz transformar } \\
\text { bactérias R em S é o DNA. Por que é que isso foi um experimento que demonstra que o DNA é o material } \\
\text { que contém as informações hereditárias? }\end{array}$ & \\
\hline \multirow[t]{3}{*}{81} & 30 & 00:03:18 & $P$ & A capacidade de causar doença. Onde estava essa capacidade? & \multirow{3}{*}{$\begin{array}{l}\text { Dado que eles separaram o } \\
\text { princípio transformante e viram } \\
\text { que esse princípio era feito de } \\
\text { DNA, assim, a capacidade de } \\
\text { causar doença estava no DNA. }\end{array}$} \\
\hline & 31 & 00:03:22 & A & No DNA & \\
\hline & 32 & 00:03:23 & $\mathrm{P}$ & $\begin{array}{l}\text { No DNA, porque eles separaram lá o princípio transformante e viram que esse princípio era feito de DNA. } \\
\text { Então as bactérias, elas tem essa capacidade, são os únicos seres vivos que têm essa capacidade, então } \\
\text { aquelas que estão no meio de um monte de bactérias, essa que tem a capacidade de pegar o DNA de outra } \\
\text { bactéria, não é? Nós não (...) }\end{array}$ & \\
\hline \multirow[t]{3}{*}{711} & 136 & 00:33:10 & $P$ & $\begin{array}{l}\text { Então se o princípio transformante fosse amido, amilase iria quebrar esse princípio transformante, ele iria } \\
\text { continuar como princípio transformante? Não ele ia ser destruído. Certo? O que é que aconteceu aí? O que } \\
\text { é que está escrito aí no texto? Ele continua como princípio transformante. É amido? }\end{array}$ & \multirow{3}{*}{$\begin{array}{l}\text { Dado que se o princípio } \\
\text { transformante fosse amido, } \\
\text { amilase iria quebrar esse } \\
\text { princípio transformante e ele não } \\
\text { continuaria agindo como } \\
\text { princípio transformante, assim, o } \\
\text { princípio transformante não é } \\
\text { amido. }\end{array}$} \\
\hline & 137 & 00:33:32 & A & Não. & \\
\hline & 138 & 00:33:33 & $\mathrm{P}$ & Não. & \\
\hline \multirow[t]{3}{*}{$7 \|$} & 139 & 00:33:34 & $P$ & Nesse princípio transformante foi acrescentado protease. Proteases são enzimas que digerem? & \multirow{3}{*}{$\begin{array}{l}\text { Dado que nesse princípio } \\
\text { transformante foi acrescentado } \\
\text { protease e continuou sendo o } \\
\text { princípio transformante, já que } \\
\text { proteases são enzimas que } \\
\text { digerem proteínas, assim, não é } \\
\text { proteína. }\end{array}$} \\
\hline & 140 & 00:33:44 & A & Proteínas & \\
\hline & 141 & 00:33:45 & $P$ & Proteínas. O que é que aconteceu? Continuou como princípio transformante, são proteínas? & \\
\hline \multirow[t]{6}{*}{ 7II } & 142 & 00:33:53 & $\mathrm{P}$ & Não. Ribonucleases. Ribonucleases são enzimas que digerem. & \multirow{6}{*}{$\begin{array}{l}\text { Dado que adicionou ribonuclease } \\
\text { e continuou com o princípio } \\
\text { transformante, já que } \\
\text { Ribonucleases são enzimas que } \\
\text { digerem RNA, assim, não é RNA. }\end{array}$} \\
\hline & 143 & 00:33:59 & A & Ribonucleicos & \\
\hline & 144 & 00:34:00 & $\mathrm{P}$ & Ribonucleicos, o que é que é ribonucleico? RNA, muito bem. Então. & \\
\hline & 145 & 00:34:08 & $P$ & Então, ribonucleases continuou com o princípio transformante? & \\
\hline & 146 & 00:34:13 & A & Sim & \\
\hline & 147 & 00:34:14 & $P$ & Sim. É RNA? Não & \\
\hline \multirow[t]{2}{*}{$7 \|$} & 148 & 00:34:17 & $P$ & $\begin{array}{l}\text { Desoxirribonuclease. Enzima que digere o DNA, então quebra o DNA. Perdeu o princípio transformante. } \\
\text { Então o princípio transformante é o quê? }\end{array}$ & \multirow{2}{*}{$\begin{array}{l}\text { Dado que a adiç̃a de } \\
\text { Desoxirribonuclease fez perder o } \\
\text { princípio transformante, já que } \\
\text { desoxirribonuclease é a enzima }\end{array}$} \\
\hline & 149 & 00:34:30 & A & DNA & \\
\hline
\end{tabular}




\begin{tabular}{|c|c|c|c|c|c|c|}
\hline & & & & & & $\begin{array}{l}\text { que digere o DNA, assim, o } \\
\text { princípio transformante é o DNA. }\end{array}$ \\
\hline Categoria & Aula & Linha & Tempo & Pessoa & Fala & Argumento \\
\hline \multirow[t]{3}{*}{14} & 71 & 91 & $00: 17: 25$ & $P$ & $\begin{array}{l}\text { Ele tem apenas essa cápsula proteica, uma cápsula de proteínas, e ele tem DNA no seu interior. Existem } \\
\text { vírus de RNA também, mas esse vírus bacteriófago ele é um vírus de DNA, certo? }\end{array}$ & \multirow{2}{*}{$\begin{array}{l}\text { Dado que o vírus tem uma } \\
\text { estrutura tão simples, já que é } \\
\text { formado por uma cápsula de } \\
\text { proteínas e o DNA no seu } \\
\text { interior, assim, há uma discussão } \\
\text { se ele é um ser vivo ou não. }\end{array}$} \\
\hline & & 92 & $00: 17: 45$ & $P$ & $\begin{array}{l}\text { Tanto é que é uma estrutura tão simples que há uma discussão se ele é um ser vivo ou não. Porque se a } \\
\text { gente considerar que o vírus é um ser vivo, que ele é formado de célula (inaudível) ter enzimas, que } \\
\text { realizam reações químicas. O vírus não tem nada disso. (inaudível) pode ser considerado um ser vivo ou não. } \\
\text { Mas isso é uma outra discussão. }\end{array}$ & \\
\hline & 711 & 161 & $00: 36: 43$ & $P$ & $\begin{array}{l}\text { Inclusive a discussão se vírus é ser vivo ou não porque ele não tem mais nenhuma outra organela celular. } \\
\text { Então ele não tem membrana plasmática, ele não tem núcleo, ele não tem citoplasma ele não tem é (...) } \\
\text { retículo endoplasmático, ele não tem mitocôndria, ele não tem absolutamente nada. Só tem DNA e essa } \\
\text { cápsula protéica. Certo? }\end{array}$ & $\begin{array}{l}\text { Dado que o vírus não tem } \\
\text { nenhuma outra organela células, } \\
\text { já que ele não tem membrana } \\
\text { plasmática, ele não tem núcleo, } \\
\text { ele não tem citoplasma ele não } \\
\text { tem é (...) retículo } \\
\text { endoplasmático, ele não tem } \\
\text { mitocôndria, ele não tem } \\
\text { absolutamente nada. Só tem } \\
\text { DNA e essa cápsula protéica, } \\
\text { assim, há uma discussão sobre } \\
\text { vírus ser um ser vivo ou não. }\end{array}$ \\
\hline 15 & 711 & 162 & $00: 37: 07$ & $P$ & $\begin{array}{l}\text { E como ele faz? Ah (...) sabia-se que o vírus infecta a bactéria, então coloca alguma coisa dentro da bactéria. } \\
\text { Esta coisa que ele coloca, que ou é o DNA ou são as proteínas, tem informação pra ele construir novos vírus, } \\
\text { Ele constrói centenas de vírus novos e a bactéria, a célula explode. Certo? Então ele usa todo o mecanismo } \\
\text { da célula da bactéria para sua reprodução, porque ele não tem nada lá dentro, só o DNA. Né? Então ele usa } \\
\text { toda a estrutura da bactéria para a sua reprodução e até que a célula, até que ele produz centenas aí de } \\
\text { vírus e explode, liberando outros vírus que vão infectar novas bactérias e assim é o modo de funcionamento } \\
\text { do vírus, tá? Inclusive nas nossas células, nos vírus que infectam a gente. Tá? }\end{array}$ & $\begin{array}{l}\text { Dado que o vírus não tem nada lá } \\
\text { dentro, só o DNA, assim, ele usa } \\
\text { todo o mecanismo da célula da } \\
\text { bactéria para sua reprodução. }\end{array}$ \\
\hline
\end{tabular}




\begin{tabular}{|c|c|c|c|c|c|c|}
\hline Categoria & Aula & Linha & Tempo & Pessoa & Fala & Argumento \\
\hline \multirow[t]{3}{*}{16} & 711 & 164 & $00: 38: 25$ & $P$ & $\begin{array}{l}\text { Então, o que é que eles fizeram aí em 1952? Eles marcaram o DNA com fósforo radioativo. Porque o DNA } \\
\text { tem fósforo, não tem? Então eles marcaram o DNA com fósforo radioativo. Por quê? A radioatividade é } \\
\text { usada nos laboratórios, né, de biologia molecular porque ela emite luz, então você consegue identificar as } \\
\text { substâncias aí, certo? Onde é que estão, pra onde foram e tal. Então foi marcado com fósforo radioativo. E a } \\
\text { proteína tem enxofre e não tem fosforo, foi marcada com enxofre radioativo. }\end{array}$ & $\begin{array}{l}\text { Dado que a radioatividade é } \\
\text { usada nos laboratórios de } \\
\text { biologia molecular porque ela } \\
\text { emite luz, então você consegue } \\
\text { identificar as substâncias, assim, } \\
\text { marcaram o DNA com fósforo } \\
\text { radioativo. }\end{array}$ \\
\hline & 711 & 165 & $00: 39: 25$ & $P$ & $\begin{array}{l}\text { Porque assim, marcando, eles poderiam ver o que é que entra na célula da bactéria. E aí o que é que eles } \\
\text { encontraram? Eles encontraram, dentro da célula da bactéria, o fósforo radioativo. Então eles encontraram } \\
\text { o fósforo radioativo. Conclusão: o que é que entra na célula? }\end{array}$ & $\begin{array}{l}\text { Dado que se marcassem, assim, } \\
\text { poderiam ver o que é que entra } \\
\text { na célula da bactéria. }\end{array}$ \\
\hline & 71 & 117 & & $P$ & $\begin{array}{l}\text { Eles marcaram com substâncias radioativas a proteína e o DNA do vírus. Por que é que eles marcaram com } \\
\text { substâncias radioativas? As substâncias radioativas emitem radioatividade e isso pode ser detectado, né? }\end{array}$ & $\begin{array}{l}\text { Dado que eles marcaram a } \\
\text { proteína e o DNA do vírus com } \\
\text { substâncias radioativas, assim, } \\
\text { podem ser detectadas. }\end{array}$ \\
\hline 17 & 811 & 19 & 01:36:34 & A & $\begin{array}{l}\text { A gente conversou e a gente achou (...) não (...) nos dois experimentos eles chegavam (inaudível) que várias } \\
\text { substâncias que podem ser supostas (...) que podem conter o material genético e aí eles chegam sempre ao } \\
\text { mesmo resultado, que é o único que pode ser o material genético é o DNA (...) tipo, por exclusão mesmo, } \\
\text { né? }\end{array}$ & $\begin{array}{l}\text { Dado que excluímos as outras } \\
\text { substâncias, assim, o único que } \\
\text { pode ser o material genético é o } \\
\text { DNA. }\end{array}$ \\
\hline \multirow[t]{3}{*}{18} & 51 & 140 & & $\mathrm{P}$ & $\begin{array}{l}\text { Ele verificou que a composição de bases varia de espécie para espécie, então se eu pegar uma célula } \\
\text { humana eu tenho um determinado número de bases nitrogenadas. Se eu pegar uma célula de um rato, eu } \\
\text { tenho outro número de bases nitrogenadas. E assim por diante, certo? Então }\end{array}$ & $\begin{array}{l}\text { Dado que a composição de bases } \\
\text { varia de espécie para espécie, } \\
\text { assim, se eu pegar uma célula } \\
\text { humana eu tenho um } \\
\text { determinado número de bases e } \\
\text { se eu pegar uma célula de um } \\
\text { rato, eu tenho outro número de } \\
\text { bases, assim por diante. }\end{array}$ \\
\hline & \multirow[t]{2}{*}{51} & 141 & & $P$ & Então ele chegou nessa conclusão. & \multirow[b]{2}{*}{$\begin{array}{l}\text { Dado que a proporção de bases é } \\
\text { constante dentro da espécie, } \\
\text { assim, se eu pegar diferentes } \\
\text { órgãos ou diferentes células de } \\
\text { vários indivíduos da mesma } \\
\text { espécie, o número de bases é o } \\
\text { mesmo. }\end{array}$} \\
\hline & & 142 & & $P$ & $\begin{array}{l}\text { Outra conclusão que ele chegou, a proporção de bases é constante dentro da espécie. Então se eu pegar } \\
\text { diferentes órgãos diferentes células, de vários indivíduos da mesma espécie, o número de bases é o mesmo. } \\
\text { Então se eu pegar aí, de um indivíduo, meu coração, meu olho, meu pé, a minha pele, meu estômago vai ter } \\
\text { o mesmo número de bases nitrogenadas. Certo? }\end{array}$ & \\
\hline Categoria & Aula & Linha & Tempo & Pessoa & Fala & Argumento \\
\hline \multirow[t]{2}{*}{19} & \multirow[t]{2}{*}{71} & 79 & $00: 14: 41$ & $P$ & Além disso, foi feito um outro experimento. (inaudível) vírus bacteriófagos. O que são vírus bacteriófagos? & \multirow{2}{*}{$\begin{array}{l}\text { Dado que vírus bacteriófagos são } \\
\text { aqueles que atacam bactérias, } \\
\text { assim, bactérias também são } \\
\text { atacadas por vírus. }\end{array}$} \\
\hline & & 80 & & $\mathrm{P}$ & $\begin{array}{l}\text { Bacteriófago é o nome do vírus. Vírus bacteriófagos são aqueles que atacam bactérias. Então bactérias } \\
\text { também são atacadas por vírus, tá? }\end{array}$ & \\
\hline
\end{tabular}




\begin{tabular}{|c|c|c|c|c|c|c|}
\hline 20 & 81 & 40 & $00: 04: 56$ & $P$ & $\begin{array}{l}\text { É (...) as bactérias (...) a gente falou o ser humano e outros seres vivos. Como é que a informação passa para } \\
\text { outro ser vivo? Por meio (...) vocês responderam, por meio da reprodução, junta o espermatozoide, junta o } \\
\text { óvulo, se juntam, formam a primeira célula do indivíduo, certo? E aí, então, nós temos um novo indivíduo, } \\
\text { informação que gera um novo indivíduo. Então, da onde vem a informação que gera um novo indivíduo? } \\
\text { Dos gametas. Então das células sexuais, espermatozoide do macho, óvulo da fêmea, certo? As bactérias, } \\
\text { elas se reproduzem por reprodução assexuada, então elas se dividem em duas. Quando elas se dividem em } \\
\text { duas, a informação dessas duas são idênticas à informação da célula-mãe, da bactéria mãe. Certo, ok? }\end{array}$ & $\begin{array}{l}\text { Dado que junta o } \\
\text { espermatozoide, junta o óvulo, } \\
\text { se juntam, formam a primeira } \\
\text { célula do indivíduo, assim, a } \\
\text { informação que gera um novo } \\
\text { indivíduo vem dos gametas. }\end{array}$ \\
\hline 21 & 81 & 47 & $00: 06: 36$ & $P$ & $\begin{array}{l}\text { Então, as bactérias elas tem essa capacidade, inclusive foi essa capacidade, lá na origem da vida, que } \\
\text { permitiu a diversidade de seres vivos, por quê? Passando o DNA de uma pra outra, ela vai adquirir as } \\
\text { características daquele outro DNA. No caso da bactéria que causa pneumonia, a bactéria que não causa } \\
\text { pneumonia pegou o DNA da outra, e agora passou a ter essa característica. Causar a pneumonia, certo? }\end{array}$ & $\begin{array}{l}\text { Dado que passando o DNA de } \\
\text { uma pra outra, ela vai adquirir as } \\
\text { características daquele outro } \\
\text { DNA, assim, essa capacidade, lá } \\
\text { na origem da vida, que permitiu a } \\
\text { diversidade de seres vivos. }\end{array}$ \\
\hline 22 & 81 & 72 & $00: 13: 02$ & $P$ & $\begin{array}{l}\text { Aí, qual era a informação importante aí, então, na verdade, ela adquiriu uma estrutura, que foi o DNA, } \\
\text { descobriram que foi o DNA pelos experimentos. Esse DNA o que é que ele fez? Duas coisas ele fez. Ele fez } \\
\text { uma coisa que a Maria colocou ali, ele provocou mudanças na própria bactéria, certo? Então ele determina } \\
\text { a característica Física da bactéria? Sim, né? Então isso é uma das conclusões que a gente pode tirar, o DNA } \\
\text { ele está associado com as características físicas ali da própria bactéria. }\end{array}$ & $\begin{array}{l}\text { Dado que o DNA provocou } \\
\text { mudanças na própria bactéria, } \\
\text { assim, ele está associado com as } \\
\text { características físicas da própria } \\
\text { bactéria. }\end{array}$ \\
\hline
\end{tabular}

\begin{tabular}{|c|c|c|c|c|c|c|}
\hline Categoria & Aula & Linha & Tempo & Pessoa & Fala & Argumento \\
\hline \multirow[t]{4}{*}{23} & \multirow[t]{4}{*}{81} & 73 & $00: 13: 40$ & $P$ & $\begin{array}{l}\text { Que outra coisa aconteceu. Se suas filhas, suas filhas estão lá. Na hora que ela se reproduziu, ela vai ter as } \\
\text { mesmas características da mãe. Com o novo DNA? }\end{array}$ & \multirow{4}{*}{$\begin{array}{l}\text { Dado que as bactérias filhas } \\
\text { pegaram o DNA que conferiu as } \\
\text { mesmas características da mãe, } \\
\text { assim, quem tem a informação } \\
\text { que passa de uma geração pra } \\
\text { outra é o DNA. }\end{array}$} \\
\hline & & 74 & $00: 13: 57$ & $P$ & $\begin{array}{l}\text { Sim. Por que é que eu posso concluir que é com o novo DNA ? Porque, não causou a pneumonia? E pra } \\
\text { causar a pneumonia eu tenho que ter muitas bactérias. Daquele mesmo tipo, né, certo? Então o que é que } \\
\text { eu posso admitir? Que, na reprodução, essas bactérias pegaram também aquele DNA, certo? Se pegaram } \\
\text { DNA que conferiu as mesmas características da mãe, então quem tem a informação que passa de uma } \\
\text { geração pra outra? }\end{array}$ & \\
\hline & & 75 & $00: 14: 29$ & A & (inaudível) & \\
\hline & & 76 & $00: 14: 30$ & $P$ & É o DNA, né? & \\
\hline \multirow[t]{2}{*}{24} & \multirow[t]{2}{*}{81} & 77 & $00: 14: 34$ & $P$ & $\begin{array}{l}\text { Já dá pra concluir que é o DNA. Assim como no caso do vírus. O que é que o experimento mostrou? Quem } \\
\text { entra na célula e tem a informação para construir novos virus? }\end{array}$ & \multirow{2}{*}{$\begin{array}{l}\text { Dado o experimento, assim, } \\
\text { quem entra na célula e tem a } \\
\text { informação para construir novos } \\
\text { vírus é o DNA. }\end{array}$} \\
\hline & & 78 & $00: 14: 48$ & $P$ & O DNA. & \\
\hline
\end{tabular}


Apêndice 05 - Relação entre argumentos fornecidos e produzidos

\begin{tabular}{|c|c|c|c|c|}
\hline Aluno & Argumento & $\begin{array}{l}\text { Categorias temáticas no } \\
\text { dado }\end{array}$ & $\begin{array}{l}\text { Categorias temáticas na } \\
\text { justificativa }\end{array}$ & Categorias temáticas na conclusão \\
\hline \multirow[t]{3}{*}{1} & $\mathrm{~A} 1$ & 10 & - & - \\
\hline & A2 & 16 & 16 & - \\
\hline & A3 & - & - & - \\
\hline \multirow[t]{3}{*}{2} & $\overline{\mathrm{A} 1}$ & $9 b, 10,12, A$ & - & - \\
\hline & A2 & 13 & 13 & 5 \\
\hline & A3 & - & - & - \\
\hline \multirow[t]{2}{*}{3} & A1 & - & $5,9 a, 12,13, A$ & - \\
\hline & A2 & - & - & - \\
\hline \multirow[t]{3}{*}{4} & A1 & - & - & - \\
\hline & $\mathrm{A} 2$ & - & - & 16 \\
\hline & A3 & - & - & - \\
\hline \multirow[t]{3}{*}{5} & A1 & - & $9 b, 10$ & - \\
\hline & $\mathrm{A} 2$ & 13 & 13 & - \\
\hline & A3 & - & - & - \\
\hline 6 & $\overline{\mathrm{A} 1}$ & 12 & - & - \\
\hline \multirow[t]{2}{*}{7} & A1 & 12 & 11 & - \\
\hline & A2 & 16 & - & - \\
\hline \multirow[t]{3}{*}{8} & $\overline{\mathrm{A} 1}$ & 3 & - & 3 \\
\hline & $\mathrm{A} 2$ & 16 & - & - \\
\hline & A3 & - & - & - \\
\hline \multirow[t]{4}{*}{9} & A1 & 12 & - & 12 \\
\hline & A2 & 12 & $9 b$ & - \\
\hline & A3 & 16 & 16 & - \\
\hline & A4 & - & - & - \\
\hline 10 & A1 & - & - & - \\
\hline \multirow[t]{2}{*}{11} & $\mathrm{~A} 1$ & - & 16 & - \\
\hline & A2 & - & - & - \\
\hline 12 & $\mathrm{~A} 1$ & 16 & - & - \\
\hline 13 & A1 & 10 & - & - \\
\hline \multirow[t]{2}{*}{14} & $\overline{\mathrm{A} 1}$ & $9 b$ & - & - \\
\hline & $\mathrm{A} 2$ & 10,13 & 12 & - \\
\hline \multirow[t]{3}{*}{15} & $\overline{\mathrm{A} 1}$ & 17 & 17 & 17 \\
\hline & $\mathrm{A} 2$ & - & - & 16 \\
\hline & $\mathrm{A} 3$ & - & - & - \\
\hline 17 & A1 & - & 10 & - \\
\hline \multirow[t]{4}{*}{18} & $\overline{\mathrm{A} 1}$ & 12 & - & - \\
\hline & $\mathrm{A} 2$ & - & - & - \\
\hline & A3 & 16 & - & - \\
\hline & A4 & - & - & - \\
\hline 20 & A1 & $5,9 b, 10,13$ & - & - \\
\hline 22 & $\mathrm{~A} 1$ & - & - & - \\
\hline 23 & A1 & - & - & - \\
\hline \multirow[t]{2}{*}{24} & $\overline{\mathrm{A} 1}$ & $5,9 b, 10$ & - & - \\
\hline & A2 & 12 & - & - \\
\hline 25 & A1 & - & - & - \\
\hline \multirow[t]{4}{*}{26} & $\mathrm{~A} 1$ & - & - & - \\
\hline & $\mathrm{A} 2$ & - & - & - \\
\hline & A3 & - & - & - \\
\hline & A4 & - & - & - \\
\hline 27 & $\overline{\mathrm{A} 1}$ & - & - & - \\
\hline
\end{tabular}




\begin{tabular}{llllll}
\hline $\mathbf{2 8}$ & A1 & - & - & - \\
& A2 & 5 & 5 & - \\
\hline $\mathbf{2 9}$ & A1 & 3 & - & - \\
& A2 & - & - & 3 \\
\hline $\mathbf{3 0}$ & A1 & - & - & - \\
\hline $\mathbf{3 1}$ & A1 & - & - & - \\
\hline $\mathbf{3 2}$ & A1 & - & 11,16 & - \\
& A2 & 16 & - & - \\
\hline $\mathbf{3 4}$ & A1 & - & - & - \\
\hline $\mathbf{3 5}$ & A1 & - & $9 \mathrm{~b}, 10$ & - \\
& A2 & - & - & - \\
\hline
\end{tabular}

